nown

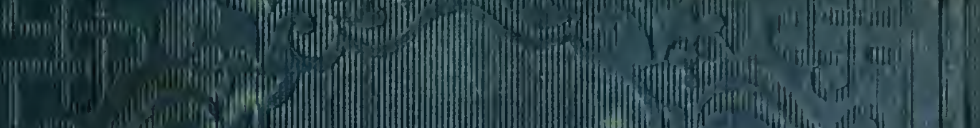

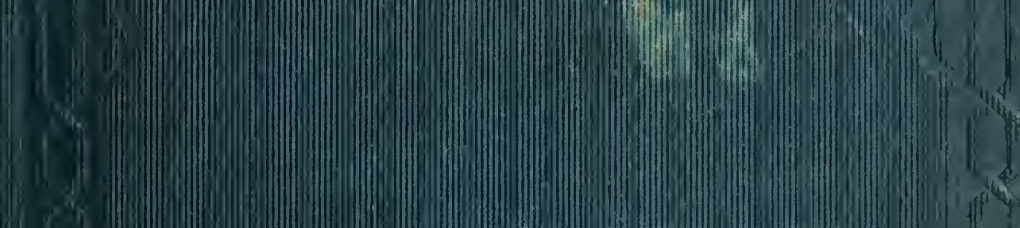

nia
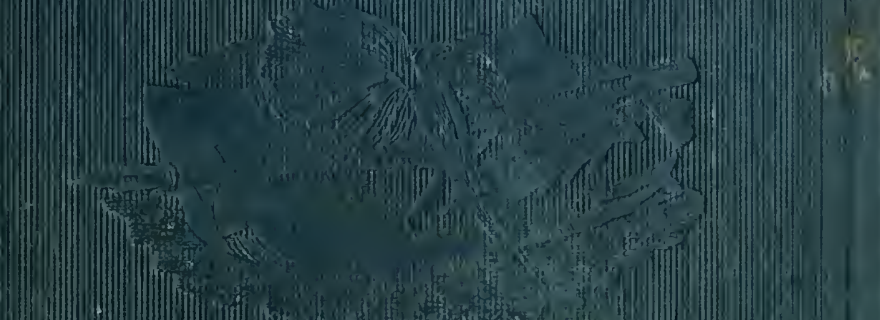

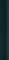

(.)
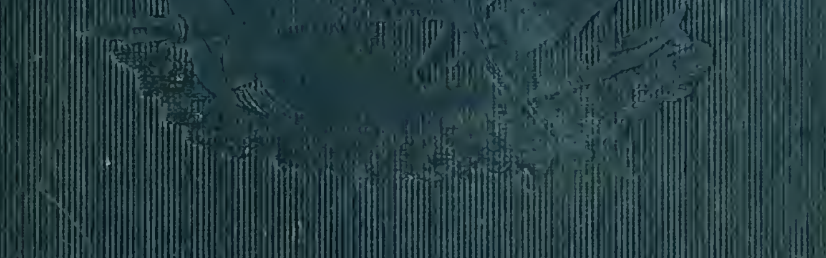


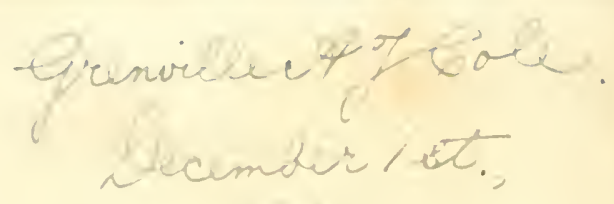
, 8fy. 




\title{
GEOLOGICAL EXCURSIONS
}

\author{
ROUND

\section{T H E I S L E 0 F W I G H T,}

AND ALONG THE

ADJACENT COAST OF DORSETSHIRE. 


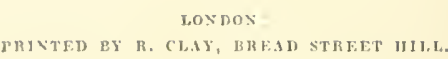




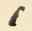 GEOLUGICAL EXCURSIONS \\ THE I S L E O F W I G H T, AND AIONO THE}

ADJACENT COAST OF DORSETSHIRE;

ILLTSTRATIVE OF IEE MOST

INTERESTING GEOLOGICAL PHENOMENA, AND ORGANIC REMAINS.

BY

GIDEON ALGERNON MLANTELL, ESQ. LL.D. F.R.S. A.TH.R OF "THE MFDAIS OF CRPATSON"

"THOUGHTS UN ANIBALCULES ?"

FTe.

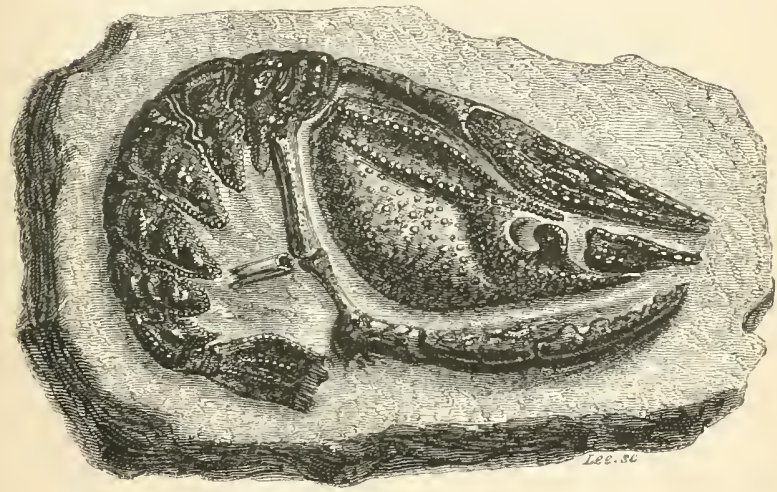

FOSAT, IOSSTET, FROR A R日RBPIELD.

"That brautiful Islant, which he is ho once sees neyer forgets, through whatever part of the wide world has tutare path may lear hias."

SiR WALTEY Scret's surgmon's Daughter,

\section{LONDON :}

HENRY G. BOHN, YORK STREET, COVENT GARDEN,

M D'CCXIVII. 



\section{HIS ROYAL HIGIINESS}

\section{PRINCE ALBERT,}

AS A TESTIMONX OF ADNIRATION AND RESPECT

FOT HIS ROYAL HIGHNESS'S

LIBERAL EXCOURAGEMENT OF BRITISH SCIENCE AND ART,

AND ARDENT SUPPORT OF EVERY ATTEMPT

TU AMELIORATE TIE CONDITION AND PROMOTE THE HAPPINESS

OF THE HUMAN RACE,

THESE UNPRETENDIYG PAGES

ARE, BY PEKMISSION, MOST RESPECTFULLY INSCRIBED,

BY HIS ROYAL HIGHNESS'S

HUUBLE AND DEVOTED SERVAXT,

GIDEON ALGERNON MANTELL.

CHR.STEL SQUAFE.

LoNens. 



\section{PRE F A CE.}

The Isce of Wight is described by Sir Walter Scott, as "that beautiful Island, which he who once sees, never forgets, through whatever part of the wide world his future path may lead him." And if this favoured spot deserve such an encomium from the Poet, and the ardent admirer of beautiful and picturesque scenery, it possesses stronger claims to the attention of the natural philosopher, for the strata of which it is composed, present phenomena of the highest interest, and abound in those "Medals of Creation," which elucidate some of the most important revolutions, recorded in the early pages of the earth's physical history.

The geological characters of the Isle of Wight are well known to the scientific inquirer, through the labours and publications of Sir IIenry Englefield, Mr. Thomas Welster, and other able observers; while the beautiful models of the stratification of 
the Undereliff, and sonthern coast, constructed by Cuptuin Ilbetson, and the collection of fossils accompanying them, which are exhibited in the Pulytechnic Institution of London, afford an instructive exposition of the strata and organic remains of this interesting clistrict.

But notwithstanding these admirable illustrations, l may renture to affirm, that the Geology of the fslancl is but little known or regarded by the majority of the intelligent persons, who ('very scason flock by thousands to its shores, and rapidly traversing the accustomed routes, visit the picturesque localities noted in the numerous handbooks, and take their departure, without suspecting that they have been travelling over a comitry, rich with the spoils of nature, and teeming with objects of the highest interest to the instructed observer.

liven the inhabitants, with but a few honourable execptions, manifest an extriordinary degree of anathy in every thing relating to the Geology of the Island. In vain will the stranger seck for jublic collections, illustrative of its physical structure, and fossil remains. In one week, it would be easy for a practical geologist to collect a more instructive serjen of specinens, than is contained 
in the Museum of the Scientific Institution of the capital of the Island-Newport.

Conceiving that this indifference and neglect may, in a great measure, be attributable to the want of a popular guide to the geological phenomena of the Island, for the well informed, but unscientific visitors, I have attempted to supply the deficiency in the present volume; which is designed to afford a familiar explanation of the physical structure of the Isle of Wight, and of the adjacent coast of Dorsetshire, and of the organic remains which abound in many of the localities that will come under our notice, in the course of these Excursions.

For the convenience of the geologist, and of others who may be desirous of investigating the stratification of the Island in detail, a list is subjoined of the principal works and memoirs hitherto published on the subject, and of which a general review is comprised in the following pages.

19, Chimster Square, Pimlico.

Jemuary, 1847. 
"If we look with wonder upon the great remains of human works, such as the columns of Palmyra, broken in the midst of the desert; the temples of l'istum, beautiful in the decay of twenty centuries: or the mutilated fragments of (ireek seulpture in the Acropolis of Athens, or in our own inuseums, a. proofs of the genius of artists, and power and riches of nations now passed athay: with low much deeper feeling of admiration must we consider those grand monuments of nature whieh mark the revolutions of the Globe; contiwents brokitn into islands, one land produeed, another destroyed; the bottom of the ocean beeone a fertile soil; whole races of animals extinet, and the bones and exuvia of one class covered with the remains of another, and upon the graves of past generations-the marble or rocky tomb, as it were, of a former animated world-new generations rising, and order and harmony cstablished, and asystem of life and beauly produced ont of chaos and death; proving the infinte power, wisdom, and goodness of the Gineat Cause of all things!" 


\section{TABLE OF CONTENTS.}

IInts for Visitors to the IsLE of WigitT, p. I\%.

Description of the Plates, pp. 23_30.

Figures of Fossil Snelus from the Freshwater Tertiary Deposits of the

Isle of Wight, $P l$. I.

Fossil Shells and Teeti of Mamnalia from the same strata, $P$. II.

- from the Marine Tertiary Deposits, Pl. III.

of the Greensand Deposits, $P l$. IV.

do. do. $P l . \mathrm{V}$.

from the Wealden Deposits, Pl. VT.

Plan of the Geological Structure of the Isle of Wigit, Pl.VII. p. 94.

Alum B BY, from Ileadon Hill, Pl. VIII. p. 146.

Displaced Strata at Headox Hill, $7 l$. IX. p. 150.

Chalk Cujffs at Freshwater 'Gate, Pl. X. p. 194.

Сомpton Bax, from Afton Downs, Pl. XI. p. 2 I0.

Blackgang Chine, from the Seashore, Pl. XII. p. 234.

Vertical Cinalk and Flint Strata on Brading Down, Pl.XIII. p.25:.

Wealden Cuiffs, in Compton Bay, Pl. XIV. p. 274.

Culver Cliffs, from the Sea, Pl.XV. p. 336.

View of the Donsetsume Cosst, from Worbarrow Hill, Pl. XVI. p. 370.

Lulworti Cove, from the West, Pl. XVII. p. 376.

West Lulworti and Cove, Pl. XVIII. p. 330.

DURdeE Cove, Pl. XIX. p. 386.

Geological Mlap of the Isle of Wight, Pl.XX. p.30. This Map is inserted opposite p. 430. 
(it Alт:R I.-Introductory, 31. Geological principles, 57. Geology of the suutli-east of England, 59. Tabular arrangement of the strata, 63. Orter of superposition of the stritat, 65 . London eocene deposits, 66 . Chalk formation, 60. Wealden formation, 68. London and brighton railway section, 72. Geologrical mutations, 74 .

CHAPTER 1I. - Sonth-western railway, 77. Strata of the London basin, 78. London elay, so. Artesian wells, 81. The railway sections, 83. Southampton station, 86 . Southampton to liyde, 89 . Geological structure of the Isle of Wirht, 90. Rivers of the Isle of Wight, 95. From Cowes to liyde, $y \pi$.

Chaprem 111.-Freslawater eocene strata, 300, Binstead quarries, J02. Fussil rein-deer, 103. Eocene strata at Binstead, 105. Fossil charæ, 108. FussiJ land and river sletls, 110. Fossil turtles, 112. Fossil remains of extinet mammalia, 115.

Cuaprer IV.-From Ryde to (ulver Cliff, I21. Geology of Whitecliff Bay, 124. The strata and organic remains, 127. Sindown Bay, 132. Red Cliff, 135. Jlones of the loruanuion, $: 37$.

C'nA PTER V́-From liycle, through Newport, to Alum Bay, 139. The river Medina, 140. Newport to Calbourne and Alum Bay, 1:2. The coast from liyde to Alum bay, 115. Ileadon Hill and Alum Bay, 149. Geology of Headon Hill and Alun Bay, 153. Sequence of Geological inutations, 159. Organic remains, 160. Yarmouth aud Lymington, 162. Christchurch Bay, l64 strata of Jlordwell ('litis, 166. Hordwell fussils, 171 .

('Hapter VI.-The Chalk formation, 173. Subdisisions of the eretaceous system, 175. liange of the clalk thruugl the Isle of Wight, 176. The upper and lower chalk, 17\%. Chalk and tlint, 179. Silicilied fossils of the chalk, 1s1. Fossil animalcules, 153. The Firestone, 185. The Galt, ibs. 'The Greensand, I8\%). Summary of the Cretaceous system, 192.

CIIATER FlJ.-From Yarmonth to Fresliwater Gate, 19:. Scratchell's 13ay, 195. Vertical chalk strata, 199. Shattered flints, 202. The Chalk thown, 201. Cause of the present configuration of clialk hills, 206. From Hereshates tiate to ('ompton liay, 210. Gicological sections of the southern roast, 213. J'ebbles ancl shiugle, 216. 
Cirapter VIII.-From Compton Bay to Atherfield Point, 219. Atherfield cliffs, 221. Greensand series, 223. Neocomian, or Atherfield strata, 227. Greensand fossils, 229. The cliffs at Blackgang Chine, 233. The Undercliff, 237. Geological structure of the Undercliff, 240. Fossils of the Firestone strata, 242. Fossil fuci, 247. Southern range of Chalk Downs, 249. Coast of the Undercliff, 25I. The coast from Ventnor to Sandown Bay, 257.

CHAPTER IX.-The Wealden formation, 262. Nature of river deposits, 264. Wealden strata of the Isle of Wight, 269. Excursion to Brook Bay, 271. Cliffs from Compton Chine to Brook Point, 272. Brook Point, 27\%. Petrified trees, 279. Structure of the fossil wood, 282.

Cirapter X.-Organic remains of the Wealden, 286. Fossil vegetables, 286. Endogenites erosa, 288 Fossil cycadeous plants, 290. Clathraria Lyellii, 292. Fossil shells, 299. Sussex and Petworth marble, 299. Fossil freshwater bivalves, 302. Unio V'aldensis, 302. Fossil cyprides, 305. Fossil fishes, 307 .

Chapter XI.-Fossil bones of reptiles, 309. The Iguanodon, 312. The Hylæosaurus, 322. Megalosaurus, 323. Cetiosaurus, 324. Streptospondylus, 325. Plesiosaurus, 325. Fossil turtles, 326. Imprints on sandstone, 326. Ancient ripple-marks, 328. Summary of the Wealden formation, 331. The Country of the Iguanodon, 332. Voyage round the Isle of Wight, 335 .

C'uAPTER XII.-Voyage from Yarmouth to Swanage, 345. Swanage Bay, 348. The Purbeck strata, 353. Fossils of the Purbeck strata, 354. The Portland oolite, 359. Geographical distribution of the strata, 361 . Southern coast of Purbeck, 362. Kimmeridge coal, 367. South-west coast, 368. Worbarrow Bay, 375. Lulworth Cove, 376. Fossil trees, 383. Durdle Core, 385. Chaldon Downs, 389. Ringstead Bay, 390 Pseudo-volcano, 392. The Isle of Portland, 393. The petrified forest, 395. Organic remains, 400. Retrospect, 403. The Oolitic epoch, 404. The Wealden epoch, 405. The Cretaceous epoch, 406. The Tertiary epoch, 407. The Pre-historic epoch, 408. Corollary, 409.

List of Works relating to the "Geology of the Isle of Wight, and the Coasts of Hampshire and Dorsetshire," 415.

INDEX OF PLACES, 419.

General Index, 421.

Geological MaP of the Isle of Wight, opposite p. 430. 


\section{LIST OF IIITOGRAPIS.}

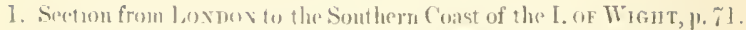

2. Lhagram of the original position of the Tlemtukr, Cunk, and IVE.Luex Forimatoxs, p. it.

3. Ideal Section from LOXDON to the Southern Coast of the IsLe or Wigit, p. 75 .

1. Fossil Skull of a RetN-perer, from Binstrad, p. $10 t$.

5. Fossil Seed-vessels of Charet, from Whitecliff Bay, p. 109.

(j. Sternal plate of a l'ossil freshwater T'uzten, from Binstead, p. 112.

7. l'ortion of the C'AR.up.Ace of a Fossil 'T'URTLe, from St. IIrlen's, p. 11 r.

s. Diagrant of the Eocene Strata in Whitecliff Bar, p. 126.

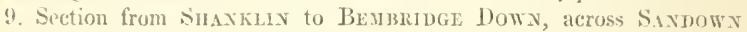
BAY, p. 13\%'

11. Section across the Valter of the Meprix, near lookley, p. Ifl.

11. Diagram of the Eorene Strata at ALuj B.IY and HEADox HiLL, p. 155.

1:. Fossil Rotalia, in llint, p. 1st.

13. Nautilus elegans, from nuar Ventnor, p. $1 * 6$.

14. Ammonites carians, from near Bonchurch, p. 1s.

15. Ammonites Ilantelli, from near Bonchurch, p. 18\%.

16. Section from Aftox Dowss to Graxge Chune, p. 215.

17. Section from Burx's Chine to St. Catinerixe's Dowv, p. 2lij.

1. Section from Brook Poixt to Sнақсомв Dowx, p. 2:20.

19. Fossil 'Teeth of a species of Hybodus, from Atlierfield, p. 8333 .

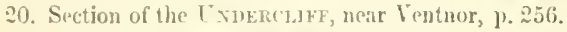

21. Leaf of Lonchopteris Hantelli, from the Cliff' near Brook, p. 257.

22. Stem of Clathraria Lyellii, from Brook Bay, p. 293.

23. Clathraria Lyellii, from Bonchureh, ], 297.

21. J'etiole of Clathraria Luyellii, p. ¿29ti.

2.5. Fussil Cyprides, from Brook Bay, 11. 307,

26. Thigh-bone of the Iguanton, from Brook Bay, p. 315.

27. A 'Tooth of the Iqumoulon, from lirook Bay, p. 317.

24. Section aeross Swaxuge Bux, p. 3tי.

29. A peolished slice of J'I Rlibeck MarkbLe, p. 353.

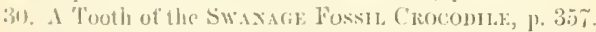

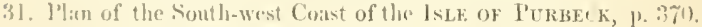

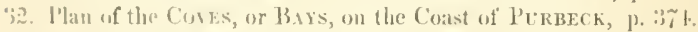

33:. Section of the West side of louswortu Corke, p. 379 .

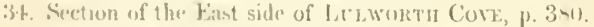

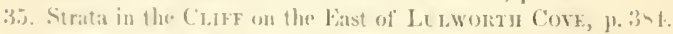

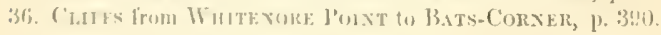




\section{HI N T F R V ISITORS}

To

\section{The Jisle of cariaght.}

As the tourists from Southampton, Gosport, Portsmouth, \&c., generally land either at Ryde or Cowes, the following Excursions are so arranged, as to afford an explanation of the geological phenomena, when proceeding from either of those towns, to the eastern, or western, extremity of the Island. But as the preliminary sketch of the Geology of the South-east of England (p. 59), conveys a general idea of the structure of the country, it is immaterial at what place the observer may commence his explorations.

"Brannon's Travelling Map of the Isle of Wight." will be found very convenient for reference; and "Barber's Picturesque Illustrations," which contains numerous excellent engravings of the most interesting scenery, will serve as a beautiful illustrative Atlas to our geological descriptions. 
Cowes. - In the vicinity of this town there are no interesting sections of the strata easily accessible to visitors, nor any locality rich in organic remains. The blocks of freshwater limestone scattered along the shore, contain the usual fossils of the tertiary thurio-marine deposits.

Ryof.* - The freshwater tertiary strata are fully displayed in the ricinity of Ryde. A delightful walk to the village of Binstead, conducts to several quarries of the limestone which is extensively used as a buikling material along the northern district of the Island. Fine specimens may here be collected of fossil freshwater shells, (see $M$. I. and II.); and these quarries are worth risiting again and again, for the chance of finding teeth or bones of mammalia, similar to those which occur at Montmartre, near Paris, and of which some relies have been discovered at Binstead, by Mr. Pratt, and Mr. Prestwich, (see P. II.). From Ryde, the Tertiary strata at Brading, Bembridge, St. Helen's, and White Cliff Bay - the Chall at Culver Cliffs - and the Wealden deposits at Sandown Bay-may be visited; and afterwards the Firestone, Galt, and

* At Ryde information may be obtained as to the best localities, and mode of visiting them, of Mr. G. Fow LSTONE, Lapidary, 4, Victoria Arcade; who has generally on sale a chrice collection of pebbles and other specimens, the genuine productions of the lsland; many of the so-called Isle of Wight pebbles, arr eithur German or Scotch agates' 
Greensand, of the Chalk formation at Shanklin, and along the Undercliff.

If the direct road from Ryde to the niestern extremity of the Island is taken, we pass by several quarries at Binstead, on the road-side; and traverse the interior of the Island, by that picturesque spot, Wooton Bridge, to Newport, and from thence to Alum Bay. Grove's hotel, on the summit of the hill, is an excellent resting-place for the visitor desirous of examining the highly interesting tertiary strata at Headon Hill, and Alum Bay. From Cowes, by Newport, the same ronte may be taken.

By the steamers we may proceed to Yarmouth,* which is the best locality for surveying the western parts of the Island. The tertiary strata at Colwell Bay, Headon Hill, and Alum Bay, are within a moderate distance; and magnificent sections of the Chalk are displayed from the Needles, along Scratchell's Bay to Freshwater Gate (see $P l$. X.). From the latter place excursions may be made either over Afton and Shalcomb Downs, (see Pl. XI. and XII.), or under the Cliff by Compton Bay, to Brook Point,

* Mr. Butler, of the Bugle Inn, Yarmouth, an intelligent pracitcal Ornithologist, will afford the stranger the requisite information as to the most interesting localities, and the best means of visiting them. He lias often accompanied me in ny geological rambles. 
where the fossil forest of the Wealden is exposed. From Brook, the Atherfield Coast-guard station may be risited, where there is a foot-track down the Clifl to the sea-shore, near the junction of the freshwater beds of the Wealden, with the marine strata of the Greensand above; a locality, which the researehes of $D$ r. Fitton have made classie ground to the geologist.

A pedestrian tour round the Island may be aceomplished in ten or twelve days, and the principal localities visited, and a good collection obtained of the organic remains peeuliar to each formation. The following notes of a trip made last summer by my young friends, the Messrs. Ciludstone, of Stockwell, may, perhaps, be useful to some of my readers.

"Monday.-By railway from London to Southampton-to Cuwes ly steaner. Examined the blocks of freshwater limestone on the sea-shore; and collected specimens of Limneus, (I'l. I. fig. 3, 4), Plenorbis ( $P$ l. I. fig. 1), and other shells. By coicls to Newport; walked to Carisbrook Castle, and after a stroll over the ruins, examined the chalk pits of Mountjoy.

I'uesday.- liode to Callourne, and visited the quarries of freshwater limestune. Walkel to Grove's hotel on the summit of the hill, over Alum Bay. In the afternoon strolled to the seashore at the foot of Ileadon Hill, and along Alum Bay; collected numerous fosil shells from the fresliwater strata at the former, and marine shells from the Lndon Clay at the latter place.

IFrinesilu! - Walked over the 1)owns to Freslwwater Gate: and from thenec hy. Ifton aud shaleomb Downs to Brook Point, 
where we examined the fossil forest of the Wealden. P'roceeded by Brixton through Atherfield to Blackgang Chine; the unfarourable state of the weather prevented our reaching $A$ therfield Point.

Thursduy.- l'roceeded along the Undereliff by St. Lawrence, Ventnor, Bonchureh, and Lueeomb Chine, to Shanklin ; stopping oceasionally to collect specimens, and enjoy the scenery. Went along the shore to Dumnose Point, and gathered uumerons fossils: among which were some leaflets of the Wcalden fern (Lonchopteris Mantelli), associated with terebratula and trigonice. Slept at Shanklin.

Friday. - Walked by the sea-side to Sandown Bay, where we colleeted many Wealden fossils; proceded to Bracing.

Saturday.-Visited the Culver Cliffs and White Cliff Bay, and obtained many fossils similar to those from the north-western part of the Island. In the evening walked to Ryde.

Nonday.-Went to the quarries at Binstead, and collected sereral good specimens of fossil freshwater shells of the same species as those at Calbourne. Left for Portsmouth; visited the Dock Yards: to London by the late train."

These young gentlemen went unattended, and without any previous knowledge of the Isle of Wight, except what they laad gathered from conversations with me, and returned home with an instructive series of the organic remains of the Island; thus affording a practical illustration of Mrs. Barbauld's admirable story of "Eyes and No Eiges." 
"To discover order and intelligence in scenes of apparent wildness amd confusion, is the pleasing task of the greological imquirer."-I) P. PAns. 


\section{DESCRIPTION OF THE PLATES.}

ORGANIC REMAINS.

Pl. I.-Fossin shells, from the freshwater Eocene strata of the Isle of Wight, at Headon Hill, Calbourne, Shalfleet, and Binstead.

Pl. II.-Fossil shells from the same deposits; and teeth of Mammalia, from the quarries at Binstead, near Ryde.

Pl. III.-Fossil shells from the marine Eocene deposits, at Alum Bay, Colwell Bay, dc.

Pl. IV.-Fossil shells from the Greensand strata of the Chalk formation. The Perna Mulleti, a very characteristic shell, is here figured.

Pl. V.-Other shells from the Greensand: the large Scaphite, which occurs in this division of the cretaceous deposits, is represented on a small scale, in Fig. 11.

Pl. VI.-A few characteristic freshwater shells from the Wealden strata.

Pl. VII.-A plan of the Geological structure of the Isle of Wight ; by Professor Jolnn Phillips. 


\section{I'l. VIII.-Alum Bar, from lieadon Hill.}

This viow is taken from the side of the hill, where the pathway from the summit of the Downs winds along the edge of the cliff, to the foot-track that conducts to the sea-shore. In this sketch, the nearly vertical Chalk strata which terminate in the isolated wedgeshaped masses, called "The Needles," are alone visible. The variegated tertiary sands and clays, that impart so remarkable an aspect to Alum Bay from the sea, form the vertical face of the cliff, on the left hand of the observer, but are not seen in this sketch. The Isle of Portland appears looming in the remote distance.

Pl. IX. - Tertiary Strata of Headon Hill, from TIIF SEA.

The face of the cliff here represented, exhibits a natural section of a series of tertiary strata, principally of freshwater origin, which have been thrown down, unconformably to the marine deposits in the adjacent cliff of Alum Bay; for while the latter are vertical, these are nearly horizontal. The foot-path runs from the Downs to the sea-shore, along the steep slope, forming the north side of the chasm that separates Headon Hill from Alum Bay; its situation is indicated by the two upper figures.

I'l. X. Chiak Cufffs, on the west of Freshwater Gate.

The face of the cliffs to the west of the landing-place at l'reshwater Gate, presents a nearly perpendicular 
section, 200 feet high, of the Upper Chalk, with numerous layers of flint, the strata being highly inclined. At the base of the projecting cliff is the entrance to a large cavern, formed by the continued action of the surge on the chalk rock.

Pl. XI.-View of the Cliffs from beyond Conpton Cimine to Brook Point, as seen from near the Base of Afton Down.

The foreground is part of the southern slope of Afton Down, and consists of the flinty chalk. The pathway winds over the brow, and leads to Compton Chine, down which a rude foot-track conducts to the beach. The strata at this point are the cretaceous ferruginous sands, which emerge from beneath the Galt on the west, and are succeeded on the east by the Wealden deposits; but the face of the cliffs along the westermmost part of Compton Bay is not seen in this sketch. The strata forming the cliffs, shown in this view, are the sands, clays, and shelly limestones of the Wealden.

The first point of land jutting into the sea, and terminating in ledges or reefs, is the western boundary of Brook Bay; at the base of the cliff is the fossil forest of the Wealden. The limits of Brook Bay are shown by the head-land beyond, which is the eastern point. The farthest land on the shore is the cliff near Blackgang Chine. Saint Catherine's Hill rises in the remote distance. 
Pl. Xll. - Blackgaxg Chixe from the sea-sllurle, LOOKING NORTII-EAST.

This view presents a fine natural section of the strata composing the Greensand group of the Chalk formation. 'The highest point in the distance is the escarpment of Saint Catherine's Hill, which is $\$ 30$ feet above the level of the sea. The upper part of the cliffs is composed of alternating strata of greenish grey sand, and sandstone; from the wearing away of the friable layers, the beds of hard grit become prominent, and appear in this view as very distinct, and nearly horizontal, bands of rock. The cliff below the thin bed of ironstone grit, from which the cascade issues, is formed of dark-coloured clay, alternating with ferruginous sand and grit. The loug-contiuned action of the water has produced a deep chasm, or chine, and the stream falls in a nearly perpendicular column from a height of serenty feet, to the base of the eliff, whence it rushes to the sea.*

\section{Pl. XIHI, - Vertical Chalk Strata on Brading DowN.}

This sketch shows the vertical position into which the originally horizontal chalk strata, have been thrown, in the central range of downs. The layers of shattered flint nodules, render the displacement of the strata ubvious to the most casual observer.

The picturesque claracter of this interesting spot is admirably shown in the views given by Sir Jlenry Englefield, and by Mr. 13arber; and also in the spirited signettes on the embellished letter-paper published by the boukne.llers in the lsiand. 
I'l. XIV.-Chiffs of Wealdin Claays in Compton hias, SEEN FROM TILE WEST.

In this view, the nearest cliffs are formed by the clays, sands, and shales of the Wealden, which constitute the cliffs and ledges, to beyond Brook Point, and almost as far as Atherfield. The inclined position of the strata is well shown in the sketch.

The horizontal layer on the top of the cliffs, is au accumulation of drifted materials, composed of gravel, clay, and loam, which in some places is from ten to twelve feet thick, and contains bog-wood, hazel-nuts, \&c. The nearest point of land is Bull-face Ledge; and that further to the east, is Brook Point, where the fossil forest forms ledges that stretch far out to sea. The extreme land is the easternmost point of Brook Bay. The view given in Plate XI. shows the continuation of the cliffs from beyond Bull-face Ledge to the western point of Brook Bay.

\section{Pl. XV.-Culver Chalk-chiffs, from thie sea.}

In this sketch, (reduced from Mr. Webster's), is shown the eastern promontory of the Isle of Wight, which is a vertical section of the chalk range, that extends from this point, in a westerly direction, right through the island to the Needles. The interrupted lines denote the layers of flint, and distinctly exhibit the highly inclined position of the strata towards the north. The dip varies from 50 to 70 degrees. The distance on the left, is Sandown Bay; on the right, are seen the eocene strata of White-cliff Bay. 
VIEWS ON THE COAST OF THE ISLE OF PURBECK :

Reduced from the beantiful lingratings by Mr. Webster, in Sir Henry Englefield's Isle of Wight.

Pl. XVI.-View of the Dorsetshine Coast, fromi Worti Barrow, LOOEING Westward.

This interesting view of the Dorsetshire coast, looking towards the west, is taken from Worth Barrow, a tumulus situated near the summit of a very high precipice of the chalk range. The bay included between the foreground and the detached rocks in the sea, is Worth Barrow Bay; the road down to which, is seen just beyond the projecting point of the chalk cliff. The rocks bounding the bay, are the Purbeck beds, corering. the Oolite. The long hill in the midlle of the view is the "Swine's back," beyond which is West lulworth Cove. The Isle of Portland appears in the distance, united to the main land by the Chesil-bank. Weymouth road is indicated by the vessels at anchor.

The deep sinuosities made in the cliffs along this coast by the inroads of the sea, are well shown in this sketch.*

Pl. XVII.-Lulmortir Cove, froy the west.

Lulworth Cove is an almost semicircular bay, formed by the action of the sea, on the vertical strata which constitute this part of the coast; and in the section thus exposed, the series of rocks, from the chalk to the oolite inclusive, may be traced. A small part of the chalk 
cliff is seen on the left of the Cove, and from that to the entrance, where the oolite appears, the intermediate strata occur. The upright rocks in the sea near the foreground, are masses of the Purbeck beds on this side of the bay, while similar blocks appear on the opposite bar. The argillaceous strata on the side of the hill are curiously contorted from lateral pressure.

\section{Pl. XVIII.-West Lulworth and Cove.}

The village of West Lulworth is situated in a deep valley, formed by an interruption of the chalk range that extends from Handfast Point, through Corfe Castle, to the coast. The Cove, which has been produced by the erosive aetion of the sea on the chalk cliffs, is about 1,300 feet in dianeter, and vessels of a hundred tons burthen, may at all times remain here in perfect security.

The hill immediately above the village, is the termination of the long ridge called the Swine's back, which is half cut into by the Cove, and presents a lofty precipitous chalk cliff. Saint Adhelm's head is in the remote distance; the nearer headland, seen above the Cove, is Gad Cliff.

\section{Pl. XIX.--Durder Cove.}

In Durdle Cove, the series of deposits from the upper flinty chalk to the Portland oolite, is exposed in a nearly semicircular bay, walled in by vertical sections of these strata. The chalk appears on the right, forming the high cliff termed Bat's Corner; and in passing from thence round the bay, the Chalk marl, Firestone, Galt, Greensand, Wealden, and Purbeck strata, may be suc- 
cessively traced to the I'ortland oolite, which terminates the point on the left of the sketch. The natural archer rock, called "Iiarn Door," at the entrance of the Cove, consists of Portland limestone.

\section{Pl. XX.-Georogical Map of the Isle of Wight.}

Each of the three Formatims, or principal groups of deposits, of which the lsle of Wight is composed, is defined by a separate colour.

The pink, denotes the tertiary Eocene strata; the shaded parts indicate the London clay, and other marine beds, in which but few, if any, freshwater fossils occur.

The blue, marks the Chalk; the chicf subdivisions of this formation, namely, the Firestone, Galt, and Greensamel, being defined by a difference in the lines of shading.

The siemma, indicates the Wealden deposits, which appear in the bays on the east, and west, of the promontory of the Under-cliff.

* * For the original sketch of the Geological Map, and for the drawings of Organic remains, I am indebted to the kindness of Professor Wooduard, of the Agricultural College, Cirencester.

The lignographs are by Mr. James Lee, of Prince's-square, Kenningtoncommon. 


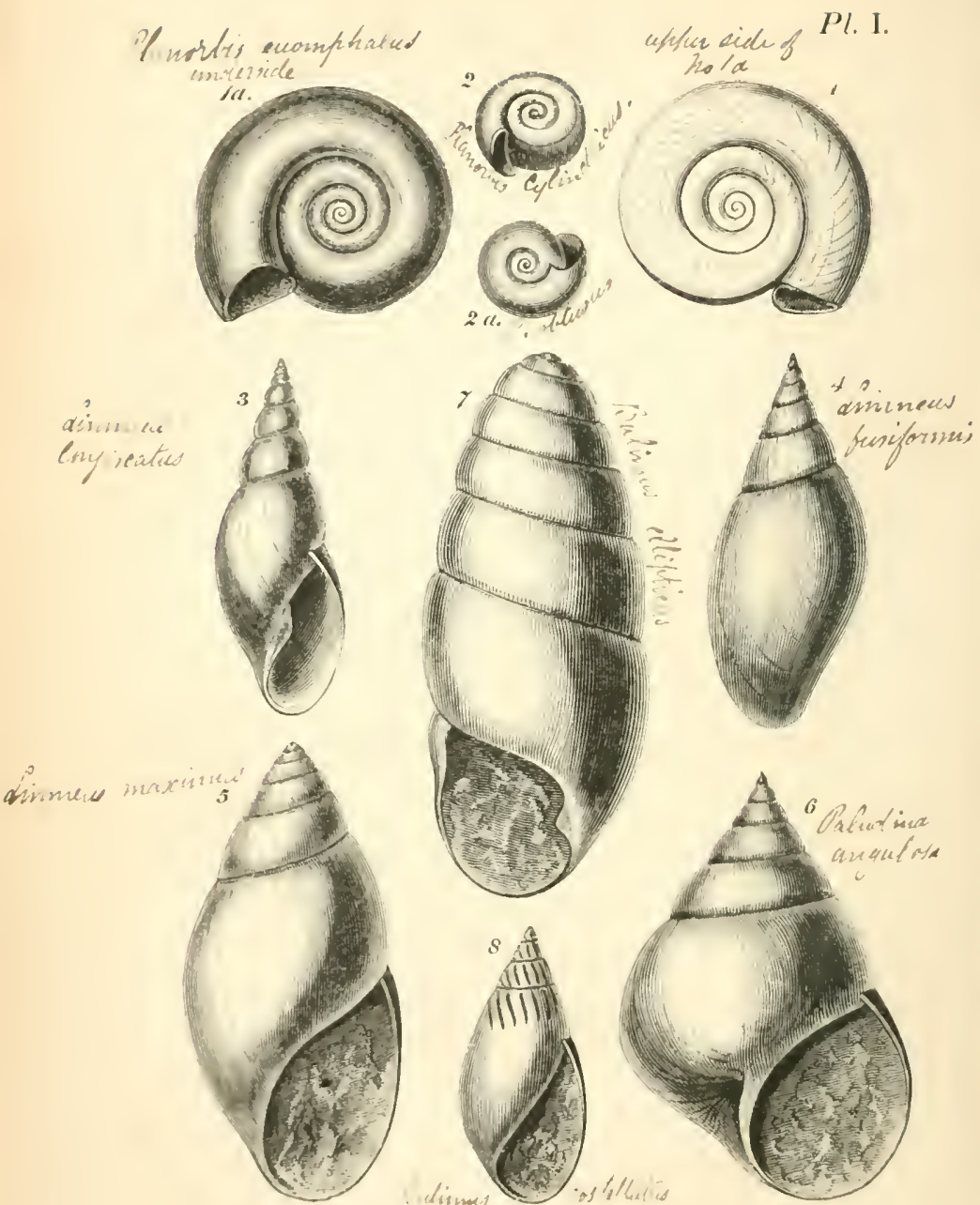

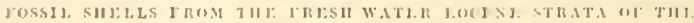




\section{DESClRPTION OF PLATE I.}

FOSNIL SIIELLS FROH THE FRESIIWITER EOCENE DEPOSITS

Fig. 1". - Planorlis enomplualus; the underside.

1.-Whe same shell on the upper side; from Calbourne.

:- Planorbis cylindricus; Calhourne.

:a.-Plunorbis obtusus; Shalfleet.

3.-Limneus longiseatus; Binsteat.

4.-Limneus fusiformis; Headon IIill.

5.-Limueus maximus; Calbounc.

6.-Paludina angulosa; Calbonrne.

7.-Bulimus cllipticus; Binstead.

8.-Bulimus costellutus; Shalfeet.

These fossil shells oecur in the limestone and marls at fleadun llill, and in the quarries at Dodspits, Shalfleet, Calbourne, and Binstead, near Ryde. The Planorbis and Limneus, are the most abundant genera; and casts of the common species may be seen in profusion in the cream-eoloured limestones nsed in the walls of cottages, Jarns, Se., in the northern parts of the Island. 



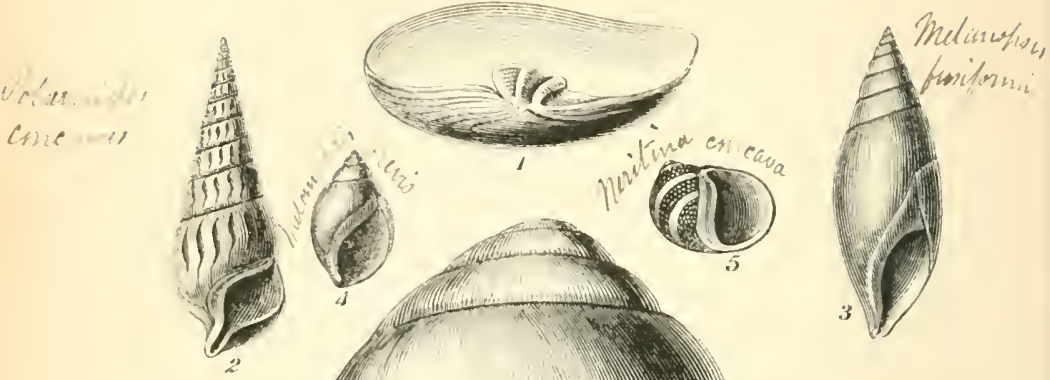

Hiulinu, win cinivita

1)tannile,
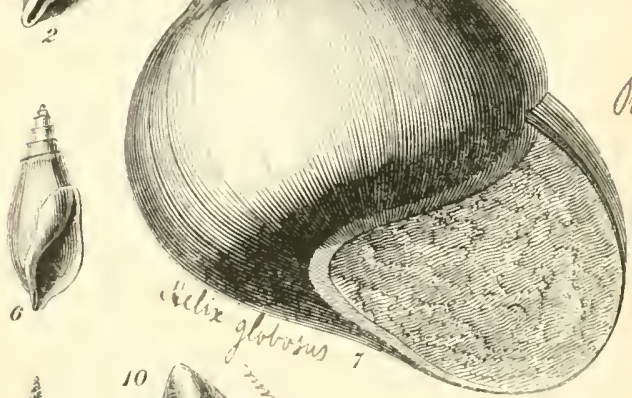
ventricentes

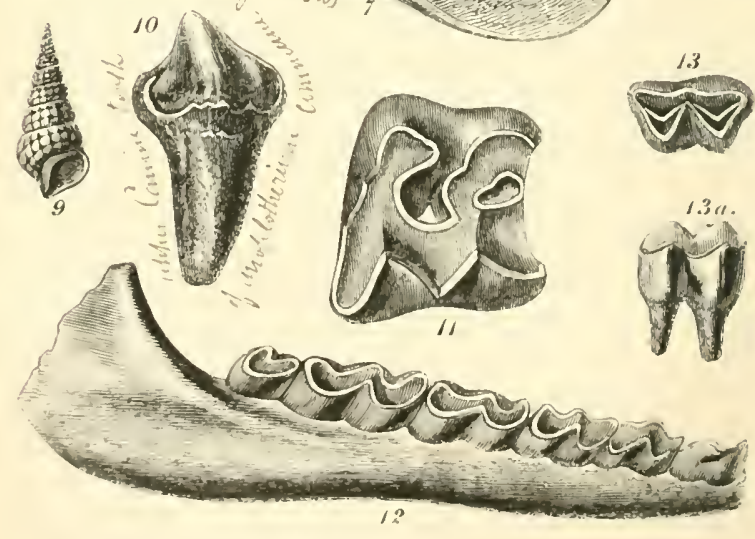

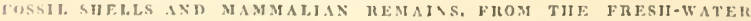
BTIATA OJ THE ISI.I OF WICIIT. 


\section{DESCRIPTIUN OF PLATE II.}

EOSAIL SHELLS AND TEETII OF MAMMALIA, FROM TIE FRESII-WATIIi LOCENE DEPOSITS.

\section{S H E L L S.}

Fig. 1._Potomomya gregaria; from ILeadon Hill.

This shell is described by Mr. Sowerly in Mineral ('oncholugy as Mya gregaria. The gentus Potomomya, (river mussels), comprises those species which inlabit rivers only, and arr not found in estnaries and brackish waters.

2.-Potumides concarus; IIeadon IIill.

3._Melanopsis fusiformis; Meadon Hill.

4... - brevis; Ileadon Ilill.

5.-Neritina concava; Colwell Bay.

6.-Melanopsis curinata; Colwell Bay.

7.-Ifelix globosus; Shalfleet.

8.--Potamides plicatus; IIeadon Hill.

9.__— rentricosus; ILeadon Lill.

\section{MAMMALIAN REMAINS.}

10.-Upper canine tooth of Anoplotherim commune; from Seafield near Ryde.

11.-The grinding surface of an upper molar, of Puleotherinm medium; from Binstead.

12.-One side of the lower jaw of Palcothcrimm minus, with five teeth ; from Seafield.*

$13^{a},-1$ tooth of Dichobune cervinum, from Binstead.

13.-The grinding surface of fig. $13^{2}$.

With the exception of the gigantic suail-shell, fig. 7 , the fossil shells here delineated are abundant at Headon IIill, and in the clays and marls at Colwell Bay. The Mammalian remains are of exeessive rarity, and have hitherto only been found in the quarries near Ryde, and at Iteadon IIill.

- See British Fossil Mammals, p. 32.. 



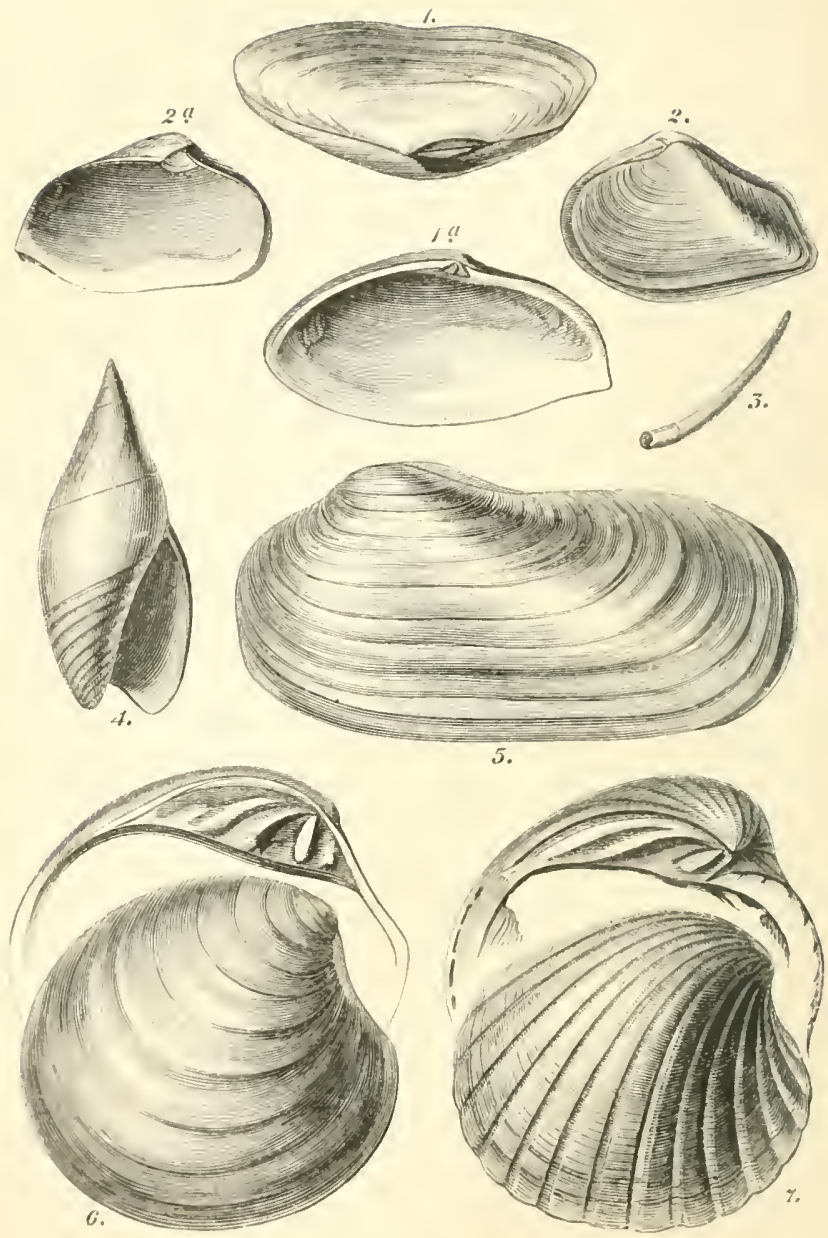

FuSSTL SHELLS TROS THI MARIXE EOCENE STRATA OF TIIE ISLE GI WICIIT. 


\section{DESCRIPTION OF PLATE III.}

FOSSIL SHELIS FROM TIE MARINE EOCLNE DEPOSITS.

Fig. 1.-Psammolia solida, the valves united; from Headon Hill.

$1^{a}$.- The inner aspect of one of the shells of the same.

2.-Corbula cuspidata, the united valses; White Cliff Bay.

$2^{a}$ - - The inner aspect of one of the shells of the same species.

3.-Ditrupa pluna; Alum Bay.

This pteropodous mollusk is abundant in the sandstone rock, that overlies the mottled elays which intervene between the Chalk and the npper Eocene deposits.

4.-Ancillaria subulate; Alum Bay.

5.-Panopera intermedia; Alum Bay.

6. - Cytherea incrassata; Colwell Bay.

7.-Carditu planicosta, half the natural size; Alum Bay.

These shells are abundant in most of the localities of the marine tertiary clays, both in the Island and on the opposite coast of Hampshire and Sussex. The l'anopea intermedia, (fig. 5), is a well-known shell in the Bognor Roeks; and the Cardita planicosta, (fig. 7), oceurs in profusion in the clay at Bracklesham Bay in Sussex. The Cytherea incrassata, (fig. 6), is found in a sandy clay at Colwell Bay, almost as perfect aud fresh as if recently left by the sea. 


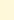




\section{Pl. IV.}
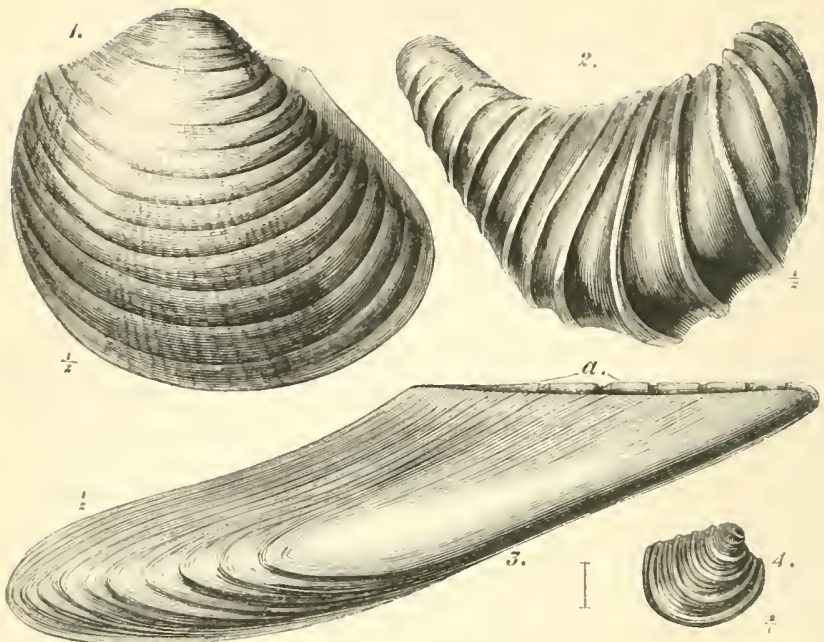

a.

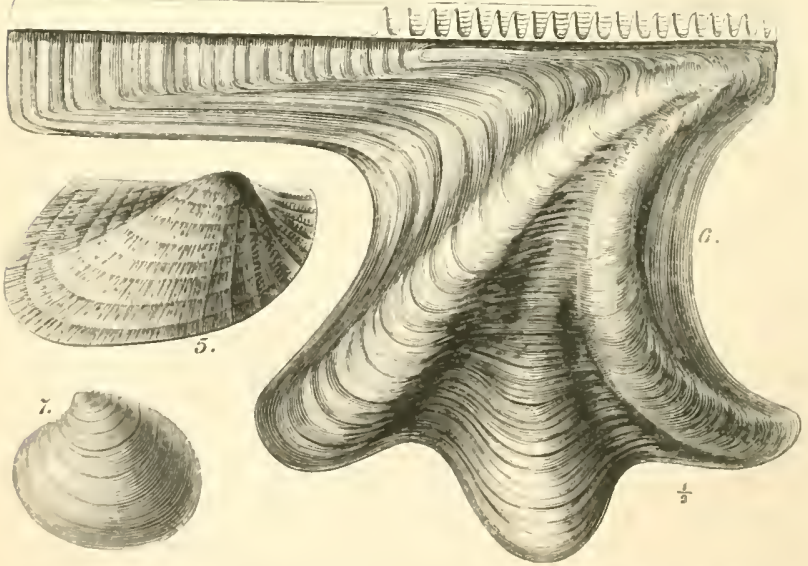

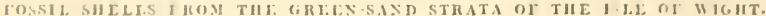




\section{DESCRIPTION OF PIATE IV.}

FONSIL SIIELLS FRON THE LOWER GREEN-SAND DEPOSITS,

Fig. 1._Corbis corrugata, from the saud-rock, Athertleld: the figmre is one-half the size in linear dimensions of the original.

D.-Trigonia candate; from the sand-rock, Atherfield.

3._Gervillin anceps; from the Cracker Rocks, Atherfield. a, denotes the markings of the linge, which are seen in consequence of the valves being slightly displaced. It is represented half the sizc linear, of the original. These shells are often much larger, and more elongated than in the figure.

t.- Tenus strituto-costata; a small shell, common in the Cracker Rocks at Atherfield; the figure is twice the size of the original in linear dimensions.

5.-Area Raulini; from the sand-rock, Atherfield.

6.-Perina Wulleti; from the lower beds of sand in junetion with the Wealden; Sandown Bay. The figure is but half the size of the original. $a$, the structure of the linge; by comparing this figure with $a$, figure 3 , the difference of the hinge in the genera Perna and Gerritlia will be recognised. This large and remarkable shell is highly characteristic of the lower beds of the Greensand.

7.- Tenus parta; from Shanklin Cliff. 

Pl. V.
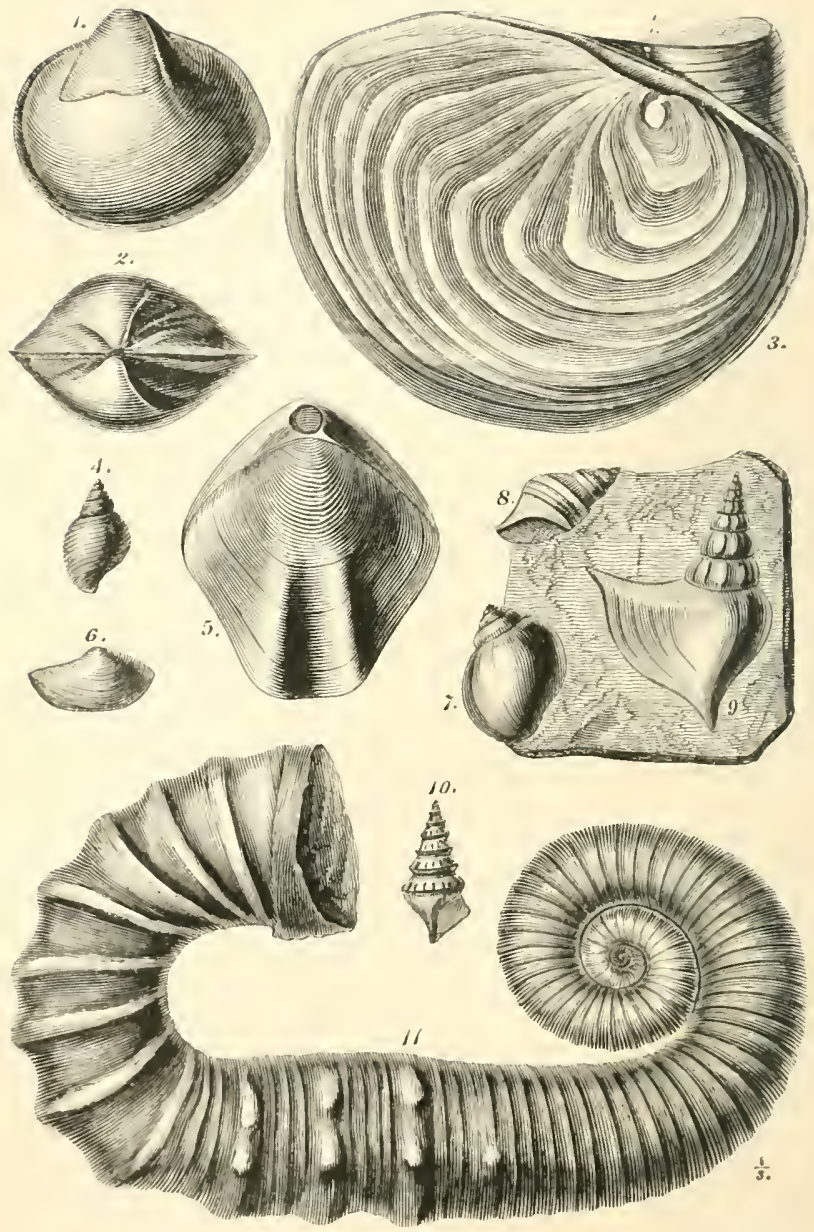

POSSIL SILLLLS VROM THE GRLEN-SAND STRATA OF THE ISLE OF WIGHT. 


\section{DESCRIPTION OF PLATE $Y$.}

FOSSIL SIIELLS FROM TIIE LOWER GREEN-SAND DEPOSITA.

Fig. 1.-Thetis minor; from the ferruginous sand-rock at the base of Slianklin Cliff.

2-Another view of the same, to show the beaks and linge-line.

3.-Gryphea sinuata; represented one-fourth the natural size; it is often found much larger. From the Green-sand at Slianklin, Ventnor, Sandown, \&e.

4.-Tomatella albensis; from the Cracker Rocks, Atherfield.

5.-Terebratula sella; an abundant shell in the sand at Atherfield.

6.-Nucula scapha; from the sand-rock, Atherfield.

The thrce following shells are imbedded in a fragment of the Crackers' Rock, from Athorfield.

7.-Natica rotundata.

8._Pterocera retusa.

9.-Rostellaria Robinaldina.

10.-Cerithium turriculatum; from $\Lambda$ therfield.

11.-Scaphites gigas; from Atherfield. The figure is but one-third the size, linear, of the original.

This fossil is often found two feet in length, associated with Ammonites equally gigantic. 



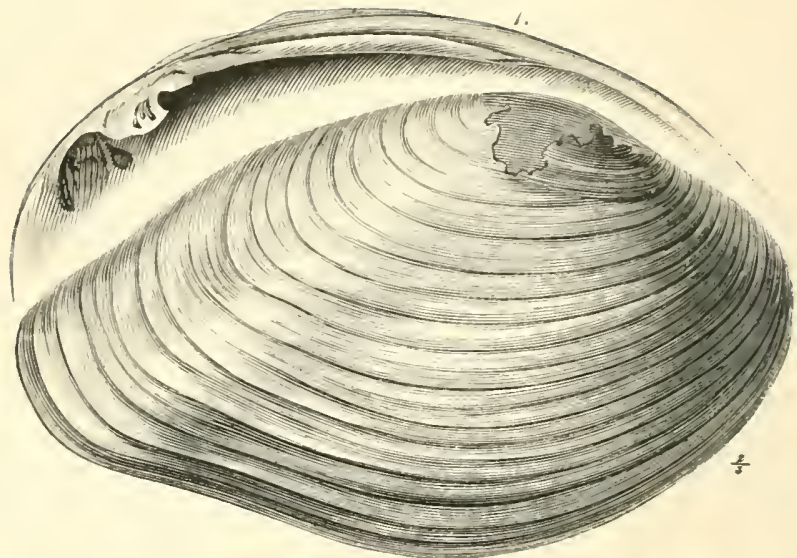

2.

3.
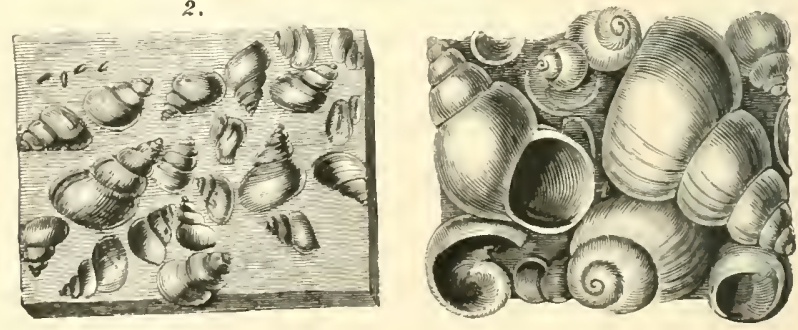

4.
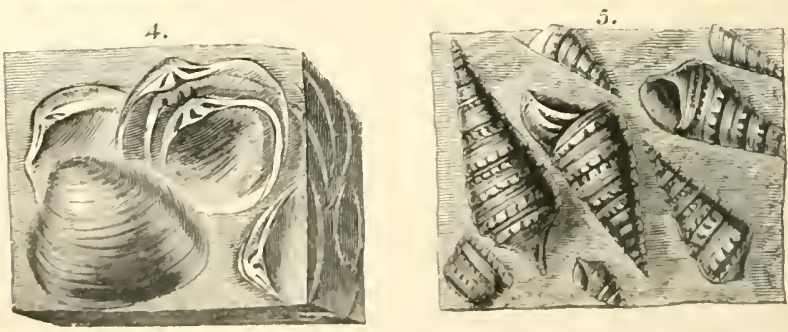

FOSSIL SILLLS PROM THE WEALDEX STRATA OF THE ISLE OF WIGIT. 


\section{DESCRIPTION OF PLATE VI.}

FOSSIL SHELLS FRONI TIE WEALDEN DEPOSITS.

Fig. 1.-Unio Taldensis; from the fossil forest at the base of the cliff at Brook-point. A young shell; the figure is two-thirds the natural size in linear dimensions. The uppernost figure gives the inner vicw of the same shell, to show the hinge and muscular imprints.

2.-Paludina elongata, in lard clay, from near Brook-point; large slabs of laminated clay covered with this species, associated with myriads of Cyprides, are continually laid bare by the inroads of the sea.

3.-Paludina fluviorum; a portion of a weathered slab of limestone, from Compton Bay.

4.-Cyrena media; in a piece of bluish-grey limestone, composed of thin bivalves; from Compton Bay.

5.-Potamides carbonarius; a slab of limestone formed of this species of fresh-water shell; from Compton Bay.

I have found the Unio Taldensis only in the cliffs, along Brook Bay; the other fresh-water shells are equally abundant in Sandown Bay. The shelly limestones of the Wealden are often used for paving, in the towns and villages of the Island. 



\title{
GEOLOGICAL EXCURSIONS
}

\author{
Rovin \\ The T) Jle of rexíabt.
}

CHAP'TER I.

INTRONECTORY-GEOLOGICAL PRIXCIPLES-GEOLOGS OF THE SOUTHEAST OF EXGLAND-TABULAR ARRAXGEMENT OF THE STRATALONDOY EOCENE DEPOSITS-CIIAL FORMATION-WEALDEX FORMATION-LOSDON AND BRIGHTON RAILWAY SECTION-GEOLOGICAL MCTATIONS.

InTroductors.-Although this work is intended to serve as a guide for the tourist unacquainted with geology, the general diffusion of the elements of the science, which has, of late years, been effected by our pexiodical literature, renders it umnecessary to enter at large upon the principles of this department of natural knowledge. Happily, the time has arrived, when the grand truths relating to the physical history of the globe, lave, like those of Astronomy, passed into acknowledged axioms ; to remind the well-informed reader that the ancient sea and river-beds which 
constitute the dry land of the British Isles have not been produced by the effects of a general deluge, would therefore be as derogatory to his understanding, as to explain that the apparent revolution of the sun round our planet is an optical illusion, occasioned by the rotation of the carth on its axis.

We may, therefore, assume, that every intelligent person is aware that the rocks and stones, and solid mineral masses, composing the dry land, have originally been in a softened or fluid state, either from the effects of water, or from exposure to a high temperature-that the strata are accumulations of consolidated mud, sand, and other detritus, the sedimentary deposits of rivers and seas, combined with the durable remains of animals and plants, which lived either on the land, or in the water-that chalk is an aggregation of shells, corals, and amorphous particles of carbonate of lime, so minute as to be undistinguishable by the naked cye, yet casily recognisable under the microscope-that the layers and nodules of flint have originated from solutions of siliceous earth in heated vapour, or water, that were periodically erupted into the cretaceous ocean - that the fossils so abundant in the chalk, are the relics of animals and plants that lived and died in that ancient scil, 
associated with the remains of a few terrestrial species-that these accumulations of organic and inorganic materials, have gradually consolidated, and subsequently been elevated from the depths of the ocean, by those subterranean forces that are every where in action, and of which the earthquake and the volcano are paroxysmal effects-and that such transmutations of the sea and the land have been, and are, constantly taking place.

Geological principles. - From the first moment that dry land appeared on the earth's surface, whatever may have been the materials of which it was composed, the disintegrating effects of atmospheric agents, and of water in motion, must have commenced. The detritus thus produced, transported to the tranquil depths of the ocean, would there subside in successive layers, and a series of sedimentary strata be gradually formed; and after the creation of living things, the durable remains of animals and vegetables must have become intermingled with the detritus of the land, and imbedded in the deposits then in progress. If the land were sterile, destitute of vegetation, and untenanted by any species of animals, the relics of the inhabitants of the sea would alone be imbedded; on the contrary, if the sediments were 
produced by the action of streams and rivers flowing through a comntry covered with forests, and swarming with animal life, the strata accumulated in lakes and inland bays would teem with the remains of terrestrial and fluviatile animals and plants.

The evidence which fossil remains afford of the changes that have taken place in the organic and inorganic kingdoms of nature, in periods antecedent to all human history and tradition, is, therefore, of the most positive and unequivocal charaeter. If, for example, a series of strata contains exclusively relics of marine fishes, shells, corals, \&c., it is obvious that it must have been formed in the sea; the state of the organic remains, and the nature of the species-whether littoral, i.e. inhabitants of shallow waters; or pelurici, i.e. species which lived in the depths of the ocean-affording indications as to the circumstances under which the formation of the strata took place. If an intermixture of land and fresh-water with marine species oceurs, it is evident that rivers and their tributaries brought into the sea the spoils of the land, and the relies of its inhabitants. On the other hand, if an extensive tract is composed of laminated elays, sands, and marls, teeming with terrestrial and fluviatile shells, and containing 
waterworn bones of land-animals, and branches, leaves, and fruits of trees and shrubs, without any intermixture of marine exuvis, we have unquestionable evidence that these strata are either the consolidated deltas of rivers, or the sediments of lakes of an extensive continent, which was clothed with vegetation, and tenanted by terrestrial quadrupeds. As the principles involved in these deductions afford an easy interpretation of the geological phenomena of the Isle of Wight, I would fain hope that the subject may be rendered intelligible to the general reader, who now, for the first time, enters upon an investigation of the pluysical structure of this interesting district.

Geology of the soutii-east of England.Before we proceed on our excursions, it is, however, necessary to take a comprehensive view of the Geology of the South-east of England; for as the "'beautiful Island," is but a detached mass of strata, severed at some remote period from the main land, a general idea of the nature of the formations of which this part of Great Britain is composed, will materially facilitate our comprehension of many local appearances, which, occurring as isolated phenomena, would otherwise be difficult of explanation, if not altogether unintelligible.

'The numerous strata, or' accumulations of sedic 2 
mentary detritus, composing the south-eastern portion of England, are separable into four wellmarked natural groups or formations.

I. 'The drift, or Allurium and Diluxium.These are the uppermost or superficial deposits, and consist of irregular layers of waterworn and drifted materials, containing the skeletons of extinct species of colossal herbivora-as the mastodon, mammoth, rhinoceros, hippopotamus, elk, deer, \&c., and in certain localities of the remains of Carnirora, Rodents, \&c., some of extinct, and others of species still existing in these islands. These beds, which rarely exhibit indications of tranquil deposition, are heterogeneous layers of debris, which have either been transported by the sea, or by river currents, or by floating ice, or driven by waves of translation occasioned by elevations of the bed of the ocean, into estuaries, bays, and ereeks.

I1. Tertiaky eocene* formation of the London BASIN.-This series is chiefly composed of layers of stiff, dark bluish-grey clay, abounding in marine shells, and having strata of sand aud gravel in the upper part, and sand, gravel, and mottled clays in the lower part, with freshwater

* Eocenr, a term applied by Mr. Lyell to the earliest tertiary formations. See " Medals of creation," vol. $\mathrm{i}$. 
shells and plants in some localities; the total thickness amounts to several hundred feet. The fossils are almost entirely of extinet species.

III. The cualk formation.--The white calcareous rock called chalk is well known; but in the nomenclature of Geology, the term Chalk formation comprises not only the limestone that extends over so large an area in the south-east of England, but also numerous beds of sand, sandstone, clay, and limestone, that are very dissimilar in their appearance and chemical characters, yet so far correspond in the nature of their organic remains, as to show that the entire group was formed during the same geological epoch. In other words, that the sea and land, and their inhabitants, mnderwent no essential change during the period in which the entire series was deposited: it therefore constitutes, in geological language, but one formation.

The organic remains of the Chalk are essentially marine; but in some localities drifted wood and plants, waterworn bones and teeth of terrestrial reptiles, and other spoils of the land, are found associated with the shells, corals, and fishes of the cretaceous ocean; and these have evidently been transported by rivers and streams into the bed of the sea. The fossils are, with but very few excep- 
tions, of extinct species and genera, and dissimilar to those of the tertiary strata.

IV. 'The wealden rormation.-This is an extensive series of clays, sands, sandstones, and shelly limestones, upwards of 1,000 feet in thickness, characterised by the entire alssence of marine fossils, and the abundarce of river and lacustrine fishes, crustaceans, and shells, intermingled with bones of enornous land-reptiles, and terrestrial plants and trees; the whole group having evidently been a rast delta.

The essential characters, of these formations, and of the subdivisions into which they are separated, are concisely expressed in the annexed table. 


\section{OF ENGLAND,}

Distribution in the 1sle of Wight.

s) Fissures in the tertiary and cre-

;- taceous strata; the subsoil in

some localities.

;

a The northern parts of the Island. The freshwater beds prevail along the northern shore, from

vs Headon Hill to White-cliff

ff Bay; the marine from Alum

3, Bay, along the northern flanks

s. of the chalk hills, to White-

it cliff Bay.

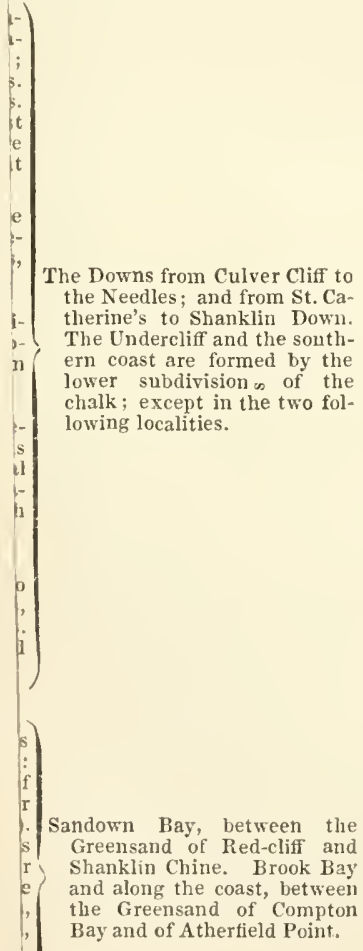


TABULAR ARRANOEHENT GF THE STRATA OF THB SOUTH-EAST OF ENOLAND.

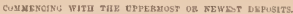

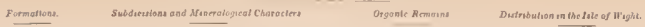

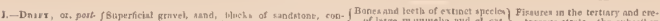

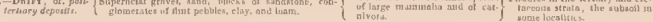

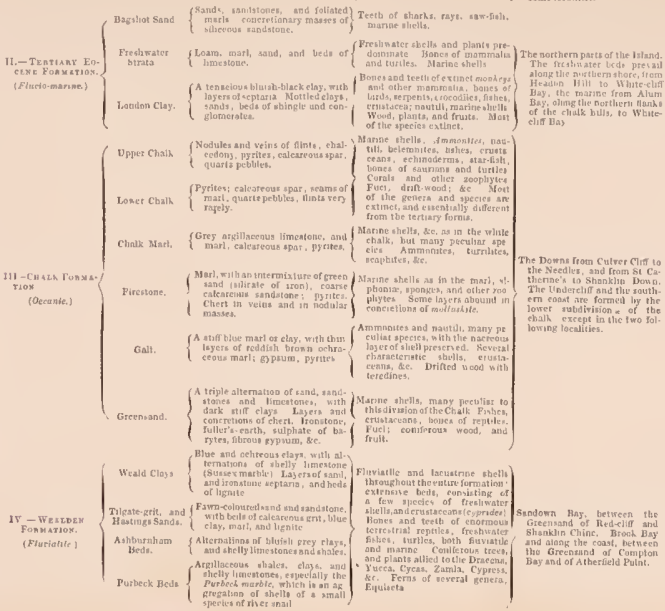


Order of superposition.-Such is the chronological sequence of the formations of the southeast of England; in other words, these several groups of marine and freshwater sediments, have been deposited in the following order:-

1st. The Wealden: the delta of a river, composed of the spoils of a vast continent, of which no other vestiges remain. These strata rest upon a marine formation called the Oolite, but which does not come within the scope of our present obserrations.

2 dly. The Chalk: the bed of an ocean of great extent, deposited upon the Wealden.

3dly. The Tertiary Eocene Formation: accumulated in depressions or basins on the surface of the Chalk.*

Now, as each of these formations is many hundred feet in thickness, it follows that the inferior strata would for ever have been concealed from observation, had the original order of superposition remained undisturbed. But not only portions of each of the upper series appear on the surface, but even the lowermost deposits form an extensive tract of country which is diversified by hills and valleys, and constitutes one of the richest agricultural provinces of the British Isles. This distribution of the strata has originated from the displacements occasioned by those disturbing forces which elevated above the waters the ancient ocean

* With the view of simplifying the subject, the Drift, or superficialalluvial deposits, will not be especially alluded to in these excursions. 
and river beds, and converted them into dry land. The nature of those changes we now proeed to consider.

London EOCENE Formation. - The London Tertiary or Eocene deposits form the area on which the metropolis is situated, as well as the surrounding country to a distance varying from ten to twenty or thirty miles. Around these strata the Chalk presents a distinet boundary of hills on the south, west, and north; but on the east the range is broken, and through this chasm the Thames winds its way to the sea.

From this geological character of the metropolitan district it results, that all the lines of railwiy that proceed from London, traverse for the first ten or twenty miles beds of elay, loam, and loosely aggregated sand and gravel; hence the numerous slips that lave taken place in the embankments at New Cross, IVandsworth, Hanwell, \&c.; and in all these lines it is obrious from the nature of the soil and the steepness of the cuttings, that similar subsidences will again occur.

Chalk formation. - The next geological feature observable along the London railways, is the Chalk, which is invariably traversed by steep cuttings and tumnels; as for example in the Southcastern linc, from Croydon to Merstham; and in 
the Great Western, from Maidenhead to beyond Wallingford. After passing, through the Chalk, the lower subdivisions of the Cretaceous formation, viz. the Marl, Firestone, Galt, and Greensand, suceessively appear; and these are followed by the Oolite on the Great Western and Birningham lines, and by the Wealden on the South-eastern; but on the South-western, by which we shall travel to Southampton, the Chalk and the Tertiary strata only are exposed.

The Chalk, as is well known, constitutes the prevalent geological feature of this part of England. The upper or white chalk rises into chains of hills, called downs, which are remarkable for their smooth and undulated outline, and form a well defined geographical boundary. The southern range extends from Hampshire, through Sussex to the sea-coast, terminating in the bold promontory of Beachy Hearl the northern passes from Hampshire through Surrey and Kent to the British Channel, and ends in the line of cliffs near Dover.

The lower cretaceous strata compose ranges of hills less uniform in elevation and extent, which skirt the inner margin and esearpments of the Downs, and in some parts of Surrey and Westem Sussex attain an altitude equal to that of any portion of the North or South Downs. 
Leith Hill, in Surrey, is nearly 1,000 feet above the level of the sea.*

WeAldex ForMation.-The Wealden deposits fill up the whole of the area between the North and South Downs, and are bounded on the west by the cretaceous strata of Hampshire, and on the cast by the British Channel; they form the seacoast from Perensey in Sussex to Hythe in Kent.

Looking down upon the Wealden, from any of the heights that command a view across the district, and of the distant boundary of chalk downs-as for example from Leith Hill, or from the summit of the escarpment of the North Downs, near Reigate + the observer might suppose that these freshwater sediments occupy a depression or basin on the surface of the chalk, and that the strata of the North and South Downs extend under the whole of the deposits in the intervening area, as in the following diagram :-

South Downs.

North

Wealds of Kent and Sussex.

Douns.

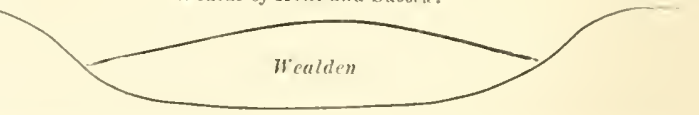

Chalk.

* For details, vide a "Memoir on the Geological Structure of the Country seen from Leitl Hill," in the County IIistory of Surrey, published by Mr. Ede of Dorking.

t See "Wonders of Geologry," vol. i. p. 342. 
Several writers on geology have fallen into this error, and indulged in the most absurd speculations accordingly. A slight examination of the relative position of the respective strata where in contact, is, however, sufficient to show the incorrectness of this hypothesis, and to prove that the Wealden extends under the Chalk, both on the north and south, as shown in the subjoined plan, and in lignographs 2,3 . It is therefore certain that the cretaceous formation was deposited upon the Wealden; and it is equally clear, that it originally extended, not only orer the entire district between the North and South Downs, and was comnected on the west with that of Hampshire and Wiltshire, but also that it filled up the space now occupied by the British Chamnel, and was united with the chalk of the Isle of Wight and of the Continent.

\begin{tabular}{|c|c|c|}
\hline $\begin{array}{l}\text { South } \\
\text { Downs. }\end{array}$ & Chalk Formation. & $\begin{array}{l}\text { North } \\
\text { Downs. }\end{array}$ \\
\hline \multicolumn{3}{|c|}{ Wealden Formation. } \\
\hline
\end{tabular}

If we assume the original position of these ancient fluviatile and marine formations to have been as represented in the above diagram, and suppose that the middle portion of the chalk, $a, a$, were 
removed, so as to expose the underlying Wealden, we should lave chalk downs on the south and north, with an intervening area of the inferior beds denuded or laid bare by the removal of the superincumbent strata. Such, in fact, would have been the actual state of the South-east of England, if the changes here contemplated had been produced by the wearing away of the chalk from the malerlying fluviatile sediments, and the horizontality of the strata had been maintained. But a careful examination of the plienomena under review, shows that the removal of the chalk was not effected by simple denudation, but by a force acting from beneath, which elevated the entire series of tertiary, cretaceous, and wealden formations in a line bearing a general direction from east to west; by which movement an anticlinal* position las been given to the strata on each side the axis of greatest elevation. 'This axis is denoted in the physical geography of the district by the chain of hills called the Forest-range, that extends from the sea-coast at Hastings through the interior of the country by Crowborough, the highest elevation, to Loxwood, west of Horsham, where the Wealden disappears beneath the overlying green-

* Anlirlinal-inelined towards each other, like the ridge-tiles of the roof of a house. 
SECTION FROM LONDON TO THE ISIA OF WIGHT. 71

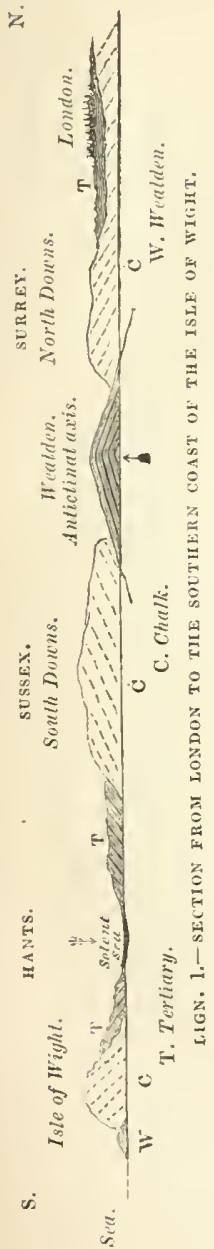

sand strata. In all transverse sections of the district, $i$. $e$. from north to south-whether on the coast, or inland-the strata on the north of the central line dip northward, or rather to the north-east, and those on the south to the south-west. There are, of course, many local variations in the inclination of the rocks, and numerous lesser anticlinal axes, or saddles, as they are provincially termed, and also longitudinal ridges and corresponding ralleys, rumning parallel with the principal line of the disturbing force.

In consequence of this displacement of the strata, a section drawn from London through the North Downs, across the Wealden district, through the South Downs, and carried on to the southern coast of the Isle of Wight, would present the arrangement shown in lign. 1.

In this lignograph are represented the tertiary of the London basin resting on the chalk; the chalk of the North Downs, dipping northwards; 
the anticlinal position of the Wealden; the chalk of the South Downs, dipping sonthwards, with tertiary strata on the southern flank: then the depression which forms the chanmel of the Solent sea; the tertiary strata extending over the northern portion of the Isle of Wight; the chalk downs of the island, dipping northward; and, lastly, a small portion of Wealden, emerging from beneath the chalk, on the south coast, at Brook and Sandown bays.

LONDON AND BRIGIITON RAILWAY SECTION.A portion of this section is well displayed along the line of railway from London to Brighton. Leaving the station at London-bridge, the tertiary clays with their characteristie fossils, are seen from beyond Deptford, by New Cross, Sydenham, \&c.; and approaching Croydon, beds of gravel appear, with interspersions of olive-green sand. 'The valley beyond Croydon, along the side of which the railway proceeds, is a thick bed of gravel resting on the chalk. Beyond the station called Stoats'nest, is a fine section of the chalk with flint, and the North Downs are traversed by a long tumnel carried through the solid chalk, and emerging near Merstham, where the firestone and marl rise to the surface. The sands and clays of the chalk are passed at the Red-hill, and Godstone stations, and the Wealden elays appear, and at 
Horley are succeeded by shales, limestones, sands, and sandstones, to the Crawley station. Passing through a long tumnel in the Wealden, we arrive at Balcombe, where laminated sandstone and shale are seen on each side the cutting. The general dip of the strata hitherto passed is to the northeast; but after crossing the deep wealden valley beyond Balcombe, over a magnificent viaduct, the line runs along alternating layers of sands and clays, which dip to the south-uest; we have therefore arrived on the southern side of the grand anticlinal axis of the Forest ridge. The Wealden strata continue with the same general inclination by Hayward's Heath, which is traversed by a tumnel, to beyond St. John's Common, where they disappear beneath the lowermost greensand beds of the chalk formation. The galt, firestone, and marl succeed, and, lastly, the white chalk of the South Downs, at Clayton Hill; through the base of which a long tumnel is carried, and emerges on the Downs on the south. The remaincler of the line to the Brighton station, runs over, or through, hills and valleys, of the white chalk. 'Thus this railway passes through two ranges of chalk hills, viz. the North and South Downs, by tunnels; two of greensand, viz. near Red Hill in Surrey, and Hurstperpoint in Sussex; and two principal ridges 


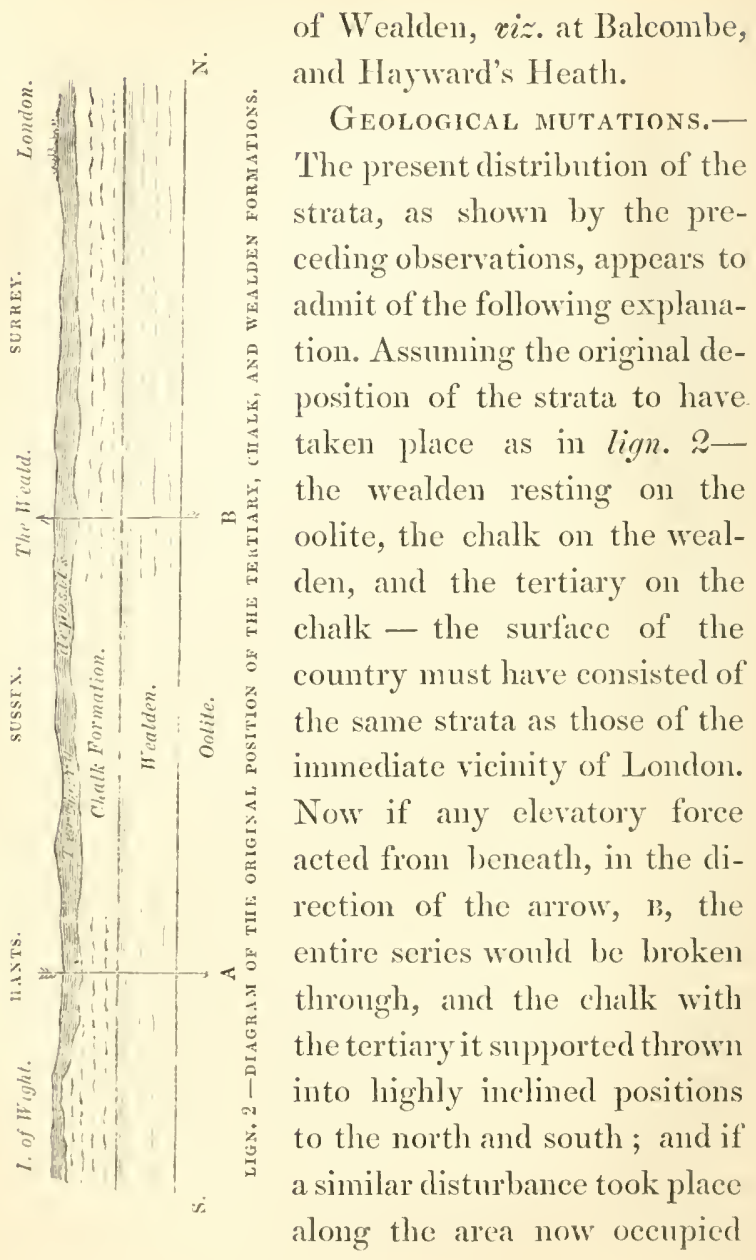




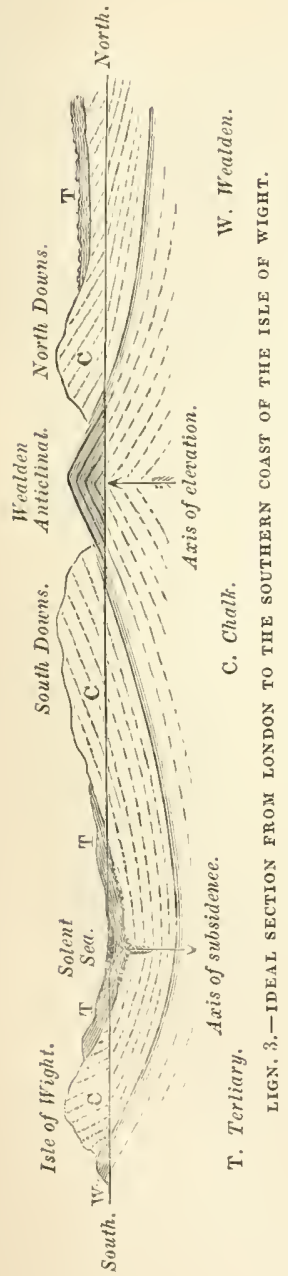

by the British Chamel, England would be separated from the continent, and the small portion, now the Isle of Wight, forced into its present position, by a subsidence taking place in the direction of the arrow, $A$, along the present bed of the Solent Sea. The actual position of the strata, could our observations extend to a sufficient depth, would probably present the section sketched in lign. 3; which is in accordance with the local phenomena that will come under review in our geological excursions round the Isle of Wight. It is obvious that if the Forest range of the county of Sussex were swept away by the encroachments of the sea, and the area it occupied buried beneath the waves, the North Downs would present a strict analogy in geological structure to the Isle of Wight; for a 
portion of the Wealden would appear on the south shore at the base of the chalk escarpment, and be succeeded on the north by the greensand, galt, firestone, marl, and white chalk; and the latter would be corered by tertiary eocene deposits."

* For detailed information on the geology of the South-east of England, and of the subjects embraced in this concise sketch, sce "Elements of Geology," hy Mr. Jyell, and the "Geology of the South-east of England," and the "Wonders of Geology," by the Author. On the elevation of the Wealden and the consequent changes in the relative level of the sea and land, the masterly paper of Mr. Hopkins, "On the Geological Structure of the Wealden District and of the Bas Boulonnais," (Geol. Trans. vol, vii.), slionld be consulted. 


\section{CHAP'TER II.}

SOUTH-WESTERN RAILWAY-STRATA OF THE LONDON BASIN-ARTESIAN WELLS-RAILWAY SECTIONS-SOUTHAMPTON STATION-FROM SOUTHAMPTON TO TIE ISLE OF WIGHT-GEOLOGICAL STRUCTURE OF THE ISLANJ-RIVERS AND STREAMS-FROM COWES TO RYDE.

Soutil-western $R_{\text {allway. - The railway from }}$ London to Sonthampton and Gosport lies so far to the west of the Wealden denuclation of the south-east of England, which is traversed by the Brighton line (see p. 7\%), that all the deposits below the Upper-chalk are concealed from view, and inconsiderable cuttings through tertiary strata, and chalk, are alone exposed.

The metropolitan station at Vauxhall, on the southern bank of the Thames, is situated on the alluvial silt and loam, which are spread over areas formerly covered by the waters of the river, and now constitute the subsoil of the meadows and lowlands that skirt its banks; these beds contain shells of recent species of fluviatile mollusca. On penetrating the soil, gravel, loam, and sand are met with, in which are found bones and teeth of several kinds of large mammalia belonging to 
extinct species of clephant, rhinoceros, horse, buffalo, elk, deer, \&c.; an assemblage of organic remains common in similar deposits in other parts of England and on the Continent.*

In the county of Surrey the subsoil of the district traversed by this milway in many parts consists of thick beds of gravel, in which fossil bones and teeth of elephants, horse, and deer, liave been discovered; but remains of this kind are more abmudamt in the loam and clay. The gravel is almost entirely formed of broken chalk-flints, worn by the action of water into boulders, pelsbles, and sand. It abounds in siliceous fossils of the chalk, and an interesting series of the sponges, zoophytes, and echini of that formation may be collected from the pits around the metropolis. $f$

STRATA OF THE IONDON BASIN.-The tertiary or eocene strata of the London basin which lie beneath the acemmulations of drifted materials above described, and fill up a depression of the chalk (sec licm. 1, p. I I), are divided into three gromps; viz. 1, Bagshot sauds ; 2, Lomdon clay; 3, Plastic clay. 'The uppermost+ consists of beds

- Sec Wonders of (ieology, tifth colition, vol. i. p. 145.

t 'The llints of the gravel often enclose beautiful examples of the microstopic fossils which abound in many of the siliceous nodules of the chalk: some of the most interesting specinens of fossil animalcules in my calsinct were olteained from the gravel on Clapham and Wandsworth commons.

f laghshot sands; so called from the district over which they are most widety expanded. 
of sand and sandstone, with intercalations of marl and clay. These strata cover the Jondon clay from near Finchley on the north to Hampsteadheath, and form part of the eminence on which Highgate is situated. The Bagshot sands appear at Egham, and extend, with some interuptions, to near Guildford; and from the vicinity of Kingston to seven miles west of Bagshot, spreading orer part of Windsor forest. Several eminences in Surrey are capped by this sand; at Tucksburyhill, north of Farnham, it occurs at an elevation of 500 fect.* From the siliceous nature of the soil formed by these deposits, the districts in which they occur are exceedingly sterile, supporting only a covering of heath and furze; hence the mumerous uncultivated wastes within a short distance of London. But where the clays rise to the surface, verdant spots appear in the midst of these desolate tracts. The situation of these argillaceous beds is inclicated by the oozing of water, and the growth of rushes in the bottoms of the shallow valleys that traverse the sandy plains, and which are often covered with peat. Some of the Bagshot sandstone is remarkable for its structure, which partakes more of the character of a peculiar crystallization than of a mere aggregation

* Brayley's History of the County of Surrey, vol. i. p.131. 
of siliccous particles; a mass of the white variety recently broken strikingly resembles the surfice of lump sugar. Erratic blocks of this sandstone are common on the chalk downs of Wilts, Sussex, Kent, \&c., and are provincially called the Grey IVethers; they occur also in the superficial drift and gravel.

LONDON CLAY.-This deposit in the neighbourhood of the metropolis forms a dark-blue stiff soil, and has occasional intermixtures of green and ferruginous sands and variegated clays. It abounds in spheroidal nockules of indurated argillaceous limestone termed septaria, which are internally traversed by veins of spar disposed in a radiated manner from the centre towards the circumference, and often contain shells and other organic remains. $\nmid \quad$ The septaria are generally distributed in horizontal layers, and lie at unequal distances from each other. Brilliant pyrites and crystals of sulphate of lime abound in the clay.

Plastic clay.-Beneath the extensive and thick deposits of London clay, and interposed between them and the chalk, there occur in some localities strata of sand of various colours, alternating with layers of bluish plastic clay; and there is very

* The septaria, when caleined and ground, constitute the composition called firman cement.

+ Medals ol Creation, p. 373. 
constantly in the lower part of the series a bed of green sand, which abounds in oyster shells, and pebbles, and in some localities (as near Bromley) passes into a hard rock or shelly conglomerate. Lignite, leaves of land-plants, and fresliwater shells are contained in some of these layers; but in many places there are no remains of this kind found in the eocene beds immediately above the chalk; and the term plastic clay, as indicating a particular group, can only be regarded as of limited application.*

Artesian wells. - From the altemation of porous sandy strata with stiff impervious clays throughout the London basin, the district around the metropolis is favourable for obtaining water, by means of the borings, termed Artesian uells; by which perennial fountains are raised from the natural reservoir of water in the lowermost arenaceous deposits. The nature of these springs is easily explained. The beds of sand under the clay are fed by the rain that falls on the uncovered margin of the basin, and the water percolating through the porous strata, gradually

* The term plastic clay (argille plastique) was given to this lowermost division of the eocene strata in conformity with the nomenclature of the French geologists; but the beds thus named are less developed in the London than in the Paris basin, and do not with us possess distinctive characters sufficiently important to warrant their separation from the other intercalated freshwater deposits of this formation. 
accumulates till a reservoir is formed beneath the central plateau of clay. If this stratum be penetrated, the water must necessarily rise to the level of the fluid in the highest part of the subterranean lake, and may therefore flow to the surface, or even escape in jets, to a considerable height above it. Such is the phenomenon of the Artesian wells in and near London. The impermeable clay confines the water contained in the sand beneath; the engineer perforates this bed with his borer, and introduces tubes for the passage of the pure element to the surface, and the exclusion of the brackish water that may ooze from the saliferous strata above; for although the wells sunk into the London clay yield no water, the sands alternating with the argillaceous beds afford a limited quantity. The prevalence of various saline minerals, howeres, in the clay, such as the sulphates of iron, line, and magnesia, generally renders the water derived from this source unfit for domestic pumposes; and the borings are carried down to the sands of the plastic clay before a copious supply of excellent water can be obtained.* The total

- The most remarkable instance of suecess in obtaining a perennial fountain from a deep source by the process of boring described in the text, is that of Circnclle, near Paris. An Artesian well is there carried to the extraordinary depth of 1,800 feet, passing through the entire thickness of the cocene strata 
thickness of the London clay, in some situations, is estimated at nearly 1,000 feet; the wells on the Surrey side of the Thames are from 100 to 600 feet deep.

The Railway sections. - The above preliminary remarks will enable the observer to understand the nature of the strata of which transient glimpses may be obtained on each side the railway in the rapid transit from London to Southampton, on which we now proceed without further comment. Although no considerable sections of the eocene strata are traversed by this line, yet here and there the characteristic soil of the London clay may be seen in the cuttings, where the surface has not acquired a covering of turf. On Wandsworth Common the banks on each side are composed of this clay with a superficial capping of gravel and sand. When the railway was in progress numerous fossils were dug up; and even now the slips of the embankments which occasionally take place, expose specimens of nautili and other shells, petrified wood, \&c.**

of the Paris basin, and the underlying chalk, firestone, and galt, to the greensand. The water rises in a powerful column to the height of 30 feet above the highest part of Paris, and has a temperature of $91^{\circ}$ Fahrenheit; being sufficiently warm for the heating of green-houses, \&c.

* See "Geological Survey of Surrey" in Brayley's History of the County, vol. i. pl. 1,2, in which several of the fossils discovered in the clay of Wandsworth Common are figured. 
At Esher the clayey district of the Bagshot sands prevails and overlies the London elay, which in our further progress is generally concealed by the sands of this subdivision of the cocene strata. At Goldsworth-hill, four miles north of Guildford, a deep section of the Bagshot sands is exposed, consisting of greenish and yellowish sands, in which fossil teeth and other remains of several kinds of fishes (principally of the Shark family), and casts of shells, have been discovered. The most interesting fossil obtained is a large tooth of a Sau-fish, which, at that time, was the only known instance of the genus Pristis in the English strata; but subsequently, examples of the tecth have been found in the clay of Bracklesham, in Sussex. The other teeth are referable to three kinds of cartilaginons fishes, and with them were associated teeth and palatal bones of Rays, and rertebra of osseous fishes, of species common in the clay of Sheppey; also a portion of the carapace or buckler of a freshwater turtle.*

At Weybridge the banks show an example of false stratification, as it is terned, of white and fawn-colonred sands, with the usual eapping of gravel and clay. At Woking Common the Bag-

- Notice of Fossils discovered in the Bagshot Sand at Goldsworth-hill, Surrey, by the Rev. Dr. Buckland. I'roccclings of the Geologicat Sociely of London, vol, ii. p. 687. 
shot sands still prevail, their sterile surface being covered with heather and broom, except in a few places, where interspersions of clay produce verdant spots, which appear like oases in the desert. Greenish elays and marls, alternating with sand, are next seen, and extensive plains clothed with heather, and dotted with clumps of pines and firs. Between Woking and Farnborough many sections of the Bagshot sands are passed, and at the Wingfield station the country presents the same geological character. Although from the rapidity of our progress but transient glimpses can be obtained of the adjacent district, yet the character of the vegetation, and the appearance of the unenclosed tracts, destitute of all traces of habitation, save a few solitary turf cabins, convey some idea of the nature of the untractable soil produced by these siliceous deposits. Such, indeed, is the general aspect of sterility in the worst parts of the Bagshot-heaths, that when the adjacent fertile region is hidden from view, a stranger might suppose himself transported to a desolate mountain moor in the border countries.*

About three miles before we reach the station at Basingstoke, $\uparrow$ the Chalk emerges, and is seen

* Mr. Warburton on the Bagshot Sancis, Geol. Trans. vol. i. p, 49.

+ The picturesque ruins of the Chapel of the IJoly Ghost, said to have been erected temp. Edward $\mathbf{L}$., on the right of the station at Basingstoke, are 
covered with a bed of tertiary sand; and at Andorer-road station the railway cutting exposes a good section of the Upper-chalk, which now continues, in greater or less thickness, surmounted in some places by patches of tertiary clays, and in others by gravel and loam, till we approach Southampton, where it is wholly concealed by the alluvial and eocene deposits. At the Winchester station, which is on the chalk of the Hampshire downs, we have a fine view of the river valley, in which stands the venerable city of the immortal Alfred, hallowed by so many glorious associations of the olden time; and we catch a glimpse of that precious monument of antiquity, the Hospital of Saint Cross, with occasional views of the crystal streams of the river Itchin, as they pursue their tortuous course through the verdant chalk-valley to Southampton-water.

Soutuaypton station. - 'The accunulations of alluvial gravel and loam around Southampton are in many places of considerable thickness. The organic remains hitherto discovered in these beds are but few ; comprising only some detached bones, and a tooth of a mammoth, and bones of a species

worthy the notice of the traveller. An clegant hexagonal turret tower at the soutli-west, and part of the east and south walls, are visible from the rallway. 
of horse and deer; and as the tertiary strata are in a great measure obscured by the superficial deposits, there are no productive localities of fossils in the immediate vicinity of Southampton. The nature of the strata to a considerable depth, has been ascertained by the borings lately undertaken to obtain a more ample supply of water for the inhabitants, than that yielded by the numerous private wells in the town. These are sunk through the bed of gravel which overlies the London clay, to a depth of from 10 to 25 feet, this clay forming the water shed or natural tank of the surrounding district. At the railway station an Artesian well, which overflows from a depth of 220 feet at the rate of ten gallons per minute, was formed by boring till the beds of sand of the plastic clay, which lie between the London clay and the chalk, were reached; the water in this well rises, therefore, from the same geological source as the springs near London.

A few years since it was resolved to obtain a more copious and constant supply for the town, by sinking an Artesian well on the Common. The operations were commenced in 1838, and have now reached a depth of 1,260 feet, at an expense of $24,000 t$. The following is the section made by the borings :- 


\begin{tabular}{|c|c|c|}
\hline soil & & 38 feet \\
\hline Lont & & $304^{*}-$ \\
\hline stie sands and elays & & 97 \\
\hline k . . & & $\$ 21$ \\
\hline
\end{tabular}

This well yields by pumping 15,000 cubic feet of water daily, but the quantity is only one half of that required, and it will be necessary to continue the borings till the firestone is reached (probably a further depth of from 150 to 200 feet) before an adequate flow of water is likely to be obtained. $f$ The impervious blue chalk-marl or galt, which underlies the firestone, generally supports an abundant sheet of water; but whether a stream will rise to the surface is extremely uncertain, and depends on the level from which the water is derived that feeds this subterrancan reserroir, and the condition of the basin which sustains it. +

The branch of the South-western railway that extends to Gosport, cuts through a few ridges of tertiary clays, sands, and gravel, capped with drift, but these present no sections of particular in-

* Nany of the characteristic sliells of these strata were brought up by the borer.

+ See an admirable Address on this suljeet to the Nayor of Soutbampton and the Members of the Artesian Well Committee, by the Very Rev. Dr. 13uckland: July, 1845. At the late meeting of the British Association of Science at Southampton, the president, Sir Roderick M urchison, and several other eminent geologists, examined the borings, and recommended the continuance of the operations till the firestone was reached.

I In the ehalk distriets of the south-east of Sussex copious streams of the purest water rise from the junction of the grey marl with the white chalk. 
terest.* At Stubbington, between four and five miles west of Gosport, near which the line passes, many interesting fossils have been obtained from the tertiary clays and sands. $\dagger$

Southanpton to Ryde.-The steamers from Southampton to the Isle of Wight generally touch at East Cowes, and proceed to Ryde; those from Portsmouth cross Spithead to the latter town, the distance being scarcely five miles. In the former route we pass down Southampton-uater, an arm of the sea which extends ten miles inland in a northwesterly direction, and separates the eastern part of the coast of Hampshire from the New Forest on the west. The entrance of Southampton-water is guarded on the west by Calshot Castle, which was erected by Henry VIII. on the narrow slip of land that here advances some little distance from the line of coast. We now obtain a distinct view of the north side of the "beautiful Island;" and as we approach the land, two parallel chains of hills may be observed, stretching in a direction east and west through the whole extent of the landscape. The nearest range is of moderate height, and slopes towards the shore; the distant

* Portsmouth and Gosport are built on eocene strata; the wells penetrate the London clay to the depth of from 200 to 300 feet.

t Several species of shells, collected by Mr. Holloway, of Portsmouth, are figured in "Sowerly's Mineral Conchology." 
chain, which bounds the horizon on the south, rises with a bolkler sweep, and to a much greater elevation, and exhibits the smooth and rounded aspeet, and undulated outline, which are so characteristic of the momntain masses of the white chalk, as to indieate their geological character, even when seen from a considerable distance. The first line of hills consists of freshwater strata, which are superimposed on the eocene marine deposits; the distant lange is part of the ehain of chalk dowis that traverses the island throughout its entire length, forming on the cast the promontory of Culver-cliff, and on the west that of the Needles (see the map, $P l$. XX.).

Geological strecture of the Isle of Wight. -Before we land, and proceed to examine particular localities, it will be necessary to take a general view of the distribution of the three formations of which the island consists. It is shown in lign. 3, (p. 75, that the Solent and Spithead oceupy a trough or channel from two to seven miles wide, formed by the London clay and other tertiary deposits which lie upon the chalk. The wells at Southampton, Portsmouth, \&c., prove, in the absence of natural sections, that although the strata have undergone great disturbauces, the same order of superposition is maintained, as in 
the sonth-east of England; and in the southem division of the Isle of Wight, where not only the lowermost cretaceous strata, but even the wealden, rise to the surface, in consequence of the highly inclined position into which the central mass of rocks has been thrown, the natural order of the deposits is not inverted.*

The Isle of Wight is of an irregular rhomboidal form, bcing in length, from east to west, twentythree miles, and from north to south, in the widest part, thirteen miles; the circumference is between seventy and eighty miles. Its surface comprises about $\mathbf{1 0 5 , 0 0 0}$ acres, of which 75,000 acres are under tillage, 20,000 acres are pasturage, and 10,000 acres umproductive heaths and commons. The population is estimated at nearly 45,000 .

The map, $P l . \mathrm{XX}$, shows the range and extent of the respective formations which lie bencath the vegetable soil and superficial loam and gravel. 'The section in the same plate represents a vertical cut through the island, from Cowes on the north, to the sea-shore beyond St. Catherine's down on the south, and exhibits the relative position and direc-

* The Underclif presents an apparent exception, for in some instances masses of white chalk are seen covered with beds of firestnne, marl, and galt; but these are merely portions of the cliffs that have fallen down in a retroverted position from the encroachments of the sea in comparatively very modern periods. 
tion of the principal deposits; these are further exemplified by the instructive diagram, $P l$. VII, p. 94.

By a reference to the map it will be seen that the eocene strata which were deposited on the chalk when the latter was in a horizontal position (lign. 2, p. 74), form the northern division of the island; this tract of country is coloured pink.

The other portion (colomred blue) is almost entirely composed of the different members of the cretaceous system. The white-chalk forms a range of downs from the eastern to the western extremity, and is flanked on the south by the lower beds of this formation. These are succeeded by another group of chalk-hills, that expands into at broad and lofty promontory, in some parts between 800 and 900 feet high, crested by St. Catherine's, Boniface, and Shanklin downs. On the southern escarpment of this chain the inferior deposits of the eretaceous system reappear, and fallen masses of these rocks form the irregular line of terraces which constitute the Undercliff. 'The downs on the southern coast are separated from those inland by an anticlinal axis which extends through this part of the Island, and is produced by the upheaval of the firestone, galt, and greensand. This is shown by the section 
from north to south given in the map $(P l . \mathrm{XX})$, in which the different members of the chalk formation are defined by variations in the lines of shading, as explained in the index of colours.

The promontory of the Undercliff is flanked both on the east and west by extensive bays, which have been excavated in the clays and sands of the wealden and inferior cretaceous deposits, by the long continned encroachments of the sea. The wealden (coloured sienna on the map) occupies an inconsiderable extent of surface; but in Sandown bay on the east, and in Brixton, Brook, and Compton bays on the west, the cliffs, which are formed of the upper clays and sands of this formation, are exposed to unremitting destruction from the action of the waves. The sea-shore is, therefore, strewn with the detritus of these fluviatile strata, and the shingle contains innumerable water-worn fragments of the bones of reptiles, and other organic remains.

That the general reader may obtain an accurate idea of the phenomena above described, the diagram, Pl. VII, for which I am indebted to my friend Professor John Phillips, is subjoined. In this plan the geographical features of the island are intentionally exaggerated, that the most important physical characters may be clearly under- 


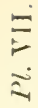

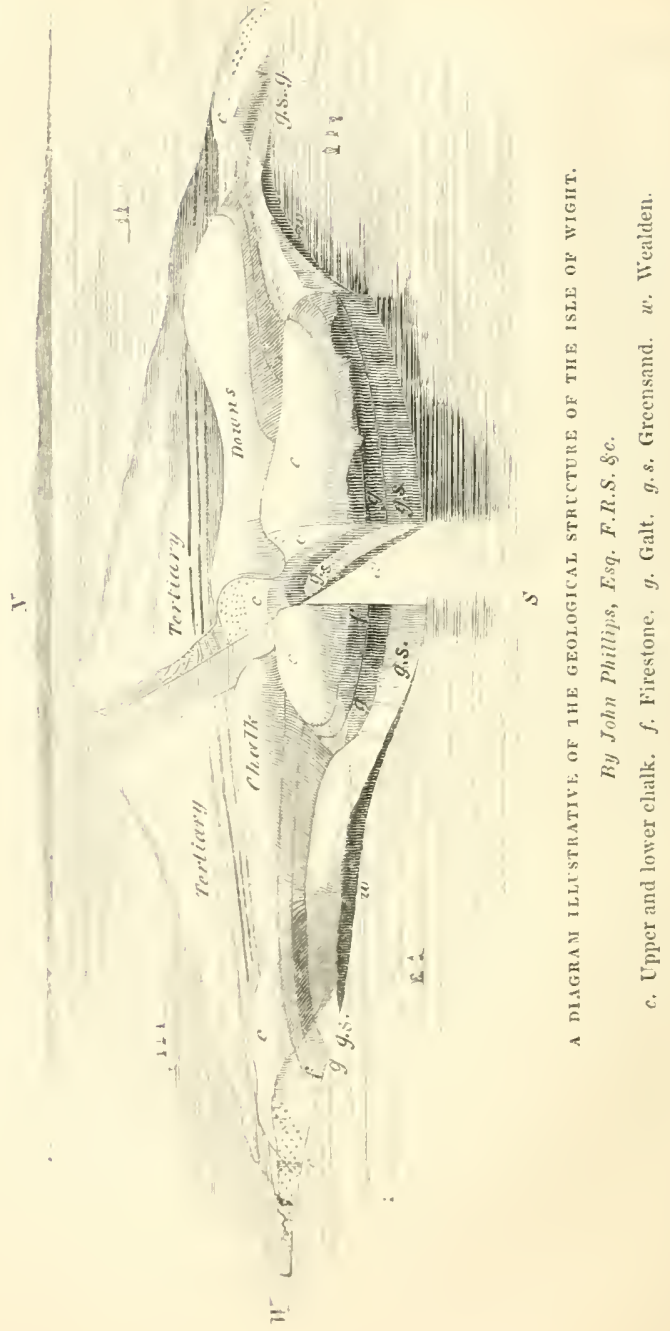


stood. The northern district, consisting of freshwater and marine eocene deposits, is marked tertiary. The chalk downs are seen in their full extent from east to west, the dotted lines denoting the inclined direction of the strata as indicated by the layers of flint nodules; and the lower members of the cretaceous system occupy the southern portion of the Island; the principal subdivisions, viz. the firestone $\left(f_{\circ}\right)$, galt $\left(g_{\circ}\right)$, and greensand (g.s.), being marked with letters of reference. The realden strata $(u$.) are shown in the bays on the east and west of the Undercliff. The vertical cut or section through the island from north to south, explains the position and flexures of the strata, which have given rise to the present geological characters of the surface of the country; the wealden constituting the foundation and central axis of the Island.

Rivers and Streaus.-There is a good supply of water, at a moderate depth, throughout the greater part of the less elevated districts; but the rivers and streams are neither numerous nor considerable. The drainage of the country is chiefly effected by four or five rivers that flow from the northern flanks of the chalk downs. Of these, the principal is the Medina, which, rising at the north-eastern base of St. Catherine's-hill, meanders 
along the valley that rums to the east of Gatcombe and Mountjoy. 'The river flows on to the east of the town of Newport, and soon expands into a wide estuary, which opens into the sea on the north; the towns of East and West Cowes being situated on the banks of the embouchure of the river.

Between Ryde and Cowes there is an estuary fed by springs that issue from the northem foot of Arreton and Ashey downs, and form a considerable breadth of water at Wooton-bridge, called Wooton-river; the estuary below the bridge communicates with the sea, and is termed Fishbourne-creek.

The most considerable estuary of the Island is Brading Haren, which covers 800 acres, and at high water has the aspect of a beautiful lake; but during low water it is a muddy swamp, through which meanders an inconsiderable river, called the Eastern $Y$ ar, originating in springs that rise at the foot of the elialk range near Godshill.

Newtown Bay, between Cowes and Yarmouth, is the mouth of a small river of the same name, which is mainly fed by a copious stream that rises near Calbourne.

The Western Yar has its source from springs that burst forth from the foot of the chalk near 
Freshwater, within a short distance of the southern shore, and quickly expands into an estuary that falls into the sea at Yarmouth, the entire length of the river scarcely exceeding three miles.

Along the southern shore of the Istand there are no streams sufficiently large to deserve the name of rivers; but the clay beds that in some parts of the cliffs are covered by porous strata many yards in thickness, give rise to copious rivulets, some of which issue from a great height, and dashing from ledge to ledge, fall into the sea in cascades of considerable picturesque beauty; those of Shanklin and Blackgang Chines (Pl. XIII.) are well known examples.

From Cowes to Ryde.-From the highly cultivated state of that portion of the Island we are approaching, and the luxuriant woods and copses with which it is adorned, its geological structure is ahmost wholly concealed from view. The waterworn blocks of limestone on the sea-shore, and the layers of tertiary strata exposed in those places where recent encroachments of the sea have undermined the low cliffs which skirt the plantations along the water's edge, afford, however, indications of the nature of the deposits composing this district. As there are no localities of geological interest around Cowes that are 
aceessible to strangers, we proceed to Rycle, the quarries at Binstead in the vicinity of that tow exhibiting good scctions of the freshwater strata, which extend through the island from Headonhill on the west, to St. Helen's and Bembridge on the east. On landing at Ryde pier, if at the recession of the tide, it will be instructive to notice the appearance of the surface of the sand and silt that extend along the shore, for it is often deeply impressed with ripple-marks produced by the action of the waves; and similar appearances will be presented to our notice on the slabs of limestone, and laminated clays and shales of the wealden, and other ancient deposits.*

The sea-shore at Ryde, during the last century, has undergone a remarkable change in its greological character, which is worthy of attention. Sir Henry Englefield $\downarrow$ states that, "when Fielding, in the ycar 1753, was at Ryde, on his royage to Lisbon, the town was totally inacessible except

* On a late visit to Ryde, the wind having a lew lours previously been cxceedingly sariable, I loum the ripple-marks formed on the surface of the muddy dumes by the agitated waters of a very remarkable character, and strikingly resembling the appearanee of the limestone covered with fossil fuci, from the Alleghany Mountains; and sliortly afterwards 1 obtainet from the Wealden at Sandown-bay a slab of shelly narble, with the upper-surfice rippled in precisely a similar mamner.

\& "Descriptions of the l'ieturespue Beanties, Antiquities, and Geological Phenomena of the lole of Wight," by Sir Henry ('. Engledichl, lart. 1sl6. 1. 16. 
at or near high water, as the tide on its recession left a vast breadth of mud, which was too soft to bear the lightest weight. But this mud-bank is now almost covered by a layer of fine white sand, which has formed a surface smooth and firm enough to bear wheel-carriages, and which renders bathing at all times safe and agreeable. This bed of sand reaches to Binstead, having, during the last fifty years, corered two miles of the shore; and it is said to be still extending to the westward. To what cause this change is owing it is difficult to explain; but it is an example of an alternation of deposits from the action of the sea in circumstances apparently unchanged." 


\section{CHAPTER III.}

FRESIIWATER EOCENE STRATA OF THE ISLE OF WIGHT-QCARRIES AT BINSTEAD-FOSSIL SKUL OF A REIN-IDER-EOCENE STRATA AT BINSTEAD-FOSSIL CHARA-FOSSIL LAND AND RIVER SHELLSFOSSIL TURTLES-FOSSIL REMAINS OF EXTINCT MAMMALIA.

Freshwater eocene strata.-The most remarkable peculiarity in the eocene formation of the Isle of Wight as compared with that of London, consists in the lacustrine and fluviatile character of the upper series of deposits, which are superimposed on marine strata identical with those of the metropolis. For though in some localities clay's and sands containing marine and estuary shells, alternate with marls and limestones abounding in fluviatile species; and in others the strata are fluvio-marine, that is, contain an intermixture of marine and freshwater shells; yet throughout a considerable thickness of deposits the organic remains are entirely fluviatile and terrestrial. In this respect the tertiary system of the Island corresponds with that of the Paris basin, which is characterised by altemations of fresluwater marls, 
gypseous limestones, and siliceous millstones, with marine sands and clays. It was from the gypsum quarries of Montmartre that those relics of extinct mammalia were obtained, which the genius of the illustrious Cuvier called forth from their rocky sepulchres, and invested anew with the forms and lineaments of life.**

In the Isle of Wight the freshwater series consists of marls, limestones, and shelly concretions, with intercalations of clay, marl, and sand; the gypseous marls and limestones, and the siliceous millstones of the Paris group are altogether wanting. Nevertheless, there is evidence that the two formations were contemporaneous, for the relics of Cuvierian pachydermata have been discovered in the Binstead limestones (see $P l$. II.).

The freshwater eocene strata of the Island, which are spread over the whole of the northern part, are denoted on the map $(P l . \mathrm{XX}$.) by pink on a plain ground; the marine beds appear on the surface as a narrow band extending along the northern flank of the chalk downs, and are indicated by the same colour on a ground shaded with parallel lines. The localities which exhibit the most instructive sections of the marine and freshwater deposits in their natural order of

\footnotetext{
* Wonders of Geology, rol. i. p. 240.
} 
superposition are Ifeadon Ifill, Alum Bay, and Whitecliff Bay.

Binstead quarmes. - The limestones in the vicinity of Ryde have been quarried for many centuries; the shelly, as well as the compact varieties, having been in great demand during the middle ages for building.* Though the sections exposed in the quarries now open are inconsiderable, they will suffice to illustrate the characters of the strata and the nature of their fossils, and render the interpretation of the phenomena hereafter to be examined more easy of comprehension. I would, therefore, first conduct the reader to Binstead, which lies about a mile to the west of Ryde. There are several quarries on both sides of the turmpike road to Newport, and others in a field which lies on the left of the footpath that turns ofl from the main road just beyond a Doric lodge, and leads by copses and hedge-rows to the picturesque hamlet of Binstead, affording here and there glimpses of the most charning rural scenery. 'The quarries for the extraction of the stone vary in depth from ten to twenty feet, and

* A great part of Winchester Cathedral is built of stone from the old quarries at Binstead. Some of the walls of Lewes Priory were faced with this stone; and several ancient Sussex churehes are in part constructed of it. 'T'ie variety composed of comminuted shells, held together by a sparry caleareous cement, was extensively used; it has been frequently mistaken for (aen stone by our antiquaries. 
appear to have been opened without regard to any regular plan, wherever it was thought a layer of compact stone could be easily reached. *

Fossil rein-deer.-Upon entering a quarry at Binstead, the dislocated state of the beds of limestone immediately strikes the observer. Vertical and diagonal fissures and chasms, extending in some places to the depth of fifteen feet, are seen traversing the solid rock, and filled with the alluvial loam and clay that form the general subsoil of this district; in these deposits bones of a species of horse and ox have been discovered. On a recent visit, I obtained a considerable portion of the skull of a Rein-deer (Cervus tarandus), from clay occupying the bottom of a vertical fissure at the depth of ten feet from the surface. It consists of the posterior part of the cranium, and closely resembles a specimen found in a cavern at Berryhead, in Devonshire, and figured by Professor Owen in British Mammalia; $\dagger$ the latter is referred by that eminent palæontologist to the recent species of Rein-deer, chiefly from the proximity of the bases of the antlers to the occipital

* Quarr Abbey. - In a sequestered valley, within a short distance of Binstead, are a few mouldering walls, the only remains of the once celebrated Quarr Abbey, which are generally visited by the tourist: the beauty of the scenery will amply repay the pedestrian geologist tor the extension of his walk to this lovely spot.

† "British Fossil Mammals," p. isi, fig. 19s. 
104 GEOLOGY OF TIIE ISEF OF WIGHT.

crest. Dr. Falconer, who, with his wonted courtesy, obliged me by comparing the Isle of Wight specimen with the skulls of recent deer in the British Museum, agrees with me in the opinion that there is no appreciable diflerence between the fossil cranium and that of the Rein-deer. Lign. 4, * represents the specimen viewed from

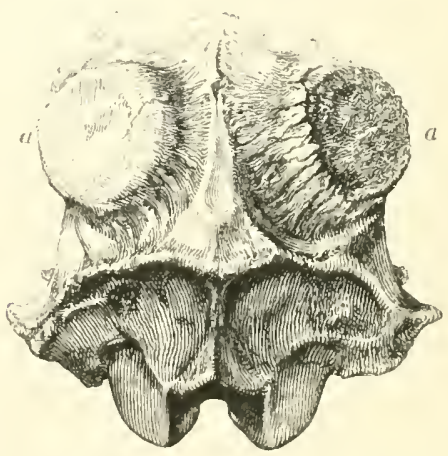

LIGS 4.-POSSIL SKULI. OF A REIS-DEER, FROM A FISSURE IN A QUARRY AT BINSTEAD

a. a. The osseous bases to which the antlers were attached.

(One-thirrt linear of the natural size.)

the occipital aspect; the figme is one-third the size of the original. The skull appears to have belonged to an adult, that had but recently shed its antlers.

- Engraved by Mr. 13agg, 63. Gower Strect. 
Eocene strata of Binstead.-'The strata in this locality are entirely of freshwater origin, containing no intermixture whatever of marine detritus. 'This is evident from the fossils, which consist of shells of the common genera of mollusca that inhabit lakes and rivers; of seed-vessels and stems of aquatic plants; bones of freshwater turtles; and teeth and bones of land mammalia. An inspection of Plates I. and II. will give an idea of the assemblage of organic remains found in this locality. The layers of stone are commonly broken and dislocated, but not far removed from their original position. On my visit last summer, the following section was exposed in the principal quarry near the road-side; it presents the usual appearance and arrangement of the upper series of freshwater strata of the Island; the beds incline slightly to the north.

1. Vegetable mould.

2. Alluvial loan and elay, in which are waterworn blocks of shelly limestone (but extending in fissures to a depth of $\mathbf{1 5}$ feet). 3 feet.

3. Sand, with a layer of shelly limestone, more or less separated into blocks which are waterworn . . . . . . . . . 2 feet.

4. Shelly limestone, in thin layers . . . . 1 foot.

5. Very tenacious loam and clay, of a dark browu colour, much resemlling in appearanee the dirt-bed of the Isle of Portland . 1 foot. 
6. Fine sand with comminuted hells . . . 6 feet.

7. Compact grey limestone; termed siliceons limestone by Mr. Webster, from its containing a large proportion of sand; but few foswils were observable . . . , 2 feet.

8. Fine sand. Water issmes from this berl, being thrown up (aceording to the quarrymen) by mderlying beds of clay.

The upper beds of limestone abound in casts and impressions of shells. No. 3, is full of hollows left by the decay of the shells, and the subsequent separation of the casts of their cavities. This bed appears to have been formed by the infiltration of calcareons matter into a layer of shells, the moulds and casts of which are now cemented together by sparry concretions. A coating of white powder on the casts is almost the only vestige of the constituent substance of the shells now observable. In this sparry limestone the minute seed-ressels of chare hereafter described, fragments of bones of turtles, and casts of planorbes (Pl. I. fig. I) and limnei (Il. I. fig. 3) are abundant.

The sand, No. 6, is intimately mingled with comminuted shells, the whole being loosely held together by an infiltration of marl; the most coherent masses readily crumble into powder between the fingers. I have not succeeded in obtaining a single shell entire; but from a micro- 
scopical examination am led to conclude that the shelly particles are the detritus of the freshwater snails (limnei, and planorbes), so abundant in the limestone; waterworn bones of turtles occur in this bed. In some of the quarries there is a layer of very hard limestene entirely composed of comminuted shells cemented together by a crystalline calcareous infiltration; it contains extremely minute waterworn fragments of turtles' bones, and, very rarely, tecth and bones of mammalia. I believe this bed to be the equivalent of No. 3, from which it cliffers simply in its consolidation, and in the absence of sand and marl. This shelly limestone is observable in the walls of the most ancient castles and religious edifices in Hampshire and Sussex.

The siliceous limestone, or rag as it is locally termed, being very compact and durable, forms an excellent building material. The upper limestones yield stone sufficiently firm for walls, \&c., and are extensively quarried in the northem district of the island. The surface of the blocks in newly erected buildings, often exposes such interesting groups of fossil shells, as to present a strong temptation to the geologist to trespass with his hammer.

I will now more particularly describe the fossils 
which occur in these strata. The shells, as we have seen, are very abnudant, but they include only a few genera and species, a cireumstance characteristic of fluviatile and lacustrine formations. With the exception of waterworn fragments of wood, the Chare are the only fossil vegetables that have come under my notice. The mammalian remains are, at present, of excessive rarity; but I doubt not diligent research would soon add to the number already known to the palæontologist.*

Fossil Cuara.-The aquatic plant termed Chara is, of course, familiar to every one, as it abounds in lakes, streams, and rivulets, throughout the kingdom. The stems are hollow, and composed of tubes filled with a fluid in which green globules circulate. 'The fruit is a minute spherical body, enclosed in a calcareous integument formed of fire spirally-twisted plates, which mite at the summit. $\nmid$ These fruits or seed-ressels when first discovered in a fossil state were supposed to be the

* I would refer the general reader, who is not conversant with the various conditions in which the remains of vegetables and animals occur in the mineral kingdom, according to the eireumstances under which they were originally imbedded, and the chemical changes they may have subsequently undergone, to my remarks "On the Nature of Fossils or Organie Remains," Clap. III. Medals of Creation, vol, i. See also "Instructions for the collecting of fossils," vol. ii. p. $8 \$ 5$.

+ Medals of Creation, vol. i. p. 188. 
shells of an unknown species of mollusk, and a genus was formed for their reception, and termed gyrogonites, or twisted stones, a name by which they are still often designated. These fossil bodies, from their extreme minuteness, are likely to elude the observation of the inexperienced collector, unless their structure and appearance are particularly noted; but a reference to the figures in lign. 5, will enable the reader easily to distinguish them, with the assistance of a pocket lens.
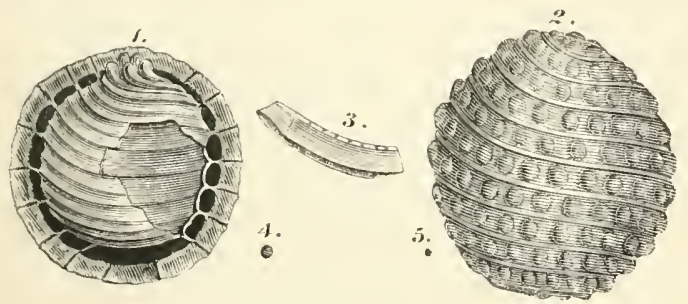

LIGN. 5. - FOSSIL SEED-VESSEIS OF CHARE.

( Mr. Lyell.)

Fig. 1.-Chara medicaginula; a section showing the nut within the pericarp.

2.-Chara tuberculata; the pericarp.

3.-Portion of a spiral valve, magnified.

4 and 5.-The natural size of figs. 1 and 2.

On breaking the compact limestone, the surface often appear's studded with small spherical cavities, and these, with a lens of molerate power, will be 
found to present the inner surface of the pericarp or shell of the Chara, the nut or kernel being absent. By a little practice, some of these fossils may be obtained with the external surface exposed, and, rarely, with the nut in the shell, as in fig. 1, which is copied from Mr. Lyell's paper in the Geolog. Trans. In the limestone at Whitecliff Bay, a species was discovered by Mr. Lyell, having the pericarp composed of nine spiral valves, covered with tubercles (fig. 2). On a recent visit to that locality, there were many blocks of limestone on the sea-shore, in which these bodies were so numerous as to constitute a large proportion of the mass, but I dirl not suceed in olstaining any specimens with the nut; the cavity of the pericar]) was generally lined with ealcareous spar. In some of the sands gyrogonites occur in abundance, and may be detected by examining with a lens a little of the earth spread out on a sheet of paper.

Fossil Sinelus.-The shells at Binstead are chicfly those of univalve gasteroporla, and belong to genera common in our rivers and lakes. The Planorbis, or discoidal river-snail, (I'l. I. figs. 1, 2,) may be distingnished by the shell being involuted or coiled up in a nearly vertieal plane; five or six species have been found. 
The Limneus, (Pl. I. figs. 3, 4, 5, ) is characterised by its elongated oval form, pointed spire, and delicate shell, with an oblique fold on the inner lip of the aperture; of this genus there are six species in the tertiary strata of the Island. The Bulimus, $\uparrow$ a genus of land smails, is comparatively rare at Binstead; but casts of the large species figured $P l$. I. fig. 7 , are occasionally met with, invested with a white friable coating of the original shell. This species is a reversed shell, that is, the aperture is to the left of the obscrver, instead of to the right, as is most common; some specimens are two inches in length. There are indications of a species of Cyclas, + a genus of freshwater bivalves, but the examples met witl are not sufficiently perfect to require particular notice. A small species of Unio§ is also sometimes found.

Specimens of the Cypris,\| a small freshwater crustacean, of which several species abound in

* Limnei and Planorbes are generally joint inhabitants of our jools and streams. They are pulmoniferous, that is, possess air-breathing organs; lence they are obliged frequently to rise to the surface of the water to respire.

+ Bulimus (properly bulinus), a genus of terrestrial pulmoniferous testaceous mollusca. These animals are herbivorous, and some of the species that inhabit warm climates are very large, their eggs heing equal in size to those of the Wren.

$\$$ Medals of Creation, p. 411.

$\S$ Unio, a genus of river mussels, of which a few fossil species have been observed in certain deposits apparently of lluviatile or lacustrine origin.

II Medals of Creation, p. 54. 
some of the eocene deposits, occur at Binstead, but I have not observed them in any considerable number.

Fossm 'Turtues.-Waterworn fragments of the bony plates of chelonian reptiles, which, from their granulated or cancellated dermal surface, appear

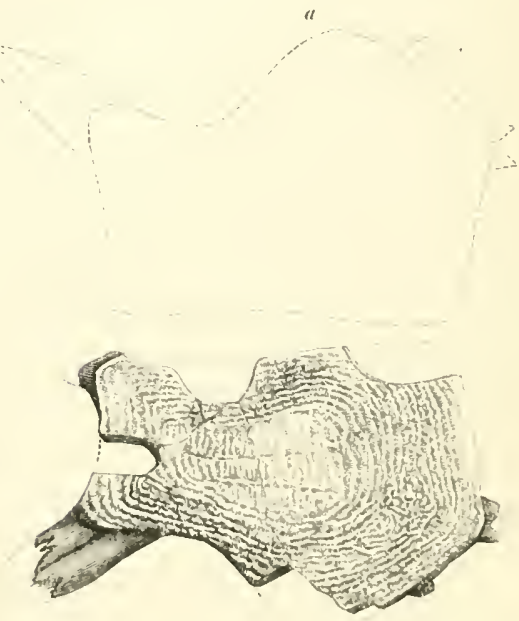

1.1(X, 6.-SILRNAL PLATE OF A FRESIIWATER TURTLE, FROM BINSTEAD.

(One-thirl linear, the natural size.)

'The outline, $a$, represents the corresponding portion of the plastron.

to have belonged to the group of soft freshwater turtles called Trionyx, are often found associated with the shells above described, in the tertiary 
limestones and sands of the Isle of Wight. It is very rarely, however, that any of the bones are sufliciently perfect to indicate the affinities of the original animal. The most instructive specimen I have obtained is the fossil represented in lign. 6 ; it is from the bed of sand marked No. 6, in the section p. 106, and when found was so thickly encrusted, that its characters were altogether concealed till the investing sand was removed.

It is one of the bones (meso-sternal) of the plastron, or sternum, of a turtle belonging to the predaceous tribe of freshwater chelonians, termed Triomyx, from having three claws. This is evident from the peculiar form of the bone, and the cancellated outer surface, which is well represented in the lignograph : an outline of the corresponding portion is added to show the position of the bone in the sternum.*

That specimens of great interest and beauty may revard more active and judicious research than has hitherto been bestowed on the palæontological treasures of the Island, is nianifest from the discovery a few years since, of one of the most remarkable fossil chelonians hitherto found in this country. It was obtained from the tertiary limestone that occurs in a low cliff near St. 
114 GEOLOGY OF THI: ISLE OF WIGITT.

Helen's, a locality we shall hereafter notice, and was sold to a dealer, who afterwards disposed of it to a casual risitor. It consists of the entire carapace or buckler of a turtle, apparently of an

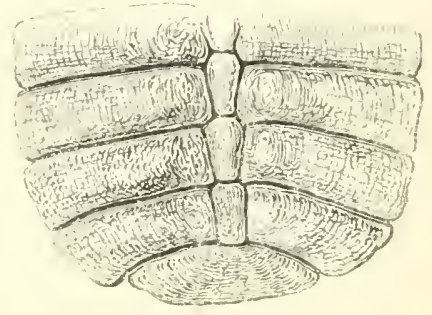

LIGN. 7.-PORTION ON THE BUCKLFR OF A FOSSIL TURTLE, FROM ST. HELEN'S.

(Size of the original carapace sixteen inches long, and nine wide.)

adult Trionyx. It is sixteen inches in length, and abont nine inches in its greatest width; and is formed of eight pairs of ribs, united by a dorsal series of eight plates. The ribs are of nearly equal breadth throughout their entire length, and have their dermal surface cancellated somewhat after the pattern of the meso-stemal plate figured in lign. 6. The buckler is as convex as in some of the land tortoises, and therefore differs greatly from the usual form of the carapace in the recent Trionyx, which is depressed, and has 
a soft flattened margin; a modification of structure enabling these animals to conceal themselves in the mud at the bottoms of rivers and lakes, and seize the molhusca which constitute their principal food.*

The only vestige of any other order of reptiles observed in these strata, is a tooth of the crocodilian type, apparently of the Alligator Hantoniensis; a fossil species described by Mr. Searles Wood, from a splendid specimen of the lower jaw and teeth, \&c., found in the freshwater beds at Hordwell Cliff, on the Hampshire coast. $\uparrow$

Fossil remains of extinct mamilia. From the general correspondence between the tertiary formations of Hampshire and Paris, it is probable that these strata were deposited contemporaneously, and under very similar conditions; their respective basins being connected with the same sea, and alike characterised by alternations of marine and fluviatile sedimentary detritus. IVhen, therefore, the attention of

* 1 very mucl regret my inability to give a correct representation of the entire carapace; but having been promised the refusal of the specimen by the dealer, I contented myself with the sketch of the part here figured; the form of the bones, and the sculpturing of the surface, are correctly shown in the lignograph.

+ Of this most interesting specimen a beautiful representation is given in the first number of the new periodical, callcd "The london Geological Journal, or Record of Discoveries in Brilish and Foreign Palaontolugy;" published by Cliurchill. 
the scientific world was directed to the fossil mammalia found in the gypseous marls of Montmartre, in consequence of the extraordinary interest with which the late Baron Cuvier invested them, British geologists were sanguine in their anticipations of discovering traces of these extinct animals in the freshwater strata of England. But not a relic of this kind was found till some years after the appearance of the "Geograph. Min. des Environs de Paris." The first evidence of the occurrence of the extinct pachyderms of Paris in the British strata was obtained by Mr. Thomas Allan, of Edinburgh, who found a lower nolar tooth of an Anoplotherium in a quarry at Binstead.* In $1830 \mathrm{Mr}$. Pratt discovered teeth and bones of Anoplotherium, Palaotherium, and Dichobune, in the same quarries; $\uparrow$ up to the present time, eight species, belonging to four genera, have been discorered in the strata near Ryde. At Headon Hill a tooth and some bones have been found by Mr. Prestwich; and from the freshwater beds at Hordwell Cliff, on the Hampshire coast, the researches of Mr. Searles Wood have recently

- This specimen was figured and described by Dr. 13uckland, in the Amnals of Philosophy, 1825.

+ "Remarks on the Existence of the Anoplotherium and Palaotherium in the Fresliwater Formation at Birstead;" by Samucl P'eace Pratl, Esq. l'.R.S. Geol. Trans, vol. iii. New Serirs. 
FOSSI, REMAINS OF EXTINCT MAMMALA , 117

brought to light several interesting additions.* The following list comprises the specimens hitherto discovered :-

A voplotilericm commune; teeth (Pl. II. fig. 10) and bones; Binstead.

secundarium ; teeth and bones; Seafield. $\dagger$

Chzropotames Cuvievi; part of the lower jaw with teeth; Seafield; by Rev. W. D. Fox.

Palazotheriom medium; teeth ( $P l$. II. fig. 11); Binstead. magnum; a tooth; Seafield; by the Rev. W.

D. Fox.

crassum; teeth; Binstead and Seafield.

minus; right ramus of the lower jaw with five molar teeth ( $P l$. II. fig. 12); portions of the skull, radius, and tibia ; Seafield, near Ryde ; by the Rev. W. D. Fox.

Dienobene cervinum; lower jaw and teeth (Pl. II. fig. 13); Binstead; by Mr. Pratt.

All the fossils in the above list are figured and described by Professor Owen in "British Fossil Mammals," + a work of the highest interest, replete with the most profound views of the correlation of animal organization, and therefore of inestimable value to the palæontologist. I have introduced figures of a few teeth in $P l$. II., that

* See London Geological Journal, No. 1, pp. 5, 6 .

† Seafield is a little hamlet to the east of Ryde, but the quarries are not accessible to strangers.

士 "A History of British Fossil Manmals and Birds. By Rirhard Owen, F.R.S. \&c." 1 vol. 8 vo, with numerous Illustrations. Published hy Van Voorst, London, 1846. 
the reader who visits the Binstead quarries may be aware of the appearance and characters of these relies; the lower jaw of the Palcotherium minus, with five molar teeth (I\%. II. fig. 1 $\mathscr{2})$, is a higlily instructive specimen.*

It is mmecessary to enter at large on the structure and habits of the pachydemata to which these remains belonged; for eren the forms of these extinct beings must be familiar to the reader, as Cuvier's restorations of several species are introduced into every popular work that treats of the ancient inhabitants of our globe. $\downarrow$ The Anoplotheria are remarkably distinguished by having feet with but two toes, as in the ruminants, and an uninterrupted dental system; the teeth being placed in a continuous series, as in man, without any interval between them. The $A$. commune was eight feet long, and of the height of a wild boar, but of a more elongated shape; it had a long and thick tail, which, it is supposed, like that of the Otter, assisted it to swim with facility; from the structure of the teeth it is inferred that it browsed on grass like the horse. 'The $A$. secun-

* The Paleotherium had seven molar teeth on each side the lower jaw ; in the specimen figured, three true molars, and two of the premolars, remain; the seventh or last molar has three erescent-shaped lobes; the otlers but two each.

1 T'he details of their anatomieal structure are given in Cuvier's "Ossemens Fossiles," "um, iii. 
darium was a smaller species. The Chroropotumus was of the hog tribe, and nearly related to the Peccari, but one-third larger. 'The Palaotherin resembled the Tapirs in the form of the head, and in having a short proboscis, but their molar teeth were more like those of the Rhinoceros; their fore-feet had but three toes, instead of four, as in the Tapirs. Upwards of eleven species, varying from the size of the Rhinoceros to that of the Hog, have been discovered in the tertiary strata of France. The P. magnum was of the size of a horse four or five feet high, with a massive head and proboscis, and short extremities. The $P$. medium was one-sixth smaller than the American Tapir, but had longer and slighter legs and feet. The P. minus was an elegant creature of the size of the Roebuck, with light and slender limbs. The Dichobune is related to the Anoplotherium, but characterised by the peculiarity of its dental system, which approaches that of the ruminants in the cusps of the molars having a tendency to form a double series of crescents. (See Pl. II. fig. 13.*).

We must here terminate our investigation of the strata exposed in the quarries near Ryde, and 
120 GEOLOGY OF THE ISLE OF WIGHT. proceed to the eastem end of the island, to examine the marine deposits that underlie the fluviatile and lacustrine strata, to which our attention has hitherto been exelusively direeted. 


\section{CHAP'TER IV.}

FROM RYDE TO CULVER CLIFF-GEOLOGY OF WHITECLIFF BAYSTRATA AND ORGANIO REMAINS - SANDOWN BAY - BONES OF COLOSSAI REPTILES.

From Ryde to Culver Cuiff. - On the north side of Culver Cliff, the eastern extremity of the chalk downs and of the island, the long-continued action of the sea on the tertiary strata has excavated an irregular bay, which is bounded by cliffs that expose a section of the entire series of marine and freshwater eocene deposits. This excavation is called Whitecliff Bay, and is about nine miles from Ryde.**

The road from Ryde passes over a country prettily diversified by gentle hills and dales; but the strata are concealed by pasturage and cultivation, and the geological character of the district can only be traced in the low borders along the sea-shore, and in the pits and quarries opened

* See the diagram, $P l$. V1I. p. 94; and the Map, $P l . \mathrm{XX}$. The reader will remember that Whitecliff and Alum Bay are natural sections of the vertical and horizontal tertiary strata that extend through the island from east to west, on the north of the chalk downs. 
for the extraction of limestone for conomical purposes. The whole of this tract consists of freshwater marls, clays, sands, and limestones, like those of Binstead. As we approach Brading the chalk downs which form the horizon rise up in bold relief, and flank the tertiary strata on the south. On the stmmit of this line of hills is the signal tower on Askey Doun, which forms a conspicuous object in the landseape.

The picturesque town of Brading, with its venerable church, stands on a low ridge of chalk; and in descending the gentle declivity beyond, the highly-inclined position of the chalk may be pereeived in the bank on the right-hand, the layers of flint being nearly vertical. As we proceed, the marl, firestone, and galt appear, and are succeeded by the ferruginous sands belonging to the lowest group of the cretaceous system, and which continue to the sea-shore at Sandown. But our route lies to the left, and we pass by euttings of chalk and marl, Brading Haven

* Brading Church. This interesting edifice is supposed to have been erected soon after the Conquest; but, inclependently of its claims as an object of antiquity, it deserves notice from laving been for many years the seene of the pastoral labours of the late Rev. Legh Riclimond. The admirers of that interesting $A$ uthor who visit the island, should procure the cheap and elegant hittle hand-book to the scenes deseribed in the "Annats of the I'nor," entitled "fhe Landsenpe Branties of the lshe "ff Wight, as described by the lute Rew. Legh Richmond ; by George Brannon." 
being spread out before us on the left, till we approach Yaverland church,* which stands on a little knoll orershadowed by ehms, near the foot of Bembridge Downs. From this spot there is a narrow road to some fields on the north of the hill, through which a path leads to the brink of the precipitous cliff that overhangs Whitecliff Bay, near the junction of the chalk and eocene strata. Here a very steep foot-track winds down the face of the cliff, which is covered with ferms and brush-wood to the sea-beach. But the main road leads to Bembridge, $\neq$ and Whitecliff is reachect by a walk of nearly two miles along the shore. After much rain, however, the bay is scarcely accessible, for mud and sand-banks

- I'averland church is supposed to have been erected in the twelfth or thirteenth century. It was in this church that LEGH RIenmond made his first attempt to preach extempore, and completely failed; though he was afterwards celebrated for the power and eloquence of his extemporaneous discourses. This interesting spot is graphically described by Mr. Richmond in "The Dairyman's Daughter." "It is pleasantly situated on a rising bank at the foot of a bold chalk hill, and being surrounded by trees, has a rural and retired appearance. Close to the churchyard stands a large and ancient mansion, which was formerly the residence of an opulent and titled family, but has long been appropriated to the use of the estate as a farm-house. Its outward aspect bears considerable remains of ancient grandeur, and gives a pleasing character to the spot of ground on which the church stands. In every direction the roads that lead to this sacred edifice possess distinct but interesting features. One of them aseends hetween several rural cottages from the sca-shore, which adjoins the lower part of the village street; another winds round the side of the adjacent hill; and a third leads to the church by a gently rising approach, between bigh banks covercd with young trees, bushes, ivy, hedge-plants, and will flowers."

+ There is a good hotel at Benibridge, and a passage ferry across the moutl of Brading llaven to St. Helen's. 
obstruct the way, and the slippery state of the grómd renders walking most wearisome.

Geology of Whitecliff Bay.-From Bembridge, the tower of an ancient church painted white, and serving as a land-mark, is seen on the opposite side, on the northern point of the haven; the pretty village of St. Helen's, embosomed in trees, stands on the brow of the neighbouring hill. A low cliff, composed of freshwater strata, may be observed near its base; and from this locality the fossil turtle, described in p. 114, was obtained. The cliffs immediately beyond Bembridge are from twenty to thirty feet high, and consist of alluvial gravel and clay, resting upon freshwater strata; the ledges and rocks on the sea-shore are denuded waterworn masses of the limestone that have fallen from the cliff. After passing the Foreland, and proceeding a few hundred yards along the shore, the tertiary calcareous deposits form the base of the cliffs, and lie in a nearly horizontal direction; but towards the northern extremity of the bay they gradually rise, and at length are bent upwards in a curved position, and rest somewhat unconformably on the almost vertical beds of clay.* 'This is the point of junction

* A beautiful sketch of this part of the cliffs is given in $P l . \mathrm{XV}$.; and of the Bay, in $1 \%$. XVII. No. 1, of Sir IIenry Englefield's "Isle of Wight." 
of the freshwater and marine series of the Isle of Wight eocene deposits. The eliff now entirely consists of the London clay beds, which are exposed wherever there is a break or slip in the turf-covered slopes. These strata become more developed towards Culver Cliff, where the lowermost tertiary, and uppermost cretaceous strata, are in juxta-position.

The magnificent ehalk cliffs of Culver ean only be seen to advantage from the sea (see $P l$. XIV.); the dip of the beds is about $70^{\circ}$ to the north, and is well defined, even from a distance, by the layers of flints. Most of these siliceous nodules, though imbedded in the chalk, and still retaining their original forms, are splintered to atoms, probably from the concussion produced by the upheaval of the strata; this phenomenon was first pointed out by Sir Henry Englefield.*

Whitecliff Bay, though destitute of those remarkable characters which have rendered Alum Bay so attractive to the tourist, is highly interesting to the instructed observer. From the period when Sir H. Englefield and Mr. Webster first directed attention to the phenomena here exhibited, this locality has been explored by many

* See Linnæan Transactions, vol. vi. p. 108; also, Fossils of the South Downs, p. 151.

$$
\text { G } 2 \text {. }
$$




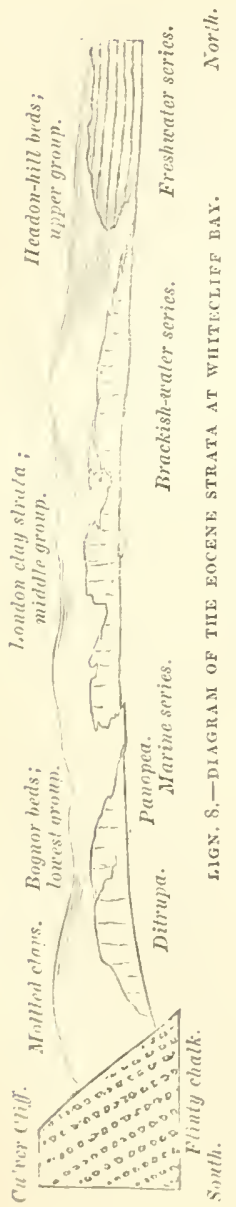

eminent geologists, ${ }^{*}$ and the mineralogical character, organic remains, and order of succession of the strata, have been aceurately detemined. $f$ But a few montlus since an elaborate and important memoir, with ample illustrations, and details, was laid before the Geological Society by Mr. Prestwich.+ In the present work a concise view of the most interesting facts is alone admissible, and which the annexed diagram (lign. 8), from a section exhibited by Mr. Prestwich, will serve to render intelligible.

The cocene strata in Whitecliff Bay appear in the same order of superposition as at Alum Bay, as we shall point out when we visit that locality; but the eliffs before us are less

* In 1822 Mr. Lyell made an accurate examination of this cliff, and faroured me with a series of specimens and a detailed section of the strata.

+ See list of publications relating to the (ieology of the lsle of Wight, in the Appendix.

‡ since published in the "Quarterly Journal of the Geological Society;" August, 1846. 
precipitous than those in the north-west of the Island, and their slopes are corered by debris, and in many places with regetation, down to the shore.

The eocene deposits of the Isle of Wight, according to the investigations of $\mathrm{Mr}$. Prestwich, may be regarded as forming three principal groups; viz. the upper freshwater series, and the marine series, which is divisible into the London clay, and the Bognor deposits (see limn. S).*

Tile strata and organic Remains.-If we retrace our steps from Culver Cliff towards the Foreland, we find that the lowermost tertiary strata, those in actual contact with the clialk, consist of mottled plastic clays, in which no vestiges of anmal remains have been observed. These are followed by a brown sandy clay, with septaria, \&c., and a series of sands, sandstones and clays, which abound in species of shells of certain genera, long known to prevail in the strata that cmerge along the western coast of Sussex, and

* The Bognor fossils were first mentioned by Mr. Webster; a more extended notice was published in my "Fossils of the South Downs," and "Geology of the South-East of Fingland." "The roeks at Bognor are evidently the ruins of a deposit once very extensive, and which, even within the memory of man, formed a line of low cliffs along the coast; at present a few groups of detached roeks, covered by the sea at high water, alone remain, and the puriod is not far distant when these will be swept away by the action of the waves. These beds are deeidedly analogous to the calcaire grossier of Paris."-Geol. S. E. of England, 1.51. 
particularly at Bognor; the rocks on the shore at that watering-place consisting of coarse sandstone full of similar fossils. The lowermost or earliest bed of this series, is a layer of brownish clay with green sand (in some parts passing into concretionary sandstone) ahmost made up of the tubular shells of one species of pteropodous mollusk, the Ditrupa plana, formerly called Dentalium planum, (Pl. III. fig. 3); the Bognor rocks are full of these shells. The clays and sands that succeed swarm with certain marine bivalves (ostrece, myce, turritelle, pectunculi), which also occur at Bognor. The Panopaca intermedia (Pl. III. fig. 5), is a very characteristic fossil.*

A considerable thickness of rariously coloured sands and clays, in which no organic remains have been found, is next in order; and then the suite of deposits of the London clay teeming with marine exuvix. Among the shells are the species figured in $P$. III. figs. 1, 2,4 , 6,7 : the Cardita planicosta (fig. 7 ), is a strong and thick bivalve that abounds in some of the argillaceous beds, and often attains a large

* The position of the strata containing the Ditrupa and the Pannpar, is slown in the diagram, lign. 8. A few weeks since, several bloeks of the greenish limestone, covered with Ditrupe, were lying on the beach near the spot indieated. 
size.* Shells of the genera Nummulites, $\uparrow$ Veuus, Ancillaria, Voluta, Cerithia, \&c., occur in inmense numbers; + and in the greyish blue clay are myriads of minute species. Teeth and bones of fishes, and of reptiles, and remains of crustaceans (crabs, lobsters, \&c.) are occasionally found. In the upper beds of the London clay lignite.(carbonized wood), and shells of certain genera which inhabit estuaries (Melanopsis, Pl. II. figs. 3, 6, ) and some freshwater species are met with, indicating that the strata were deposited in brackish water. These are the uppermost of the highly inclined marine beds at Whitecliff Bay.

* At Bracklesham Bay, on the western coast of Sussex, the clay, at low water, is in many parts literally paved with these shells, and great numbers may be collected in a very short space of time. Bracklesham is also prolific in numerous other fossils of the London clay. In 1821, I made a considerable collection of the organic remains of this part of the Sussex coast, and published a list of them in the "Fossils of the South Downs," and a more extended one in the "Geology of the South-East of England." But of late years diligent research has brought to light numerous fossils of great interest; and besides many new species of shells, vertebræ and bones of fishes, serpents, turtles, and crocodiles, have been collectcd. For an excellent notice of this locality by Mr. Bowerbank, see "Medals of Crealion," vol. ii. p. 903. $M I r$. Dixon has a splendid collection of the Bracklesham fossils, comprising several new species of Mitiobatis (eagle-ray), Aëtobatis, and other genera of the Rays. Spincs of these fishes, and of a species of Silurus, have also been discovered.

† Nummuliles, a fossil polythalamian shell, of a discoidal flattened form, resembling a coin, hence the name. See "Medals of Creation," p. 242.

$\ddagger$ A chisel as well as a hammer, and a pickaxe to breal up large masses of the stiff clay in which the shells are imbedded, will be required to extract perfect specimens. 
130 GEOLOGY OF THE ISLE OF WIGHT.

The freshwater series next appears; but in the lowermost division of this group there is an intermixture of estuary and marine shells; these deposits would, therefore, be more correctly designated furio-marine. Cálcareous marls, sandstones, and limestones, abounding in fluviatile and lacustrine shells, similar to those of Binstead, form the succeeding portion of the cliff. On a recent visit the fallen masses of rock were full of fossil seedvessels of chara (C. tuberculata, lign. 5, p. 109). Some of the upper strata are of a fluvio-marine character, and within 100 feet of the superior layer, thrice is a seam of oyster-shells in a bed of marl near the top of the cliff at Bembridge-ledge, which was pointed out by Mr. Lyell in 1894.

There are several layers of pebbles in the marine vertical strata; and in some of the calcareous sandstones of the upper series, pebbles and angular fragments of flint are imbedded, alternately with seams of freshwater shells.

The total thickness of the cocene strata at Whitecliff Bay is about 650 yards; * of which, according to the measurements of Mr. Prestwich, the mottled clays are 112 feet; the Bognor series about 300 feet; the London clay 980 feet; and

* Where the beds are vertieal, the horizontal distance of course expresses Ine thickness of the deposits. 
the fluvio-marine and freshwater group 550 feet.

The assemblage of organic remains in these deposits is regarded by Professor E. Forbes as indicating the following sequence of changes in the condition of the basin in which they were formed. "This fauna, which did not begin until after a considerable thickness of mottled clays, in which no traces of animal organization appear, had been deposited upon the chalk, commences by numerous peculiar mya-form shells, pectunculi, ostrex, and their associates, in a series of sands and clays. The earliest fossiliferous bed is a most remarkable one, consisting of a thin stratum, almost entirely composed of the shells of a pteropodous mollusk (the ditrupa plana, Pl. III. fig.3), which appears to have continued but a short specific time in life, and to have entirely disappeared. In the midst of this group, strata charged with myriads of foraminifera (nummulites), probably indicating some change in the depth of the sea, appear, and cease. The sudden conversion of the sea into a freshwater lake, denoted by a stratum of paludina clay, its return into a brackish state, and the consequent reappearance of certaiu marine animals - its reconversion into a freshwater lake thronged with myriads of fluviatile mollusca (plan- 
orbes, limnei) - and the almost momentary influx of salt water during that period, which lasted only long enough for a race of oysters to live and die away-all render the tertiary strata in this locality of high interest." *

It may assist the collector to state that the ditrupa bed is exposed in the cliff at the distance of from 45 to 50 paces from the junction of the lowermost tertiary clay with the chalk. At 150 paces further, towards Bembridge, are greenish grey sands and clays, in which the cardita planicosta (Pl. III. fig. 7), and numerous other marine shells occur; and about 200 paces onwards similar shells, with large nummulites, volutes, cerithia, \&c., are abundant in strata of the same character. $\dagger$

Sandown BAy.-To pursue the natural order of our inquiry, we should now retrace our steps to Ryde, and proceeding to the north-western extremity of the Islind, examine the corresponding phenomena in Alum Bay. But it may be more convenient to the visitor if we first conduct him to the southern side of Culver Cliff, where a natural section of the strata of the cretaceous

* Report of the fourteenth meeting of the Brit. Assoe. of Science for 1844. 'Transactions of the Sections, p. 44.

+ See an interesting paper "On the London and Plastic Clay Formations of the lsle of Wight," hy J.S. Bowerbank, Lisq. F.R.S. Geol. Trans. 
system (see table, p. 63), and of the upper Wealden deposits, constitutes the line of cliffs forming the boundary of Sandown Bay (see the Map, Pl. XX.).

But we shall restrict our remarks to a very general description of the geological structure of these cliffs, and reserve a particular account of the chalk and wealden formations till we enter upon the examination of the south-western localities of these deposits.

From Bembridge we return to the foot of the Downs by Yaverland church, , and thence through the village to the sea-shore, near the centre of Sandown Bay, the distance from Yaverland scarcely exceeding a mile. $\downarrow$ It is desirable to alight before we reach the Fort, and as near to the coast as possible, and then proceed along the strand towards the eastern end of the bay. + The annexed sketch, from the accurate sections of Dr. Fitton, will convey a general idea of the relative position of the strata.

* There is a small chalk-pit on the side of the hill worth examination, as it well displays the highly inclined position of the clialk and flint strata.

+ The stranger must not attempt to go round the headland of Culver Cliff by the strand, even at low water; Sandown Bay can only be safely reached in a boat, except by the road described in the text.

I At the village of Sandown there is an inn where refrcahment may be obtained for "man and horse." The coaeh from Ryde to Ventnor stops at the King's Head, near the sea-shore, where the geologist travelling by this conveyance should alight. 
134 GEOLOGY OF THE ISLE OF WIGHT.

ڤั)

๘ี

The distance comprised in the section is between four and five miles; Slıaklin Down forms the western, and Bembridge Down the eastern limit. $\mathrm{O}_{n}$ the eastern side of the luay the flinty chalk has a total thickness of about 900 feet; the louer chalk and chall marl, 200 feet; the firestone 100 feet; and the galt 50 frect. The greensand beds that follow, correspond with those of Atherfield cliffs, which we shall hereafter risit, and contain similar fossils; the lowermost bed aboumding in that remarkable and characteristic shell, the Perna Mulleti (Pl. IV. fig. (6). The Tiealien deposits oceupy the midalle of the bay; and on 
the west, the sands and clays, of the grcensand reappear, and form the cliffs from Sandown to Shanklin, where they are covered by the galt, firestone, chalk-marl, and flinty chalk; the latter attaining an elevation of nearly 800 feet. Sandown Bay comprises, therefore, a double series of the strata of the cretaceous system, thrown into an anticlinal position by the elevation of the realden, which constitutes the axis of this line of coast.*

Along the middle of the bay opposite the Fort the subsoil, except after very heary tides, is concealed by a thick bed of shingle.j

Red Cliff.-On proceeding eastward a low bank appears, and the coast gradually rises to the lofty hills of Red Cliff. The strata first acessible to observation are the ferruginous sands and mottled clays belonging to the wealden formation, which become more developed as we advance towards the chalk strata that terminate in the

* The anticlinal axis and order of superposition of the strata at Sandown Bay, and the correspondence of these deposits with the wealden and cretaccous systems of Sussex and Surrey, were ascertained more than twentyfour years since by Mr. Lyell, and communicated to me in a letter dated Bartley Lodge, July, 1S22, accompanied by a section from Culver Cliff to Shanklin Down, and a suite of specimens comprising examples of all the principal deposits; this collection is now in the British Museum.

+ In the section, for the sake of perspicuity, the wealden strata in the middle of the bay are represented more lofty than they actually appear; for in general the sea-beach extends over the whole surface. But after sweeping spring tides in the early months of the year, the clay and sands are exposed as here represented. 
bold promontory of Culver, which forms a striking object from this part of the bay. In the slingle may be found rolled blocks and pebbles of the wealden shelly limestones; and of jasper and quartz, with rolled silicified zoophytes that have been washed out of the chalk.

In the wealden, bones of large reptiles, and fruits of coniferous plants, have from time to time been discovered; and many colossal bones of the Iguanodon have been obtained from the shingle. Slabs of the paludina-limestone (see Pl. VI. fig. 3), commonly called Sussex marble, and of indurated shale full of freshwater bivalves ( $P l$. VI. fig. 4 ), may generally be seen protruding from the clay.* Masses of lignite that have fallen out of the cliffs are often found on the beach, and sometimes pebbles of silicified wood. A few hundred yards before we reach the chalk strata, laminated clay and shale appear in the face of the cliff, and the surfaces of most of the lamina are studded with myriads of the cases of minute freshwater crustaceans, termed cyprides (see lign. 25), belonging to two or three species which are peculiar to the wealden deposits.

\footnotetext{
* In a late visit to this spot ( $\Lambda$ ugust 1846) a layer of Sussex marble having a band of fibrous calc-spar an inch thick, above and below, was exposed in the clay near the base of the cliff.
} 
It is only after recent slips of the cliffs from the inroads of the sea, that the beds are clearly exposed, and after heavy rains, that the fossil bones are brought to view by the washing away of the clay in which they are imbedded; but at all times instructive specimens of the strata, and of the usual species of shells, may be obtained. The greensand and galt are not so prolific in fossils as in some other localities; but the marl and firestone contain many organic remains characteristic of those beds.

Bones of the Iguanodon, \&c.-The occurrence in this locality of bones of the Iguanodon and other reptiles whose remains had previously been observed only in the strata of Tilgate Forest, was first made known in 1829 by the present Dean of Westminster, Dr. Buckland. An enormous toe-bone (metatarsal), weighing six pounds, and measuring six inches in length, and sixteen inches in circumference at its largest extremity, was found in the ledges of ferruginous sand, a little to the east of Sandown Fort.* A considerable number of bones, comprising several gigantic vertebræ, portions of a femur or thighbone, fragments of ribs, \&c., were discovered near the same spot, at the foot of the low cliff that

* Geol. Trans. vol. iii. p 425. 
forms the sea boundary of Yaverland farm. 'They were observed on the shore after a week of very stormy weather, which had swept away the beach and sand to the depth of two feet, and thus laid bare the fossils, which probably had fallen from the clifls long previously, and being very heary, had sunk deep into the shingle, and lain concealed till brought to light by the denuding effects of the storm. In the adjacent cliff of grey sandstone interspersed with clay, several cones of a plant allied to the Zamia, mixed with fragments of lignite, have been discovered.*

We now retum to Ryde that we may proceed to the north-western part of the Island, and examine the eocene strata at Alum Bay and Headon Hill.

* One of these fossil fruits is figured and described in "Brifish Fossil Floru," under the name of Zumit crassa; and in "Medals of Creation,' vol. i. 1) 160. 


\section{CHAP'TER V.}

FROM RYDE TO NEWPORT-THE RIVEI MLDINA-NEWPORT TO CALBOURNE AND $\triangle L U M$ BAY - THE COAST FRUM RYDE TO ALUM BAYHEADON IILL AND ALUM BAY-GEOLOGY OF IIEADON HILL AND ALUM BAY-SEQUENCE OF GFOLOGICAL CILANGES-ORGANIC REMAINSYARMOUTH AND LYMINGTON-CHRISTCHURCH BAY - STRATA OF IIORDWELL CLIFFS-HORDWELL FOSSILS.

From Ryde, through Newpont to Alum Bay. - From Ryde, the journey to Alum bay may be performed either by land or sea. The road passes by Binstead, and through the picturesque village of Wooton-bridge, to Newport, the capital of the Island. In the rooms of the Newport Institution, there is a miscellaneous collection of organic remains; but it is much to be regretted that a complete series of specimens, illustrative of the geology of the Isle of Wight, is not to be met with in this, or any other town, in the Island.

Newport is situated on freshwater eocene strata, which are a continuation of those of Headon Hill, and lie in a nearly horizontal position; the wells in the town are sunk through these beds, to the 
depth of 200 feet. At Parkhurst barracks, a wel! was dug through 300 feet of London clay, containing a few thin seams of shells. On examining the nature of the soil in the tract between the town and the neighbonring chalk hills, the vertical marine strata are found occupying the same relative position as at Whitecliff Bay.* In a heap of clay that had recently been dug up from the bottom of a well, Mr. Webster discovered vestiges of coleopterous insects; and obtained several fossil seed-ressels of a plant related to the Meadou-rue (Thalictrum); they consisted of the pericarp, in a carbonized state, filled with clay. $\downarrow$

The quarries in the neighbouring chalk down of Mountjoy, to the southward of the town, expose some interesting sections of the highly inclined strata of chalk and flint; and the summit of the hill commands a most extensive and delightful prospect.

Rrver Medina. - The Medina river, which rises at the foot of St. Catherine's Down, and divides the Island into two nearly equal portions, called the East and West Medina, flows through

* Mr. Webster notices a clay-pit, opened for a brick manufactory, in which were clay and sand strata, in a nearly vertical position, and the upper portions contorted as if from pressure. Sir II. Englefield's "Isle of Wight," pl. xxxiv. fig. 1 .

$\uparrow$ A figure of this fruit (which has been named by M. Adolphe Brongniart, Thulictroides Websteri,) is given in the "Medals of Creation," vol. i. p. 190. 
a transverse valley of the chalk range on the south, and winding round the east end of the town, becomes navigable for vessels of considerable burthen, to its entrance into

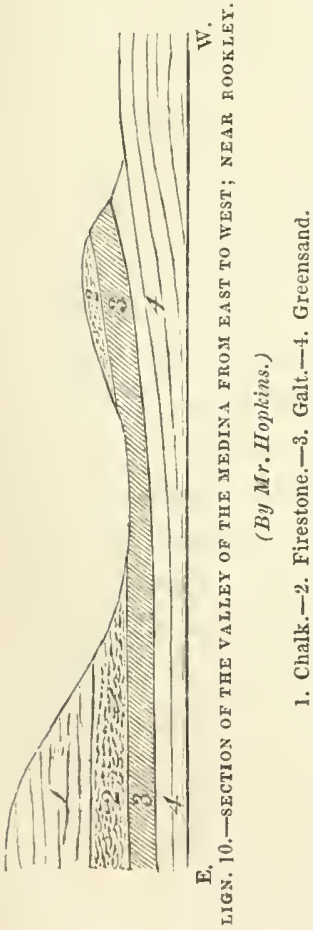
the sea at Cowes. 'The val. ley of the Medina, like the river valleys of the North and South Downs, * is a transverse dislocation, or rent, across the range of chalk hills, produced by the tension of the strata during their elevation from the horizontal to their present nearly vertical position.

The transverse course of the Medina through the midi dle of the central ridge of 娄 chalk, is noticed by Mr. - Hopkins, in his memoir "On the Geological Structure of the Wealden District, and of the Bas Boulonnais," + with the accompanying diagram, lign. 10, which represents an east and west section of the valley

* Geology of the South-Fast of England, 1. 350.

+ Gcol. Transactions, vol. vii. p. 24 . 
near Rookley, about four miles south of Newport. "It presents," observes Mr. Hopkins, " a nortlı and south line of flexure which must almost necessarily be accompanied by a corresponding north and south fracture, in which I conceive the valley to have originated."

Newport to Calbourne avd Alum Bay.From Newport, the road passes through the picturesque and interesting village of Carisbrook, and near the venerable castle, which stands on an eminence of chalk, on the left; ${ }^{*}$ and from thence to Calbourne, a little village, five and a half miles from Newport. In the vicinity of Calboume there are several quarries of freshwater limestone, where the stone is extracted for building, and agricultural purposes. The shells in the limestone of this part of the Island are generally in a much better state of preservation than those found at Binstead. The finest specimens in my collection, were obtained from the quarries at Calbourne, shalfleet (a village on the Yarmouth road), and on

* Carisbrook Castle, so interesting to the tourist, from the historical events with which it is associated, was founded in the time of Edward IV. The gateway, with: its round towers at the angles, and machicolated battlements, resembles the Castle gateway at Lewes, which was erected by John Earl de Warren, temg, Edward 111. See " $A$ Day's Ramble in and about the ancient Town of Lemes," p. 109.

The well at Carisbrook Castle is said to be 300 feet deep; it probably reaches the claalk-marl, which is in general the first water shed when the white elalk is perforated. 
Dodspit farm, about one mile and a half beyond Calbourne, in the same direction. In a pit opened in a ficld near the farm-house, at the latter place, * the limestone was peculiarly rich in those species of land and river shells, that are rare at Binstead. The snatl-shell (Ilelix globosus), figured Pl. II. fig. 7, and the bulimi, yaludina, limnei, and planorles (Pl. I.), are of a large size, and very perfect. Occasionally, the shells are preserved; but, for the most part, sharp easts alone remain. The limestone occurs in large concretionary masses, forming regular beds of moderate thickness in calcareous marl; the strata have a slight northerly dip.

From Calbourne, $f$ the road inclines to the left, and continues in a line nearly parallel with the chalk range, through Chessel, and Afton, to the foot of the downs that extend to the western extremity of the Island.

Soon after leaving Carisbrook, these hills are seen forming the distant horizon, their outline appearing as three distinct eminences. That on the left, is the chalk range of High-Down,

* In the summer of 1844.

+ Calbourne chur is is an interesting edifice, of early Norman architecture. There is a little im in the village, and if the visitor's time permit, a day may be well spent in examining the puarries in the loealities mentioned; a rich collection of the eocene freshwater fossils may with certainty be obtained. 
above Freshwater-gate, attaining an altitude of 700 feet; the middle eminence is the hill to the west of the rertical strata of Alum Bay; and that on the right, or north side, is Headon Hill, which is 400 feet high. The road passes within half a mile of Freshwater-gate, and winds up a steep ascent to the summit of the down, where a splendid and extensive prospect suddenly opens on the view. On the right is Headon Hill, separated from the eminence on the left, Alum Bay, by a deep chasm; and on the extreme left, is the lofty chalk ridge of High-Down, which extends restward into the sea, and terminates in the isolated wedge-shaped masses of chalk, called "The Needles." In the remote distance, on the opposite shore, the chalk cliffs, near Swanage, in the Isle of Purbeck, may be distinguished; and likewise the low line of tertiary cliffs on the Hampshire coast, by Barton and Hordwell. On the north-west brow of the hill, commanding a fine view of the entrance of the Solent sea, is "Grove's Hotel;" a very convenient resting-place, for a short sojourn.* From this spot there is a footfath along the north side of the chasm that separates Headon Hill from Alum Bay, which leads

* The intelligent landlord has a small collection of fossils, gathered from the neighbouring cliffs; it contained several interesting specimens, when I last inspeeted it. 
to the sea-shore, near the point of separation between the horizontal and vertical eocene deposits. Pl. VIII. is a view from the right hand side of the hill, about half way down, showing the vertical face of the chalk cliff which bounds the bay on the south, and extending westward, terninates in the Needles. The Isle of Portland is dimly visible in the remote distance.

The Const from Ryde to Alum Bay.-The stcam-packets from Ryde to Yarmouth and Lymington, pass sufficiently near the northern shore of the Island, to afford a general view of the outcrop of the strata in the cliffs and bays formed by the imroads of the sea, and at the mouths of the rivers and estuaries. The coast from Ryde to Cowes presents no features of particular geological interest. Here and there, slips or subsidences in the low cliffs have exposed beds of calcareous marl and freshwater limestone, covered by alluvial clay and loam, along the sea-boundary of Her Majesty's demesnes of Osborne, and of the grounds of Norris Castle.* Along the shore at

* Mr. Webster mentions that the arenaceous limestone of which the castle is built was quarried near the spot in these quarries, for ten or twelve feet below the surface, the strata consist of sand and imbedded waterworn blocks of limestune. Sir 11. Englefield states that in the low chif on the shore, the sime species of shells as in the limestone, occur as perfuct as if fresh from the river or lake. 
low water numerous fossil shells washed up by the sea are often to be met with.

On the north side of Gurnet Bay, about two miles to the west of Cowes, the cliffs are conposed of alternating beds of clay and limestone, the latter abonnding in freshwater shells (especially in potamides, Pl. II. figs. 2, 8, 9) and gyrogonites. In Thorney (or 'Thomess) Bay, similar strata are exposed, with layers of blue clay and sand, containing marine shells.* In several localities along the northern shores of the Island, as for instance, between Ryde and Cowes, and near Cowes, fluvio-marine clays appear on the sides of the sloping banks; but the exact stratigraphical position of these beds is concealed by regetation; they are probably the equivalents of the strata in the northern end of Whitecliff Bay, that contain an intermixture of marine and fluviatile shells.

Beyond Newtown Bay, are Hampstead Cliff's (about three miles east of Yarmonth), consisting of calcareous marls, with the usual fluviatile shells, in great abundance. In this locality, leaves of dicotyledonous plants, $\uparrow$ occasionally oceur ; and Mr. Prestwich has recently discovered great num-

- Mr. Lyell states that the entire buckler with the bones of a tortoise was obtained froun Thorness liay. (irol. Trans. vol. ii. p. 290.

+ Similar to those found in the plastic clay at Newhaven, in sussex, and "rourea in my "Fossils of the South Dawns," Pl. 1 . 


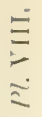

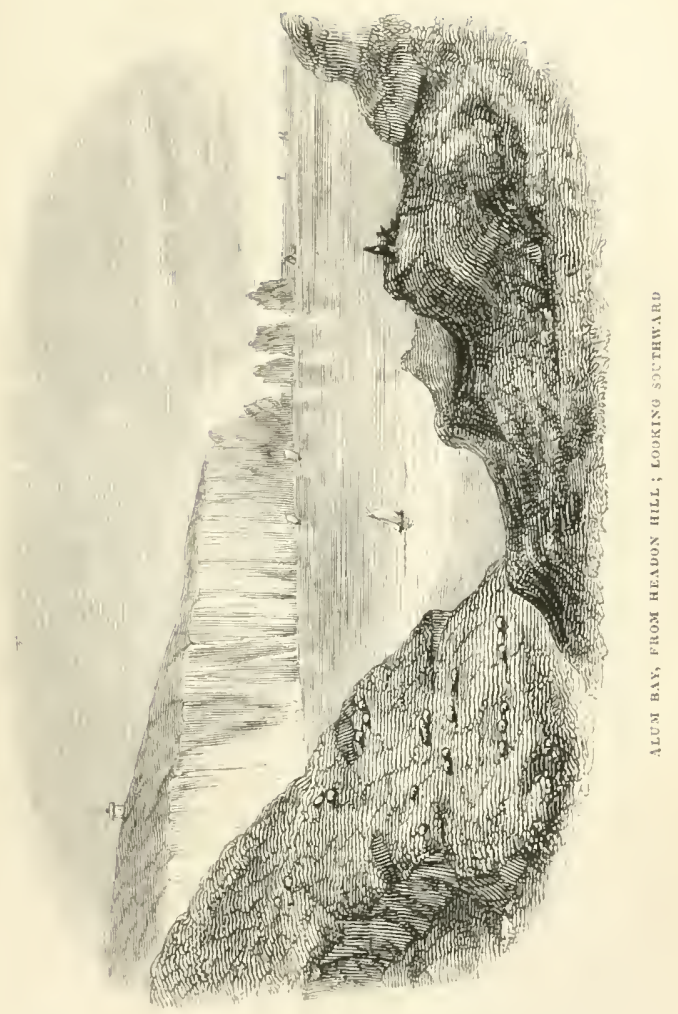



bers of an undescribed species of Cypris. 'The lower part of the cliff consists of sand containing freshwater with marine and estuary shells.

We next pass Yarmouth, and doubling the headland on which was Worsley's Tower, opposite Hurst Castle, enter Colwell Bay, where the cliffs exhibit alternations of marine and freshwater strata. In the fissure called Bramble Chine a thick bed of oyster shells is exposed, apparently in its original state, the valves being in contact with each other as when living; this appears to be the equivalent of the oyster bed observable at Whitecliff Bay. Many beautiful fossil shells may be collected in this locality. The elegant Cytherea incrassata (Pl. III. fig. 6), and Neritina concara (Pl. II. fig. 5), are found in sandy clay, in as perfect a state as if but recently thrown up by the waves. In Totland, or Tolland's Bay, similar sands, clays, and marls form the cliffs.

Headon Hill and Alum Bay.-We now approach Headon Hill and the richly coloured vertical strata of Alum Bay. The picturesque character of the dislocated masses of strata forming the face of the cliffs at Headon Hill is shown in $P l$. IX. The appearance of Alum Bay from the sea is imposing in the extreme, and is thus graphically described by Sir Henry Englefield:- 
"The scenery of this bay is very superior in magnificence to that of any other part of the Islancl. The chalk forms an umbroken face every where nearly perpondicular, and in some parts formidably projecting, and the tenderest stains of ochreous yellow and greenish moist vegetation, vary without breaking its sublime uniformity. This vast wall extends nearly a quarter of a mile, and is more than 400 feet in height; it terminates by a thin projection, of a bold broken ontline, and the wedge-shaped Needle Rocks, rising out of the blue waters, continue the cliff, in idea, beyond its present boundary, and give an awful impression of the stormy ages which have gradually devoured its enormous mass. The pearly hue of the chalk under certain conditions of the atmosphere and light is beyond description by words, and probably out of the power even of the pencil to portray.

" "The magical repose of this side of the bay is wonderfully contrasted by the tom forms and vivid colouring of the clay cliffs on the opposite sicle. 'These do not, as at Whitecliff, present rounded headlands clothed with turf and shrubs, but offer a series of points of a scalloped form, and which are often sharp and pinmacled. 1)еep fougered chasms divide the strata in many places, 
$\frac{3}{3}$

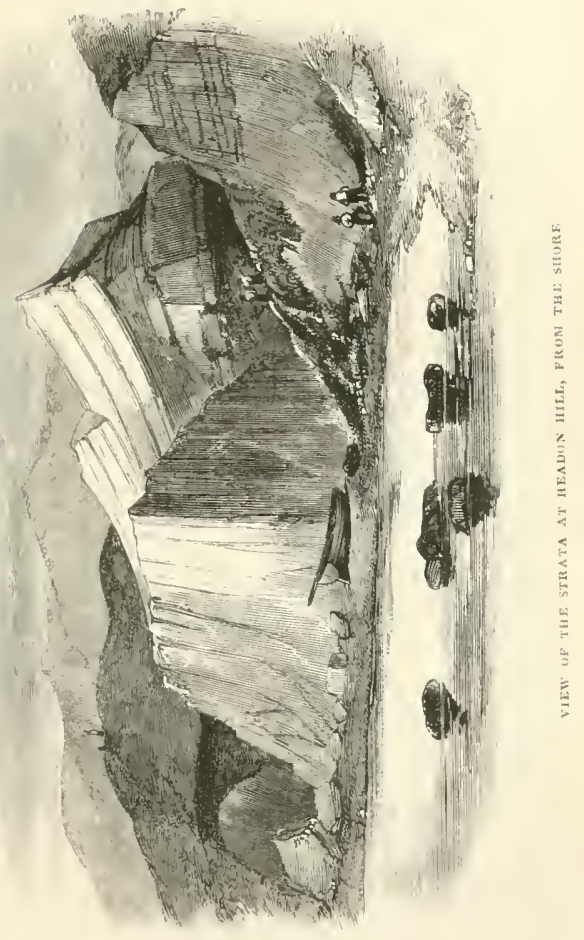



and not a trace of vegetation appears in any part. All is wild ruin! The tints of the cliffs are so bright and so varied, that they have not the aspect of anything natural. Deep purplish red, dusky blue, bright ochreous yellow, grey, nearly approaching to white, and absolute black, succeed each other, as sharply defined as the stripes in silk; and after rains, the sun which, from about 110011 till his setting in summer, illuminates them more and more, gives a brilliancy to some of these nearly as resplendent as the bright lights on real silk. Small vessels often lie in this bay for the purpose of loading chalk and sand, and they serve admirably to show the majestic size of the cliffs under whose shade they lie diminished almost to nothing." *

Geology of Alum Bay.-Although the unconformable position and dislocated state of the strata at Headon Hill, appear, at first sight, to present but little correspondence with the nearly horizontal freshwater deposits at Whitecliff Bay, and the richly-coloured and variegated stripes of sands and clays of the vertical cliffs of Alum Bay, still less to resemble the dull ochreous marine beds exposed in the breaks of the turf-covered slopes of that locality-yet a careful examination will soon

\footnotetext{
"Sir H. Englefield's “Isle of Wight," p. 81.
} 
convince the observer, that the geological characters of this north-western section of the eocenc strata, agree in every essential feature with those which engaged his attention at the eastem extremity of the lsland.* 'The diagram, lign. 11, will serve to show the close analogy between the deposits of Whitecliff, and of Alum Bay. This correspondence, and the extension of the same beds throughout the northern portion of the Isle of Wight, were ascertained, and distinctly enunciated by Mr. Webster, in his admirable memoir on the " Strata above the Chalk." i

From the incessant action of the sea on the base of Headon Hill, large masses of the upper lseds are continually falling down; and the face of the cliff is generally in so rumous a state, that the true stratigraphical position of the deposits is seldom risible. Repeated observations have, however, ascertained that the superior beds are nearly horizontal, but curve upwards as they approach the rertical strata, in the same mamuer as the corresponding layers at Whiteclift. In the sketch, $P$. IX., the upper masses of marl and limestone

- Mr. Prestwich has given accurate and detailed sections of Alum Bay, and Whitecliff, in juxta-position on the same plate, and thus admirably illustrated the relations of the strata in the two localities. Geol. Journal, No. 7.

† On the "Freshwater Formations in the Isle of Wiglit," \&e. Geol. Trans. vol. ii. p. 161, First Scries; 1811. 
ALUM BAY AND IIEADON HILL.

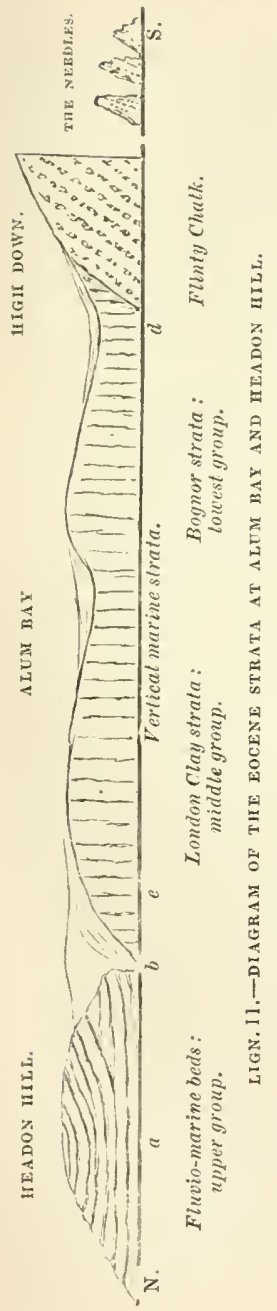

are lying in this position. The footpath that leads from Grove's hotel, down the chasm by which Headon. Hill is separated from Alum Bay, reaches the sea shore at the point marked b, in lign. 11, and which is indicated by the two upper figures in $P l$. IX. The visitor, therefore, upon arriving on the strand, has the horizontal freshwater series on the north, and the vertical marine beds on the south, flanked by the lofty chalk cliffs of High Down, and The Needles.

At Alum Bay, as at Whitecliff, the lacustrine and fluviatile deposits are the uppermost series (lign. 11, $a$,); the strata most decidedly marine, comprising the London clay, occupy a vertical position, and are the middle series (lign. 11, $c$,); the group denominated the Bognor strata, being the lowermost; then follow the mottled 
clays, and these abut against a bed of sandy loam, with pebbles and slightly rolled flints, that is in immediate contact with the chalk; as shown in lign. 11, d. The thickness of the eocene strata, from the chalk to the uppermost bed in Headon Hill, is stated by Mr. Prestwich to be 1660 feet; which is 300 feet less than the series at Whitecliff. The surface of the chalk in contact with the tertiary beds is much worn, and covered by a layer of sandy loam, containing pebbles, and rolled flints, which are invested with a coating of green earth; flints of this kind occur, also, at Newhaven, and in the fissures and sand-pipes of the Surrey and Sussex downs. Mottled clays and sand, with traces of lignite, as at Whitecliff, next appear, for a thickness of nearly 100 feet; and then the brown clay, with layers of septaria, abounding in the ditrupa; this is the lowermost bed of the Bognor rocks.* Becls of sandy clay with seams of pebbles, belonging to the same group, succed, and in some of the layers marine shells are numerons. A fossil crab, common at Sheppey,

* More than twenty species of shells, and some teeth of sharks, are enumerated by Mr. l'restwich, from this group. The most characteristic are Ditrnya plana, Pectunculus brevirostris, Turrilelta imbricalaria, Pholadomya margaritacea, Panopae intermedia, and Vermetus Bognorensis; all wellknown Bognor sluells, and mentioned in the carliest list of the fossils of that locality. See my "Gcology of the South-East of England." 
(Cancer Lecechii,) was found in this clay, by Mr. Bowerbank.

The variegated and deeply-tinted sands, marls, and clays, which impart so remarkable and brilliant an aspect to the cliff, are the next in order, and form a total thickness of between 700 and 800 feet. The alternations and variety of the vertical seams, or layers, are almost innumerable; the sands are of every shade of red, yellow, green, and grey; some are white, and others almost black: the clays are equally diversificd. Mr. Webster remarks, that "the variety of the vertical layers is endless, and may be compared to the vivid stripes of a parti-coloured tulip. On eutting down pieces of the cliff, it is astonishing to see the extreme brightness of the colours, and the delicacy and thinness of the several layers of white and red sand, shale and white sand, yellow clay and white and red sand; and, indeed, almost every imaginable combination of these materials." In the midst of this series, there are vertical layers of pebbles, and one thick stratum and many seams of lignite; in some of the clays, dicotyledonous leaves have been discovered, but no animal remains.

These richly-coloured strata are followed by clays with septaria, seams of pebbles, and a bed 
of green sand; the whole comprising a thickness of between 200 and 300 feet. In sone of these deposits, the usual London clay shells are abumdant, especially near the spot marked $c$, in lign. 11.* The dark sandy clay immediately on the north side of the chasm $b$, is also very prolific, and I have collected from it numerous choice specimens; nummulites, and other foraminifera, occur in some of the beds. $\dagger$

We now arrive at the foot of Headon Hill; and here the lowermost stratum visible on the beach is a pure white sand, which is largely exported for the glass manufactories; this is covered by a bed of yellowish clay. $\Lambda$ series of variously coloured sands, marls, and clays, with layers of friable limestone succeed. The predominating fossils are species of the freshwater genera, limneus, planorbis, melanopsis, potamides, cyrena, \&c., with which the reader is already familiar. But there are in some of the beds a few marine and estuary shells, as cytherea, ancillaria, corbula, Ec.; and a layer of oyster shells occurs, similar to that already noticed in the cliff in Colwell Bay. Within 50 feet of the top of the hill, there is

* The two figures in the foreground, $P l$. IX., are near this locality.

$\uparrow$ See Mr. Prestwich's "Memoir," for lists of the characteristic fossils found in each stratum, throughout the entire series of deposits. 
a stratum of reddish brown and mottled clay, with seams of lignite; and on this is superimposed whitish sand and marl, with interstratified layers of concretionary limestone, full of freshwater shells. A thick bed of gravel forms the alluvial covering on the summit of the hill.

Grological mutations.-From this sketch of the lithological characters and organic remains of the strata in this locality, it will be seen that the phenomena under review present a close analogy to those observable in Whitecliff Bay; the discrepancy being inconsiderable, and such as may have resulted from slight ehanges in the hydrographical condition of the district during the accumulation of the deposits. In both places there are proofs that the commencement of the eocene formation took place in a wide and open sea; the first accumulation of detritus on the water-worn surface of the chalk, being an argillaceous sediment, in which no animal remains were imbedded. The carliest group of fossils, the Bognor series, comprises the shells of marine mollusks that do not inhabit decp sea-water, but live in depths averaging from ten to twenty fathoms. This depth, as Mr. Prestwich observes, would be obviously inadequate to allow of the accumulation of detritus sufficient to form strata, which, when 
desiccated, are from 200 to 300 feet in thickness; and as the lithological character of the beds denotes a quiet and uniform deposit for a considerable time, and the fossils indicate an maltered condition of animal life throughout the same period, a tranquil and gradual subsidence of the seabottom must have taken place. The many humdred feet of sedimentary strata which were superimposed on the Bognor series, denote a subsequent subsidence to a great depth, to allow of the accumulation of the London clays, and sands. This epoch was followed by a gradual transition to an estuarine and lacustrine condition, as shown by the layers of fluvio-marine and freshwater shells. But the freshwater lake, or estuary, was subjected to occasional imptions of the sea; hence the beds of oysters, and interspersion of a few marine shells. A barrier was at length raised to the influx of seawater, and the sediments becane exclusively of a fluviatile and lacustrine character; this is proved by the prevalence of freshwater plants, crustaceans, and mollusks; and the presence of bones of terrestrial reptiles, and of mammalia.**

\section{Orgavic remans, - Alum Bay and Headon}

* This interpretation of the phenomena, is a concise expression of the generalization of Mr. Prestwich, whose admirable Menoir should be carefully studied by those who would enter fully into all the bearings of this interesting inquiry. See "Journal of the Geolog. Sociely," No. 7. 
Hill, will aftord the visitor an abundant supply of fossil shells, in great perfeetion and variety. Fignures of a few eharacteristic species, are given in $P$. I. and II.

Potomomya gregaria, Pl. II. fig. 1. Headon Hill.

Potamides conearus . - $\quad-2$

\begin{tabular}{|c|c|c|c|c|}
\hline — plicatus. . & - & - & 8. & 一 \\
\hline - ventricosus & 一. & - & 9. & - \\
\hline Planorbis cuomphalus & Pl. I. & - & 1. & - \\
\hline Limnens fusiformis . & 一 & - & 4. & - \\
\hline - longiseatus. & 一 & - & 3. & - \\
\hline Paludina angulosa . . & $\div$ & - & 6. & - \\
\hline Melanopsis fusiformis & Pl. II. & - & 3. & - \\
\hline - brevis. . & - & - & 4. & - \\
\hline Psammobia solida . . & Pl.III. & - & 1. & - \\
\hline Cytherea incrassata. . & - & - & 6. & 一 \\
\hline Corbula cuspidata . . & - & - & 2. & Alum Bily. \\
\hline Ancillaria subulata. . & - & - & 4. & - \\
\hline Neritina concara ... & Pl. 11. & - & 5. & 一 \\
\hline Ditrupa plana ... & Pl.JII. & - & 3. & 一 \\
\hline Panopæa intermedia . & - & - & 5. & 一 \\
\hline Cardita planicosta . . & - & - & 7. & - \\
\hline
\end{tabular}

Teeth of two species of Palreotherium ( $P$. crassum, and $P$. medium, were obtained by Mr. Prestwieh from Headon Hill; and I have seen a block of limestone, in which were imbedded sereral ribs of a small mammalian, from the same locality.

$\Lambda$ few species of crustaceans have been collected from the blue London clay, near the footpath. Gyrogonites, and impressions of dicotyledonous 
leaves, and lignite, are the only vegetable remains I have observed.

The fluvio-marine and freshwater shells, may be collected in great numbers from the fallen masses of strata that lie on the sea shore. In the marls, the shells of the limnei, planorbes, \&c., are well preserved; a chisel will be required to extract them. Thousands of the small species of potamides, melanopsis, \&c., will be found on the strand, having been washed out of the clays and sands composing the cliff. Very fine specimens of several species of marine shells may be obtained from the dark clay at the point marked $b$, in lign. 11. The spot which I have found most prolific, is the base of the cliff at the commencement of the footpath, near the sea-shore.

Yarmouth AND Irmington.-It is unnecessary to extend our remarks on the eocene formations of the Island; from what has been advanced, the intelligent visitor will readily comprehend the geological phenomena observable in the localities not comprised in our excursions. But before entering upon the examination of the next system, the Chalk, we would recommend a brief sojourn at Yarmouth; which is a convenient location for the geologist to visit 'Totland and Colwell Bays, Hampstead Cliff, and a few places on the opposite 
coast of Hampshire, which have long been celebrated for their organic remains.

The town of Lymington is situated on the western bank of the river of the same name, about four miles from Yarmouth, across the Solent Sea; to this place there are steam-packets from the Island, several times in the day. The town is spread over a low hill of tertiary strata. Near the brick-kilns on the eastern bank of the river, not far from the toll-gate, a deep exeavation has been made in beds of sand and clay, containing fossils.* An alluvial layer of gravel, ten feet deep, lies upon laminated blue and greenish elays, with interspersions of lignite, four feet in thickness. The next stratum is fine white sand, like that of Headon Hill, and Hordwell Cliff, six feet; and beneath is bhe (London?) elay, to an uncertain depth. In this clay I found several vertebræ and dermal bones of a crocodile, (Crocodilus Spenceri, $\dagger$ ) and a few fragments of bones of turtles. 1 observed no vestiges of shells; but learnt from the workmen that several kinds were oceasionally found, and also many bones, but none had been preserved.+

* This section was open in 1845 .

$\dagger A$ well-known species of the London clay, at Sheppey.

$\ddagger$ This brief notice is inserted to direct attention to a locality, hitherto, I believe, unexplored. I recommended the workmen to save every shell, bone, 
Christcunren Bay.-Christchmeh Bay is a semi-elliptical excavation, about cleven miles long, formed by the action of the sea on the Hampshire coast, which is here composed of an extension of the eocene stratia of the north-west part of the Isle of Wight; the two portions being now separated by the British Channel, which flows into the Solent Sea. The westermmost point of the bay, is Ilengistlury Head, near Christchurch; the easternmost, is the bar of shingle on which Hurst Castle is situated. Along the line of coast bounding the bay, there are several places in which sections both of the marine and freshwater strata are exposed; and Hordle, or Hordwell Cliff, near the little village of that name, has long been known as in inexhaustible mine of fossil relics. So long since as 1766 , a quarto work was published in illustration of the organic remains of this locality, with engravings, which, for aceuracy and artistic skill, far surpass most of the modern fignres of objects of this kind. **

Hordwell is about midway between Lymington and Christchurch; but from Yarmouth, in fine

and tooth, they might meet with; some future visitor will, perhaps, reap the beuefit of the suggestion.

* "Fossilia Hantoniensia collecta et in Musaro Britannico deposita, a Gustavo Brancler, Londini, 1766." "llampshire Fossils," \&c., with nine Jlates, containing 131 figures. 
weather, a boat offers the most convenient transport. Hurst Castle, which guards the narrow part of the Solent Strait, here not a mile across, is built on the extremity of a bar of shingle, that extends nearly two miles from the mainland, on the eastern part of Christchurch Bay. This bank consists of waterworn chalk-flints, and gravel, derived from the alluvial drift, which is so largely distributed over the coast district. "It is remarkable," as Sir Henry Englefield observes, "for its uncommon solidity; for it is merely a submarine cliff of shingle, 200 feet high, the depth of the channcl close to the castle being 33 fathoms; and the tide flows through it with a rapidity which, at certain times, no boat can stem; yet this natural breakwater has remained ummored for centuries." **

At the junction of the bar of Hurst Castle with the mainland, a low bank of gravel cxtends for about a quarter of a mile, and is succeeded by tertiary sands and clays, which gradually rise into cliffs 200 fect high; the first mile and a half being Hordwell Cliff, properly so called, which reaches to Long-mead. End. From this spot to a ravine formed by a stream at Beacon Bumu, a clistance

* See Sir II. Englefield's "Isle of Wight," p. 14, for many interesting remarks on the bed of the Solent. 
of half a mile, the cliff is named Beacon Cliff. The next two miles and a quarter is Barton Cliff, which is terminated by a stream at Cherton Bunny; and the remainder of the line to near Wuddiford, is Migh Cliff:* The alluvial gravel which forms the subsoil of so large a portion of this coast, appears at the top of the cliffs in a bed varying from twenty to fifty feet in thickness. $\gamma$

Strata of Hordwell Chiff.-The eocene strata in the coast sections have in no instance a vertical, or even highly inclined position, but gently dip to the cast. The Headon Hill series first appears, and constitutes the Hordwell Cliff; and the London clays and sands which rise to the surface at Barton Cliff, form the remaining portion of this line of coast. The strata of Hordwell Cliff' consist of altemating beds of marl, sand, and clay, often of a greenish colonr, with thin bands of indurated shell-marl full of the usual freshwater species. Mr. Searles Wood mentions that a thin seam of sandy elay, abounding in marine shells, is intercalated with these lacustrine strata a few paces

* These localities are aceurately described by Mr. Webster, in his sccond "Memoir," and are here introduced that the visitor may have no difficulty in finding the places hereafter mentioned as yielding certain sjecies of organic remains.

+ The stratitication of the coast, from the west of Cluristchurch to the chalk at studland lbay, in Dorsetshire, a distance of seventeen miles, is described by Mr. Lyell, in Cieol. Trans. vol. ii. p. 279. 
westward of a ravine that is situated half a mile from the village of Milford. It is about ten or twelve feet abore high-water mark, and extends many yards along the cliff.* The freshwater beds continue as far as Beacon Bumny, and in the upper part of that ravine, beneath the alluvial gravel, there is a bed of fluvio-marine sand, containing an intermixture of estuary and fluviatile shells, which may be traced to the eastward under the freshwater marl, to about 300 yards from Mead-end, where it disappears beneath the shingle of the beach. $\dagger$ 'This is succeeded by fine white siliceous sand, like that at the base of Headon Hill, forming a stratum from 60 to 100 feet thick. The London clay series next appears, and extends through Barton and High Cliffs. The upper portion of the beds consists of sandy clay of a dark green colour, like that at the base of the cliff in Alum Bay (marked $b$ in lign. 11), and abounds in marine shells; beneath are layers of septaria.

The strata at Hordwell Cliff are regarded by Mr. Lyell as the equivalents of the lacustrine beds which form the coast from Yarmouth to Gurnet Point, where the strata lose the character of an indurated calcareous marl, and are not unfre-

* The new "London Journal of Palæontology and Geology," p. 2.

† Mr. Searles Wood, loc. cit. 
quently of a bright green colour, like many of the layers of marl and clay at Hordwell. Detailed descriptions of the strata and their fossils are given by this eminent geologist in the second volume of the Cicoloy. Trans.; the following stunmary will be useful to the visitor:-

1. Allurial gravel, forming the top of the cliff; composed of lroken chalk-flints, with interspersions of sand and marl; thickness from 5 to 50 feet.

2. Fine white sand with greenish marl; - from 3 to 12 feet.

3. Green marls, with arenaceous clays; -16 feet. Contain lituminous wood and secd-ressels, with shells of the genera Helix, Unio, Melanopsis, Planorbis, and other lacustrine speeies. The lowest stratum is laminated marl, with layers of $C$ ymiles.

4. Sands and clays; -15 feet. Numerous shells of the mya gregaria. Lignite oeeurs in a layer of bituminons elay.

5. White calcarcous marl, largely constituted of aggregated freshwater shells; contains gyrogonites (see p. 109). It rests on a layer of black earbonaceous elay, with lignite; 1 foot.

6. Green unetuous and arenaceous marls; the lower portion consists of beds of pure white sand, with argillaceous sands;-15 feet. Numerous fluviatile shells. 'The white sand eontains abmdance of the shells of a small mussel (mya plana) in a very perfeet state.

7. Light green ealcareuus and sandy marls, with layers of a earbonaceous clay containing lignite;-22 fect. Nilmerous shells; and recl-vessels.

8. Green nuarl, carbonaceous clay and lignite, ferruginous clay, marl with vegrtable impressions, and green clay;9) feet. Freshwater shells, principally two or three specics of bivalves. 
9. White siliceous sand, withont shells; rises near Long-meurl Enel, and extends through Beacon and Barton Clift's to the middle of High Cliff:*

Near Boumemouth, a little watering-place on the Inampshire coast, between Hengistbury Head and Poole Harbour, dicotyledonous leaves, in a carbonized state, of the same species of plants as those found in Alum Bay (ante, p. 162), occur in a sandy marl, which traverses a cliff of fimly aggregated white sand. $f$ I am informed by William Smart, Esq., of Cranbourne (to whom I am indebtec for many interesting specimens of these fossil leaves), that the seam of marl is only four inches in thickness, and is limited to a few yards of the cliff, near the base; it is about midway between Bournemouth and Boscombe Cline.

In addition to the fossils previously discovered, Mr. Searles Wood has recently obtained the remains of five genera of mammalia and of one alligator, consisting of a jaw with all the teeth, of lizards, serpents, and birds. The following remarks on the geological phenomena observable at Hordwell Cliff are too pertinent to be omitted: "From the examination of the various strata

* "On the Freshwater Strata of Hordwell, Beacon, and Barton Cliffs, llampshire," by Charles Lyell, Esq. Geoi. Trans. vol. ii. p. 287, Second Srries.

† "Medals of Creation," vol. i. p. 193. 
which are exhibited in the beautiful section of Barton and Hordwell Cliffs, and of their peculiar fossils, one may follow in imagination the gradual silting $u$ ) of an estuary, and its passage eastward into a pure river deposit. Leaving the regular beds of London clay, which dip gradually to the eastward, and are lost in the beach below Beacon Bunny and Long-mead End, we meet with a stratum of sand in which marine and freshwater shells are intermixed, and one of clay containing leaves and seeds, with an extensive layer of lignite. Upon this is a bed whose organic contents display a still nearer approach to freshwater origin by the absence of the more decidedly marine genera, as oliva, natica, \&c., and the presence of cyrena, potomomya, \&e. in great abundance. Next comes a layer of brown sand, containing rolled fragments of bones of Palcotherium, 'Trionyx, \&e., which, from their appearance, may have been transported from a considerable distance. Over this rests a deposit of marl and white sand (No. 6 in Mr. Lyell's section), the latter in the state of an impalpable powder; in this were deposited nearly all the fossils above mentioned. 'The strata incline to the east at an angle of about $5^{\circ}$. The dircetion of the stream was no doubt westerly, that is, toward the marine beds; but at the spot 
at which I obtained so many interesting fossils there were indications of a contrary current; a circumstance, however, which nay very probably have depended upon a sudden bend in the river. 'The uniformly fine character of the sand, and the condition in which it was thrown down, would lead me to infer that the flow of the stream was extremely gentle. 'The gradual disappearance of marine species, such as are found at Long-mead End, and their replacement, as we proceed eastward, by species of freshwater origin, is just such a succession as we should expect to meet in tracing the course of a river upwards from its mouth." *

Hordwell fossils. - The numerous marine fossil shells which are obtained from this part of the coast of Hampshire are generally known as Hordwell fossils, but it is scarcely necessary to remark, that they almost entirely belong to the London clay strata, and are procured from Barton Cliffs. These fossils are most conveniently obtained from the low cliff near Beacon-bunny, and occur in greatest abundance in the upper part of the dark green sandy clay. There are generally blocks of the indurated portions of the strata on the beach, from which fossils may be extracted.

* The new "London Geological and Palaonlological Journal." loc. cil. 
It was from Barton Clift that Brander's fossils * were obtained. Sowerby's "Mineral Conchology" contains figures of numerous species and genera. $†$

The freshwater shells, and the remains of plants and land animals, are to be looked for in Hordwell Cliff, and in the fallen masses lying on the strand.+

In conclusion, it may be remarked that shells of those beautiful chambered cephalopoda, the nautili, are seldom, if ever, observed in the eocene strata of these cliffs, or in those of the Island; though the nautilus imperialis is not uncommon in the septaria on the westem coast of Sussex, and in the London clay at Sheppey.

* Fossilia Hantoniensia.

† A collection of Hordwell fossils, consisting of teeth of several species of sharks and rays, bones of turtles, and a great variety of shells, may be purchased at a reasonable price of JANE WEBBEn, dealer in fossils, Barton Cliff, near Christchurch.

$\ddagger$ The highly interesting specimens which have rewarded the recent investigations of $M r$. Searles Wood, will doubtless induce many a collector to visit the spot. The lower jaw of the Alligator Hantoniensis, a coloured plate of which embellishes the first number of the new "London Geological Journal," is one of the most splendid British fossils litherto discovered. Plate 2 of the same work contains figures of some of the mammalian remains discovered at Hordwell by Mr.S. Wood. 


\section{CHAP'TER VI.}

THE CIALK FORMATION-SUBDIVXSIONS OF THE CRETACEOUS SYSTEMRANGE OF THE CHALE IN THE ISLE OF WIGLT-THE UPPER AND LOWER CHALK-CHALK AND FLINT-SILICIFIED FOSSILS OF THE CHALK-THE FIRESTONE-TIE GALT-THE GREENSAND-SUMMARY.

The Chalk romution. - The different members of the Cretaceous system, though presenting considerable variety of lithological character, are yet essentially of the same type, and are linked together by a peculiar fauna, indicating the prevalence of a similar oceanic condition, throughout the rast period of time comprised in this geological epoch.

The features of a chalk district are so well known, that a brief notice of the physical geography of that part of the Island which is composed of the cretaceous strata, will suffice for our present purpose; and a reference to the map, I'l. XX., will render local details unnecessary. The rounded summits of the hills covered with short verdant turf-the smooth indulated outline of the downs, unbroken save by the sepulchrat 
mounds of the carly inhabitants of the comntrythe coombes and furrows ramifying and extending into the deep valleys which abruptly terminate at the base of the bills, and appear like dried up chamnels of rivulets and streams, though free from all traces of alluvial debris-thus bearing the impress of physical operations of which the agents that produced them have long since passed away-are phenomena familial to every one who has travelled over the downs of the southeast of England, and are displayed in striking characters in the chalk districts of the " beautiful Island." These features are restricted to the hilly districts of the white-chalk, and have resulted from the peculiar nature of the sedimentary detritus of which the strata comprised in the upper division of the cretaccous system are composed. For in the lower groups, clays, mark, sands, and sandstones prevail, and where these deposits approach the surface and form the subsoil, the country is broken and diversified, and the landscape presents a striking contrast with the down scenery; as may be observed in the picturesque district which flanks the escarpment of the chalk hills.

It may perhaps be necessary to remind the unscientific observer that these strata are but 
SUBDIVISIONS OF TUE CRETACEOUS SYSTEM. 175

an insulated portion of an ancicut sea-bottom, or in other words a mass of consolidated sediments formed in the profound depths of the ocean, in a very remote period of the earth's physical history. 'This detritus is made up of inorganic and organic materials: the former consist of the debris of the cliffs and shores which encompassed the ancient sea; of the spoils of islands and continents brought into the ocean by freshwater currents; and of chemical deposits thrown down from mineral solutions. The organic substances are the durable remains of animals and plants which lived and died in the ocean, and of fluviatile and terrestrial species that were transported from the land by rivers and their tributaries; the whole forming such an assemblage of sedimentary deposits as would probably be presented to observation, if a mass of the bed of the Atlantic 2000 feet in thickness were elevated above the waters, and becane dry land.

Subdivisions of the Cretaceous systei.The nomenclature of the chalk formation has undergone so many alterations, that to avoid confusion, it is necessary to define the precise meaning which the terms employed in the following pages are intended to convey. 


\section{GEOLOGỸ OF TIE ISLE OF WIGH'T,}

Chalk formation, and Cretaceous system, are synonymous terms, and designate the entire series of deposits between the $\mathbb{W}^{\top}$ ealden and the lowermost eocene stratum.

THe CraLk-signifies the white ehalk, ineluding 1 . the upper or finty ehalk; and 2. the lower or hard chalk, in which but few, if any, flints oceur.

Tue Firestone or Gladconite-comprises the chalkmarl, without any intermixture of green particles, as well as the limestone called in Sussex malm-rock; and the sands and arenaeeous marls and limestones full of green particles of silicate of iron, and termed by geologists the upper-green-sand and firestone. This group is the Glauconie crayeuse, of the French geologists.

Tris GALT - a deposit of stiff blne clay underlying the firestone, and eharaeterised by particular species of organic remains: called also Follstone marl, and Blue chalk-marl.

Tue Greensand-designates the series of clays, sands, sandstones, and arenaceons limestones; comprising the Iron-sand of Mr. Webster, the Lower-green-sand of Dr. Fitton (and of the map Pl. XX.); the Shanklin sands of the autbor; and the lower argillaeeous group, termed the Neocomian or A therfield deposits.

Range of tile Cialik formation in the ISLAND. - The various members of the cretaceous system, as previously stated, constitute the southern half of the Island; a range of chalk hills, broken through by the transverse valley of the Medina, extending from east to west, and 
separating the northern and southern districts. At Sandown Bay, we have seen the lower divisions of the formation successively appearing in the cliffs, in the anticlinal axis formed by the eleration of the Wealden strata; and in Compton Bay a like eleration of these deposits in a sinilar anticlinal system.

At Culver Cliff, and from High Down to Compton Bay, the chalk downs, consisting of highly inclined strata, form the sea-boundary; but in the micklle of the Island, this chain is flanked on the south by a denuded district of the lower strata, which expands several miles, and is succeeded by another system of downs formed of horizontal beds of chalk. 'This range extends from St. Catharine's to Shanklin Down, a distance of six miles, (see the Map and section, Pl. XX.). Thus in travelling from the northern part of the Island to the southern shore-as for example from Ryde to Sandown, or from Calboume to Brixton-vertical and highly-inclined strata of the flinty chalk are first passed over, and then the firestone, galt, and greensand deposits; the latter composing the sea-cliffs from Sandown to Atherficld, except where the fallen masses of the upper becls strewn along the Undercliff conceal them from observation. But in crossing the central district 
the chalk range is first traversed, and on the southern flank of the hills the firestone, galt, and greensand appear, and the latter extend southward sereral miles, and dip beneath another chain of hills capped with white-chalk strata; and on the south of this sccond range, the firestone, galt, and greensand ayain emerge and contribute to form the picturesque region of the Undercliff.

The Upeer and Lower Ciralk. - In pursuing this inquiry, I propose, before conducting the reader to the most interesting localities, to explain more fully the inorganic and organic composition of the principal deposits of the chalk formation; and thus afford a general view of the mineral characters and organic remains, of the strata that will come under review, in our excursions along the southern coast.

'The superior group of the cretaceous system consists of white limestone disposed in strata, which vary in thickness from a few inches to several feet. In the Lpper Chalk there are numerous parallel rows of siliceous nodules that occur at irregular distances from each other; and in some places there are sheets of flint (called talulur flint) between the layers of chalk, which extend over considerable areas. The cretaceous strata are also traversed by rertical and diagonal 
veins of the same substance. In the Lorer Chalk of England, flints are of very rare occurrence, and in general are altogether absent. The greatest total thickness of the white chalk strata is estimated at 1000 feet. The only metallic substances obscrvable are oxide of manganese in the state of dendriditical or arborescent markings in the chalk and flints, and sulphurets and oxides of iron. The most common form is the sulphuret of iron, or pyrites, in spherical nodules beset with crystals, which radiate from the centre, and when broken a shell or other foreign substance is very commonly found to be the nucleus. This substance often forms the casts of echinites, terebratula, and other shells, the surface of the mineral retaining sharp imprints of the original. The bones and scales of fishes and other animals imbedded in chalk, have invariably a ferruginous stain.

Chalk and flintr.-The pure white chalk is composed of lime and carbonic acid; it dissolves rapidly in hydrochloric acid, and leaves only a slight residum, consisting of silex and organic matter. A microscopical analysis shows it to be a mere aggregation of shells and corals, so minute that uprards of a million are contained in a cubic incl of chalk; the amorphous particles appear to be the detritus of similar structures. These organisms, 
for the most part, are the calcareous shields and chambered shells of the animalcules termed foraminifera; which swarn in inconceivable numbers in our present seas, and are daily and hourly contributing to the amount of sediment now forming in the bed of the ocean. *

The nodules and veins of flint that are so abundant in the upper chalk, have probably been produced by the agency of heated waters and vapours. The perfect fluidity of the siliceous matter before its consolidation, is proved not only by the sharp moulds and impressions of shells, \&c. retained by the flints, but also by the presence of numerous organic bodies in the substance of the nodular masses, and the silicified condition of the sponges and other zoophytes which swarm in some of the cretaceous strata.

Although silex or the earth of flint is insoluble in water of the ordinary temperature, its solution readily takes place in vilpour lieated a little above that of fused cast-iron, as has been proved by direct experiment; $\uparrow$ and similar effects are being produced at the present moment by natural causes. 'The siliceous deposits formed by the

" See " Medals of Creation," Article "Fossil animaleules," p. 21.5.

+ An aceount of Mr. Jefferey's important experiments will be found in the

"lieports of the British Association," for $18 \pm 0$. 
internittent boiling fountains, called the Ceysers, in Iceland, are well known ; * and in New Zealand this phenomenon is exhibited on a still grander scale. From the crater of the volcanic mountain of Tongariro, which has an elevation of 6,200 feet above the level of the sea, jets of vapour and streams of boiling water highly charged with silex are continually issuing forth, and dashing down the flanks of the rolcano in cascarles and torrents, empty themselves into the lakes at its base. As the temperature of the water diminishes, siliceous sinter is deposited in rast sheets, and incrustations of fint are thrown down on the extraneous substances lying in the course of these thermal streams. Silex is also precipitated by the boiling waters, in the state of stalagmitic concretions, and in nodules resembling in colour and solidity the flints of the English chalk. + The complete impregnation, and silicification (i.e. transmutation in to flint) of organic bodies is referable to an agency of this kind, as the eminent American mineralogist, $\mathrm{Mr}$. Dana, has clearly shown. + i

Silicified fossils of the chalK.-In many instances the organic remains in chalk flints, are

* "Wonders of Creology," vol. i. p. 84.

† Dr. Diefienbaclı's "New Zealand."

\$ A American Journal of Science," for January 1845. See also, "Notes of a Microscopical Examination of Chalk and Flint," by the Author. Annuts Nat. Hist. 1845. 
simply incrusted by silex: such is the state of numerous sponges which are as it were inrested by the flint, and have their pores and tubes filled by the same material; the original tissue appearing as a brown eart!. In other examples the sponge has been enveloped by a mass of liquid silex and has subsequently perished; in this manner have been formed those hollow nodules, which on being broken present a cavity containing only a little white powder, or some fragments of silicified sponge: while in other instances the cavity is lined with quartz or chalcedony. It frequently happens that part of the zoophyte only is permeated by silex, while the other portion is a friable calcareous substance imbedded in the chalk. Certain zoophytes (Tentriculites, see "Medals of Creation," rol. i. p. 271,) are often found in this state; hence the protean forms of the flints that have been moulded on portions of these organisms.

But there are innumerable flint nodules which exhibit no traces of spongeous structure; and veins, dikes, and sheets of tabular flint that may be regarded as pure, and free from organic renains, excepting such as must inevitably lave become cutangled and imbedded in a stream of mineral matter flowing over a sea-bottom. 
A sponge or other organic body often forms the nucleus of the flint nodules, and the original substance of the fossil is generally transformed into silex, and yet the most delicate structure preserved. In other examples the organisms enclosed in the flint lave undergone no change, but appear as if immersed and preserved in a semitransparent medium. Such is the state in which the foraminiferous shells (rotalice, textilaria, "Medals of Creation," p. 232), and minute corals, often occur.*

Fossil animalcules.-For the most part the microscopic shells in chalk and flint are filled with amorphous mineral matter; but recent observations have shown, that in numerous examples the shell contains the body of the animal, in some instances silicified, but in others in the state of a dried animal substance, like the ink-bag of the cuttlefish in lias, $f$ the soft parts of cephalopoda in clay, and the capsule of the eye and the membranes of the stomach of certain fishes, in chalk. $\S$

* An exquisite example of this kind was discovered by the Marquess of Northampton in a chalk flint from Brighton In a polished slice of this specimen, presented to me by his Lordship, there are branches of several delicate corals (pustulopora, relepora, idmonea, "Medals," p. 284,) and foraminifera, as perfect, and unaltered in appearance, as if immersed in glass.

† Dr. Buckland, "Bridgwater Treatise."

$\ddagger$ Professor Owen on the Beleninite.

$\S$ "Wonders of Geology." 
184 GEOLOGY OF THE ISLE OF WIGH'.

In flint, such specinens are by no means rare, and from the semi-transparency of that mineral are easily detected. The annexed figure (lign. 12) represents the body of a rotalia in its shell (highly magnified) imbedded in an atom of flint, in which there is another example, and some other organisms. The shells of Rotalice in the chalk also

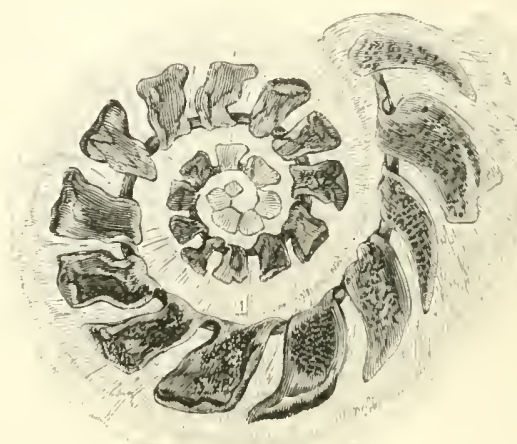

J. Dinkel, del.

LIGN. 12.

THE SHELI, OF A ROTALIA;

Containing the fossilized remains of the body of the animal; in flint; highly magnified.*

contain the body of the animal; and by dissolving the chalk and the shell in weak hydrochloric acid,

* Speeimens of the Rotaliæ, Xanthidia, and other minute fossil organisms of the chalk and flint may be obtained of Mr. Topping, the well-known microscopic artist, No. I, York Place, Pentouville 1lill, London. See "Medals of Creation," vol. i. pp. 78,244 , for instructions how to prepare fossils for the inicroscope. 
and immersing the residue in a transparent medium (Canada balsam), the soft parts are as distinctly seen, as in a recent dead specimen.**

So little attention has been paid to the white chalk fossils of the Island, that a few of the common species of terebratula, spondylus, and echini; tecth of sharks; ventriculites, choanites, and other zoophytes, comprise almost all the specimens I have observed in private collections; but there can be no doubt that were the quarries and natural sections diligently examined, an interesting series might be obtained. $\downarrow$

The Firestone.+-The lower white chalk, in some places, as at Dover, gradually passes down into a bluish-grey chalk, and the latter into an argillaceous limestone, well known by the name of chalk-marl. In other localities the chalk maintains its purity to its junction with the marl. An intermixture of green sand characterises the latter in many districts, and this

* A Memoir on this subject, by the author, will appear in the third Part of the Philosophical Transactions for 1846.

+ Figures and descriptions of British chalk fossils are given in my "Fossi]s of the South Downs," "Wonders of Geology," and "Medals of Creation," and "Gcology of the South-East of England;" in Sowerby's "Mineral Concliology," Mr. Lycll's " Elements of Geology," and in Parkinson's "Organic Remains of a Former World."

$\ddagger$ The name Upper-green-sand, generally given to these arenaceous marl beds of the chalk formation, has been proluctive of su much confusion, that the provincial term, Firestone, however inapplicable as a descriptive term, seems preferable. 
variety passes into a hard calcareous sandstone, termed in Surrey Firestone. Deposits of green sand, with layers and concretions of ehert, and seams and nodules of coarse chalcedony, characterise this group in some districts, and are largely developed in the Undercliff. The bands of siliceous limestones and calcareous sandstones, with. reins and nodules of chert which appear in the inland cliff of that distriet, belong to this division of the cretaceous system.

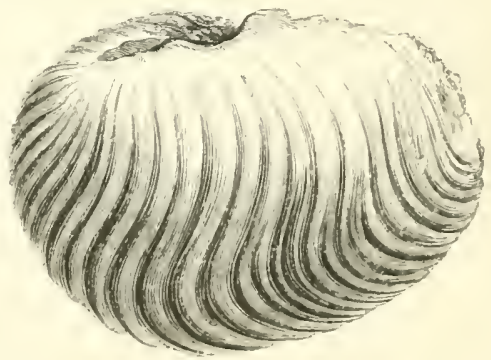

IIGS. 13.

NAUTILUS ELEGANS.

From the Chalk-marl, near Ventnor.

The chalk-marl in most localities abounds in fossils; it contains numerous species of Ammonites, NautiJus, Turrilites, and other cephalopoda, which are either of excessive rarity, or altogether absent in the upper chalk strata. The Nautilus and Ammonites 
figured in the subjoined lignographs, 13, 14, 15, are characteristic species of the chalk-marl. 'The

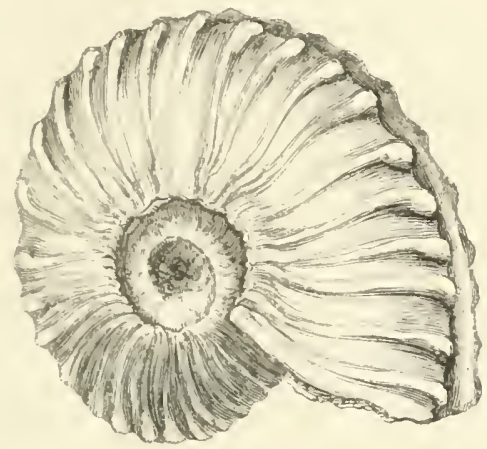

EIGX. 11 . AMMONITES VARIANS.

From the Chalk-marl, near Bonchurch.

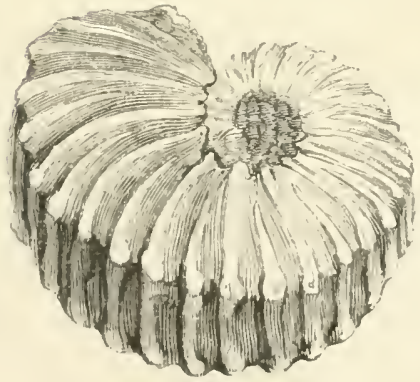

KIGN. 1:, AM\$ONITES MANTELLI.

From the Chalk-marl, near Bonchurch.

specimen of $N$ autilus elegans, lign. 13, is a young shell: this species is often two feet in circumference. 
ISS GEOLOGY OF TIIE ISLE OF WIGHT.

Some localities of the Island are extremely prolific in organic remains, and have yielded to the researches of Capt. Ibbetson an interesting series.* J. M. Saxby, Esq. of Bellerue House, has recently collected many species from Bonchurch and V'entnor. A list of the fossils obtained by Dr. Fitton from these strata, chiefly from the cliff at Western Lines, is given in Geol. Trans. rol. iv. p. 20\%.

The GaLT. - This is a deposit of very dark blue marl, having an arerage thickness of 100 feet; the clay in many places has a large intermixture of green sand, and is traversed by thin layers of red marl. It presents no distinctive mineral aspect, but is characterised by the abundance, peculiarity, and state of preservation of its fossils. Numerous species of Ammonites, Hamites, and other cephalopoda, with their nacreous shells entire, and bivalves and gasteropodous univalves seldom, if erer, found in the strata above or below, may be collected from most localities where the Cialt is exposed in natural or artificial sections of any considerable extent. This deposit is seen on each side of the anticlina.s on the southern coast, and in some parts of the Underchiff, near Ventnor

- There is a good suite of marl fossils belonging to this gentleman exhibited in the lsle of Wight model-room of the Polyteehnie Institution of L.undon. 
and Bonclurch; I believe only a few fossils have been observed.

The greensand. - This division of the cretaceous system comprises numerous alternations of argillaceous and arenaceous strata of great thickness and extent, constituting an important group, which is well defined by the fossil remains.

It consists of cherty and calcareous sandstones, and sands of various colours, white, green, grey, red, brown, fawn, yellow, and ferruginous: the predominance of the green sands in some districts having suggested the term now employed to designate the group. It was called the iron-sand where the ferruginous character predominated, as in the Isle of Wight.* Thick beds of sandy and ferruginous clay, are intercalated with the arenaceous strata. The Greensand is separable into three divisions, as was first shown by Dr. Fitton, whose indefatigable and successful labours have so largely contributed to the elucidation of the characters and relations of the deposits between the chalk and oolite in England.

In the upper or Shanklin sand series, the strata

* The whole series is described by Mr. Webstcr, as the Iron-Sand, in his various memoirs on the geology of the lsle of Wight; and the unfortnnate application of this term to the sands of the Wealden districts of Surrey, Kent, and Sussex, retarded. for a long period, the true exposition of the nature and relation of those deposits. 
are chiefly ferruginous sands with iron-stone and concretions of chert, with dark clays in the lower part. The middle group is marked by the prevalenee of green and grey sand with beds of calcareous sandstones, and cherty limestone ealled Burgate-stone in Surrey, and Rag in Kent. In the lowermost or Atherfield series, the argillaceous character predominates. The beds of sand abound in peculiar fossils, and the concretionary limestones and sandstones contain characteristic organic remains. 'This general notice will suffice, as the details of the sections exposed along the southern coast of the Island, have been worked out by Mr. Webster, Dr. Fitton, Capt. Ibbetson, Professor Forbes, and other eminent observers, and are published in the Transactions and Journal of the Geologieal Society.

The following species of shells from the Greensand of the Isle of Wight, are figured in Plates $I V$. and $V$.

Corbis romugrta, $P l$. IV. fig. 1. This and the following figure represent lut one side of the bivalves, and therefore lo not convey an idea of the form of the entire shell; but the markings on the surface are distinetly given, as affording the easiest comparison for the inexperienced collector. 'T'igonie cenclute, Pl. IV. fig. 2. This shell is so remarkalle hoth in its form and seulpture, as to be easily identificel.

Anvilliu ane ps, l?. W. fig. 3. Entire beds of this shell 
oecur in some of the sauds at A therfield. The sprecies is generally more elongated than in the individual figured. I Tenus striato-costate, Pl. IV. fig. 4. A small and easily recognised shell.

Venus parve, $P l$. IV. fig. 7. In iron-stone nodules in Shank. lin cliff.

Arce raulini, $P l .1$ V. fig. 5.

Perna mulleti, $P l$. IV. fig. 6. This large and remarkable bivalve, ocenrs in great numbers in a thick layer immediately above the junction of the greensand with the wealden, at Atherfield and Sandown-bay. The prolonged linge-line is commonly broken off in extracting the shells from their matrix, mnless due care is taken.

Thetis minor, $P l$. V. figs. 1, 2. These are only casts in ironstone, the shell having perished. They are abundant in the concretions from the ferruginous sand on the top of the cliff at Dunnose Point, that liave fallen on the shore.

Gryplea sinuata, $\mathrm{Pl}$. V. fig. 3 . This shell attains a large size; speeimens are numerous along the shores at Shanklin, Ventuor, and in Compton-bay; being washed out of the eliffs of greensand.

Terebrutule sella, $P l$. V. fig. 5. This shell in a very perfect state is found by hundreds in the greensand at Atherfield, se. It occurs in great numbers in the greensand-pits at Faringdon in Berkshire.

Nucula scapha, $P l$. V. fig. 6 . This and the following small shells abound in the Atherfield Crackers-roek.

Tornutella albensis, $P l$. V. fig. 4.

Tratica rotundatu, $P l$. V. fig. 7 .

Pterocere retusa, $P l$. V. fig. 8.

Rostellaria robaldina, $P l$. V. fig. 9.

Cerithium turriculutum, $P l$. V. fig. 10.

Scaphites gigas, $P l$. V. fig. 11 . This shell attains a large size; specimens two feet long are sometimes found. The colleetions of Capt. Ibbetson and Mrr. Bowerbank contain splendid examples. lmperfeet speeimens of the spiral part have been described under different generie names. 
Sumary. - The character of the cretaceous system, as shown by these investigations, is that of an ocean-bed formed in a vast basin by successive aceumulations of sedimentary detritus, transported by currents, and thrown down in the tranquil depths of the sea; arenaceous and argillaceous deposits prevailing in the lower, and cretaceous in the upper division of the series; periodical intrusions of heated fluids charged with silex having taken place at uncertain intervals. The fossils prove that the ocean swarmed with innumerable beings of the usual orders of vertebrate and invertebrate marine organisms, belonging for the most part to species and genera now unknown; and in the chalk are seen for the last time that numerous tribe of cephalopoda, the Ammonites, of which not a single species is known either in the tertiary strata, or in any more recent deposits: so far as our knowledge at present extends, with the chalk the whole race of Ammonites disappeared.

With regard to the vegetable kingdom of the cretaceous period, the presence of numerous fuci attests the nature of the marine flora; and the fragments of drifted coniferous wood, fir-cones, stems and leaves, which are found in the flint and chalk in some localities, prove that the dry land was clothed with pine-forests, and eycadeous 
plants. 'The occasional discovery of bones and teeth of reptiles, shows that the islands and continents were tenanted by oviparous quadrupeds.* Of birds and mammalia not a vestige has been discovered.

* It is wortlyy of remark, that fossils and fragments of other rocks are very rarely found in the white chalk. Pebbles of quartz and sandstone are the only extraneous minerals of frequent occurrence. A solitary instance of fragments of green chlorite schist, in chalk marl, near Lewes, was discovered by myself some twenty-five years ago. My friend, Henry Carr, Esq. C. L.. has recently found some water-worn pieces of fossil wood imbedded in white chalk, from the cutting of the railway he is constructing between Epsom and Croydon. This wood, in its mineralogical character and organic structure, is unquestionably identical with the well-known fossil wood of the Portland oolite, and I have no doubt is a portion of a mass that was drifted into the bed of the cretaceous ocean. 


\section{CHAPTER VII.}

FRON YARMOUTII TO FRESHWATER-GATE - SCRATCHELLS'BAY - YERTICAL CHALK STRATA-SIATTERED FLINTK-THE CHALK DOWNSCAUSES OF THE PRESENT CUNFIGURATION OF TIIE CIIAL HILLSFROM FRESIWATER-GATE TO COMPTUN-BAY-GEOLOGICAL SECTIONS OF THE SOUTHERN COAST-PEBBLES AND SHINGLE.

From Yarmouth to Freshwater-gate. - In resuming our survey of the geological phenomena of the Isle of Wight, we proceed from Xarmouth to Freshwater-gate, on the south-western shore. In a direct line, through the transverse valley of the river Yar, which rises from the northern foot of the downs, the distance but little exceeds two miles and a half; but the road makes a considerable detour to the left, romnd the eastern border of the estuary. Passing over a gently undulated comitry of the fluvio-marine eocene strata, and ascending a steep acelivity of tertiary sands, we cross the narrow tract of highly inclined chalk which unites Afton-Downs on the east with High 
$\dot{a}$

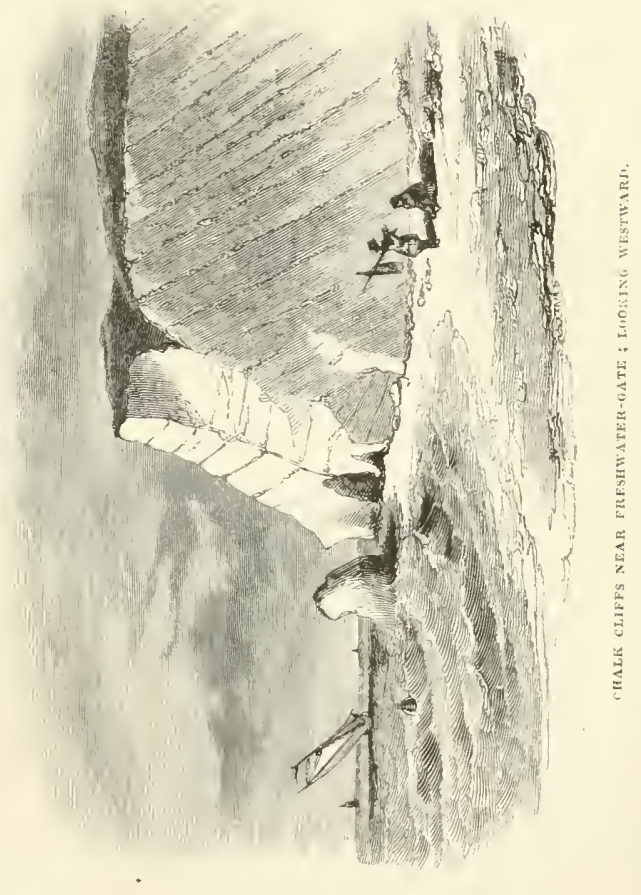



Down on the west, and reach the southern coast by an opening in the chalk cliffs that extend from Compton Bay to The Needles.

Immediately on our left are some detached pinnacles of chalk, jutting into the sea, and on the right the fine section of highly inclined strata of chalk and flint represented in $P l$. X. At the base of this headland is the entrance to a considerable excavation in the cliff, produced by the erosive action of the waves on the lower beds of chalk; some perpendicular masses of the harder portions of the rock worn into irregular columns support this natural archway, which is known to tourists as "The Cave." It extends 120 feet into the cliff, and is between thirty and forty feet high; it is well deserving the notice of the geologist, for the displacement the strata have undergone is here strikingly displayed.

From Freshwater-gate to the Needles, a distance of three miles, the cliffs present a succession of mural precipices of chalk, from 400 to upwards of 600 feet in height. The face of these cliffs when seen from the sea at a short distance

* The description and beautiful illustrations of the picturesque features of the scenery along this part of the coast, in Sir H. Englefield's "Isle of Wight," render it unnecessary to dwell upon this inviting subject. Some of Mr. Bartlett's views of these chalk cliffs, in Barber's "Illustrations," are very accurate and effective. 
has a remarkable appearance, from the rows of flints, which score the surface of the white rock with fine dark parallel lines, rumning in an oblique direction from the top to the bottom of the section. In some places the lines are mrdulated, in others arched, and near the snmmit of the cliff towards Alum Bay, they are very flexuous, and bent down, as if a heavy mass above had pressed upon the upper ends of the layer's of flints, while the chalk was in a plastic state. The general inclination of the beds of this part of the range is nearly vertical on the north, with a gradually decreasing angle towards the south.

Scratchela's Bay.-The most stupendons line of chalk cliffs is that termed the Main-bench; and beyond is Seratchell's Bay, which is bounded by the Needles. The aspect of the scene in this bay is romantic in the extreme; in the face of the cliff, from the destruction of the lower beds of the bent strata, a magnificent arch 800 feet high has been produced, and forms an alcove that overhangs the beach 150 feet.*

The well-known pinnacles of chalk, called The Needler, are isolated masses of the extreme western

* In calm weather Scratchell's Bay and the Needles may he safely visited in the pleasure-boats to be hired at lireshwater-gate; parties generally land on this strip of shingle to view the stupentlous arch above. A splendid view of the bay by Mr. Webster is griven in PI. 25, of Sir 11. Englefield's work. 
point of the middle range of Downs, which have been produced by the decomposition and wearing away of the rock in the direction of the joints or fissures, with which the strata are traversed. The angular or wedge-shaped form of these rocks, has resulted from the highly inclined northward dip of the beds of which they are composed.

Vertical chalk strata, - To the late Sir Henry Englefield belongs the merit of having first observed and directed attention, to the highly interesting phenomena, occasioned by the disruption and elevation of the eocene and cretaceous formations, which are so remarkably displayed in the Isle of Wight; namely, the vertical position of the strata, and the shattered condition of the flint nodules, though still imbedded in the solid rock. These appearances may be conveniently examined in the cliffs before us.

The chalk forms parallel beds or strata varying from two to five feet in thickness, which are commonly separated by layers of flint nodules imbedded at irregular distances from each other; there are also a few nodnles dispersed indiscriminately in the mass. The dip of the inclined strata as previonsly stated is in general from $70^{\circ}$ to $80^{\circ}$ : but many beds throughont a con- 
siderable extent are quite vertical (see Pl. XIII.). The parallelism of the cretaceous strata, and the absence of sand, gravel, and other coarse detritus, denote that the deposition of these ealcareous sediments took place in tranquil water, and remote from sea-eliff's and shores. Where a large extent of the cliff is exposed, the face of the chalk is seen to be traversed by fissures or joints at right angles to the planes of stratification; some are vertical, others diagonal, and erossing in various directions, divide the entire mass into irregular portions; in some localities these partake of a rhomboidal form.* These fissures have evidently been produced after the consoliclation of the strata in which they occur, for where they traverse the horizontal layers of flint nodules, some of the latter are often displaced; and very commonly a fault, or interruption of the parallelism of the opposite sides of the ehasm, has taken place, either from the elevation or the subsidence of one of the separated masses. In many instances the fissures are filled up with flint, which occupies the ereviee wholly, or partially, throughout its whole extent, forming large sheets of pure silex, varying in thickness from that of

* Mr. Webster partieularizes the large clalk-pit on the south side of Arreton Down near the top, not far from Ryde. In this quarry the strata are inclined at an angle of $80 \mathrm{deg} . ;$ and both the tabular flints and the nodules are completely shivered. 
pasteboard, to two or three inches. These siliceous veins often consist of two plates with loose calcareous detritus between them, as if the flint had flowed down or oozed from the sides of the fissures; and this detritus is frequently composed of shells of microscopic foraminifera. In other cases the cavities are filled with marly and soft chalk; and in many instances they are empty, but their sides are lined with crystallized carbonate of lime. These fissures are evidently referable to a period long antecedent to the elevatory movements which broke up the chalk strata, and hurled them into their present position, for they traverse the horizontal layers; and the subsequent introduction of flint, proves that they were the effect of submarine movements, which took place while the physical condition of the bed of the cretaceous ocean remained unchanged. This fact also corroborates the inference, that the eruptions of steam or vapour charged with silex into the chalk, occurred periodically, and sometimes at long intervals.

But there are numerous chasms and fissures in the strata which clearly belong to a very different epoch; to a period geologically recent, when the now upper surface of the chalk was rent by earthquakes, and the mountain 
masses of the cretaceous systen atequired their present position and configuration. For these fissures are invariably connected with the surface, and are more or less filled with clay, sand, gravel, and waterworn flints, from the alluvial debris that forms the subsoil of the country. These appearances may be observed in the chalk underlying the bed of gravel and clay, on which the Albion Hotel at lreshwater-gate is situated.

Sirattered Flints.-Upon carefully extracting a flint nodule from this cliff, it retains its original form; but upon examination it will be found "shattered in every direction and broken into picces, varying in size from three inclies in diameter down to the minutest fragment, and even into an impalpable powder. The flints thus shivered, as if by a blow of inconceivable force, retain their form and position in the bed. The chalk elosely invests them on every side, and till removed, nothing different from other flints can be perceived, exeepting fine lines indicating the fractmoe, as in broken glass; but when moved, they fall at once to pieces. 'The fragments are as sharp as possible, and quite irregular, being certainly not the offect of any peculiar crystallization or internal arrangement of the material, but solely attributable to external violenee." Such is the 
description of this remarkable phenomenon given by Sir H. Englefield thirty years since.* 'The tabular and plated flint in the fissures is also shattered in a similar manner. The nodules in the regular layers are invariably in this state, in every locality of the vertical and highly inclined chalk; but the separate nodules in the middle of the strata are entire; and in the horizontal beds, as for example, on St. Catherine's, Boniface, and Shanklin Downs, all the flints are unbroken. This shattered condition of the flints has doubtless arisen, as Sir Henry Englefield suggested, from the concussion caused by the upheaval and disruption of the once horizontal cretaceous deposits. The disturbing force, though in many instances producing flexures in the strata, was clearly exerted violently and suddenly, and in such manner as to shatter the flints without dislodging them from the chalk. From the insulated nodules being generally entire, it would seem that the greatest violence

* Sir H. Englefield's "Isle of Wight," pp. 20, 21. The following places are enumerated as exhibiting this phenomenon very distinctly :-Alum Bay-Pit south of Carisbrook Castle, and near Carisbrook town-Arreton-pit-BradingDown-pit-Brading Shute-Culver Cliff. Shattered flints are oceasionally met with in some parts of the Sussex and Surrey chalk. My attention was first directed to the subject in 1820, by a paper of Sir $\boldsymbol{H}$. Englefield in the "Linnean Transactions;" and a chalk-pit on the top of Nortli-street, Brighton, now filled up, and the area built over, presented a fine example, for every flint, though retaining its form, was reduced to fragments. See the

"Fossils of the South I)owns," p. 152. 
204 GEOLOGY OF TIE ISLE OF WIGHT.

of the sluock wis exerted in the direction of the lines of stratification.

Mr. Webster, in describing the shivered flints in the chalk at Handfast-point, on the Dorsetshire coast. remarks that the nodules are not only much shattered, but appear ats if they had been redueed to atoms while the rock was yet in a soft stute, for the fragnents are in general separated from each other, with chalk between thems; and the broken pieces of flint are at such distances, that it is impossible to conceive by what means they could have been so far separated, had the chalk been solid at the moment of their fracture. 'The bent condition of the strata at Handfast-point, which will be described in a future page, attests the plastic state of the chalk at the period when its uphearal took place.

Tue Chalk nowss. - We now leave the seashore to ascend the hill, and proceed along the foot of $\triangle$ ftom Down to Comptom Bay, which is about a mile distant. 'The western part of the central range of downs extends from the Needles Cliff to Motteston Down, which is 700 feet high, and is a narrow ridge nine miles in Jength, with steep declivities on each side; that on the north arises from the higlily-inclined dip of the strata ; that on the south is produced by the precipitoms 
escarpment formed by the sudden termination of the cretaceous beds where they rise to the surface. The summits of this range command views of great extent and picturesque beauty, for both the northern and southern shores are distinctly visible.* From the Needles Down, may be seen on the north Tollands, Colwell, and Yarmouth Bays; and on the south, Freshwater and Compton Bays, and the di tant line of coast. The eastern portion of this chalk range, from Arreton Down to Culver Cliff, a distance of seven miles, is of the same character. $\uparrow$

* A graphic description of the scenery from this range of hills is given by Sir H. Englefield, chap. iii. The view from Buccomb Down, looking over Carisbrook Castle and Newport in the vale beneath, is very splendid; that from Arreton Down is equally fine.

t The view from Ashey sea-mark, which is situated on this part of the chalk-bills between Arreton and Brading Down, is thus described by the Rev. Legh Rjchmond:-

"Southward the view is terminated hy a long range of hills (Shanklin, Wroxall, and Appuldurcombe, ) at about six miles distant. They meet to the westward another chain of hills, of which the one whereon $l$ sit forms a link, and the whole together nearly encompass a rich and fruitful valley, filled with corn-fields and pastures. Through this vale winds a small stream for many miles; here and there lesser eminences arise in the valley, some covered with wood, others with corn or grass, and a few with heath or fern. One of these hills is distinguished by a church ( $N$ ew church) at the top, presenting a striking feature in the landscape. Villages, churches, country seats, farm-houses, and cottages, are scattered over part of the southern valley. In this direction also appears an ancient niansion (Knighton), embellished with woods, groves, and gardens. South-eastward is a broad expanse of ocean, bounded only by the horizon. More to the east, in continuation of the chain of hills on which 1 an sitting (Ashey) rise two downs (Brading and Iaverland hills), one beyond the other; both are covered with sheep, and the sea is just visible over the furthest hill, as a terminating boundary. In this point are seen ships, some of which are sailing, and 
Ascending Afton Down, the summit of which is crowned with a group of tumuli, the views along the southern coast are lovely in the extreme. When almost half way up the acclivity, the landscape to the west displays a magnificent coup dwil of the romantic scenery of Freshwater and Scratchell's Bays, and The Needles; and that to the east affords a view of Compton Bay, Brook Bay, and the coast, till it is lost in the remote distance.

\section{Cause of the configuration of chalk Downs.} - From what has been stated as to the composition of the white chalk, and the formation of the strata, the cause of the external configuration of the verdant downs we are now traversing appears sufficiently obvious. If we examine the spots where the turf las been removed by the flintdiggrers, we perceire immediately beneath the

others lying at anchor. On the north the sea appears like a noble river (the Solent), varying from three to seven miles in breadth, between the banks of the opposite eoast aud those of the island. Immediately underneath me is a line woody district, (liversified by many pleasing objects. Distant towns ( Portsmouth and (iosport) are visible on the opposite coast; and numbers of ships occupy the sheltered station which this northern channel affords them. Westward, the hills follow each other, forming several intermediate and partial valleys, in undulations like the waves of the sea, and bending to the south, complete the boundary of tle larger valley I have deseribed, to the sonthward of the hill on which 1 sit. One hill alone (St. Calherine's), the higlest in elevation, and about tem miles to the sonth-westward, is enveloped in a cloud, which just permits at dim and hay sight of a signal-post, a light liouse, ind an ancient chantry, on its summit."-Annals of the l'oor, by the tate kee. Leple liteltmond. 
vegetable mould a thick layer of loose nodules but slightly abraded, and in no instance worn into the state of boulders, pebbles, or gravel. The surface of the chalk covered by the flints is furrowed and waterworn, like that of the exposed chalk along the coast. From the state of the loose flints, it is evident, that although they must have been washed out of pre-existing strata, they have not been subjected to the action of the waves for any considerable period, like the materials of the existing sea-beach. For when masses of the chalk cliffs fall within reach of the billows, the exposed portions of the flints are completely rounded before the nodules are loosened and detached from the parent rock; and so soon as the flints are liberated by the wearing away of the surrounding chalk, they are quickly driven against each other and broken, and the fragments ground into pebbles, gravel, \&c.; in this manner are formed the shingle and sands that accumulate along the sea-shore.

From the state of the down-flints, it is therefore obvious that the deposits whence they were derived, must have been less consolidated than the present chalk, and have admitted of the removal of the calcareous materials, and the consequent extrication of the siliceous nodules from the rock, 
in a comparatively short space of time; and the disengaged flints, after a rery brief exposure to attrition, must have been transported beyond the reach of the wares.

From the organic composition of the chalk (ante, p. 180), it is manifest that when first deposited at the bottom of the ocean, it was a fine white detritus or mud, resembling in its nature and appearance the chalk now in progress of formation, along the coasts of the Bermuda Islands; ; some layers of which are as rich in microscopic shells as any of the cretaceous strata. The reins and beds of flint, as we have previously explained, probably originated from the periodical introduction of thermal waters highly charged with silica, into the calcareous sediment. 'The subsequent conversion of the incoherent detritus into compact limestone, may have resulted in part from pressure, but principally from the slow infiltration of erystalline carbonate of lime; a process which has so rapidly converted the mud of the Bermulas into a rock fit for bnilding, that the imbedded shells in many instances retain their natural colour and polish.

It may therefore with great probability be assumed, that at the period when the cretaceous 
strata were subjected to those elevatory movements which ultimately raised enormous mountain-masses of chalk, together with the wealden deposits on which they rest, above the level of the sea, the last formed, uppermost, and of course least coherent beds, would be the first exposed to the action of the waves; and if the elevation were gradual,* successive layers would be subjected to the same agency, until the fragments of the ancient ocean-bed, now the Downs, were lifted above the reach of further destruction. The drainings of the elevated portions of the soft calcareous rock would then commence, and give rise to streams and rills, by which the surface would be worn into furrows and channels. Funnel-like cavities, and deep and narrow eylindrical and tubular hollows, would be formed by the gyratory action of eddies or whirlpools, induced by opposing currents; such effects may be observed on the muddy dunes of an estuary during the reeession of the tide. The beds of loose and but slightly water-worn flints - the undulated and unbroken contour of the gently swelling hillsand the smooth basin-shaped coombes, and valleys of chalk districts-characters which are strikingly

* See Mr. Lyell on the elevation and denulation of the wealden districts; "Elemen/s of Geology," vol. ii. 
exemplified in the hills before ns, would be the natural result of such operations.

From Fresinater-Gate to Compton Bay. -The road to Compton Bay sweeps round the southern slope of Afton Down; the pedestrian should take the path along the edge of the cliff to Compton Chine, where a narrow track leads to the sea-shore. As we approach this spot a fine view is obtained of the line of coast from the bay to beyond Brook Point, as is shown in the slight sketch, Pl. XI. 'The foreground is part of the southern slope of Afton Down, consisting of flinty chalk; and the foot-track to the Chine is seen erossing it on the right. The cliffs in this view are composed of the clays, shales, and sands of the Wealden, which continue to near Atherfield Point. The nearest headland is Brook Point, the western boundary of Brook Bay; and the one immediately beyond is the eastern limit of the same. The ledges of rock extending from the foot of Brook Point into the sea, are chicfly composed of petrified trees. The most distant cape is part of the greensand clifls, near Blackgang Chine; and the lofty range on the horizon is St. Catherine's llill.

Compton Chine is a decp chasm worn in the ferruginous sands by a stream that falls from 


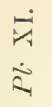



the summit of the cliff; it is situated to the west of the Blockade-station.

The footpath to the shore slopes along the face of the crumbling cliffs of greensand strata, which rise from beneath the upper divisions of the cretaceous system, as is shown in lign. 16. The succession of the beds from Freshwater to Compton Bay, i.e. from west to east, is as follows:-

1. Upper or flinty chalk.

2. Lower chalk.

3. Firestone, comprising the chalk marl.

4. Galt.

5. Greensand, consisting of bets of ferruginous sands, clays, sandstones, and layers of very compact ironstone grit.

6. Wealden clays, sands, shales, and limestones.

Geological sections of the southern coAst. - The strata incline to the west, as is shown in lign. 16, to beyond Brook Chine, where the eastern side of the anticlinal axis begins, and the dip is to the east, as represented in the continuation of the coast, in lign. $1 \%$.

This line of cliffs is, in fact, the counterpart of that of Sandown Bay (ante, p. 134, lign. 9); but the wealden deposits are here more developed, and extend between six and seven miles along the shore. As these chiffs consist of clays, sandy marls, shales, and other materials that offer 
but feeble resistance to the action of the waves, the destruction effected by the sea during the winter and early spring, when the highest tides prevail, is very great; and the wealden fossils washed out of the cliffs and strewn along these shores are so numerous, that the strand between Compton Bay and Atherfield has yielded a greater number of fossil bones of colossal reptiles than any other part of the Island. In short, these strata and their organic remains impart to this portion of the southern shore so much interest, that it is desirable to postpone a particular account of the wealden deposits for a special excursion to Brook Bay. We will therefore continne our survey of the greensand by proceeding from Compton to Atherfield, and along the Undercliff to Sandown Bay, where our investigation of the sonth coast commenced.**

The chalk, firestone, and galt of Compton Bay, are not very prolific in fossil remains; but the greensand yields ammonites, trigonia, perne', \&c.; and numerous specimens of the large oyster-like gryphea simuata, (Pl. V. fig. 3,) are generally scattered on the sands and shingle at the foot of the eliffs. At the point where the

* The visitor who would find it more convenient to continue his observations along the cliff to 13 rook Chine, should refer to chapter ix. 


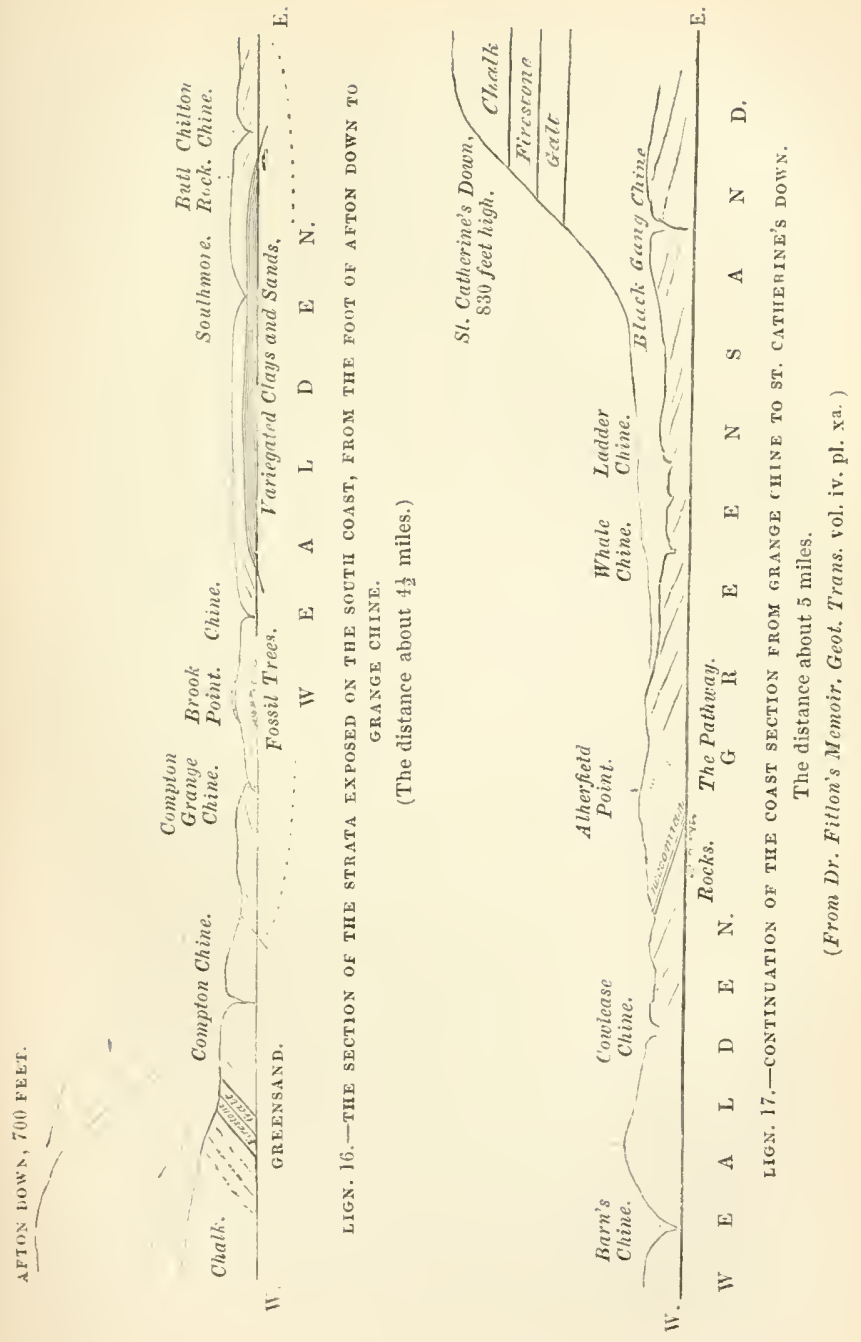


lowermost bed of the greensand is in contact with the wealden clays, the distinctive characters of the marine and freshwater deposits may sometimes be observed in a mass of the stratum but a few inches thick; marine shells appearing imbedded in the upper layers, and freshwater shells in the lower portion.

Pebbles and sinngle.-Before we ascend the cliff to pursue our excursion towards Atherfield, I would offer a few remarks on the sea-beach.

The beds of shingle along this coast, consist in a great measure of chalk flints that have been broken and rounded by attrition into boulders, pebbles, and gravel. This is evident from the peculiar aspect and fracture of the stones, and the nature of their organic remains, of which some traces are generally manifest. 'The clear transparent pebbles, with bands and reins of quartz and chalcedony, which in some specimens are as clear as crystal, and in others of a bright yellow, amber, dark brown, and bluish-black colour, have a similar origin. The moss-agates, * as they are called by the lapidaries, are silicified chalk sponges; and the beautiful fossils (Choanites) + commonly known as "petrified sea-anemones," are

- Not the German moss-agates exhibited in the shops as the genuine productions of the Island. See note to page 18.

+ "Thoughts on a Pebble," pl. 1 and 2. 
characteristic zoophytes of the white chalk. Small pebbles of pure transparent quartz or rock-crystal, are often found in the shingle in Compton and Sandown; these have probably been washed out of the wealden strata, for pebbles identical in mineralogical character occur in the grits of Tilgate Forest and Tumbridge Wells.

But the shingle contains other siliceous pebbles which essentially differ from those of the chalkflints. Some of these are composed of a clark brown mottled jasper, and when cut and polished resemble the well-known Egyptian pebbles; others are of an opaque white jasper, veined with black dendritical or arborescent figures, or marked with zones of rich brown tints. Some have a concentric arrangement of bands of silex of various shades of colour, and resemble agates; others assume the character of botroidal and mammillated chalcedony.

The differences observable in the materials composing the shingle, did not escape the notice of Mr. Webster, who describes some of the principal varieties of the pebbles, and suggests that those which are not waterworn chalk-flints, may have been derived from veins or nodular masses of silex, in tertiary strata now destroyed. A polished slice of silicified wood found in the shingle of 
Sandown Bay, was presented to me by Mr. Fowlstone, of Ryde. I believe specimens of this kind are very rare in the Island; but on the western coast of Sussex, waterworn fragments of silicified monocotyledonous wood are occasionally met with.

Boulders and pebbles of petrified bone and wood, and of shelly limestone, are common on the beach in Compton and Sandown Bays; they are from the wealden beds, and will be more particularly noticed in a subsequent chapter. 


\section{CHAPTER VIII.}

FROM COMPTON BAY TO ATHERFIELD POINT-ATHERFIELD CLIFFSGREENSAND SERIES-NEOCOMIAN OR ATHERFIELD STRATA-GREENSAND FUSSILS - CLIFFS AT BLACKGANG CHINE - THE UNDERCLIFF -GFOLOGICAL STRUCTURE OF THE UNDERCLIFF - FOSSILS OF THE FIRESTONE-SOUTHERN RANGE OF CHALK DOWNS-COAST OF THE UNDERCLIFF-EROM VENTNOR TO SANDOWN BAY.

From Compton Bay to Atherfield Point.The road from Compton Chine to the coast-guard station at Atherfield Point, runs along the southern flank of Shalcomb and Mottestone Downs. As we pass Brook Manor-house the ferruginous beds of greensand may be traced in the banks on the road-side; and Brook church is seen standing high up the hill on a terrace of those deposits. The relative positions of the strata in this district are displayed in the cuttings on the sides of the road from Shalcomb Down through the village of Brook to the sea-shore; as shown in lign. 18. If we proceed from the coast at Brook Chine through the village, and ascend the road by the church, and over Shalcomb Down, we pass in succession, 1, the Wealden; 2, the Greensand; 3, the 
220 GEOLOGY OF TIIE ISLE OF WIGHT.

Galt; 4; the Firestone; and then cross the ridge formed by the highly inclined strata of the Whitechalk.

Shalcomb Down.

XN. Fossil Trees. W E A I D E N.

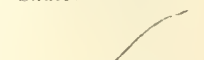

Brook Point. Chalk.

LIGN. 18.-SECTION FROM BROOK-POINT TO SHALCOMB-DOWN; 14 MILE.

The turnpike-road leads through the villages of Mottestone* and Brixton, to Shorwell, where it divides, and sends off a branch to Newport on the north-east, and another on the south-east, through Kingston and Chale to Blackgang Chine. About midway between Brixton and Shorwell a tenantry road turns off to the right, and admits a carriage to within a few hmdred yards of the cliff, near the Atherfield Coast-guard Station. This is the most convenient place to alight, and reach the sea-shore near the junction of the Greensand and Wealden formations. The path down the precipitous face of the cliff lies a little to the east of the

- On an eminence overlooking the village of Mottestone is a rude pillar of ferruginous sandstone called the "Long-Stone," and which was probably erected as a landmark or houndary stone, at a very remote period. It is twelve feet ligh and of an irregular quadrangular form. 
Station; it is a mere foot-track worn in the rock by the sailors and fishermen.* At a moderate distance westward of the spot where the path reaches the shore, is the headland called Atherfield Point, on which stands the Station-house; and at its foot, a ledge of rocks extends into the sea. Near this place after recent slips of the cliff, and the removal of the fallen debris by the waves, the uppermost of the Wealden deposits, and the lowermost of the Greensand may be seen in juxta-position; in other words, the line of demarcation between the accumulated sediments of a mighty river-some primeval Nile or Ganges, teeming with the spoils of the land and the exuviæ of extinct terrestrial and fluviatile animals and plants - and the bed of a vast ocean, loaded with the debris of marine organisms, of genera and species unknown in the present seas.

Atherfield Cliffs.-These cliffs are about 150 feet high, and, with the exception of a few feet of Wealden clay forming the base of the headland above mentioned, entirely consist of the greensand strata, which extend eastward as far as the

* This path is too precipitous and inconvenient to be attempted without risk by ladies or invalids. I have always visited the spot by this route, and am not aware of there being a more casy descent to the beach, except at a long distance from the most iuteresting part of the clifts. 
eye can reach. The total thickness of the series is upwards of 800 feet; but the section exposed, though vertical, is in an oblique direction to the planes of stratification, and from the slight angle at which the strata dip to the north-east, the cliffs as far as Blackgang Chine are composed of the greensand deposits. To the eastward these strata are concealed by the upper cretaceous group along the Undercliff, reappear at Bonchurch Cove, and continue to Sandown, extending as far as the anticlinal axis of the Wealden in the bay.

The lowermost bed which rests on the Wealden at the base of Atherfield Point, is but a few feet above the beach; the uppermost strata first appear on the shore to the east of Rocken-end; between these two points the cliffs are made up of sands and argillaceous deposits of various colours, composition, and thickness, containing particular collocations of organic remains. The importance of the Atherfield section as elucidating the nature and relations of the lower group of the cretaceous system, was but little regarded till the appearance of Dr. Fitton's memoir "On the Strata between the Chalk and Oolite." * Since that time this locality has acquired additional interest from its affording 
a solution of the geologieal problem, to which we shall hereafter briefiy advert. The subsequent memoirs by the same author, * Captain Ibbetson, Professor Edward Forbes, $\uparrow$ and Mr. Simms, $+\underset{+}{\dagger}$ eontain an claborate account of these deposits, and of the nature and distribution of the fossils they contain. The limits necessarily assigned to the present volume, will only admit of a concise notice of the facts detailed in those publications, and a general view of the geological phenomena presented to observation in a stroll aloug the shore, from Atherfield Point to Blackgang Chine.

Greensand series.-There are 63 distinet beds between the Wealden at A therfield Point, and the upper stratum of Greensand which is in contact with the Galt near Blackgang Chine; the total thickness being 843 feet.\$ These deposits have been variously grouped and named by different observers; but the most practieally useful arrangement to the investigator on the spot, is that which especially relates to the organie remains.\| We will now briefly notice the principal subdivisions in an aseending order; that is, from the Wealden at Atherfield Point,

* Geol. Journal, vol. i. p. 179.

+1 1bill. p. 190.

$\mp$ Ibid. p. 76 .

$\S$ Captain Ibbetson.

II A list of the strata, and a table of the distribution of the fossils, are given in "Geol. Journal," vol. i. p. 195. 
to the junction of the greensand with the galt (lign. 17.).

The Wealden clay, as previously stated, first appears in a bed five or six fect thick, at the foot of Atherfield Point; the upper layers are shaly, and contain freshwater shells (cyclas, paludina, potamides, $*$ Pl. VI.) similar to those we observed at Sandown Bay. $\downarrow$ The Wealden clay in the upper part is intermixed with grey and green sand; and two or three inches above there is a stratum of sandy clay containing marine shells. The distance between the layers of fluviatile and marine shells is therefore but a few inches; so that, as Dr. Fitton reniarks, portable masses containing characteristic shells of both formations may be extracted. I lrave not been so fortunate as to visit Atherfield Point when the line of junction at the base of the cliff, and to the westward, was exposed to any considerable extent. But sometimes, from a conjunction of favourable circumstances, the strata are laid bare for several hundred yards. 'This happens

* Polamides are spiral fresh-water shells, which much resemble in form those helonging to a marine genus termed Cerithium; the Cerithia mentioned by Dr. Fitton as occurring in the Weald elay at Athertield, may possibly be P'otamides. I have never observed any vestiges of Cerithia in the Wealten dejosits.

t $\Lambda$ few small thin-slielled oysters were observed by Dr. Fitton in this bed. "These fossils occur within a very few inclues from the junction with the sand above the Wcalden."-l'rucecdenys, Geol. Suc. 
after heavy gales and high tides, which sweep away both the fallen masses of rock and the seabeach, and expose a large surface of the adjacent strata washed clean, and visible at low water.*

1. Lowest Greensand clay. $+-\mathrm{A}$ bed of brown clay with marine shells : 3 feet thick. In the lowermost layers, near the Wealden shale and clay, are seams of minute fishbones.

2. Perna Mulleti band.-A stratum two feet thick, of a very firm sand-rock, characterised by numerous shells, and especially by a layer of the Perna Mulleti ( Pl. IV. fig. 6); which also occurs in the same relative stratigraphical position in Compton and Sandown Bays.

3. Lower Lobster clay-bed.-Clay strata, with numerous fossils in the lower, and but few in the middle beds. The upper lajers are remarkable for the abundance of a small species of lobster (Astacus), which occurs in a beautiful state of perfection, imbedded in blue saponaceous clay approaching to fuller's earth. The specimen figured in the Vignette of the title-page of this work, is from this stratum. Total thickness 100 feet.

4. The Cracker's rock. - Sandy clay with two bands of nodular or concretionary masses of very hard calciferous sandstone : 18 feet. These beds are highly interesting for the abundance and variety of their organic remains. The nodules consist of very compact rock, and contain innu' merable shells in a perfect state, of which many species

* Such was the state of the cliff when visited by Dr. Fitton in 1843. Pruc. Geol. Suc. vol, iv, part 1.

† The names adopted are those employed by Captain Ibbetson and Professor E. Forbes. Geol. Journal, vol. i. p. 190.

$\ddagger$ This local name is said to be derived from the nuise made by the breakers when dashing over the rocks and ledges of this concretionary sand-rock. 
do not oecur in any other strata. The Gerrillia anceps ( Pl. IV. fig. 3) is erowded together in groups of hundreds, and the shells are as perfect as if lying in their native bed. Sereral small shells from the C'racker's rock are figured in $P l$. V. (figs 4, 6, 7, 8, 9, 10). These fossils oceur in such numbers and variety, that almost every considerable fragment of the rock will be found to contain sereral species.

5. Upper Lobster clay.-A deposit of saponaceous clay, similar to No. 3 ; and abounding in the same kind of fossil lobsters as that bed. It also contains ammonites and other shells : total thickness 20 feet.

6. Zone of Terebratulre-Clays full of fossils, 20 feet: above which is a bed of dark sand, 22 feet in thickness, enclosing immeuse numbers of Terebratula ( $\mathrm{Pl} . \mathrm{V}$. fig. 5), and Serpulex.

7. Zones of Gryphece and Scaphites.-A series of sands and clays, including layers of Gryphece (the large bivalre figured in $P l$. T. fig. 3), imbedded in dark sand, and alternating with bands of nodules whieh contain gigantic Scaphites ( $P l$. V. fig. 11), ammonites, and numerous other fossils : total thickness 155 feet.

S. Upper zone of Terebratula. $-\Lambda$ bed of sand 30 feet thiek, full of layers of Terebratula (chiefly of Terebratule biplicata): above which is a stratum of dark sand, 24 feet thick, with a band of Gryplea as in No. 7 , but without the Scaphite nodules.

9. Ferruginous sands. - Sands highly ferruginous, with layers of dark blue elay, and bands of ironstone nodules full of casts of shells ( $P l$. IV. fig. $7, P l$. V. fig. 1), of the genera Tenus, Thetis, Trigonia, \&c. Seams of lignite are disseminated through the lower beds in undulated laminæ; and thin layers of ironstone grit without fossils, oceur in the upper part of the series. The beds in eontact with the Galt are generally of this character. 
In the upper 250 feet of the greensand but f'ew organic remains are met with, and the strata are more or less highly charged with peroxide of iron. "Every thing," says Professor E. Forbes, "in this stage, appears to indicate a shallow and barren sea, probably from an elevation of the sea-bottom, previous to a new state of things, when a fresh series of clays, forming the Gult, being deposited, the majority of the animal forms which characterise the clays of the greensand disappear, and are replaced by distinct species, representative in time." *

Neocomian or Atherfield strata.-The inferior portion of greensand at Atherfield, from the lowest bed to the Crackers inclusive, abounds in fossils which are either very rare, or altogether absent in the upper part of the series. A group of subcretaceous deposits near Neufchatel, in Switzerland, having lately been found to contain many species of shells not previously known in other parts of the cretaceous system, has, in consequence, been described by some eminent French geologists as a distinct formation, belonging to a period antecedent to the deposition of the Greensand, and synchronic with the Wealden; and they have designated the

* Geol. Journal, 1845. 
group "Terrain Neocomien." But Dr. Fitton has shown, by a careful comparison of a large number of the French fossils with those from Atherfield, that so close an agreement exists in the organic remains, as to leave no reasonable doubt that the so-called Neocomian strata are but the equivalents of the lower series of the English greensand system.*

In a Report read before the British Association of Science, at Southampton, $\uparrow$ Dr. Fitton gave a table of 150 species of shells, the stratigraphical position of which has been accurately determined. From this it appears that 130 species occur in the lowermost 150 feet of strata; and that in the upper beds, comprising a thickness of nearly 700 feet, but twenty additional species are met with; the absolute number of fossils also rapidly diminishes, but few, if any, organic remains appearing in the uppermost layers. But throughout this period of consecutive deposition, one series of fossils only is indicated, bounded by the Wealden below and the Galt above. It is the lowermost part of the Atherfield section which is regarded as the equivalent of the remarkable

* The name Neocomian is introduced in the section, lign. 17, p. 215, to elucidate these remarks.

t In September, : 816. 
fossiliferous group of Neufchatel. The principal difference between the continental and English greensand fauna, is stated by Professor E. Forbes to consist in the abundance of gasteropoda and cephalopoda in the former, and of acephalous bivalves in the latter.

Greensand fossils.*-The organic remains of the greensand to be met with along this coast are almost exclusively shells; but few traces of the higher orders of animals, or of plants, have hitherto been observed. It should, however, be borne in mind, that remains of land reptiles, and trees, and plants, have been found in strata of this formation in Kent; similar relics may therefore occur in the same deposits in the Isle of Wight. $\uparrow$

Of the vegetable kingdom but few vestiges have been discovered. The laminæ of lignite in the upper ferruginous beds, and obscure traces of fuci in some of the lower sandstones, are the only indications of the flora of this geological epoch that have come under my notice. But remains of the

* The finest collection of the organic remains of the greensand of the 1sle of Wight is, I believe, that made by Captain Ibbetson, and now exhibited in the Polytechnic Jnstitution of London. The Geological Society has the most complete series of the shells, principally contributed by Dr. Fitton, and named by Professor Forbes. Figures of most of the species will be found in " Mineral Conchology," Dr. Fitton's "Memoir," and in the "Geological Journal," vol.i.

+ See "Wonders of Geology," vol, i. p. 394. 
foliage of a fern that abounds in the Wealden (Lonchopteris Hantelli, lim.91), were discovered by Mr. Morris in many of the strata at Atherfield; and the Messis. Gladstone have since found several leaflets of the same species associated with trigoniar, \&c. in ironstone nodules at the foot of Shanklin Cliff. 'This interesting fact we shall have occasion to notice in a subsequent chapter. Of the porifere and corals but few species occur. Traces of bulbiform Siplenia, (apparently $S$. pyriformis, Di. Fitton's Memoir, Pl. XV.), are sometimes displayed on the waterworn surface of fallen blocks of sandstone. A small elegant coral, a species of Astrea, is not uncommon in the Cracker's Rock at Atherfield.

The lowermost beds at $\Lambda$ therfield Point being very fossiliferous, the collector will have but little trouble in obtaining good specinens of the shells distributed in those strata: the pernu mulleti (Pl.IV. fig. (i) may generally be extracted tolerably perfect.* From the nodular masses of the Crackers with which the shore at low water is often thickly strewn, an abundance and varicty of shells may be procured; and that part of the

- It is necessary that the geologist should so arrange the time of his visit to this coast, as to arrive at Atherfield at the beginning of the chb of the tide, that he may be atle to examine the clifts and collect specimens at leisure. 
clifl, where the two parallel layers of these concretionary masses are within reach, (ahmost half a mile to the east of Atherfield Point), will afford specimens at all times. The large aryphea sinuatu $(P l . V$. fig. 3), may be found everywhere along the shore; the shell being sufficiently strong to resist for a time the action of the waves, clean and perfect examples often occur imbedded in the sand. Beneath Walpen High-cliff, and at Whale's Chine, the gryphea bed may be examined in situ; the terebratula sella (Pl.V. fig. 5), may be obtained from the loose green sand (No.6, p. 226), in great perfection and variety.

The magnificent cephalopodous shell, the $S c a-$ phites grandis, * (S. gigas of our Pl. V. fig. 11), is most likely to be met with near the base of the same part of the cliffs. Some fine specimens have been found along the shore near Ladder Chine; and very large ammonites and nautili occur in the same locality. On the shore, not far from the base of Blackgang Chine, nodules with scaphites

* This shell has been described under different names, as Crioceras Bowerbanksii, scaphites gigas, \&c.; the latter name is given in the description of $P l$. V., but Professor E. Forbes has adopted that originally affixed to this gigantic cephalopod by Mr. Sowerby. Scaphites are distinguished from Ammonites by the disunion of the whorls, and from IIamites, by the spiral arrangenent of the posterior volutions. A very small species of Scaphite (not exceeding an inch in length) is frequent in the chalk marl. See "Medals of Creation," vol. ii. for an account of fossil Cephalopoda. 
may be observed abore a bed of sand full of terebratulæ.

'The fossil lobsters, the most beautiful of the Atherfield fossils, may generally be met with after recent slips of the cliff involving masses of the strata (Nos. 3 and 5, pp. 225, 226,) in which they occur. The vignette of this volume (engraved by Mir. Lee from a drawing by $M r$. J. Dinkel) represents an exquisite specimen from a fallen block lying near the pathway at the foot of Atherfield Cliff.

Minute bones of fishes in the lowermost clay, and a few teeth of the Shark family, are the only remains of vertebrate animals I have observed; but Capt. Ibbetson has obtained from these cliffs a specimen of extraordinary interest. It is a considerable portion of the skull, with the bones of the face and the jaws and teeth attached, of a species of Hybodus; a genus of fishes of the shark tribe, having teeth of a transversely elongated form, with a series of compressed conical cusps, of which the middle one is the longest.*

In this remarkable fossil the mouth is open, and forms a semilunar aperture six inches wide. The upper jaw has twenty-four teeth, and the lower nineteen, in their natural position; two rows of

- Medals of Creation, vol, ii, p. 622 . 
successional teeth are traceable behind the anterior series. 'These teeth, as shown in lign. 19, have a central cusp rather hooked, and two lesser points on each side.

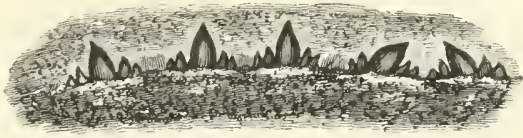

LIGN. 19.-FIVE TEETH ATTACHED TO A PORTION OF THE JAW OF A PISH OF THE SHARK FAMILY ; FROM ATHERPIELD.

(Hybodus bassanus, of Sir P. Egerton. Geol. Journal, vol. i. pl. iv.)

The Hybodonts, like other fishes of this family, were armed with strong dorsal spines, which are often found in the lias, oolite, and wealden strata; and rarely, in the chalk.*

The Cliffs at Blackgang Chine.-Proceeding from Atherfield Cliffs eastward, the first interesting point is Blackgang Chine; a spot well known to every tourist who visits the Undercliff. Viewed from the sea-shore at low water, especially when the springs which feed the waterfall have been swollen by heavy rains, the effect is highly

- Capt. Ibbetson's specimen is in the Polytechnic Institution on a pedestal at the entrance of the Isle of Wight model-room. It is figured and described by Sir Philip Egerton in "Geol. Journal," vol. i. p. 197. Unfortunately, the drawing was made before the bones of the face and jaws were cleared of the adherent stone, and it therefore represents only the margin of the jaws with the teeth, surrounded by a shapeless mass. 


\section{GEOLOGY OF TIIE ISLE OF WHGH'T.}

pieturesque. The cascade falls in a perpendicular colnmm from a ledge 70 feet high, down the midst of a deep chasm formed in dark ferruginous clays and sands, and surmounted by broken cliffs 400 feet high; and towering above all is the majestic escarpment of Saint Catherine's-hill, rising to an altitude of between eight and nine hundred feet. The sketch in $P l$. XII. shows the section exhibited in the face of the cliffs. The bands of greenish-grey sand and sandstome which alternate with fermginous clays in this division of the greensand system, appear very prominent, owing to the wearing away of the soft and friable intermediate beds.

As the face of the sandstone, after long exposure to the atmosphere, separates into square blocks, the appearance of the projecting bands of stone, which are from ten to fifteen feet thick, is very singular, and is not maptly compared by Sir H. Englefield to courses of masonry built up at different heights to sustain the mouldering cliffs. The thin layer of ironstone grit which, as we have previonsly remarked, is very constantly found in this division of the greensand, constituting as it were a line of demarcation between the upper arenaceous deposits and the lower more argillaceous group, intereepts the water that percolates 
$\overrightarrow{\tilde{R}^{\prime}}$

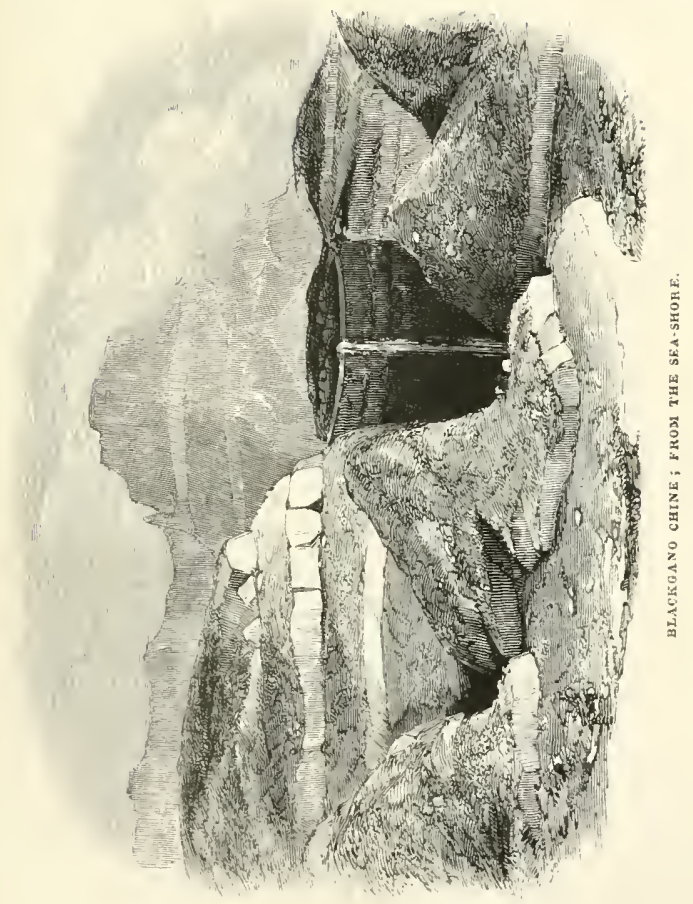



through the upper porous strata, and projecting in a ledge forms the bed of the stream that falls in a cascade orer the face of the cliff.

In reference to the springs along this coast it may here be remarked, that no less than ten copious streams issue from the strata on the south side of the range of hills facing the Undercliff, and run directly into the sea; most of those which flow from the greensand are chalybeate. At Sandrock, near Blackgang, is a celebrated aluminous chalybeate spring, of which an analysis was published by Dr. Marcet in Geol. Trans. vol. i. This water is lighly charged with sulphate of iron and alumina; it rises from a bed of sand within fifty feet of the galt.

The Undercliff.-We have now arrived at the western extremity of that interesting and picturesque region known as the Undercliff of the Isle of Wight; and which may be described geologically, as a miscellaneous accumulation of debris, principally composed of fallen masses of the upper cretaceous strata, occasioned by the encroachments of the sea on the lower argillaceous and sandy deposits that form the base of this line of coast. The Undercliff consists of an irregular terrace, sloping towards the south, from a quarter to half a mile in breadth, and six miles in length; its elevation 
above the sea is from 100 to 400 feet. It is protected on the north by the escarpment of the southern ehain of hills, which forms a line of vertical cliffs, from 200 to 400 feet high, and extends from St. Catherine's to Shanklin Down.

There is perhaps no tract of such limited extent, that affords so remarkable an instance of the modification of climate induced by geological structure and physical configuration, as the Undercliff. Completely sheltered on the north by the range of chalk cliffs-clevated above the influence of the mists and fogs of the sea-shorepossessing a soil composed of the detritus of chalk and sandstone, which rapidly absorbs and carries off superfluous moisture, yet supports a lnxuriant vegetation - with an undulated and varied surface enjoying throughout its whole extent a southern aspect-and fanned only by breezes which invigorate but do not chill-this fairy region well merits the high encomium of the medical philosopher. It is indeed, what Sir James Clark, in his invaluable work on Climate, has described it to be-" a lofty natural terrace backed by a mountainous wall on the north, and open on the south to the full influence of the sun from his rising to his going down, during that season when his influence is 
most wanted in a northern country. The climate is remarkably equable as well as mild and dry, and there are not many days during the winter on which the invalid cannot take some exercise in the open air. The mildness and dryness of the climate during the winter months, may be in some degree estimated by the circumstance of myrtles, geraniums, and various tender greenhouse plants usually withstanding the winter in the open flower borders. The absorption of heat by the almost perpendicular cliffs of the Undercliff, exposed as they are to the rays of the sun during the whole day, must be considerable, even in winter; and the radiation of this heat during the night no doubt tends to equalize the temperature. To the invalid who has a taste for natural history, this sheltered district and neighbourhood possesses an additional advantage. It is rich in varied and interesting plants; indeed the specimens of natural history with which it abounds offer abundant inducements to exercise, and healthful mental occupation, to the cultivators of this delightful science." * How great will be my reward, should these humble pages open a new source of intellectual enjoyment, to any of those who may repair

"The Sanalive Infuence of Climate; by sir James Clark, Bart. M.D. Sc. Fourth edition. London, 1846. 
to this favoured spot, for the restoration of health, or the alleviation of mental affliction.

Geological structure of the Underchiff.The structure of this district will be readily understood by an examination of the western extremity of the Underchiff. The diagram, lign. 1\%, (p. 215), illustrates the position of the several groups of the cretaceous beds at St. Catherine's Down, which is 830 feet in height; the strata are nearly horizontal. The greensand series reaches to the top of the cliff at Blackgang, upwards of 400 feet high ; the galt lies above it, and forms a bed more than 100 feet thick. The marls, sands, and calcareous sandstones, comprised under the name of firestone, in thickness about 100 feet, next appear, and rise into a vertical inland cliff, half a mile from the shore. Strata of white chalk form the summit of St. Catherine's Down, the total thickness amounting, in some places, to 250 feet; but on the south-western brow of the hill these beds thin out, and form a mere capping over the firestone.*

The Galt is seen at the top of the ravine west of Blackgang hotel, resting upon the greensand which

* Mr. Lowry, the eminent engraver, informs me that the firestone reaches to within 133 feet of the beacon on St. Catherine's Down, as he ascertained by baronetrical observation in 1837 . 
extends in a terrace beyond it: some of the fossils peculiar to this deposit (Inoceramus sulcatus, and I. concentricus) have been obtained from this place. This bed also appears beneath the firestone on the face of the cliff east of the Sandrock spring, above the road leading to Ventnor.

The Firestone in the southern face of St. Catherine's hill, above the road from Niton, presents the usual characters of this group as they appear in a succession of terraces along the Undercliff.* The chalk-marl forms the upper part of the series, and passes downwards into greenish grey sands and calcareous strata, in which are layers of bluish marl rock. Strata of cherty sandstone, alternating with layers of sandy marl, occur in the lower part; and from the disintegration and removal of the intermediate earthy beds, the chert appears in projecting ledges along the face of the southern escarpment of the downs, through a considerable extent of the Undercliff. This circumstance imparts a peculiar feature to the landscape, and, under certain combinations of rock and vegetation,

* The firestone strata in the Isle of Wight are nore numerous and diversified than in Kent and the south-east of sussex, and resemble the equivalent deposits in the western distriet of Sussex and Hampshire, so ably elucidated by Sir Roderiek Murchison, in his first contribution to that department of natural philosophy, the boundiries of which his genius and important researches have since solargely contributed to extend. (See Geol. Trans. vol. ii. Second series. 1826.) 
contributes greatly to the picturesque character of the local scencry.*

The layers and concretionary masses of chert are principally distributed in the upper part of the series; and beneath them are sands, and a bed of sandstone from two to four feet thick, which, though soft when first extracted, hardens by exposure to the air, and becomes an excellent building material. The ancient churches on the south side of the Island have been constructed of this stone, and it is being largely quarried for the edifices now in progress of erection.

Fossils of the Firestone strata.-The fossils of the arenaccous and cherty strata of the firestone group, comprise many species which also occur in the uppermost deposit, the chalk marl; and likewise several that have either not been observed, or are very rare in the other strata. They consist of several kinds of Ammonites, Nautili, Hamites, Scaphites, and other cephalopoda; numerous bivalves, especially pectens, terebratula, trigonia,

* Captain Ibletson, whose beautiful and accurate models of the Undereliff are exhibited in the Polytechnic nstitution, subdivides the firestone group into the following:-1. Upper greensand; 2. Chloritic marl; 3. Secoud bed of gremsand; 4. Fossiliferous marl, in which large scaphites ocenr; 5. Two alternations of malm and $\mathrm{rag}$ : the term malm is applied to a firm argillaceous rock, and rag, to the cherty sandstone that alternates with the former. $A$ very large collection, comprising numerous species of shells, zooplytes, \&c., lias been obtained from these strata, and especially from the fossiliferous marl. 
\&c., and of a few genera of simple univalves, as Cirrus, Trochus, Avellana, \&c. The bare enumeration of the species would occupy a considerable space, and be umintelligible, except to the scientific reader, without the aid of figures.

There is, however, one fossil which it is necessary to describe, from the abundance of its remains which meet the eye in ahmost every block of firestone. It is a species of Siphonia (S.'Websteri), a zoophyte resembling the sponge in its porous structure, but possessing numerous tubular chamnels that permeate the general mass, and communicate by openings into a central cavity.* This species is in the form of an oblong bulb with a shallow opening, supported upon a long slender stem,

* Mr.Webster on some new varieties of fossil Alcyonia, Geol. Trans. vol. ii. First series, p. 376. Mr. Webster mentions that the first specimens showing the connexion of the stems and bulbous part, were observed on some "stupendous and difficultly-accessible masses of rock lying under the romantic cliffs of Western-lines." The branches vary in size from half an inch to three inches in diameter, and from six to eighteen inches in length; they terminate above in a bulb or head, somewhat resembling in form a closed tulip, and from one to six inches long; the other extremity branches into root-like fibres, by which these bodies, when living, were attached to rocks or stones. If the stems and bulbs are broken transversely, they are found to consist of bundles of longitudinal tubes; and this internal structure is generally silicified, so that polished sections are very interesting. I need scarcely remind the reader that these bodies have no relation to the Alcyonia, which are polypiferous zoopliytes; whereas these fossils are simply a congeries of tubes and pores, like certain sponges. The fossil that is figured in my "Mledals of Creation" (vol.i. p. 259), as Siphonia Websteri, is not that species, but $S$. pyriformis of Goldfuss, which generally occurs in the green sand, but is occasionally met with in the firestone, and in the grey chalk, associated with another common fossil sponge, the Scyphia meandrina. 
having a root-like base by which the original was attached to the roek. This fossil was first figured and described by $\mathrm{Mr}$. Webster, under the name of tulip alcyonium. The bulbs and stems are often disposed in relief on blocks that have been weathered, or washed by the sea; for the fossils, being harder than the surrounding stone, more effectually resist abrasion, and large surfaces of firestone are therefore covered with their remains, which, being whiter than the rock, are very conspicnous.

Fossil Cycadeous plant.-But the fossiliferous marl (as Captain Ibbetson designates the bed most prolific in organic remains) has lately been found to contain relics of a higher order than any previously known to occur in the cretaceons strata of the Isle of Wight. In the collection deposited in the Polytechnic Institution, there is a specimen from the marl near Ventnor, that several years ago attracted my attention, but which I was mable to obtain an opportmnity of examining till a few weeks since, when Captain Ibbetson, with great liberality, permitted me to inspect and figure it for this work. It proved to be, as I had conjectured, the summit of a stem, surromnded by the petioles, or leaf stalks, the leaves themselves having either been shed or decayed, of the Clathraria Lyellii, a 
cycadeous plant, hitherto only known in the Wealden formation. A figure (lign. 93) and description of this most interesting relic, will be given in the account of the organic remains of the Wealden in Chap. X.

Fossil femur of a reptile. (?)-Another discovery, not less important, has recently been made in the eastermmost quarry, above Bonchurch, and was communicated to me by S. M. Saxby, Esq. of Bellevue House, Ventnor; a gentleman to whom I am indebted for many interesting local details relating to the strata and fossils of the Undercliff. The specimen referred to is either the humerus (arm-bone) or femur (thigh-bone) of a terrestrial animal, probably of a gigantic lizard. It is broken transversely, and some two or three inches of the middle portion of the shaft are missing, but the articulating extremities are in excellent preservation. So far as a hasty inspection would enable me to form a conjecture of the affinity of this bone to recent types, it appears to approach nearest to the femur of the Monitor or Iguana; most certainly it bears no resemblance to the corresponding bone of any of the Wealden reptiles that have come under my notice. The lower portion is 9 inches in length, and terminates at its distal extremity in two large 
laterally compressed condyles, having a very wide popliteal space between them; the anterior or patellar aspect is smooth, and but little depressed. The transverse diameter of the bone at the condyles is $6 \frac{1}{2}$ inches; the upper and fractured end of the shaft is $3 \frac{1}{4}$ inches in diameter in the same direction. The proximal extremity, or head of the bone, is somewhat compressed, and its characters are concealed by adherent firestone; it is 7 inches wide in the transverse and longest diameter. This portion of the bone is one foot in length; the transverse diameter of the inferior and fractured end is 4 inches; and as the corresponding part of the shaft of the distal portion is $3 \frac{1}{4}$ inches, it is obvious that the lost intervening piece of bone must have gradually diminished in circumference $2 \frac{1}{4}$ inches, from abore downwards. 'The shaft in the transverse diameter measures 4 inches; in the antero-posterior, only 3 inches. But the most remarkable character of this bone is the relatively enornous size of the medullary eavity, which is 3 inches by 2 ; the walls of the bony cylinder at the fractured part being only half an inch thick. I have not been able to procure a fragment for microscopical examination, by which its reptilian or mammalian affinity might be determined : but for the courtesy 
of Mr. Saxby, even these brief details could not have been obtained.*

Fossir fucr.-White ramose and meandering lines are not uncommon on the surface of the sandstone: these are probably vestiges of fuci or other marine plants. A well-known delicate species, the Fucoides Targionii, $\uparrow$ that abounds in the malmrock of Bignor, in Sussex, occurs sparingly at Ventnor. Some very curious trifid impressions are sometimes observable on the surface of waterworn blocks of sand-rock, and are possibly referable either to this tribe of plants, or to some kind of siphonia. Some of these imprints so closely resemble, both in form and in their arrangement on the surface of the slabs, the supposed Onithicnites, or footsteps of birds, that occur in such perplexing abundance and variety in certain ancient secondary rocks of the United States, that Mr. Saxby, who first observed these fossils, was at infinite pains to ascertain their nature. The examples hitherto obtained, though very specious in appearance, cannot, I conceive, be regarded as the imprints of the feet of any animal: imequivocal

* Mr. Saxby has kindly informed me, that the quarry at Bonchurch is precisely at the commencement of the land-slip by the turnpike road, and the layer in which the bone was found is three or four feet above the firestonc.

+ Medals of Creation, vol. i. p. 105.

‡ Ibid. vol. ii. p. SI0. 
evidence as to the origin of these problematical objects is still desirable.

Molluskite.-'The soft bodies of the testaceous mollusca often occur in a fossil state, changed into a brown carbonaceous substance, which I have proposed to distinguish by the term molluskite.* When empty shells are found enclosed in rocks, the mineral matter generally fills up the cavity and forms a cast of the interior; but if the animal oecupied the shell at the time it was imbedded, the soft parts appear to have become changed into a brown or black substance, which in some instances retains the form of the original, but in general occurs as an amorphous mass, containing a large proportion of animal carbon. In the greyish green sands of the firestone of Kent and Sussex this substance often oceurs, and it is equally abundant in some of the sandstones of the Undercliff. The brown spots dispersed through the stone forming the mouldings and mullions of the new church at Ventnor, are composed of molluskite. In recently extracted stone at Ventnor, I have observed shells of trigonia, rostellarix, and cucullea, filled with this carbonaceous matter. The shelly limestones of the Wealden, called Sussex and Purbeck marbles, are mottled with black molluskite, 
consisting of the carbonized remains of the river snails of which the limestones are composed.

Southern ravge of Chalak Downs.-From this digression on the zoological characters of the middle system of the chalk formation, we resume our geological survey of the southern coast. Before we climb St. Catherine's-hill, let the observer for a moment take another glance at the view commanded by the terrace in front of the Blackgang hotel, which affords a coup d'xil of the southwestern shores. Looking down the ravine immediately at our feet, the aspect of the scene is singularly wild and dreary, from the sombre colours and fantastic masses of the broken walls of the chine, and the gloomy shade thrown athwart the chasm by the projecting cliffs. On the coast, the greensand strata are seen stretching on to Atherfield Point; and beyond may be distinguished Brook Point, which from this elevated spot appears as a low promontory; and farther west are the chalk cliffs, gradually vanishing away towards The Needles.

Ascending St. Catherine's-hill, a magnificent panoramic view bursts upon the sight. From the summit, a height of between eight and nine hundred feet, when the atmosphere is clear, the eye commands at one glance the grand features of 
the physical geography of the Island, and the range and extent of the principal gronps of strata. We are now on the western extremity of the southern range of chalk downs which, as previously explained (ante, p. 17\%), is separated by a considerable district of greensand from the central chain of hills.* This system of chalk downs varies in breatth from half a mile to three miles, and extends six miles in a direction E.N.E. and W.S.W. from St. Catherine's-hill to Dunnose, its eastern termination, which is nearly 800 feet high. The intermediate parts of the range maintain an elevation of from 650 to $\$ 00$ feet, with the exception of a deep valley on the east of St. Catherine's, through which the road to Niton passes; and another at Steephill called the Shute or Shoot, above Ventuor, traversed by the road to Appuldurcombe and Newport. A marl bank on the side of the shute abounds in fossils. $\downarrow$

The strata of these hills are nearly horizontal, Javing only a slight inclination to the south-east. From Ventuor to St. Boniface Down, above Bonchurch, + a distance of three quarters of a mile, the

- liefer to the diagram. $P l$. VIl. aud the map, Pl. XX.

+ Mr. Saxby informs me that he las obtained from this locality turrities, ammoniles, nutuli, belewnites, and many other marl fossils.

1 thigh up on the slope of the hill bursts forth a spring called St. Bomifnce'surll, to which local legends have attached much veneration. 
usual smooth verdant character of the chalk is resumed, and the hills rise to the height of 800 feet, sending off to the northward the lofty range of Shanklin Down, and terminating in Dumnose Point.* The siliceous nodules in these strata are always found entire; presenting in this respect a striking contrast to the shattered flints in the vertical strata that form the opposite range at Brading Down (see Pl. XIII.).

Const of The UnderchifF. - The district of the Undercliff, from the western extremity of St. Catherine's-hill to Bonchurch, is about six miles; and the road from the west passes along an irre-

* Deviation of the plnmb-line at Shanklin Down.-During the progress of the Ordnance survey, a deviation of the plumb-hine from its mean direction was observed in the neighbourhood of Shanklin Down, by Col. Colby, the Director of the Trigonometrical Survey; a considerable attraction of the plumb-line to the south of the Dunnose station having been unequivocally determined, and which is supposed to depend on the intensity of the attraction of the hill. In alluding to this remarkable phenomenon Sir Roderick Murchison (in lis address at the meeting of the British Association of Science at Southampton, September 1846) observed, "that it is a matter of surprise that this, comparatively, low chalk range in the Isle of Wight should attract, in one parallel at least, with more than half the intensity of the high and crystalline mountain of Schehallien in the Ilighlands of Scotland.a Can this be explained by the peculiar structure and distribution of the ridge of upheaved strata which runs as a back-bone from east to west through the Island? or is it to be referred to the effect of dense masses of plutonic rock ranging beneath the surface along the line of displacement of the deposits?"

a $1 n$ the year 1774 , from astronomical observations made on the mountain of Schehallien hy Dr. Maskelyne, it was proved that a sensible disturbance was produced in the direction of the plumh-line by the attraction of the dense masses of granular quartz and limestone, and mica and hornblend slate, of which that mountain is composed. 
gular terrace composed of fallen masses of chalk, marl, and firestone, which in the lapse of centuries have accumulated in a talus on the southern escarpment of the Downs. Although subsidences are occasionally taking place, and within the last hundred years, from eighty to ninety acres of the upper cliff sunk down at one time, the greater part of this singularly picturesque and lovely region has undergone no material change since the Conquest. 'This is evident from the ancient churches of St. Lawrence, and St. Boniface, which are referred by antiquaries to the elerenth or twelfth century. * In travelling from Blackgang to Ventuor, the firestone clifis are the most important geological feature. Here and there on the road side are seen accumulations of debris, and projecting crags of chert and sandstone, which from their superior hardness have for years resisted the disintegrating effect of the elements. From the intermixture of calcareous and argillaceous carth resulting from the decomposition of the strata, a soil has been produced which supports a luxuriant vegetation. Even the refractory siliceous rocks are more or less clothed with foliage, for the iry has insinuated itself into every cranny, and hangs in festoons of verdant tapestry over the cherty peaks.

* Sir Lienry Englefield; Isle of Wight. 


\section{咅 \\ $\approx$}

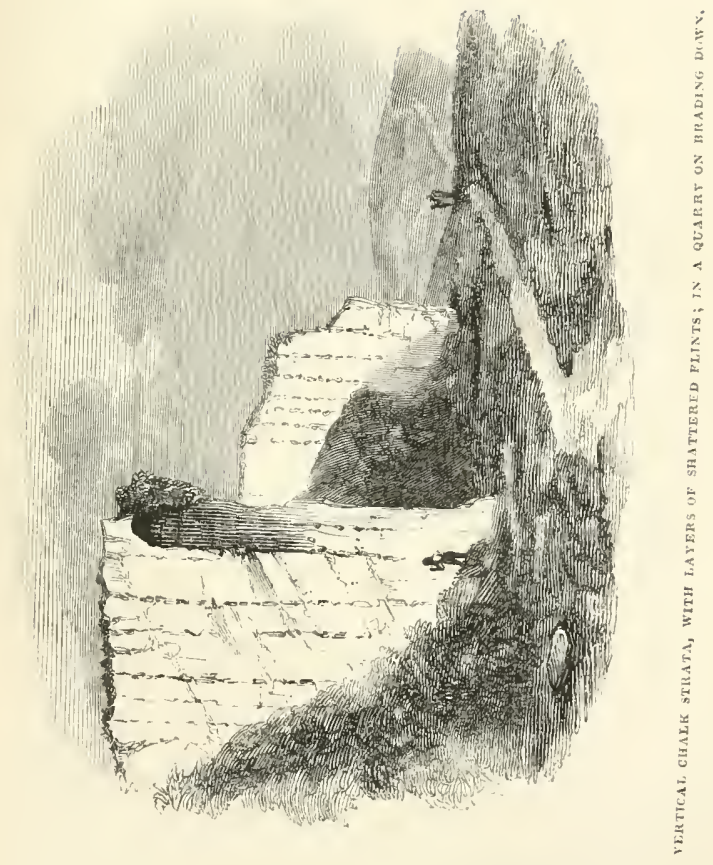



In many places the fallen blocks of sandstone are covered in relief with stems and bulbs of the Siphonia Websteri (ante, p. 243), and contain numerous shells. At Ventnor there are (or were) some bold vertical sections of the firestone; and an enormous mass of rock overhangs the road east of the Marine hotel. The calcareous sandstone here abounds in shells and molluskite. The terrace and sea-cliffs that form the southern boundary of this rapidly increasing town, are entirely composed of fallen masses of the upper groups of the cretaceous strata. In many instances huge fragments of white chalk appear imbedded in the green saud of the firestone; and I observed (in 1844) a series of chalk strata forty feet in thickness, surmounted by many feet of marl and firestone, forming a low headland on the sea-shore; the entire mass having been retroverted in its fall from the heights above. The diagram in lign. 20, p. 256, will serve to elucidate the above remarks.

The vieinity of Ventnor is rich in the shells and zoophytes of the cretaceous system. The following localities have been pointed out to me by Mr. Saxby :

The luank on the roadside at the Shute above Ventnor, abounds in Chalk-marl fossils.

Horse-shoe Bay, in black malm rock; many shellis. Under the elifl to the east, called Higleport, at low water, nodules 
of pyrites, generally having a terebratula or other shell as the nucleus.

Last of colin's Point and Mill Buy; the galt is visible and contains shells. In a highly inclined fallen mass of sandstone, sharks' tecth, eoprolites, molluskite, and many shells. Firestone with fossils occurs on the shore, eastwarl of the Parsonage.

In the gravel-pits on "Little-town Down," above Ventnor, the flints abound in sponges. They sometimes contain a sharp conical body fixed by its base and projecting into an elongated fusiform eavity. This appearance has been produeed by a belemnite, of which the large eavity is the impression, and the conical body the cast of the phragnocone, or chambered shell of this curious cephalopod.*

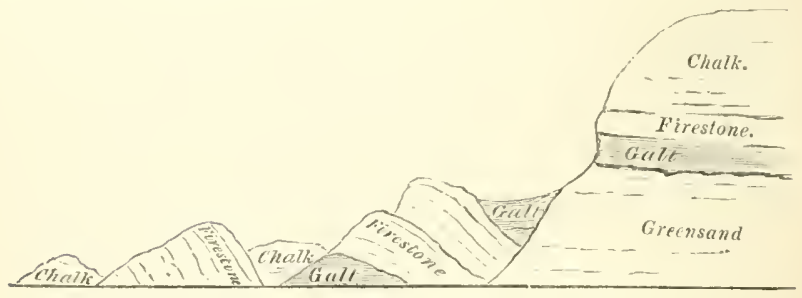

LIGN, 20.-SECTIUN OF THE UNDERCLIFF. NEAR VEXTNOR.

In the chalk marl above Boncliurch numerous fossils, comprising turrilites, seaphites, anmonites, incocerami, \&c. have been found. 'The bone of a reptile (p. 245), and the stem of Clathraria, previously described (ante, p. .244), were obtained from this locality.

- See Medals of Creation, vol. ii. p. 159. 
The coast from Ventenor to Sandown Bay. -From Rocken-end, east of Blackgang Chine, to Bonchurch, the sea-cliffs, in consequence of the displacements which have produced the Undercliff, present no continuous sections of the strata, of sufficient importance to require especial notice. It may be briefly stated, that after passing along that rumous district, and arriving at the eastem termination of the promontory formed by the southern chalk downs, a repetition of the section observable at St. Catherine's-hill on the western extremity, is presented to view on the east of Bonchurch Cove, at Dumuose Point and Shanklin Down. This section of the nearly horizontal strata of chalk, firestone, galt, and greensand, is shown in the diagram, lign. 9, p. 134. The uthite chalk forms the upper series of deposits; of the firestone, which varies in total thickness from 70 to 100 feet, a good section is seen above the ravine at Luccomb, between Bonchurch and Shanklin. The galt underlies the firestone as at Sandrock, near Blackgang; and beneath are the ferruginous sands and dark clays of the greensand; the layer of ironstone nodules full of easts of shells (see ante, p. 226) extends through the upper part of the cliff at Dumnose; but the perna mulleti bed has not been observed along this part of the coast. 
Luccomb Chine, which lies between Chine-luad and Dumose Point, is an extensive gully like that of Blackgang, formed by springs derived from the high land on the north-west, and which falling. over a perpendicular cliff of sand and clay, have worm a deep ravine that is slowly receding from the shore. 'I'he celebrated chine of Shanklin is of' the same character; the cliff here is 230 feet high, and the chasm extends 150 yards fiom the shore, being 300 feet wide at the top, and narrowing down to the bed of the torrent. The steep sides of the ravine are clothed with verdure, and overshadowed by underwood, except where bare masses of rock protrude, and contribute to the picturesque effect of this romantic glen.

The character of the scenery around Shanklin so entirely depends on the geological structure of the country, that I an led to transcribe the following vivid description of this part of the Island by Sir H. Englefield:- "As we approach the village of Shanklin, its appearance is equally singular and interesting. It is seated in a small vale hanging towards the sea, at a great height above that level; the houses are detached from each other, and ahmost buried in groves of elms ; and every cottager, however humble, being in the habit of letting lodgings in the summer season, surrounds his 
dwelling with a garden full of flowering shrubs. The whole spot has a nost cheerful and uncommon character. The little church, which is of a pretty form, stands on a broken knoll open to a beautiful pasture, with groups of elms carelessly disposed about it; and it is backed by the high hill of Dunnose, whose lower part is covered with thickets and groves hanging down its steep sides. From among these in one part a range of rocks starts out; the northern face of the same great stratum to which the Undercliff owes its existence and its beauty. The route from Shanklin church, by the road which winds through the open groves up the flank of Dumnose is eminently beautiful, affording, as we ascend, the most lovely views. The village with its groves forms a charming first distance - the bay of Sandown with the Culver Cliffs present a noble winding shore-and beyond the low land of Sandown, in the direction of Brading Haven, a part of the anchorage of Portsmouth with its shipping is visible. From the top of the ascent, the elevation of the ground is so much greater than the chalk hills of Yaverland, that the sea is visible over them; and the distant blue heights of Hampshire and Sussex form an uninterrupted line, till to the eastward they are blended with the horizon of the sea; 
emerging out of whose waters the white cliffs fiom Brighthelmston quite to Beachy-head, are distinctly visible, though from forty to sixty miles distant." *⿻

The western cliff of Shanklin Chine consists of an alternating series of clays and sands. The upper part is greenish-white sand, resting on a bed of dark-blue clay; beneath this is another stratum of sand, and a second bed of clay lying on a deposit of greenish-grey sand, with bands of sandstone. "The lower part consists of ferruginous sands, with concretionary layers of green sand full of terebratula. The argillaceous partings have given rise to narrow ledges, which are verdant from a corering of rank grass; but slips arc continually taking place from the wasting aray of the sand, by the oozing of the water arrested in its descent from the porous strata above, by tliese beds of clay.

Along this shore numerous specimens of the gryphea sinuata are generally to be met with loose in the sea-sand, as at Atherfield; and ironstone concretions full of shells, that have fallen from the clifts: in these nodules, leaflets of the Wealden fern (lign. 21) are sometimes found associated witl trigonix, terebratula, Sc.

* Sir I1. Engelfield's Isle of Wight, p. 70. 
At the foot of the cliff near Shanklin Chine, the lower series of greensand strata emerge, and gradually rising to the surface, form the western coast of Sandown Bay. The view of the bay from Shanklin is extremely interesting, for the white chalk strata of Culver form the eastern promontory, and the galt, firestone, and greensands of Redcliff, succeeded by the low Wealden cliffs, may be distinctly traced.

Beyond the cliffs at Sandown is the vale of Newcliurch, a low alluvial plain, protected from the inroads of the sea only by a thick bed of shingle; beneath which, at low water, the Wealden clay may be seen extending under the greensand strata on the east and west. The little Inn on the shore, and the Fort, now appear, and we reach the spot where our examination of the eastern side of Sandown Bay terminated.

Our excursions have now extended round the Island, and embraced the whole series of coast sections, with the exception of the Wealden cliffs that intervene between Compton Bay and Atherfield Point. A visit to Brook Bay will enable us to complete our survey, by an investigation of those highly interesting natural records, of one of the most remarkable epochs in the physical history of our globe. 


\section{CHAPTER IX.}

THE WFALIEN FORMATION-NATURE OF RIVER DEPOSITS-WEALDEY STRATA OF THE ISLE OF WIGIT-EXCERSION TO BNOOK BAY-CLIFFS FROM COMPTOS CHINE TO $3 R O O K$ POINT-BROOK POINT-PETRIFLD TREES-STRUCTLRE OF THE FOSSIL WOOD.

The Wealden formation.-The lacustrine and Aluviatile origin of the strata spread over the northern part of the Island, was clearly denoted by the prevalence of land and freshwater shells, and the remains of aquatic and terrestrial plants; and by the presence of bones of mammalia related to the Tapir, Peccari, \&c., but referable to extinct species and genera; while the marine and estuary shells, and other exuvia, in the deposits on which the fieshwater beds were superinmosed, afforded conchivive evidence that these strata were formed in the basin of a comparatively shallow sea.

The eretaceous system, which so long engaged our attention, displayed, on the contrary, an asscmblage of sedimentary deposits that had been accumblated in the profound depths of the ocean. 
in a period of unfathomable antiquity and of long duration. The inmumerable relics of marine organisms showed that then, as now, the sea was teeming with life; while a few vestiges of terrestrial plants and animals attested the existence of dry land, inhabited by oviparous quadrupeds and clothed with vegetation, during the formation of this series of oceanic deposits.

The natural records of an antecedent epoch are now before us, and we proceed to examine an assemblage of strata, not of marine, but of freshwater origin, that was deposited ere the formation of the cretaceous rocks commenced; for these fluviatile sediments constituted the sea-bottom, over which was spread the first layer of the greensand (see p. 291). From the extension of these deposits over the wealds of the south-east of England, and from their fluviatile characters having in the first instance been determined by observations on the strata and organic remains discovered in those districts, the formation has received the name of The Wealden.

Before entering upon the examination of the cliffs in Brook Bay, which will form the principal object of the present excursion, a few general observations on river deposits, and on the information to be derived from their investigation, as to the 
nature of the land, and its fanna and flora, may be necessary to cmable the unscientific reader justly to appreciate the geological interest of the phenomena that will demand his notice-phenomena which, if rightly interpreted, will reveal a former condition of the earth's surface, more marvellons than any which even the wildest imagination has ventured to portray.

Nature of river Deposits. - The torrents that rush down the mountains' sides, and the streams and rivulets that meander through the plains, are more or less eharged with earthy particles, worn from the rocks and strata over which the waters flow; and the united streams, in their progress towards the rivers, become more and more loaded with adventitious matter, and a great quantity of detritus is mechanically suspended in the water, and carried towards the sea. If the current is feeble, and the inclination of the ground but slight, a large proportion of the mud, pebbles, and gravel, subsides in the bed of the river; but the greater part is transported to the mouth of the stream, and aceumulating in the bays and creeks, and around the cmbonchure of the river, gives rise to those deposits of alluvial debris termed deltas and estuaries. But the funest particles of the detritus are carried far out to sea, by the 
currents, and finally sink down, and form layers of mud in the profound depths of the ocean. Rivers, however, convey not only the inorganic materials of the countries through which they flow, but also the leaves, branches, and trunks of trees, and other vegetable remains, and the carcases of land animals that fall into the streams, and terrestrial, lacustrine, and fluriatile shells. The remains of man and works of art are also occasionally transported to the delta, and engulphed in the mud, silt, and sand; and relics of this kind are sometimes drifted out to sea, and deposited in the bed of the ocean.

In the rivers of India and of America these operations are in daily progress on an immense scale. In the Mississippi rafts formed of prostrate forests are transported to the delta of that mighty stream, and become buried in the freshwater deposits which are there rapidly accumulating. In these sediments the remains of the animals as well as plants of the new world, are engulphed.

It is evident that should deposits of this nature become dry land, the naturalist, by an examination of the imbedded organic remains, may with certainty determine the characters of the fauna and flora of the country whence these fluviatile sediments 
were derived. Thus in the delta of the Thames he would find the bones and antlers of the deer, horse, dog, and other domesticated animals, with the leaves and branches of the elm, oak, ash and other trees and plants of our Island, with human bones, fragments of pottery and other works of art; while in that of the Ganges or the Nile, the remains of the animals and plants of India, or of Egypt would be discovered.*

To apply these data to the elucidation of the present argument. Let us suppose that the river has disappeared, that the sea also has left its place, and that the delta has become ary land; that towns and villages have been built upon the consolidated mud and sand, and that the surface of the country is either covered with woods and forests, or under cultivation. If in natural or artificial sections of these deposits, the bones of men and animals, with works of art, and the remains of plants and river shells, should be found in the clays or sands, such appearances would excite in us no surprise, because we are acquainted with the processes by which the strata were accumulated; and should an inhabitant of the new country express his astonishment how fragile shells, and delicate

* For a more extended view of this subject see Wonders of Geolngy. vil. i. p. 12. 
leaves, and bones of animals, became enclosed in the solid rock, and refusing assent to our interpretation, attribute their presence to the effect of a deluge which softened the crust of the earth, and imbedded in the sediments of its waters the remains of animated nature-our reply would be that such a catastrophe must ineritably have intermingled the relics of the animals and plants of the land, the rivers, and the ocean, and that the regular stratification of the materials, and the exclusively fluviatile and terrestrial character of the fossil remains, are fatal to such a hypothesis, and confirmatory of our explanation of the phenomena. It was by such a train of reasoning that the fluviatile origin of the Wealden deposits was established.

The strata composing the Wealden formation of the south-east of England, admit of the subdivisions given in the tabular arrangement, p. 63. Alternating layers of clays, sands, and limestones ahmost wholly composed of freshwater univalves, and of small bivalves with minute crustaceans, form the upper series. Sand and sandstones, with bands of arenaceous limestones or calciferous grits, with shells and lignite, prevail in the middle group; while in the lowermost, sands, clays and argillaceous shelly limestones again appear; and 
buried beneath the whole is a petrified forest of pine-trees with cycadeous plants, still erect in the soil in which they grew; and in all these deposits bones of colossal terrestrial reptiles are more or less abundant. The upper clays and limestones occupy the valleys of the Wealden districts that skirt the imner escarpments of the chalk downs in Surrey, Kent, and Sussex; the middle group of sands and sandstones constitutes the Forest-ridge of those counties; and the lower series appears in the deep valleys in the east of Sussex, around Battel, Brightling, Burwash, and Ashbumham. The Purbeck strata, which are characterised by thick beds of shelly limestone prineipally formed of a small species of paludina, appear on the coast of Dorsetshire, in the Island, or more properly the Peninsula, whence the name is derived. The Wealden presents the most perfect example of an ancient delta hitherto discovered; in the numerous formations comprised in the systems of Geology, there is no other instance of so well defined and extensive a group of fluviatile deposits.*

* Scarcely twenty-five years ago, though the Wealden districts were traversed daily by hundreds of intelligent persons in their journeyings to and from London and Brighton, their freshwater origin was unsuspected; the whole group being considered by Geologists as identical with the sands, clays, \&c. of the chalk formation. For though the shells forming the Sussex marble of the weald clay, were supposed, so long since as Woodward's time, to be fluviatile species, yet this point was controverted hy some able conehologists; and but few if any other organic remains had been obtalned 
The total thickness of the Wealden (inclusive of the Purbeck beds) is estimated at upwards of 1,500 feet, being equal to three times that of the delta of the Mississippi.

\section{Wealden stratia of the Isle of W'ight.-} In the Tsle of Wight but a small portion of the upper series of clays, sands, and sandstones is exposed to view. These deposits constitute the line of coast already noticed, in Sandown Bay, and the range of cliffs from near Atherfield Point to Compton Bay. The section exposed in the cliffs on the south-western coast, is shown in lign. 16,

from the strata of the Weald. Having for several years diligently collected the fossils of the south-east of Sussex, and separat-ly arranged the specimens from different localities, I was struck with the want of accordance between the organic remains from the chalk, gall, tirestone, kc. and those which 1 bad obtained from the quarries and wells, opened or sunk in the Wealden district, and by degrees, the freshwater character of the area between the green sands of Sussex, Kent, and Surrey, became manifest. The absence of ammonites, echinites, terebratulæ, corals, and other common and characteristic fossiis of the chalk, in iny wealden collection, was a circumstance that could not fail to arrest attention; and the discovery of the bones of large reptiles, with the leaves and stems of ferns, cycadeous plants, \&c. in the strata of 'I ilgate Forest, of which there were not the slightest traces in the cretaceous deposits, corroborated the inferences suggested by my previous observations. In 1822 the Tilgate strata were first described, ant their freshwater origin pointcd out in "The Fossils of the South Downs." In June 1822, I communicated to the Geo!ogical Society of London an account of the extensiou of these strata over Sussex, bcing the result of my own and Mr. Lyell's observations. In 1827, "The Fossils of Tilgate Forest," containing nearly 200 figures of wealden fossils, was published. See Dr. Fitton's charning little work; "A Gerlogical Sketch of the vicinity of Hastings." London, 1832. p. 13.

* The delta of the Mississippi is computed by MI. Lyell to be 528 feet, or about the tenth of a mile in depth; the area it covers 13,600 square statute miles; the solid matter annually added 3 billions 700 millions cubic feet ; and the period required for its formation, many thousand years. 
270 GEOLOGY OF THE ISLE OF WIGHT.

(p. 215), from Dr. Fitton's Memoir; to which reference must be made for details, which though of great value in a scientific point of view, possess but little interest for the general observer.** The Wealden strata forming this line of coast, consist of laminated clays, shales, and loosely colierent sands, full of freshwater shells and crustaceans, with lignite, and in some strata abundance of pyrites; layers, a few inches in thickness, of tough bluish aroillaceous shelly limestones, some being composed chiefly of bivalves, and others of univalves; sands, with concretionary nodules of calcareous compact grit and sand-rock; and variegated clays, mottled with different shades of red, yellow, blue, green, and grey; waterworn bones of reptiles occur throughout. But the subdivisions of the Wealden are in a great measure arbitrary, for the same fossils, and the same lithological characters, pervade the entire series. Beds of sands, clays, and argillaceons limestones, and calciferous grits, almost identical in mineral composition, and containing similar organic remains, are found alike in the upper and lower part of the series; indicating a similar condition of the land and water throughout the Wealden epoch. In that part of Sussex orer which my

\footnotetext{
* Geol. Trans. vol, iv. second series, p. 197-220.
} 
earliest researches extended, the univalve limestones (Susex marble) and sluales, predominate in the upper series; sands and calciferous grits alternating with clays in the middle; and bivalve limestones and clays in the lower division. But in the Isle of Wight, the clays and limestones with bivalves, are as abundant as those with univalves; and slabs from Sandown and Compton Bays, could not be distinguished from the shelly limestones of Ashbumham and Battel in Sussex.*

Excursion to Brook Bay.- The Wealden strata extend between six and seven miles along the coast; we have already noticed their emergence from beneath the greensand at Atherfield Point (ante, p. 224), and at Compton Bay (p. 216). From Compton Chine to Brook Chine, a distance of but little more than two miles and a half, the most interesting phenomena may be examined in a stroll along the beach, which should be undertaken at the ebb of the tide, to allow of sufficient time for the collection of specimens. If a brief visit only be contemplated, the tourist should drive to Brook, and within a short distance of the

* It may be worth inquiry whether the Wealden strata of the Isle of Wight really belong to the upper division-whether they may not be referahle to a lower group, and the superior beds have been destroyed by the incursions of the sea, before the delta subsided and the greensand was deposited upon the now uppermost bed of clay? 
chine, ${ }^{*}$ and he may alight within a few hundred yards of the most interesting spot-the fossil forest at Brook Point. The most farourable season for a geological examination of this part of the coast is the early spring - the latter end of March or the beginning of April-for at low water a great extent of sand is laid bare, and reefs of Wealden sand-rock are seen stretching far out to sea; and the ligh tides often sweep away the shingle from the base of the cliffs, and the lowermost visible strata are exposed. The chance of obtaining fossil bones is also greater at this period of the year than at any other, owing to the inroads of the sea on the clay eliffs, and the consequent dislodgment of any bones they may contain; and as these relics are very heary from an impregnation of pyrites, they fall on the shingle, and are left by the retiring waves.

We shall commence our ramble at the foot of Compton Chine, near which place fossils of the Greensand and of the Wealden alike abound.

Chiffa from Compton Cirne to Brook Point. -The description of the coast as seen from the foot of $\Lambda$ fton Down, given on our previous visit to Compton Bay (p. 210, $\%$. XI.), and a reference to the sections in lign. 16 and 17 ,

* There is no $1 \mathrm{nn}$ near the spot, but accommodation for horses may be obtained at a neighbouring farm-house or cottage. 
p. 215, and to the map ( $P l . \mathrm{XX}$.), will afford the necessary information as to the geological relations of the strata we are about to examine. As we descend to the sea-shore near Compton Chine, the top of the cliff, to the depth of ten or twelve feet, is seen to be composed of drifted gravel, clay, and loam; and this alluvial covering continues for several miles along the coast, forming, as shown in the annexed sketch (Pl. XIV. p. 2\%4), a horizontal bed upon the edges of the inclined strata of which the lower part of the cliff consists. In this accumulation of drifted materials are numerous trunks of trees and quantities of hazelnuts, in the usual condition of peat or bog-wood. The trunks are several feet in length, and a foot or more in diameter; the ligneous substance is very black and soft when first extracted, but hardens after exposure to the air, and some of the wood is so firm in texture as to be employed for various domestic purposes. I could not learn that any bones had been found in this subterranean forest, but I picked up, on a bank hard by, teeth of the horse and deer, which were deeply stained with phosphate of iron, and probably belonged to this alluvial deposit.

The Wealden strata to the east of their junction with the greensand, principally consist of clays, 
with seams of shale and sand, and layers of shelly limestone; the appearance of the face of the cliff formed by these strata is shown in Pl. XIV. In this view the nearest headland is Bullface Ledge; that beyond, which extends far out to sea, is Brook Point, the western extremity of the Bay; that in the far distance is the eastern boundary of the same. The view of Brook Point from Afton Down (Pl. XI. p. 210), shows the continuance of the clifis from beyond Bullface Ledge and Brook Bay to Blackgang Chine.

Masses of the Wealden clay with freshwater shells, in connexion with the greensand containing marine shells, should be the first objects of research. Mr. Morris was so fortunate as to obtain from this spot, a mass in which specimens of a very characteristic univalve (Potamides carbonarius, Pl. VI. fig. 5) were imbedded. Waterworn blocks of the shelly limestones ( $\mathcal{\prime}$. VI. figs. $2,3,4)$, and rolled fragments of bones washed out of the cliffs, will be found in abundance in the shingle. Slabs of the freshwater limestones may be observed in the cliffs at an accessible height; and specimens of the shale covered with cyprides and shells, may be obtained from the fallen masses on the shore.

The laminated clays and shales are succeeded, as we advance castward, by mottled plastic clays, 
运

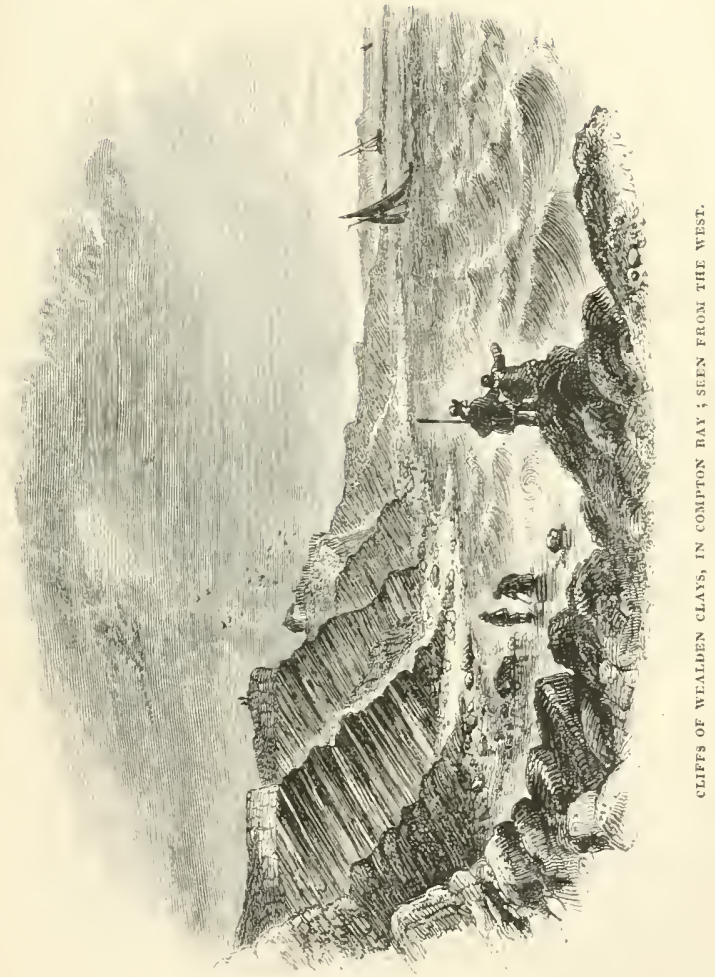



containing bands of reddish and yellow sand, and hard grit or sand-rock; and the strata gradually decline till we reach Brook Bay, where they are nearly horizontal.

From Bullface Ledge we perceive the low promontory of Brook Point that forms the eastern boundary of Compton Bay, and at its base a reef of rocks extending seaward to a considerable distance. If the tide is very low, a succession of ledges of this kind are visible along the shore, stretching out to the distance of half a mile or more from the land, and indicating the former extent of the southern coast of the Island, at a comparatively very modern period. These reefs and rocks consist of the harder masses of the Wealden sandstone, which have resisted the destructive effects of the waves, after the clays, sands, and softer materials, have been swept away.

Brook Pornt.-As we approach Brook Point, the variegated sands and grit which lie beneath the clays, become more developed; and large waterworn blocks of sandstone appear here and there on the shore. The ledge at the base of the cliff, which formed so prominent a feature of this part of the coast when seen from a distance, consists of indurated sandstone inclosing 
trunks and branches of large trees completely petrified, many of which are strewn along the strand, and half buried in the sand and shingle. The projecting masses at the foot of the cliff are the broken edges of the strata, and the trunks of fossil trees; the upper and less coherent deposits having been washed away.

'The cliff is between thirty and forty feet high, and is capped by the bed of loam and gravel previously noticed at Compton Chine. Beneath this alluvial covering are laminated clays and shales, and sand and friable sandstone, abounding in masses and layers of lignite; and minute particles of the same substance are disseminated throughout the strata. Pyrites occurs abundantly in small nodules and spheroidal masses; and this mineral generally pervades the lignite and wood. Towards the base of the cliff, are the beds of sand and sandstone with hard concretionary grit, containing the fossil trees; and beneath these are seen, at low water, compact variegated sands, which are the lowermost deposits in the Island. East of the Point is Brook Chine, a deep fissure or chasm that has been worn in the softer strata by the long continued erosion of a stream, which gushes out from beneath the sand beds inland, and flowing through the atluvial 
gravel to the top of the cliff, falls in a cascade to the sea-shore.

Petrified Trees. - The prostrate fossil trees at Brook Point were first noticed by Mr. Webster thirty years ago.* After describing the clays and sandstones of the cliff, Mr. Webster states that he "observed many masses of" a coaly blackness, bearing the exact form and resemblance of trunks of trees that had been charred, lying on the beach, and imbedded in the clay-cliffs, and also in the rock. In some parts the ligneous fibre was still evident; in others the wood had been converted into a substance much resembling jet, its blackness being intense, its cross fracture conchoiclal, and its lustre very great. Other parts of the trees were entirely penetrated by pyrites, and groups of crystals of this substance were frequently attached to the outside. On lifting up some of the sea-weed, that grew upon the shore between high and low water-mark, I was astonished to find almost all the rocks below them composed of petrified trees which still retained their original forms. The knotty bark and ligneous fibre were very distinct; and trunks and branches were frequently imbedded in masses of clay now indurated and in the state of argillaceous rock."

* sir H, Englefield's I sle of Wight, 1) 153. 
Upon firstreading the above description, my curiosity was strongly excited, and when in the course of my researches in the strata of the wealds of Sussex, the fluviatile origin of those deposits became evident, I felt an irresistible desire to visit Brook Point, in the expectation of beholding a petrified forest of the country that had been inhabited by the colossal reptiles, of which so many remains liad been discovered in Tilgate Forest. Nor was my expectation disappointed; I have visited this coast many times, and always with increased interest-an interest which I hope to excite in some of my intelligent readers, and induce them to repair to the spot, and investigate the phenomena, of which these pages can present but a feeble outline.* The trees are all lying prostrate and

* In June 1823, my friend Mr. Lyell visited compton Bay for the purpose of ascertaining more clearly the relations between the ironsand of $\mathrm{Mr}$. Webster, and the strata of Tilgate Forest, of which an account had appeared in my "Fossils of the South Downs." In a letter detailing the result of his investigation, Mr. Lycll remarks:- "At Compton Chine 1 found in Webster's blue narl, several small lnocerami (1. sulcatus) and some other characteristic shels, so that I believe the identity of this bed with the Folkestone galt might be made out by further research. The section from Compton C'hine to Brook is superb; we see there at one biew the whole Geology of your distriet, from the Clalk with tlints down to the Battel beds, and all within an hour's walk.-This is so beautiful a key, that 1 an at a loss to conceive how so much eonfusion has arisen.-The softness of the weald elay has caused a ruinous state of the cliff just where the Sussex marble ought to be. Soon after this, layers of limestone with bivalves appear; then some mottled beds; then pyritous coal (lignite) like that at Bexhill J presume._- In Sandown Bay I picked up a block of letworth marble two feet in diameter, of which and the other rocks 1 will send you specinens." 
confusedly intermingled. There are 110 erect trunks, nor any other indications that the forest was submerged with its native soil, like that of the Isle of Portland.* On the contrary, this accumulation of fossil trees resembles the rafts, as they are termed, that are anmually brought down from the interior of the country by the tributary streams of the great rivers of North America, and which, hurried along by those vast floods, entangle in their course the remains of animals and plants that may happen to lie in the beds of the rivers, or be floating in the waters. These rafts are at length drifted out of the course of the currents, and becoming loaded with mud, sand, and other extraneous matter, sink down, and are engulphed in the bed of the delta. $\uparrow$

The fossil trees at Brook Pcint appear to hare been submerged when arrived at maturity, and while fresh and vigorous; for the trunks before removed from the sandstone, are invariably corered by the bark in the state of lignite. This cortical investment quickly disappears when the stems are exposed to the action of the waves; but the ligneous structure, which is converted into a very hard calcareous stone, for a long while resists 
destruction. Trumks and branches, from a few inches to three feet in diameter, and many feet in length, are in general to be seen lying on the shore between high and low water mark; and in these specimens the texture of the wood, and the ammular lines of growth on the waterworn transverse fractures, are strongly defined. On a late visit there were two stems which could be traced to a length of twenty feet; and they were of such a magnitude as to indicate the height of the trees when living at from forty to fifty feet. Many stems are concenled and protected by the fuci, corallines, and zoophytes, which here thrive luxuriantly, and occupy the place of the lichens and other parasitical plants, with which the now petrified trees were doubtless invested when flourishing in their native forests, and affording shelter to the Iguanodon and other gigantic reptiles.

Structure of tue Fossu, wood.-These fossil trees are calcareous, not siliceous like those of Portland. The wood is more or less traversed by reins and filaments of pyrites, which impart a beautiful appearance to polished specimens of the stems. Slices rendered transparent by Canada balsam, exhibit under the microscope, in the transrerse sections, the cellular tissue as a reticulation of polygonal meshes; and in the radial, 
the ducts or glands characteristic of the Coniferæ, and arranged in alternate rows as in the Araucaria or Norfolk Island Pine.* The annular lines of growth are often very distinct; I have traced from thirty to forty on some of the stems. These circles are of unequal thickness, and therefore indicate a variation from year to year in the climate of the country in which they grew. They are, too, as small as in the slow growing pines and firs of England. Many of the stems exhibit an obliquity in the annular lines, proving that they grew in situations which exposed the trees to prevailing currents of wind from a particular quarter, and caused them to incline in the opposite direction. I have discovered no vestiges either of the foliage or fruit. It is remarkable that coniferous wood occurs but sparingly, if at all, in the Wealden deposits of the south-east of England; but drifted stems and branches of pines of the araucarian type, are common in some of the upper beds of the greensand, and are occasionally met with in clialk flints.

Such is a brief description of the accumulation of fossil trees at Brook Point, which evidently originated in a raft composed of a prostrate

* See Medals of Creation, vol. i. p. 7 .

† Medals, vol. i. p. 168 . 
pine-forest, transported from a distance by the river which flowed through the country whence the Wealden deposits were derived, and became submerged in the sand and mud of the delta, burying with it the bones of reptiles, mussel-shells, and other extraneous bodies it had gathered in its course.

In the strata that overlie the fossil forest, thin interrupted seams of lignite, * and masses of the same substance invested with crystals of brilliant pyrites, are every where abundant; and beautiful and instructive specimens may be obtained. + In the clays for several hundred yards both to the east and west of Brook Point, bones of the Wealden reptiles are numerous; with these are associated large mussel-shells (Pl. VI. fig. 1), and lignite. 'To the east of Brook Bay is Brixton Bay; and along this line of coast, as far as Atherfield, similar organic remains are continnally met with after the high tides of the early spring. I have not examined the cliffs further to the castward, and must refer to Dr. Fitton's Memoir for a particular enumeration of every important

- I.ignite, sc.-for an aceount of the clianges by whieh vegetable substances are converted into lignite, coal, \&c., see Midals of Creation, vol. i. chap. 5.

1 Unfortunately these sprecimens generally fall to pieces after a few months, in conseguence of the decomposition of the pyrites with which they. are permeated. 
stratum, along the southern coast of the Isle of Wight. My attention has always been so much engrossed by the interesting phenomena obserrable in Brook Bay, which is at all times easy of access, that I have had neither leisure nor inclination to extend my researches to the east of the point above mentioned. Dr. Fitton states that in the cliff at "Tieprit and thence to Shepherd's Chine, and within that chine and Coulease Chine, the Wealden clay and its passage to the sands beneath, are better displayed than in any other localities."*

* Geol. Trans. vol. iv. p. $19 \mathrm{~s}$ 


\section{CHAPTER X.}

ORGANXC REMAINS OF THE WEALDEN-FOSSIL VEGETABLES-ENDOGENITES EROSA-CYCADEOUS PLANTS-CLATHRARIA LYELLII-FOSSIL SHELLS-UNIO VALDENSIS-FOSSIL CYPRIDES-FOSSIL FISHES.

Fossils of The Wealden.-The Wealden strata of the Isle of Wight have afforded examples of the most characteristic organic remains that have been discovered in this formation in other parts of England. They have yielded five or more genera of terrestrial plants; of which one belongs to the Pines, several to the Cycadex, and two or three to the Ferns: several species of river-shells, of the genera Unio, Paludina, Potamides, Cyclas, \&c.; and of the small crustaceans, the Cyprides. Fishes atlied to the Bony-pike and the Sharks oceur, and bones of seren or eight species of terrestrial saurian reptiles, and of two or three genera of Chelonians.

Fossil vegetables. - Our description of the fossil forest of Brook Point entered so fully into the character of the coniferous trees of the Wcalden, that it is unnecessiry to enlarge upon 
that subject. A great proportion of the lignite in the laminated sands and clays forming those cliffs, is undoubtedly the bark of the mature trees, and the wood of the young plants, in a carbonized state.

But the coaly particles disseminated through the strata have probably, in a great measure,

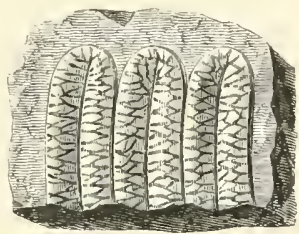

1.

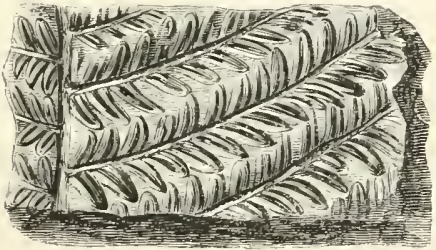

$\approx$.

LIGN, 21.-A Fossí FERN (Lonchopteris Mantelli) FFoM THE WEALD CLAY; BROOK POINT.

Fig. 1.-Portion of three leaflets, magnified, to show the reticulations of the veins.

2.-Part of a stem, with leaves.

originated from the foliage of two elegant extinct species of ferns, that abound in some parts of the Wealden of Sussex, and of which a few recog- 
nisable specimens have been discovered in the Isle of Wight.

Fossil Ferns.-Entiue layers of the sandstone, grit, and shale, in Tilgate Forest, are so full of carbonaceous matter as to acquire a dark mottled colour, and this detritus is composed of mimute particles of the leaves and stems of ferns, that have been ground to pieces by agitation in water loaded with sand and mud. One of these plants (Spleenopteris Mantelli, "Wonders of Geology," p. 370) is characterised by its slender wedge-shaped leaflets. The other fern (Lonchopteris Mantelli, lign. 21) is the species already mentioned as oceurring in the greensand of Atherfield and Shanklin. It is distinguished by its long and many-times pinnated leaves, and the reticulated disposition of the secondary reins that spring from the mid-rib of the leaflets.

Endogenites vRosa.-In the strata of Tilgate Forest, and in the sands at Hastings, numerous fragments of the stems of a remarkable monocotyledonous (?) plant oceur, and are mentioned in my Fossils of the South Downs, and figured in the Fossils of Tilgate Forest, \&c. 'These stems are of various forms; some are cylindrical, and tapering at both ends; and others are flattened, and of a clavated shape, like some of the Cacti and Euphorbia; the 
specimens are from a few inches to seven or eight feet long, and the largest from twenty to thirty inches in circumference. When imbedded in the strata, a thick coat of lignite surrounds the stem; but this soon becomes friable, and falls off after exposure to the air. The constituent substance of the stems is a grey, compact, subcrystalline sandstone, and the external surface is traversed by fine semicircular grooves and deep tubular furrows, lined with minute quartz crystals; a transverse section exhibits the surface covered by small pores, and a few large openings, the sections of the tubes. From the eroded appearance of the surface of the specimens, when deprived of their carbonaceous investment, the name Endogenites erosa was given to this fossil plant by Messrs. Stokes and Webb, who described it from my specimens, in the Geological Transactions, vol. i. second series. Dr. Fitton * subsequently described and figured a series of interesting specimens observed by him in the strata at Hastings. In transverse slices of these fossils, obscure indications of circular bundles of vascular tissue were detected, but (as in all my specimens from Tilgate Forest) very few restiges of organic structure were apparent; the cavities exposed in the sections being 
not the vessels themselves, but the hollows left by their decay.* The oceurrence of this fossil plant in the Wealden of the Isle of Wight has only recently been discovered. Among the waterworn fossils which I collected from the shingle, on my last visit to Brook Point, was a rounded, subeylindrical block of sandstone, very smooth, and marked externally with small crescent-shaped spots, which are the terminations of bundles of vascular tissue.

A transverse section of this fossil proved it to be a portion of the stem of the Endogenites erosa, in a better state of preservation than any example previously obtained. The openings, instead of being: empty, are for the most part occupied by the vessels; and an extemal band, or zone, of vascular tissue, disposed somewhat in festoons, is tolerably well preserved. Very thin slices, immersed in Canada balsam, to render them as transparent as the dull siliceous substance of which they are composed will admit of, examined under the microscope, indicate, in the opinion of Dr. Robert Brown, a nearer approach to the Cycadea than to the Endogenous tribes.

Fossil cycadeous plan'ts. - Among the coniferx, or cone-bearing plants, the Cycadec and

\footnotetext{
" Dr. Fitton has given magnified figures of the seetions in his pl, xx.
} 
Zamice are remarkably distinguished by the peculiarity of their fructification, their seeds being exposed; hence the name of the order in which these plants are arranged - gymnospermous, i. e. naked seeds: the organization of their stems is also different from that of the other coniferæ.** As several species of Zamia and Cycas are cultivated in our greenhouses, their general aspect, which approaches that of the palms, must be familiar to the reader. Most of the Zamiæ are short plants, with stout cylindrical stems, beset with thick scales, which are the petioles, or leaf stalks, left after the leaves have fallen off. On the summit of the stem is a crown of elegant pinnated leaves, with simple veins. The fruit bears some resemblance to the cones of the pines, but the seeds are not enclosed in receptacles. The Cycadece resemble the Zamia, but the trunk is in general longer; one species, Cycas circinnalis, attains a height of thirty feet. The stem is in most species simple, but in some it is dichotomous, dividing into two or more branches; the leaves are tough, and in the young state coiled up like a crosier, as in the ferns. These plants are inhabitants of hot and humid climates, and abound in the West Indies, Molucca Isles, \&c. A few plants of this order

* See Dr Buckland's Bridgwater Essay, p. 490. 
have been detected in the carboniferous strata: and in the Lias and Oolite they appear in immense numbers; several species have been found in the Wealden, and cretaceous formations. The discovery of cones of a species of Zamia (Z. crassa, "Medals of Creation," p. 160), associated with bones of the iguanodon, in the Wealden strata in Sandown Bay, has already been mentioned (p.138).

Clatmirara Iyelli.-But the most interesting fossil plant belonging to this tribe of conifera, of which any remains have been found in the IVealden, is that discovered by me in Sussex, and described in 1822; and subsequently in "' $\mathrm{I}]_{1}$ Fossils of 'Tilgate Forest," under the name of Clathraria Lyellii.*

This plant was formerly classed with the Lilircee, by that minent botanist M. Adolphe Brongniart; but the discovery of more illustrative specimens than those first obtained, indicate its affinity to the Cycadea, with which M. Brongniart has some years since armanged it. The stem of the Clathrariat is composed of an axis having the surface covered with reticulated fibres, and of a false bark produced by the union of the consolidated

* lossils of 'Tilgate Forest, l'lates I. II. 111., and Geology of the Southliast of England, P. I.

I chulhroria, or latticed stem; so named from the scorings left on the stem by the attachment of the petioles. 
bases of the petioles, the insertions of which are rhomboidal and transserse. The external surface of the stem is in consequence covered with lozengeshaped elevated scars, separated by lateral depressions, which are surrounded by a parallel band of a fibrous appearance (see lign.22). 'This outer portion is sometimes consolidated into a compact cylinder of stone, which will separate from the central axis

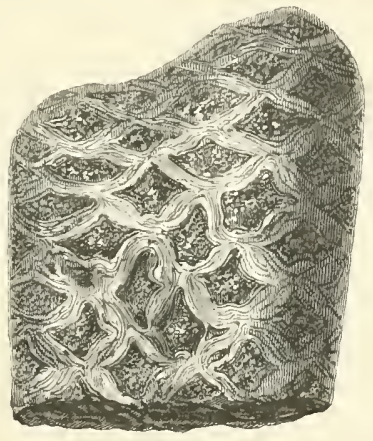

LIGN. 22. WATERWORN STEM OF THE CLATHRARIA LXELIII,

From the shingle in Brook Bay.

(One-liird linear, nat. size.)

(Foss. Tilg. Forest, Pl. II.): the latter is solid, and strongly marked externally with reticulated interrupted ridges. This surface has generally patches of vascular tissue adhering to it, but these are in so friable a condition, that microscopical 
examination has thrown no light upon their structure.* On some parts of the internal axis there are deep pits, indicating the lacunæ in which a resinous secretion was contained.

The waterworn portion of a stem, figured in lign. 22, which I picked up on the sea-beach in Brook Bay, is the only specimen of the Clathraria I have seen from the Wealden of the Isle of Wight. This fragment is highly interesting, for the calcareo-siliceous earth of which the stem now consists, is of a finer texture than in any of the Tilgate Forest specimens, and transverse sections display under the microscope more satisfactory indications of the organization of the original. Without many figures, and more lengthened descriptions than our space will admit of, the peculiarities of structure exhibited in these slices, could not be demonstrated; it must therefore suffice to state, that the organization, so far as it can be determined, shows a near approach to that of the Cycadere.

But additional and most important information as to the extcrnal form of the Clathraria, has been afforded by the splendid specimen from

- For other details 1 must refer to the "Medals of Creation," vol.i. p. 182. All the specimens figured in my previous warks are in the British Museum, in the room appropriated to fossil vegetables. 
the chalk marl of the Undercliff, mentioned in a previous chapter (Chap. VIII. p. 244), as having been discovered by Captain Ibbetson, and now exhibited in his collection of Isle of Wight fossils, in the Polytechnic Institution. This invaluable relic is admirably represented by Mr. Dinkel,* and engraved by Mr. Lee, in lign. 23, p. 297.

This specimen consists of the summit of the stem, and is fifteen inches in length; the appearance of the lower end shows that some portion has been broken off and lost. The stem is compressed into an elliptical form ; the figure exhibits the longest diameter, and the side on which the characters of the plant are best preserved. On the upper $10 \frac{1}{2}$ inches, this trunk is covered by the petioles or leaf-stalks; and these appendages remain on one side almost to the lower extremity. The surface of the inferior portion, to the extent of four inches, is marked with transverse lozengeshaped scars, produced by the separation of the petioles; the internal axis appears at the fractured end: see lign. 23, $a$. The leaf-stalks are from

* This eminent artist now permanentiy resides in London; being engaged at the British Museum by Dr. Falconer, on the illustrations for the important work on the Sub-Himalayan Fossils, which is now in progress of publication. For subjects requiring talent, accuracy, and knowledge of animal and vegetable organization, for their successful delineation, the pencil of Mr. Dinkel will be found invaluable. 
one to two inches wide, rounded above, and contracted below, as shown in the detached petiole figured in lign. 21; they are traversed by fine and nearly parallel longitudinal veins. The sum-

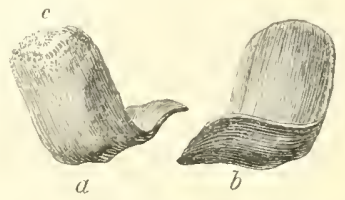

L. I 1 N 24 .

A PETIOLE OF CLATHRARIA LYELLII, SEPARATED FROM THE STEM.

a, the extermal aspect ;

$b$, the internal surface:

$c$, the vascular markings left on the summit of the petiole by the separation of the leat.

mits of those petioles from which the leaves appear to bave been shed, not broken off, are marked by rascular pits disposed with great regularity, as shown at $r$, lign. 24 ; a structure which M. Adolphe Brongriant informs me partakes more of the character of the Ferns, than of the Cycadea. 'The substance of this fossil is a sandy. marl, and probably does not retain any traces of the internal structure of the original; still it is desirable that sections of the petioles, and of the stem, should be microscopically examincel. M. Adolphe Brongniat, to whom I transmitted 


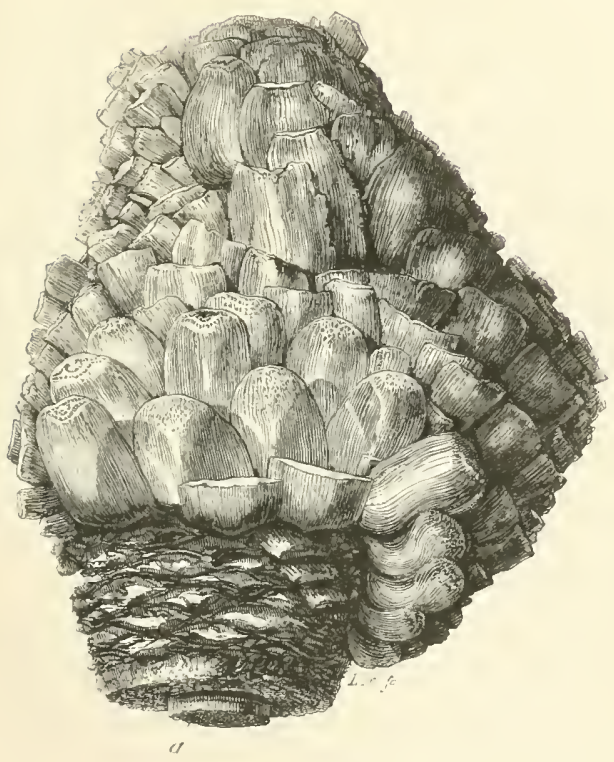

L1GN. 23.

From the Chalk-marl at Bonchurch, Isle of Wight; discovered ly Captain IbBetson.

This fossil is the summit of a stem garnished with petioles or leafstalks on the upper part: from the lower portion the petioles have been removed. The internal axis is seen at $a$. The original is fifteen inches in length; and eleven and a laalf in the widest transverse diameter. 
a sketch of this specimen of the natural size, immediately faroured me with his remarks on this interesting fossil. He considers the specimen to be the upper termination of a stem of the Clathraria, garnished with persistent leaf-stalks; and that some of the uppermost petioles were broken off accidentally while the leaves were alive; but that in the lower ones which possess vascular markings on their summits, the leaves were detached naturally, and these petioles remained, probably for some years, as is the case in the existing Cycadex. The petioles having fallen from the exposect part of the stem, the surface is left bare, and is marked by lozenge-shaped cicatrices or scars, which are the points of attachment of the bases of the leaf-stalks.

On the other side of the specimen there appeared to me indications of the foliage, but M. Brongniart suggests it as more probable, that they are only elongated and flattened petioles.

'The occurence of this very characteristic plant of the Wealden high up in the chalk formation, is in accordance with the discovery of the bones of the Iguanodon in the greensand of Kent.* In the strata of 'Tilgate Forest the remains of the Clathrarix are invariably associated with water- 
worn bones of reptiles, and pebbles, gravel, and other drift, and are often imbedded in the fluviatile conglomerate which occurs in some parts of the Wealden.* They appear to have floated down the river with the carcases and limbs of the reptiles, and at length to have sunk to the bottom and become imbedded in the mud and sand of the delta.

Fossil shells. - The shells of the Wealden of the Isle of Wight belong to the same genera and species of fluviatile mollusca, as those in the contemporaneous deposits of the south-east of England: and though spread over areas of considerable extent, and through deposits of great thickness, they comprise but a few species-a characteristic feature of the fauna of all rivers. The substance of the shells in the limestones is for the most part changed into carbonate of lime; but the shells in the argillaceous strata are often but little altered, and sometimes occur in as perfect a state as in very recent deposits; the epidermis and even the horny ligament being preserved. In the coarse limestones the shells have generally perished, and casts only remain.

Sussex and Petwortu marble.-The most

* See remarks on the "Discovery of the Hylæosaurus," in Wonders of Geology, vol. i. p. 401. 
abundant univalve shells are four or five kinds of Paludina; a common river snail, of which there are species in the tertiary freshwater strata of Headon Hill and Calbourne (sce Pl. I. fig. 6). Numerous beds of marble, coarse limestone, clays and shales, abound in, or are wholly made up of paludinæ, and minute crustaceans. The compact Sussex limestone, which from its taking a good polish, is called marble, principally consists of the shells of one large species, the Paludina fuviorum (Pl. VI. fig. 3), held together by an infiltration of crystallized carbonate of lime; the cavities of the shells, and the interstices between them, being often filled with white calc-spar. Upon examining thin slices of this marble under the microscope, the shells are found to contain myriads of the cases of Cyprides (lign. 25). The Purbeck marble differs from the above in being composed of a much smaller species - the Paludina elongata (P7. VI. fig. 2).

These marbles were in great repute with the architects of the middle ages, and there are but few of our cathedrals and amcient churches which do not still contain examples of both varieties, either in their columns, sepulehral monuments, or pavements. 'The polished cluster-columns of the Temple Clurch in London, and many of the monuments 
in Westminster Abbey, are of Purbeck marble; in other words, they are composed of the petrified shells of snails, that lived and died in the rivers which flowed through the country inhabited by the extinct colossal reptiles. The dark masses and veins so common in these marbles, are the remains of the bodies of the mollusca, changed into the carbonaceous substance termed molluskite (see ante, p. 248). The shells which were empty at the period of their becoming imbedded, had their cavities filled with the mud, silt, \&c. which are now clay, marl, and limestone; but in the shells containing the animals, the gelatinous parts were converted into molluskite. In polished sections of the marbles this substance appears either within the shells, or in black or dark brown masses, and veins: the most beautiful slabs of Sussex marble owe their variegated markings to the contrast produced by the black molluskite with the white calcareous spar.

Potamides. - Some species of the elongated, spiral, freshwater univalves, termed Potamides, of which several occur in profusion in the strata at Headon Hill (see $P l$. II. figs. 2, 8, 9), are found in the Wealden. A very characteristic shell, the Potamides carbonarius, is figured in Pl.VI. fig. 5: this species was first discovered in the weald clay 
at Pounceford in Sussex.* It also occurs in Hanover, in the clays interealated with beds of coal, belonging to the Wealden formation.

Fossil fresinater bivalues. - Many of the bluish grey argillaceous limestones, as we have before remarked, are chiefly composed of five or six species of bivalves of the genera Cyclas and Cyrena; a small slab with several shells in relief, is represented $P l$. VI. fig. 4. Large blocks corered with shells of this kind, are commonly to be found along the base of the eliffs, at Brook, Compton, and Sandown bays; and in the clays, there are numerous seams of crushed shells of these genera. The hard grits often abound in casts of Cyclades, associated with a small species of rirer-mussel (Unio); and some layers of Sussex marble contain an intermixture of these shells with the paludinx.

Unio Valdensis. Pl. VI. fig. 1. - The only other bivalves which occur in any considerable number in the Wealden, are the mussels termed Unionide; a family of testaccous mollusca containing several genera, and comprising many species of considerable magnitude. These animals have a solid pearly shell, with two principal and two lateral teeth on the linge. In number, varicty, and internal lustre, the Uniones of the large 
rivers of North America, present a striking contrast with the few and homely British species. In a fossil state Uniones are rare; a few occur in the carboniferous strata, and these with eight or nine small speeies from the Wealden, figured by Dr. Fitton and myself, comprise all that are known in our secondary strata.

Many of the slabs of limestone procured from Sandown Bay, and used in the pavements at Brading, Ryde, \&e. display sections of a species of Unio, which is common in some of the Petworth and Purbeck beds. On a visit to Brook Point in 1848, I discovered a remarkably fine and large species of Unio in the eliff above the petrified trees, and have since collected many specimens of this interesting fossil, which I have proposed to distinguish by the name of Unio Valdensis, or Wealden river-mussel. A small and young example is figured in Pl. VI. fig. 1 ; the hinge, and the anterior muscular imprints, are shown in the upper figure. The specimens obtained from the cliff's are in an excellent state of preservation; the surface of the shell, which is but little worn, is of a tawny-red colour, like some of the recent Ohio species. Even the horny ligament with its transverse rugæ remains; and in some instances the shell is oecupied by the body of the animal in the 
state of molluskite. 'The constituent substance of the shell is occasionally changed into calcareous spar, and admits of a fine polish; nodules of erystallized sulphate of barytes of a pink colour, are not uncommon within the shells. Some examples which I extracted from the bed containing the fossil trees, are partially invested with lignite. One pair of valves has been separated, and the hard grit with which they were filled cleared away, so as to develop the characters of the hinge, \&c.

The shell is of an orate form, from four to six inches long, three inehes in altitnde, and two inehes in thickness or diameter; the weight of a pair of valves eleared from extraneous matter is eleven ounees. The shell is equivalved, sub-equilateral, the posterior balf one-fifth longer than the anterior, and compressed along the margin of the anterior slope. It is very thiek and strong, and marked externally with longitudinal strix. The summit is rounded, antero-dorsal, and slightly inelined forward; the umlones are deeortieated, as in most of the shells of the Unionida. The ligament is external, post-apieial, and marked with transverse rugat. The base or cireumference of the shell is entire; the margin or internal lip is thick and flat. The inner surface is smooth, with the exeeption of a few irregnlar projections of nacreous deposit. The hinge is dorsal, the hinge-plate very thick with a deep forse beneath the lamellar portion. 'I'he eardinal teeth of the right valve are two; the anterior one is the largest, and bifureated; the lamellar tooth-plate is broad. The anterior musenlar imprint is in front of the large cardinal tooth, and immediately behind this impression is the indentation left ly the attachment. of the retractor muscles of the foot. The posterior museular imprint is placer at the extremity of the lamellar topth-plate. 
The palleal impression extends from one muscular imprint to the other, rumning parallel with the margin of the base. There is a considerable difference observable in the width of the posterior part of the shell iu a series of specimens, which appears to be sexual; for a similar variation oceurs in the male and female shells of the recent species from the Ohio.

The collocation of these large mussels with drifted trees and bones of land reptiles, in clays and sands so manifestly of fluviatile origin, completes the analogy between the rafts imbedded in the delta of the Wealden, and those which float down, and become engulfed in the mud and silt of the Mississippi.

Fossil Cyprides. - The minute crustaceous animals termed Cyprides, of which the shells or cases of several species are so abundant in the Wealden strata, were brought under the notice of the reader in our examination of the tertiary strata at Whitecliff Bay and Headon Hill; and in the clays and shales of Sandown Bay (p. 136). These animals have the body enclosed in a horny case, consisting of two pieces united by a hinge line. 'They have one compound eye, and four feet, and two straight simple antennæe with a tuft of cilia at the extremities. They swim with rapidity, and may be seen actively pursuing the minuter animals on which they prey. Like other crustaceans, they frecuently shed their cases, and the surface of the 
306 GEOLOGY OF THE ISLE OF WIGHT.

mud spread over the bottom of still lakes is covered with their exuvia. 'The largest living Cypris, does not exceed one-sixth of an inch in length. In a fossil state these cases appear like minute, white, elliptical, or reniform scales, on the surfaces of the recently separated lamina of clay, shale, and limestone. After exposure to the weather the cases decompose, and leave the surface of the stone covered with their casts, which appear as minute polished tubercles; some layers of the compact ironstone have a granulated appearance from the abundance of these remains. 'Three species of the Wealden Cyprides are represented in lign. 25.

The immense accumnlation of the remains of these crustaceans in the Sussex marble is quite surprising; some slabs which I have examined under the microscope, have the shells and their interstices literally erammed with whole and broken cases. As the recent species imhabit either still lakes or gently flowing streans, and not the turbulent waters of estuaries, it follows that sediments largely charged with the exuvia of cyprides must have been deposited in lakes, or bays, or in tranquil streams, communicating with the flood of waters which transported to their present situation the bones of terrestrial animals and plants. 'These beds of fluviatile shells and cyprides, with scarcely 
any intermixture of other organic remains, which are spread over such wide areas of the Wealden formation, afford, therefore, decisive proof's of tranquil subsidence in freshwater.
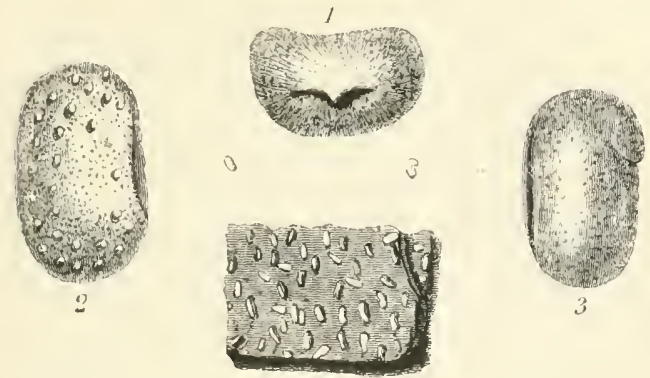

4

LIGN. 25 .

FOSSIL CYPRIDES; FROM BROOK BAY.

Fig. 1. Cypris spinigera; the small figure shows the natural size.

2. Cypris granulosa.

3. _._ Valdensis.

4. Clay, with numerous cases of the species represented fig. 1, of the natural size.

Fossil Fishes.-But few remains of fishes have been found in the Wealden of the Island; those which have come under my notice are some small teeth, and a fin-bone, of a specics of $H_{y}$ bodus (see p. 233); and several teeth and scales of the Lepidotus, a genus of extinct freshwater fishes, with very thick, enamelled, rhomboidal scales, and obtuse hemispherical teeth; the latter 
are called fishes' eyes by the peasints who collect fossils from these shores.* Detached scales and tecth of two species of Lepidotus occur in most localities of the Wealden deposits. $\dagger$ I found a portion of an intemaxillary bone with several teeth, and a group of ten scales of the Lepidotus Fittoni, in the cliff to the east of Brook Chine.

* Figures of the scales ant teeth of one species of Lepidotus of the Wealden are given in Medals of Creation, p. 438, Pl. Vl. fig. 10.

$+1 \mathrm{t}$ is rare to meet with any considerable number of scales in contact; but a few specimens were discovered in Tilgate Forest, exhibiting part of the cranium, the opercula of the gills, the pectoral and dorsal fins, and large masses of scales. These are now in the British Museum, in the room appropriated to Fossil Fishes. 


\section{CHAP'TER XI.}

FOSSIL BONES OF REPTILES-TIE IGUANODUN-HYL®OSAURUS-MEGALOSAURUS - CETIOSAURUS - STREPTOSPONTYLUS - PLESIOSAURUSTURTLES-IMPRINTS ON SANUSTONL-RIPPLE-MARKS-SUMMARYTHE COUNTRY OF THE IGUANODON-YOYAGE ROUND TIE ISLE OF WIGHT.

Fossil boNes of Reftiles. - The occurrence of bones and teeth of gigantic terrestrial reptiles in the beds beneath the chalk of the south-east of England, was first announced in the "Fossils of the South Downs," in which many remains of oviparous quadrupeds from the strata of Tilgate Forest are described. Relics of this kind have subsequently been discovered in numerous localities of the Wealden, and nowhere more abundantly than in the Isle of Wight; although search for these highly interesting remains has not hitherto been very actively or judiciously pursued.

The bones are washed out of the clifis by the iuroads of the sea, and strewn on the shore, where they become exposed to the action of the waves, and are soon abraded and deprived of any processes, or other anatomical characters, they may 
have retained after their original exposure to attrition, in the river by which they were transported and imbedded in the strata. Thus those parts which would afford the most valuable information to the anatomist become entirely defaced, and the specimens are for the most part waterworn masses of bone, indicating only the enormous magnitude of the animals to which they belonged. The bones even when imbedded in the sandstone and sand, are in general abraded, from having been transported by water from a considerable distance; those in the clays are commonly less injured, from the plastic material with which they were enveloped having, apparently, afforded some protection. The bones are coloured and strongly impregnated with iron; especially those in Brook Bay, which are permeated throughout with pyrites; groups of brilliant erystals of this mineral often invest the outer surface. 'The medullary cavities are occasionally found lined with white calcareous spar, and the cancellated structure of the bone is often filled with this substance. *

'The quantity of bones collected from the scashore in Sandown, Brixton, Brook, and Compton

* Some of these osseous boulders and pebbles afford interesting sections for the microseope. Sliees from speeimens presented to me by the liev. ('harles Pritehard, of ('lapham Common, beautifully display the cancellated structure of the bone, with the cells lined with pyrites and calcareous spar. 
Bays, during the last few years, is very considerable; the examples which $I$ have seen at various times, and in the possession of different persons, must have belonged to between 150 and 200 indivicluals. And though from their abraded and mutilated condition, but few of the specimens were instructive, yet so large a number proves that the country from which the Wealden deposits were derived, must have teemed with colossal oviparous quadrupeds. Some of the rolled bones indicate more gigantic animals than even the largest from Tilgate Forest, and now in the British Museum.

The Rev. Gerard Smith, in 1825, obtained several fragments of bones of reptiles from Sandown Bay; and in 1829 a considerable number was found by Mr. James Vine, near Bull-face Lerlge; the latter are now in the collection of the Geological Society of London. In 1834 Mr. John Smith, of Yarerland Farm, collected several large vertebræ of the Iguanodon, portions of two thigh bones, and many fragments of smaller bones: these relics were presented to the Oxford Museum.*

It must be borne in mind that these fossils have, for the most part, been picked up by persons

* See a Mlemoir, by the Rev. Dr. Buckland, on "Bones of the Iguanodon from the Isle of Wight," Geol. 'I'rans, vol. iii. New Series. 
wholly uninstructed as to the characters which alone render such specimens interesting. What the waves cast up on the strand, the fishermen gather together, tlıe casual visitor selects such as please his fancy, and the remainder are thrown away, or employed to pare the footpath, or surround the flower-border, of the cottager's dwelling.**

The remains hitherto found, are separate bones belonging to the well-known Wealden reptiles, viz. the Iguanodon, Hylaosaurus, Megalosaurus, and Streptospondylus; and the Cetiosaurus, Plesiosaurus, $\lceil$ and two or more kinds of turtles. I have seen but two teeth; a fragment of one belonging to the Megalosaurus, and the specimen figured in lign. 27 .

The Iguarodon. - Of this most gigantic of terrestrial reptiles, which, when living, must have more nearly resembled in its magnitude and huge proportions, the largest of our living pachydermata, than any of the saurian order to which it belongs, many vertebra, portions of ribs, and bones of the extremities, have been discovered in

* The largest toe-bone of the Iguanodon now in my possession was ohtained from a row of stones placed round the flower-plot of a cottage near Brixton. I much regret that my professional engagements have rendered it impossible for me to attempt to remedy the evil mentioned in the text.

+ llaring given a concise exposition of the osteological characters of these extraordinary beings in the "Medals of Creation" (vol. ii. p. 684, ch, xvii. and xviii.), witl full instructions for the collection of their remains; to that Work I beg to refer the reader desirous of pursuing these inquiries. 
the Wealden at Sandown Bay, and at Brook and Brixton. The vertebra are invariably deprived of their processes; even the neural arch is in general destroyed, and the waterworn body, or centrum of the bone, alone remains.* The specimens are commonly permeated with pyrites, and, in consequence, are of great weight. The long bones of the limbs are for the most part mutilated, and but seldom have an articulating extremity so perfect as to indicate the individual bone. Some of the fragments, however, retain characters sufficiently recognizable, and have unquestionably belonged to reptiles of enormous size. I obtained from Sandown Bay the lower half of a tibia (large bone of the leg), having the extremity that articulates with the foot perfect; the circumference of this bone is four times that of a perfect tibia of a young Iguanodon, which is one foot long: when entire, its length must therefore have been nearly four feet. The corresponding thigh-bone, estimated from the relative proportions of a femur and tibia in juxtaposition, would be a foot longer: the entire length of the leg and thigh to which the Sandown fossil belonged, must consequently have been upwards of nine feet.

* As shown in lign. 138, fig. 8, p. 697, "Medals of Creation," vol.ii. The perfect form of a caudal vertebra of the Iguanodon is represented in fig. 3 of the same lignograph. 
The most perfect femur, or thigh-bone, collected in the Isle of Wight, was dug out piecemeal from a fallen mass of the cliff in Brook Bay: it evidently belonged to an aged individual, and though squeezed and somewhat distorted by pressure while softened by long immersion in the clay in which it was imbedded, well displays the peculiar characters of this part of the skeleton of the Ignanodon. It is 3 feet 4 inches in length. The figure in lign. 26 is a representation of this specimen, as it would appear if uncompressed. The femur of the Iguanodon is so remarkable, that even fragments may readily be distinguished; and as portions of this bone are not unfrequently to be met with in the clay cliffs or on the shore, I subjoin the following description.

The head is hemispherical, and projects inwards; a laterally flattened process, or trochanter (lign. 26, a), forms the external boundary of the neck of the bone, from which it is separated by a deep and very narrow vertical fissure. 'The shaft is sub-quadrangular; a slightly elevated ridge, produced by the union of two broad, flat, longitudinal surfaces, extends down the middle of the anterior face, and diverging towards the inner condyle, gradually disappears. The shaft terminates below in two large rounded, and laterally 


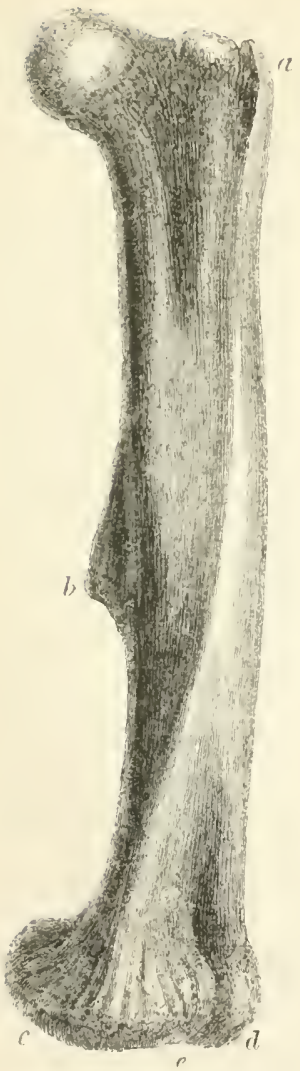

IIFX. 26.- LEFT FEMER OF AN IgUavodow. From Prook Bay. (The original, 40 inches in lenglh.) $a$, Upper trochanter.

h. Midd e trochanter.

$r$, Inner, $d$, outer condyle.

Groove between the condyles. compressed condyles $(r, d)$, which are separated in front and behind by a deep groove $(e)$. Near the middle of the shaft, the mesial, or inner edge, forms a compressed ridge, which extends into an angular projection, or inner trochanter (b). Thus the upper part of the femur may be known by the presence of the upper trochanter $(a)$; and if that process is broken away, the fractured surface indicating its position will be detected. If a fragment of the middle part of the shaft only is found, the flattened angular spaces, and the submedian trochanter (b), or the mark of its attachment, will identify it. The lower extremity of the femur may be distinguished by 
the deep groove (e) between the condyles, both in front and behind. The long bones of the Iguanodon have a large medullary cavity. *

Several bones of the feet and toes have been found in this locality. Dr. Buckland obtained a toe-bone of enormous size from Sandown Bay; it is six inches long and fifteen inches in circumference, at the largest extremity. $\uparrow$ The metatarsal and phalangeal bones of the Iguanodon are short and thick, and so much resemble those of the Hippopotamus, that Baron Cuvier at first supposed the specimens from Tilgate Forest belonged to that animal.

Tooth of the Iguanodon.- With the thigh-bone above described were found several dorsal and caudal vertebræ, many fragments of ribs, and the only tooth of the Iguanodon I have obtained from the Island. It evidently, like the femur, belonged to an adult, and very probaloly to the same individual. The crown is worn down almost to the neck of the tooth, and shows the remarkable character imparted to the teeth of this herbivorous reptile, by the trituration of its food,- - character in which they differ from the teeth of any other known reptile, either living or extinct; for all 
other herbivorous reptiles chip off and swallow their food whole, the construction of their jaws not admitting of a grinding motion.* From this condition of the crown, as shown in the tooth figured below, it is obvious that the Iguanodon fed on regetables, and masticated its food like the

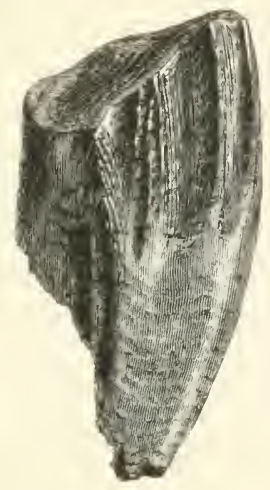

LIGN. 27 .

TOOTH OF AN IGUANODON.

From the Wealden, Brook Bay.

horse and other herbivorous mammalia: while the base shows the imprint of the sucressional tooth, which, by its pressure, occasioned the absorption of the fang of the old one. In the perfect tooth, the crown is of a prismatic form,

* For an account of the development of the teeth of the Iguanodon, see "Fossils of Tilgate Forest," p. 72; and "Wonders of Cieology," p. 390. 
with. three or four longitudinal ridges down the front, and a broad denticulated margin on each side.* The resemblance between the unworn teeth of the Iguanodon and those of the Iguana, a herbivorous lizard of the West Indies, suggested the name of this colossal extinct reptile; but the teeth of the Iguana are very small, not exceeding in size those of the mouse.

Sections of the teeth are beautiful objects under the microscope, and show that the structure of the dentine, or tooth-ivory, is coarser than in other reptiles, and resembles that which characterises the teeth of the Sloth tribe. The crown of the tooth is incrusted with an external coating of enamel, which is thick in front, and thin on the inner surface. In consequence of this disposition, and of the dentine being hardest in the anterior part, the grinding surface of the tooth is always worn away obliquely, and a sharp cutting front edge of enamel maintained in every stage. $\uparrow$

Sacrum of the Iguanodon.-A very remarkable peculiarity in the anatomical structure of the Iguanodon, and of the Hylieosanrus and Megalosaurns, consists in the sacrum being composed of five vertebra anchylosed, or fixed together, into a solid 
column; whereas in all living saurians the sacrum consists of but two vertebrx. The neural arches of the vertebræ are shifted to the interspaces between the bodies of those bones, by which more solidity is given to the pelvic arch. Professor Owen (who first pointed out these modifications of structure) states, that the sacrum of the Ostrich presents the same characters, and in the young bird the individual vertebræ, and the remarkable change in the relative position of the vertebral elements, may be clearly traced.

Though these details are of the greatest interest to the comparative anatomist, I should not have dwelt upon them in the present work, were it not probable that specimens of this part of the skeleton will come under the notice of the visitor, and would, perhaps, from their unsightliness, be rejected. I have obtained from Brook Bay several waterworn portions of the sacrum, consisting of two or three anchylosed vertebræ; the finest example of the entire series belonging to a large individual, was found on this coast.**

Form of the Iguanodon.-From the numerous detached bones that have been collected from

* This fossil is in the interesting museum of $\$$. D. Saull, Esq., of 15, Aldersgate Street, City, to which visitors are, with great liberality, admitted every Thursday at 12. Mr. Saull's collection of organic remains contains many specimens from the Isle of Wight. 
various localities of the Wealden, and with the aid of the few specimens in which several are collocated in the same block of stone, the size and proportions of the body and limbs of the Iguanodon may be determined; yet but a vague idea of the form and appearance of the original animal can be derived from the relies hitherto discovered. For the great diserepancy between the known parts of the skeleton, and the corresponding bones in the largest existing saurians, renders it vain to attempt the restoration of the form of this colossal reptile, till the skull, jaws, \&e. are known. In all probability the entire or a considerable portion of the skeleton of a young Iguanodon, will sooner or later be brought to light, and yield the information necessary to enable the palæontologist to reconstruet the skeleton, and delineate the form of the living original.

In the present state of our knowledge we may, however, safely conclude, that the body of the Iguanodon was equal in magnitude to that of the elephant, and as massive in its proportions; for being a vegetable feeder, a large development of the abdominal region may be inferred. Its limbs must have been of a proportionate size to sustain so cnormous a bulk; one of the thigh-bones (in the British Muscum) if covered with muscles and 
integuments of suitable proportions, would form a limb seven feet in circumference. The hinder extremities, in all probability, presented the unwieldy contour of those of the hippopotamus or rhinoceros, and were supported by a very strong short foot, the toes of which were armed with claws like those of certain turtles.* The forelegs appear to have been less bulky, and furnished with hooked claws resembling the ungueal phalanges of the Iguana. The teeth demonstrate the nature of the food required for the support of this herbivorous reptile, and the power of mastication it enjoyed. The palms, ferns, cycadeous plants, and coniferous trees, with which its remains are associated, indicate the flora adapted for its sustenance. But the physiognomy of this creature, from the form of the skull and jaws, constructed as the latter must have been to give support to the powerful muscles necessary for the trituration of tough vegetable substances, must have remarkably differed from that of all known saurians.

The length of the Iguanodon has been variously estimated, the difference in the computation depending chiefly on the length assigned to the tail, which in the Iguana and many other lizards is 
much longer than the body. If the tail of the fossil reptile was slender, and of the same relative proportions as in the Iguana, the largest individual would be fifty or sixty feet long; but it is more probable, and in fact almost certain from the shortness of the bodies of the caudal vertebræ, that the tail was short, and flattened in a rertical direction, as in certain living reptiles-for example, the Doryphorus; the length, therefore, would be reduced to little more than thirty feet.*

From what has been advanced we may conclude, that the Iguanodon was a gigantic but inoffensive herbivorous reptile, which lived on the ferms, cycadex, palms, and coniferæ that constituted the flora of the country of which it appears to have been the principal inhabitant.

Hyleosaurus, or Wealden Lizard.-This is another reptile of the Wealden, possessing the same remarkable conformation of the sacrum as the Iguanodon. It is distinguished by a peculiar modification of the bones composing the sternal arch, and by its osseous dermal appendages: like the bones of the former reptile, its remains were first observed in the strata of 'Tilgate Forest.

The scapula is like that of the crocodiles, while the coracoid bone is of the lacertian type. The ribs 
have the bilobed head, as in the crocodiles, associated with the arched and rounded process of the lizards, and an enormous expansion of the bone at its spinal curvature. This reptile possessed a very formidable dermal covering: it had rows of elliptical and circular dermal bones along each side of the vertebral column, and appears to have been armed with a series of angular spines of great size, arranged along the middle of the back; in the same manner as the dorsal fringe of the Iguana. The? structure of the bone composing these dermal processes, closely resembles that of the ligamentous fibres of the corium, or skin, and seems to have resulted from an ossified condition of the dermal integument. A few detached vertebræ of the Hylæosaurus, recognisable by their perfectly circular and nearly flat extremities, have been found in the Weald clay at Brixton.*

Megalosaurus. $\nmid$-This name was given by Dr. Buckland to an enormous reptile, of which teetl and bones were first observed in the oolitic limestone of Stonesfield, near Oxford, and afterwards in the Wealden strata. The teeth present a striking contrast to those of the Iguanodon; they

* See "Medals of Creation," p. 734, and "Memoirs on the Fossil Reptiles discovered in Tilgate Forest," Philos. Trans. Part 11. for the year 1841.

$\dagger$ See Dr. Buckland's Bridgewater Essay. 
are sabre-shaped, with trenchant serrated edges. The original was probably carnivorous, and nearly thirty feet in length. As it was contemporary with the Iguanodon and several other large saurians, it may have preyed on their young and on the lesser reptiles. Many teeth, vertebra, and portions of the femur of this animal, have been found in the Island. The vertebræ are not subquadrangular like those of the Iguanodon, but are cylindrical at the ends and contracted in the middle, and have a very smooth surface. The femur is nearly cylindrical and slightly bowed; it has two large rounded prominences, or trochanters of nearly equal size, below the head of the bone; it may therefore easily be distinguished from the thigh-bone of the Iguanodon.

Centosaunus. - This extinct reptile, as its name imports, bore some resemblance to the Cetaceans. The vertebrix are almost circular at the ends, and have a very short body; the front articulating surface is nearly flat, and the other concave, in the dorsal vertebra, but in the caudal both ends are deeply hollowed; they are very large, often eight inches in diameter. By these characters the vetebra of the Cetiosaurus may easily be recognised. I have obtained several from the weald clay at Sandown and Brook. The original 
animals are supposed to have been of aquatic, and probably of marine, habits, on the evidence of the sub-biconcave structure of the vertebrre, and of the coarse cancellous tissue of the long bones, which are destitute of a medullary eavity. They must have rivalled the whales in bulk, for some remains indicate a length of forty or fifty feet.*

Streptospondylus. - Among the large vertebræ washed up on the shore in Brixton Bay, I found several with one end convex and the other concave; these belong to the extinct crocodilian reptile called Streptospondylus (meaning reversedspine), because these vertebræ are arranged in the spinal column in a position the reverse of that which obtains in all other reptiles of the same osteological type; for the convexity or ball of the vertebræ is placed anteriorly, whereas in the crocodile, \&c. it is in the opposite direction. The original, in its form and habits, probably bore a general relation to the crocodiles.

Plesiosaurus.-The splendid collection in the British Museum, which contains several perfect skeletons of different species of this genus of extinct marine reptiles, must be too well known to render any description necessary of the osteological

* Medals of Creation, vol. ii. p. 726 .

† Cuvier's Recherches sur les Ossemens Fossiles. Tom. V. pl. 6. 
characters of the Plesiosauri and Ichthyosauri. A few vertebræe of Plesiosauri are the only remains of these animals I have obtained from the Island.

Fossil Turtaes.-Of chelonian reptiles, waterworn fragments of bones are the only vestiges that have come under my notice. Some of these fragments in all probability belong to the Trionyx Bakerelli, a species which occurs in the Wealden strata of Tilgate Forest, ${ }^{*}$ and is characterised by the granulated surface of the costal plates, and a dermal covering of tortoise-shell, as is shown by the imprints of the scales left on the bones. Except in possessing a defensive integument of this kind, this extinct chelonian must have resembled the existing predaceous soft turtles; and doubtless like them inhabited the mud-banks of rivers, and preyed upon the eggs and young of the larger reptiles, and on the uniones and other mollusca, the shells of which are often found associated with its remains.

Imprints on SANDSTONE.- We must here conclude our description of the fossils that have been discovered in the Wealden strata of the Isle of Wight; to attempt a full exposition of the characters and relations of these organic remains,

\footnotetext{
4 Geology of the S. E. of England, p. 255. Medals of Creation, p. 778.
} 
would require a volume expressly devoted to the subject. A few additional remarks are, however, necessary on some anomalous appearances in the sandstone of Brixton Bay, that have recently come under my notice. The occurrence of imprints resembling the foot-tracks of birds and reptiles, on the surface of slabs of sandstone of very ancient formations, must be known to the well-informed reader, from the lucid illustration of the subject, in Dr. Buckland's Bridgewater Essay. Among those supposed foot-prints are several of large dimensions, described under the name of Chirotherium, which are conjectured to have been made by some enormons three-toed reptile, passing over the stone when it was in a soft state. Others equally colossal, from the arrangement of the markings on the slabs indicating the progressive footsteps of bipeds, have been ascribed to gigantic extinct birds. * The layer of clay, or sandstone, overlying these imprints, generally retains casts of them, which appear in relief on the surface of the slabs when removed; in other instances the cast of a single mould alone remains, and being more consolidated than the matrix, is often extracted whole. Several large sandstone casts of this kind were dis- 
covered last year in the Wealden sands at Hastings, and sent up to the Geological Society. A similar cast has been obtained from the Wealden sand in the cliff in Brixton Bay, and is in my possession. This specimen is a solid tripartite mass of fawn-coloured sandstone; the middle process is fifteen inches, and the two lateral projections are twelve inches in length; the greatest thickness is six inches; the processes are laterally compressed and rounded at the extremities, and united to one common base. As the origin of these singular concretions is very problematical, every specimen should be preserved; and if several occur on the same bed of sand, their relative position should be carefully ascertained.**

Ancient Rippla-Marks.-Connected with this subject are the ripple-marks so often pervading extensive surfaces of sands, sandstones, and clays, in sedimentary deposits that have been formed on sea-shores, or along the banks of rivers, or in

* The metlod adopted to obtain impressions from engraved monumental brasses, namely, the placing of tough thin paper over the surface of the inscription or efligies, and rubbing it freely with the blaek composition termed "heel-ball," which adheres to the parts in relief, but leaves the cavities white, will be found convenicnt for olstaining an accurate plan and outline of the imprints on the sandstone. This process is also applicable to any fossil that has a surface flat and firm enough to bear the friction when covered by the paper. I lave often taken in a few minutes, imprints of the plates of turtles, scales of fishes, \&c. sufficiently distinct to exhibit the general characters of the surface of the specimens. 
bays, deltas, lakes, and estuaries, in comparatively shallow water. In many parts of the Wealden formation these appearances are very striking; especially in the vicinity of Horsham,* and in the quarries in Tilgate Forest in Sussex. $\dagger$ The slabs of limestone, clay, and sandstone, exposed in recent falls of the cliffs along the southern shores of the Island, are frequently covered with ripplemarks.

Every one must have noticed when walking by the side of a river at low water, or on the sands of the seashore, that if the water has been agitated by the wind, the surface of the mud or sand is furrowed more or less deeply by the rippling of the waves; the markings presenting various appearances according to the force and direction of the wind and currents. The undulations on the surface of the sandstone have arisen from similar operations. In many instances the stone is so rough as to be employed in stable-yards, where an uneven surface is required to prevent horses from slipping as they pass over. Sometimes the fur-

* These were first noticed by Mr. Lyell in 1822, and described in a letter addressed to the author.

+ It is singular that although Professor Playfair mentions the cause of this appearance as undoubted, yet so little attention or credit was given to the statement, that my description of the phenomenon was received with much hesitation. 
rows are deep, denoting that the water was mueh agitated, and the ripple strong; in other instances the undulations are shallow, and intersected by eross-ripples, indicating a change in the direction of the waves. Some slabs are covered by slightly elevated, broad ridges of sand, made up of gentle risings disposed in a erescent shape; these have been produced by rills flowing into the river, during the recession of the ticle. The rippled surfaces often bear traces of the trails of mollusca, and annelides, and in some strata, imprints of the claws of crustaceans, of the pectoral fins of eertain fishes, and of feet of reptiles have been observed.* But I have never deteeted unequivocal evidence of footmarks of any kind in the Wealden strata. Impressions of regretables, several of which appear to have been produced by grasses, were abundant on some recently exposed slabs near Brook Point, on my late visit; the vegetable matter had evidently been changed to carbon, which was in a great measure washed away, but enough remained to point out the origin of the markings. I have observed similar appearances on slabs of sandstones and clays lying on the embankments of the recently constructed Tombridge Wells Railway. 
Sumany.-And now, ere we depart from these shores, and bid farewell to seenes so fraught with interest and instruction, I would detain the reader a brief space, and while the data are before us, endeavour to interpret the nature of those physical revolutions of which they afford such unequivocal evidence. It appears, indeed, scarcely possible for the most incurious observer while sitting on these rocks of petrified trees, and surrounded by fossil bones of enormous reptiles, and heaps of river-shells obtained from the neighbouring cliffs, not to speculate on the causes which have given rise to these extraordinary results. For as a profound thinker has justly remarked, "when any natural phenomena are for the first time observed, a tendency immediately develops itself in the mind to refer them to something previonsly known, and bring them within the range of acknowledged sequences." "*

It was with a view of inducing a train of thought which should lead the intelligent stranger, unfamiliar with the nature of geological evidence, to attempt the interpretation of the appearances presented to his notice, that this excursion was introduced by some general remarks on the changes

* "On the Currelation of Physical Forces;" by W. R. Grove, Esq. M.A. F.R.S. \&. London, 1846. 
effected on the surface of the land, by the agency of streams and rivers.

Let us test the facts before us by the principles enumciated in those remarks. We have here strata of great thickness, made up of laninated detritus, identical in appearance and composition with the consolidated mud-banks of rivers and deltas-we have rafts of drifted pine-trees, and the remains of cycadeous plants, and arborescent fernsinnumerable layers of freshwater shells and crustaceans, with large mussels resembling the unionidæe of the rivers of America-heaps of waterworn bones of colossal oviparous quadrupeds, which comparative anatomy instructs us belong to types of organization long since extinct-in fine, an accumulation of transported materials teeming with the spoils of some unknown region, associated with fluviatile mollusks and crustaceans, without any intermixture of marine exurix. What is the obvious inference-what the unavoidable conclusion at which we must arrive? Unquestionably, that these deposits were the delta of a river, which flowed through a comntry possessing a fauma and flora of a tropical character, and essentially distinct from any now known to exist.

Time countix of the IgunNodon.--We have here then data from which, by the method of 
induction previously explained, we may restore, as it were, the region whence the Wealden strata were derived, the animals by which it was inhabited, and the vegetables that clothed its surface. Whether that country was an island or a continent cannot, perhaps, be determined; but that it was diversified by hills and valleys, and irrigated by streams and rivers, and enjoyed a climate of a higher temperature than any part of modern Europe, is most evident. Arborescent ferns, palms, coniferous trees, and cycadeous plants, constituted its groves and forests, and delicate ferns the vegetable clothing of its soil; and in its fens and marshes the equiseta, and plants of a like nature, prevailed. Its principal herbivorous quadruped was the enormous lizard, the Iguanodon; its carnivora, the Megalusaurus and other predaceous reptiles; crocodiles and turtles frequented its rivers, and deposited their eggs on the banks and shoals; and its waters teemed with fishes, mollusca and crustaceans. That the soil was of a sandy nature on the hills and plains, and argillaceous in the lowlands and marshes, may be inferred from the vegetable remains, and the lithological character of the strata in which they are 'imbedded. Some inferences relating to the prevailing atmospheric condition of the country may 
also be drawn, from the mudulated surfaces of the sandstones, and from the fossil trees. In the former we have proof, that when the land of reptiles existed, the water was rippled by the breezes, which then, as now, varied in intensity and direction in a brief space of time; by the latter, that in certain situations the wind blew from a particular quarter for a great part of the year, and that the mean annual temperature was as variable as in modern times. From what has been advanced, it must not, however, be supposed, that the comtry of the Iguanodon occupied the site of the south-east of England; and that the animals and terrestrial plants of the Wealden, lived and died near the spot where their relies are cutombed. For with the exception of the shells and crustaceans, which probably inhabited the delta, all the fossil remains bear marks of having been transported from a great distance. But though three-fourths of the bones we discover have been broken and rolled,--the teeth detached from their sockets,-the vertebra and bones of the extremities, with but very few exceptions, disjointed, and scattered here and there, -the stems and branches of the trees torn to picees, and deprived of their foliage-there is $110^{\circ}$ intermixture of sea-shells, nor of beach or shingle; 
these remains have been subjected to abrasion from river currents, but not to attrition from the waves of the ocean. The gigantic limbs of the large reptiles could not have been dissevered from their sockets without great violence, except by the decomposition of their tendons from long maceration in water; and if the latter had been the sole cause, we should not find the bones broken and separated, but lying more or less in juxtaposition, like the skeletons of the Plesiosauri in the Lias. The condition in which these fossils occur, proves that they were floated down the river with the rafts of trees, and other spoils of the land, till, arrested in their progress, they sank down, and became imbedded. The phenomena here contemplated cannot, I conceive, be satisfactorily explained upon any other grounds; and the source of the mighty stream which flowed through the country of the Iguanodon, must therefore, like that of the Mississippi, have been hundreds, perhaps thousands, of miles clistant, from the delta accumulated in the course of ages at its mouth.

Voyage round tife Isle of Wight. - As during the summer months, excursions round the Island are almost daily made by the steamers, an opportunity is afforded of obtaining a general view of the geology of the coast in the course of a few 
hours. To a person acquainted with the physical structure of the country, such a voyage is alike agreeable and instructive, and the reader will find a day well spent in taking a rapid survey of the most important geological sections which the coast scenery exhibits. The steamers leave Cowes or Ryde, and take an easterly or westerly course, according to the state of the tide. In the following brief notice, the localities most worthy of remark, in a geological point of view, are described in the order they will appear, if the former route be pursued.

Proceeding from Ryde to the eastward, we coast along the northern shore of the Island, which is almost everywhere covered with vegetation to the water's edge; a low bank, or cliff, of the freshwater eocene marls and limestones, being the only indication of its geological structure. St. Clare, the charming seat of Col. Vermon Harcourt, stands on an eminence of these deposits. Doubling the eastern point of St. Helen's, Bembridge Foreland appears, surmounted by the range of chalk hills that terminates at Culver Cliff. We cross the mouth of Brading Haven; the little town of Brading is seen nestling in a grove of elms at the foot of the chalk downs, which form the western boundary of the view. The upper horizontal 
离

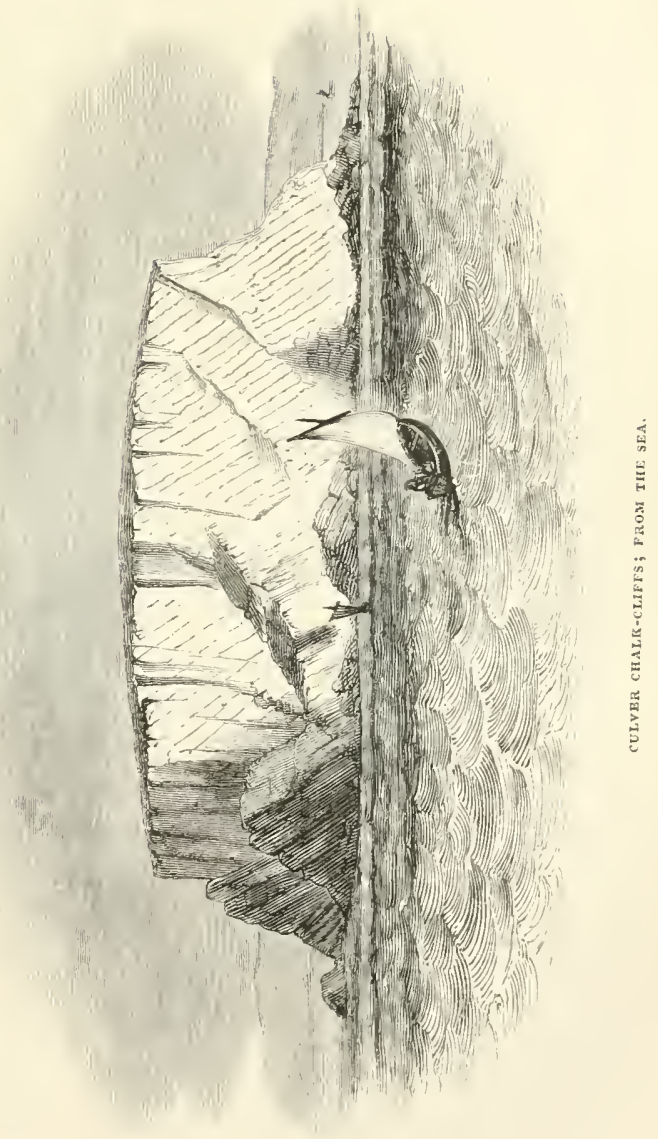



freshwater strata on the northem extremity of Whitecliff Bay (see p. 12\%) next appear, and a good view is soon obtained of the bay, bounded on the south by the magnificent chalk cliffs of the Culvers.

On reaching the extremity of Whiteclifi Bay, the rertical section of the highly inclined chalk strata, which forms the eastern promontory of the Island, is finely displayed (see $P l$. XV.). The dip of the strata, varying from $50^{\circ}$ to $70^{\circ}$ towards the north, is clearly marked by the layers of flint nodules, which are distinguishable a quarter of a mile from the shore. Culver Cliffs, which the reader will remember, are the eastern termination of Bembridge Downs (see lign. 8, p. 126), are between 300 and 400 feet high, and abont a quarter of a mile in breadth. When off the promontory, a. very interesting geological view is obtained; at one glance we see the nearly rertical chalk, bounded on the right (north) by the eocene strata of Whitecliff, and on the left (south) by the greensand of Redcliff.

Upon doubling the headland, we enter Sandown Bay (see the section, lign. 9, p. 134); the lower chalk, firestone, galt, and greensand, appearing in succession, like sloping bands of yellowish white, green, blne, and deep red; the latter denoting the 
ferruginous sands of the lower group. Sandown Fort is now visible, and marks the low tract consisting of the Weald clay (p. 133). The new church and little town of Sandown, are seen on the brow of the sand cliffs which form the western side of the bay, and extend toward Shanklin, retaining the same dark red ferruginous colour as those at Redcliff. The eastem termination of the sonthern range of chalk, forming the lofty downs above Shanklin, next appears, and seaward, the bigh but subordinate cliff of greensand at Dumnose Point. The dip of the strata in the cliffs on each side of Sandown Bay, and the anticlinal axis formed by the elevation of the Wealden, may be distinguished by means of a good telescope.

Off Dumnose, we lose sight of the immer range of chalk downs, and gain the region of the Undercliff, which from the sea presents, in the foreground, a line of fallen masses of rock and strata scattered along the sea-shore; and above, a verdant terrace covered with trees and shrubs, with here and there houses peering out from anid the foliage-the barrier of firestone capped with chalk, surmounting the terrace on the north, and bounding the view for a distance of six miles (see p. 251). The ledges of cherty firestone projecting like lines of masonry along the face of 
this inland cliff, may be distinguished, if the steamer keeps within the usual distance of the shore.

Nearing Blackgang, St. Catherine's appears towering above the western termination of the Undercliff. The Sandrock hotel is seen standing on a lecke high up the precipitous escarpment of the greensand, which here forms the sea-cliff (see p. 234), near the foot of the inland cliff of firestone; the latter rises to within 200 feet of the summit, which is nearly 800 feet above the level of the sea. The ruins of the tower of St. Catherine surmount the whole. The white chalk is seen forming the top of the downs, and appearing from the sea as an inconsiderable layer, immediately over Blackgang.

From Blackgang to Atherfield the cliffs are entirely composed of the greensand, and the general direction of the beds from east to west may be easily traced (see lign. 17, p. 215). The clays and sands along this part of the coast present a very curious appearance. The lower strata are generally dark, indeed, ahnost black, but the uppermost are of a light ferruginous colour; and wherever springs are thrown out by the clay partings, the cliffs are stained with broad streams of ochreous yellow. This appearance is cor- 
rectly attributed by Sir Henry Englefield, to the action of the water that percolates from the surface of the soil through these strata, and issues out on the face of the cliff; the oxidation of the sands and clays is the result of the decomposition of the sulphuret into peroxide of iron. This change is often accompanied by the formation of erystals of sulphate of lime or selenite.* The abundance of nodules of pyrites in these clay cliffs, as well as in those of the Wealden, is so great, that considerable quantities of this mineral are collected on the shore by the cottagers, for sale to the copperas manufacturers.

Approaching Atherfield, the undulated outline of the distant horizon on the north, denotes the re-appearance of the central range of chalk downs, which we lost sight of behind Dumnose Point, and is here seen extending in a south-westerly direction towards the southern shore. The stationhouse on Atherfield Point marks the locality where the junction takes place between the Wealden and the greensand (p. 221 ).

The next interesting geological features of this coast, are the cliffs at Brook Point, but the steamers pass at so great a distance from

* A similar result has taken place in some of the railway clay embankments, and been productive of considerable injuy to the works. 
VOYAGE ROUNI) THE ISLE OF WIGHT.

the shore, that the general bearing of the strata only can be distinguished. In the long sweep exposed in these bays (p. 210), the greatly elongated arch, formed by the anticlinal axis of the Wealden (p. 214), may be distinctly made out in a clear state of the atmosphere. Shalcomb Down (p. 220), now forms the inland distance on the north; and as we near Compton Bay, the middle clialk range is seen extending to the shore, and the sea washes the base of the magnificent line of chalk hills from Afton Down to the Needles.

The position of the greensand, galt, and firestone, beneath the white chalk, in the cliffs west of Compton Chine, may be distinguished from a distance, owing to the contrast of colour presented by the upper and lower groups; as in Redcliff in Sandown Bay. Freshwater Bay (p. 195) is now gained, and the cliffs of the Mainbench, and of Scratchell's Bay, and the Needles, stand forth in all their sublimity (see p. 197). There is one point in Scratchell's Bay in which a magical effect is produced, by the sudden appearance of the richly coloured cliffs in Alum Bay, between the pure white pinnacles of chalk.

As we sail round the Needles, the distant Isle of Portland is seen on the western horizon, and on the north are the shores of Hampshire (p. 164). 
344 GEOLOGY OF THE ISLE OF WIGHT.

The vertical strata of Alum Bay (p. 146), and the freshwater series at Headon Hill (p. 151), are now on our right; and we perceive that the structure of this north-western extremity of the Island, is the counterpart of the north-eastern promontory at Culver Cliff and Whitecliff Bay, which we sailed by in the earlier part of our voyage. Colwell and Thorness Bays are next passed, and we land at Yarmouth to prepare for our excursion to the Dorsetshire coast. 


\section{CHAP'TER XII.}

GEOLOGICAL EXCURSIONS ALONG PART OF TIIE SOUTHERN COAST OF DORSETSHIRE.

YOYAGE FROM YARMOUTH TO SWANAGE-SWANAGE BAY-THE PURBECK STRATA-FOSSILS OF THE PURBECK STRATA-THE PORTLANDOOLITE - GEOGRAPHICAL DISTRIBUTION OF THE STRATA-THE SOUTH-EASTERN COAST OF PURBECE-THE SOUTH-WESTERN COAST -WORBARROW BAY-LULWORTH COVE-FOSSIL TREES-DURDLE COVE - CHALDON DOWNS - RINGSTEAD BAT-THE ISLE OF PORTLANDPETRIFIED PINE-FOREST-FOSSILS OF PORTLAND AND WEYMOUTHRETROSPECT-COROLLARY.

Voyage from Yarmouth to Swanage.-At the distance of about fifteen miles across the channel, from the western extremity of the Isle of Wight, the south-eastem part of the county of Dorsetshire forms a peninsula, which is called the Isle of Purbeck. This district is of an irregular oval form, its greatest length from east to west is between thirteen and fourteen miles, and its average breadth from north to south, seven miles. It is composed of cretaceous, wealden, and oolitic deposits, and a brief notice of its geology will form an interesting and highly instructive sequel, to our survey of the corresponding strata in the "beautiful Island." 
346 GEOLOGY OF TIE ISLE OF PURBECK.

It Yarmonth a cutter may be engaged to convey the visitor to Swanage, a little town on the castern coast, situated near the once celebrated quarries of Purbeck marble. But during a great part of the year, steam-packets ply twice or thrice weekly from Portsmouth and Southampton, to Poole, and Swanage, calling for passengers at Ryde, Cowes, and Yamouth; so that the Isle of Purbeck may be included in our geological excursions with but little inconvenience. 'This short voyage is very delightful in fine weather, for with a telescope the principal lines of strata may be traced along the distant coasts, and a comprehensive view obtained of the relations, and original continuity, of the now dissevered masses which form the dry land.

In sailing from Iarmouth towards the Isle of Purbeck, our course, after passing by the Needles, is to the west, and the chalk cliffs of Dorsetshire soon become distinctly visible; and we at once perceive, that if the vertical chalk range we are leaving behind were prolonged in a direct line to the west, it would unite with that towards which we are steering our little bark. Mr. Webster has graphically described the most striking features of the varied landscapes which successively appear in this voyage: "The Island we had just left assumed 
a very interesting appearance. The gradual rise of the northern side above the sea-the coloured strata of Alum Bay - those singular masses of rock the Needles-with the majestic chalk cliffs behind them of the most dazzling whiteness-and the precipitous face of the southern side of the Downs above Freshwater-composed altogether a picture of the most romantic character. On the north lay the coast of Hampshire (see p. 164), consisting of tertiary clay cliffs, above which were seen the town of Christchurch, and several lesser places. As we approached the Dorsetshire side, I perceived that the chalk cliffs were of great height, forming the eastem end of the promontory called Handfast Point; on the north side of which lay Studland Bay, and on the south Swanage Bay. In these cliffs, which present a vertical section of the Isle of Purbeck from north to south, were seen, while we were yet some miles distant, several very large caverns; and towards the north end four or five detached masses of rock rising out of the sea; these were evidently isolated portions of the chalk, which like the Needles had resisted longer than the rest of the cliff, the destroying effects of the waves. When sufficiently near, I made the vessel lay to, that I might examine the stratification by a telescope; and I was surprised and delighted to 
find the south end composed of strata of chalk and flint quite vertical." **

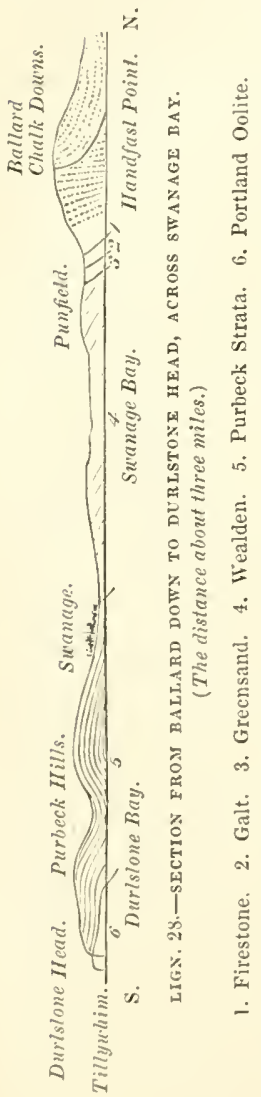

Sivanage Bay.-We land at the little town of Swanwich, or Swanage, where excellent accommodation may be obtained, and vehicles and boats hired for excursions by land or water. 'The exportation of stone is still so considerable as to give the place an aspect of cheerful activity.

The cliff's that extend across Swanage Bay, expose a transverse vertical section of the strata from north to south, and afford a key to the geological structure of the Island; as shown in lign. $2 \mathrm{~S}$.

In this line of coast, the entire series of deposits from the Chalk at Ballard Douns, to the Portland oolite at Durlstone Head, is displayed in the natural order of succession. This section will remind 
the reader of that from Shalcomb to Brook Point (lign. 1S, p. 220); but in the latter, only the upper wealden beds appear on the south, the lower group not being exposed to view.

The general dip of the strata is to the north, but the angle of inclination is not uniform, and some of the cretaceous and wealden deposits present flexures and contortions of a very remarkable character. Before we stroll along the shore to collect specimens, and cxamine the strata in detail, it is desirable to enigage a boat, and sail across the bay, that we may obtain a general idea of the geological structure of the country. From Swanage the cape or headland of Handfast Point, a chalk cliff 350 feet high, appears on the north; and to this spot we will direct our course. Doubling this promontory we enter Studland Bay, and perceive that the coast is formed of the upper chalk, which emerges from beneath the eocene strata on the north at a very low angle, and continues round the extreme point of the cape, where several pimacles, that may be regarded as representative of the Needles, guard the coast. A little to the south of this point, the layers of chalk and flint, which are as strongly defined as in Culver Cliff ( $p .336)$,

* If the section, Lign. 28, were prolonged, Studland Bay would appear on the north of Ballard Downs. 
suddenly turn upwards in a curve, forming nearly a quarter of a circle, and abut against vertical strata of the same kind; "the vertical layers of flints meeting the bent part of the chalk, as so many ordinates would meet a curve, and decreasing in height as they get more under it."* (See lign. 28. Handfast Point). This appearance, as Mr. Conybeare has clearly shown, is attributable to a fault or dislocation, which in part of its course coincides with the lines of stratification. The chalk in the curved and vertical strata is extremely indurated, but in the horizontal, is of its usual consistence. The vertical flints, like those in the Isle of Wight, are, for the most part, shattered (ante, p. 202), and the fragments separated from each other by the chalk. These flints do not fall to pieces in the hand, like those of Freshwater, Culver, \&c. because the severed portions are firmly held together by the chalk in which they are imbedded; but there is the same variety in the size and form of the fragments, from large angular pieces to fine powder. $\uparrow$

* Geology of England and Wales, p. 110.

+ These appearances were first pointed out by Mr. Webster, whose descriptions will be found as faithful as they are lucid, by those who visit the scenes he has so exquisitively portrayed in the beautiful illustrations of Sir Henry Finglefield's work. These phenomena may be most easily examined on the south side of the eliff at Ilandfast Point, where the shore is generally strewn with litge masses of fillen clialk. 
Southward of Handfast Point, near the foot of Ballard Down, there is a small cove or recess termed Punfield, in which strata of Firestone, Galt, Greensand and Wealden clay, are seen in a highly inclined position. The middle series of the Wealden deposits, the Mastings Sands, which are not visible in the Isle of Wight, form the line of cliffs from Punfield to Swanage. These beds consist of sands, clays, and calcareous grits, enclosing seams and disseminated masses of lignite, and containing bones of reptiles, \&c. The sea-shore, as in Brook and Sandown Bays, is often strewn with fossil trees, and rolled bones of the Iguanodon and other animals, that have been washed out of fallen masses of the strata. The tract on which the town of Swanage stands, is on the line of junction between the Hastings beds, and the Purbeck group; the latter comprises clays, sands, and limestones, with bands of shelly marbles, calcareous shales, and coarse limestones, full of small paludince, cyclades, and other freshwater shells.

The spaces respectively occupied by these deposits as measured along the foot of the cliff, are given by Dr. Fitton as follow :-

Firestone . . . . . . . . . 250 paces.

Galt . . . . . . . . . 200 - 


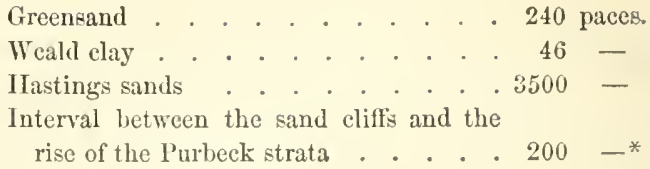

The cliffs in Durlstone Bay are entirely composed of the Purbeck strata; those in the middle are much bent and undulated, but in the southern part, the arrangement of the beds is well displayed. The termination of this coast at Durlstone Head, consists of the marine strata ealled the Portland oolite, which are seen to emerge from beneath the Purbeck hills (see lign. 28).

In the coast section thus briefly described we have, therefore, the following series:-

I. The Cretaceous System, comprising the upper and lower white chalk, firestone, galt, and greensand.

II. The Wealden, including the Weald clays, the Hastings beds, and the Purbeck.

III. The Oolite, of which the upper, or Portland group, is alone visible.

Of these, the Purbeck and Portland strata are for the first time brought under the observation of the reader, and will therefore require more particular notice.

- Geological Transactions, vol. iv. p. 207. 
Tine Purbeck strata.-The ippermost P'urbeck bed is a green, calcareons, and for the most part friable, deposit, containing shells of a small species of Unio; beneath this is a stratum of the well-known marble, composed of an aggregation of the small river snail-shells already described (Paludina elongata, Pl.VI. fig. 2); a polished slice of this marble is figured in lign. 29. Some of

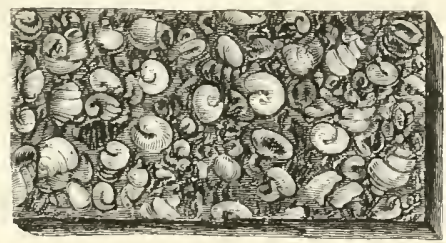

I.I GN. 29 .

POLISHED SLAB OF PURBECK MARLLE.

(Composed of petrified river snail-shells.)

the layers contain interspersions of the large paludina (P. fuviorum, Pl. VI. fig. 3) of the Sussex marble, and also a few small river-mussels. I have seen polished slabs of this kind, in which sections of bivalves (Uniones) formed the principal markings; these shells were associated with. cyprides and very small fragments of bones, and vegetable detritus. The white and cream-coloured 
slates and coarser limestones, or Purbeck stone, as they are termed, are also shelly conglomerates, the prevailing shells being small speeies of the genera Cyclas, Cyrena, \&c.*

The stone now quarried is in the upper part of the series of shales, clays, and limestones. Mr. Webster states, that in the thickness of 125 feet, there are more than fifty layers of useful stone; these include a remarkable deposit, 12 feet thick, termed "Cinder" by the workmen, and which consists of a regular oyster-bed. The lower 150 feet are made up of shales, clays, and shelly limestones, too friable to be of any value in an economical point of view. The total thickness, from the uppermost bed to the Portland marine limestone, is about 275 feet. $\dagger$ Fibrous carbonate of lime, in layers two inches thick, is often found adhering to the bands of marble, as in the instance observed in Sandown Bay (p. 136).

Fossils of the Purbeck strata.-From what has been stated, the reader will be aware that the fossils of the Purbeck strata are identical in their general character, with those of the upper divi-

* Some of the most ancient pavement in Ely Cathedral consists of slabs of the Purbeck bivalve limestone.

+ Mr. Webster, in Geol. Trans, vol. ii. new series. Mr. Webster mentions having found some nodular concretions of chert, containing silicified freshwater shells in the state of chalcedony; I have not obtained any specinens of this kind. 
FOSSILS OF THE PURBECK STRATA.

sions of the Wealden, described in the previous chapters. They consist of river shells, drifted land plants, bones of saurian and chelonian reptiles, with the remains of fishes, and crustaceans ; the absence of ammonites, echinites, zoophytes, \&c. being as complete as in the Sussex wealden.

Many bones of reptiles have been procured from Swanage cliffs, ${ }^{*}$ and from the quarries in the neighbourhood; but the most remarkable fossil of this kind litherto discovered, I had the good fortune to obtain, through the intelligence and liberality of Pobert Trotter, Esq. F.G.S., of Sussex.

The Suanage fosil Crocodile.-In the summer of 1837, the workmen employed in one of the quarries near Swanage, had occasion to split asunder a large slab of the fawn-coloured limestone, when, to their great astonishment, they perceived many bones and teeth imbedded on each of the exposed surfaces. As this was no ordinary occurrence,--for though scales of fishes, shells, and fragments of bones, were frequently met with, an assemblage of bones had never been

* A description of some bones of the lguanodon, found on the shore, half a mile north of Swanage, is given by Dr. Buckland in Geol. Trans, vol. iii. p. 429, new series. 
observed before,-both slabs were preserved; and Mr. Trotter, who casually visited the place, purchased them, and presented them to me. These slabs measure 3 feet 10 inches by 3 feet, and are a few inches in thickness. Many of the bones were split asunder in separating the stone, others were deeply imbedded, and of a few, imprints alone remained. Much labour and care were required to unite the serered parts of the bones, to develop the others, and bring the specimens into the state in which they now appear. On one slab, a considerable portion of the left side of the lower jaw, with two teeth, is preserved; and several teeth, and numerous dermal or skin-bones, of a very peculiar form, are dispersed about the stone.** The bones of the pelvis, and some of those belonging to the extremities, with many caudal and dorsal vertebra, and chevron bones, are imbedded in the same slab. The corresponding piece of stone bears the impression of the portion of jaw, and contains mumerous dermal bones, vertebrix, \&c. $\dagger$ Teeth and dermal bones of this reptile were among my earliest discoveries in

* These dermal bones are figured in Medals of Creation, vol. ii. p. 702.

$\uparrow$ The slab first described is figured in the Wonders of Geology, vol. i. pl. i. l3otly specimens are now placed in an upright glass case against the wall, near the doorway of the room containing the remains of the Iguanodon and other Surians, in the Gallery of Organic Remains, in the British Musenm. 
Tilgate Forest; several teetl are figured by Baron Cuvier, in Oss. Fross. tom. v., and in my "Fossils of Tilgate Forest." In the latter work portions of dermal bones, or scutes, are represented, and described as belonging to the freshwater turtles called Trionyces; and it was not until I discovered more perfect specimens, that the true nature of these bones was apparent. The gigantic Gavial of the Ganges, has rows of osseous scutes, which are deeply pitted on the external surface. Those of the Swan-

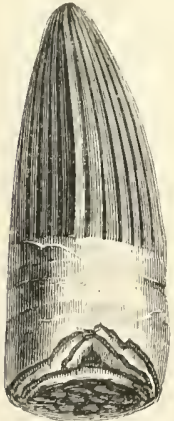

uigN. 30. -тооти ог тие rass of this reptile, which thereSWANAGE CROCODILE.

(Goniopholis crassidens.) age Crocodile are distinguished by a lateral conical projection, which fits into a corresponding depression on the under surface of the opposite angle of the adjoining plate. Numerous hexagonal and pentagonal scutes, articulated together by marginal sutures, also entered into the composition of the cuifore, must have constituted a flexible and impenetrable coat of armour, capable of resisting the attack of the most formidable assailant. The teeth of the Goniopholis (lign.30) resemble in form those of the crocodile, 
but the crown is strongly marked with numerous sharp, well-defined, longitudinal striæ, and there is a prominent ridge down the middle of each side. The successional treth are often found in the base of the perfect old teeth, as in the crocodile. Some specimens from Tilgate Forest are two inches long, and half an inch in diameter at the base.* The vertebræe are biconcave, and have an irregular medullary cavity in the centre of the bone; the chevron bones resemble those of the crocodile.

Fossil Turtles.-Waterworn bones of turtles are very common in the Purbeck strata, and several almost perfect examples of the carapace, or buckler, and of the plastron, or stemal-plates, have been discovered; a remarkably fine specimen from Purbeck, was exhibited many ycars since in Mr. Bullock's museum, in Piccadilly.

Fossil Fishes.-Detached angular scales of the well-known Wealden fish, the Lepidotus, are often met with in the clays and limestones; and many specimens of the entire fish, of a smaller species of the same genus (Lepidotus minor), have been obtained. The small hemispherical teeth, termed by the quarry-men fishes' eyes, are of very frequent 
occurrence in many of the beds. The slabs containing the Goniopholis, previously described, have numerous teeth and scales of the Lepidotus minor scattered among the bones.

The Portland Oolite.*-The series of sedimentary deposits, termed the Oolite formation by English geologists, and known as the Jura limestone on the Continent, from the mountain-range in which it is so largely developed, consists of limestones, sands, and clays of great thickness and extent, which abound in marine shells, corals, crinoiclea, articulata, and fishes-terrestrial and marine reptiles, insects, and land plants - and two or three genera of very small mammalia, referable to the marsupialia and insectivora. In this formation there are several local intercalations of fluviatile deposits, resembling the Wealden in the presence of terrestrial animals and plants, and freshwater shells. $\uparrow$ Certain beds of the Oolite (called the Stonesfield slate) contain organic remains, which, with the exception of trigoniæ and other marine shells, correspond with those of the Tilgate calciferous grits. The collocation of teeth and bones

* The term Oolite, or egg-stone, is derived from many of the limestones being composed of an aggregation of very small grains or spherules, which bear some resemblance to clusters of small eggs, or to the roe of a fish; this structure is merely concretional.

+ See Wonders of Geology, vol, ii. p. 436. 
of the Megalosaurus, Lepidotus, \&c., with stems and fruits of cyeadeous plants, presented so striking an analogy, that it led me, on my first discovery of similar fossils in the 'lilgate strata, to seek for the equivalent of the latter in the Stonesfield oolite. * In the Isle of Purbeck, the uppermost group of the Oolite only appears; it is denominated "the Portland Oolite," from the island in which the limestone has for centuries been extensively quarried. This group is separated into three divisions; viz. 1, the Portland limestones; 2 , the Portland sands; and, 3, the Kimmeridge clays, so called, from the bay of Kimmeridge, where these beds are well displayed.

1. Portland limestones. - Oolitic limestone, abounding in trigonice, ammonites, perne, plurotomarice, and other marine shells; layers and nodular masses of ehert and flint; total thickness, from 30 to 40 feet.

2. Portland sands.-Beds of white and green sand and sandstone, with concretionary masses of grit; the lower strata argillaceous; total thickness, about 130 feet.

3. Kimmeridge clay. - Dark blue clay, with

"See The Fussils of the Soulh Downs, 1822, "On the analogy between the organie remains of the Tilgate beds and those of Stonesfield, near Oxford," 1. 59 . 
septaria, and bands of sandy concretions; beds of lignite, and highly bituminous shales and clays; marine shells are very numerous; total thickness, 300 feet. One species of oyster, the Ostrect deltoidea, is characteristic of this group, and occurs abundantly in every locality.*

Geographical distribution of tile strata.The White chalk forms a narrow but lofty chain of hills, that ranges inland across the Island, from Handfast Point (section, lign. 28), to the cliff called Bats-corner, on the south-western shore. The lower cretaceous deposits appear along the southern escarpment of the downs; the chalk is also exposed to the east of Bats-corner, in Worbarrow, or Worthbarrow Bay, and in several lesser bays or coves, that have been excavated, by the long-continued action of the waves, in the Purbeck and Wealden deposits, that form the southern cliffs. The height of this chain of downs is from 500 to between 600 and 700 feet. Ballard Hill, over Handfast Point, is 584 feet, and Ninebarrow Down, 642 feet high. A line of chalk cliffs forms the coast from Bats-corner to Whitenore (see lign. 36), where the cretaceous

"Sowerby"s "Mineral Conchology" contains figures of many of the shells of the Portland Oolite; and in Dr. Fitton's Mlemoir, plates xxii. and xxiii., several species are figured and described. 
362 GEOLOGY OF TIIF ISLE OF PURBECK.

beds trend inland, and the cliffs beyond consist of the strata below the chalk. The Wealden and Hastings deposits extend entirely across the peninsula, from Swanage Bay to the southern shore at Worbarrow Bay, and form a valley, diversified with heaths and cultivated tracts, between the chalk escarpment and the next range. The Purbeck beds run in a nearly parallel direction with the Wealden, from the hills above Swanage, spreading out to the north as far as the village of Worth, and westward four or five miles, to the seashore on the south of Worbarrow Bay, and the adjacent coves.

The Portland group appears on the south-east, beneath the Purbeck at Durlstone-head, and continues along the coast to Gad-cliff, constituting the irregular tract that forms the southeastern part of the Isle of Purbeck.

Southern const of Purbeck.-- We must now take a rapid view of the most important features of the coast, from Durlstone-head to the westeru extremity of this interesting district. Swanage will be the most convenient place for the visitor desirous of exploring the geological phenomena of the eastern part of Purbeck; the numerous quarries in the vicinity, and the coast sections, being rich in organic remains. East and West 
Lulworth, two little villages near Worbarrow Bay, are the best halting-places for a survey of the south-western shores; and if the observer be tempted to extend his tour to the Isle of Portland, Weymouth, of course, will be the place of sojourn.

As the general dip of the strata is to the north, the lower beds are displayed along the southern coast; and we will now point out the most instructive localities, in proceeding from the southcastern corner of the Isle of Purbeck, to the west.

Contorted Purbeck strata. - The strata in the middle and on the south side of Durlstone Bay, are very remarkable for their broken and contorted condition, which was evidently produced when the beds were in a plastic state. Septaria, veins of calcareous spar, and crystals of gypsum, oceur in some of the clays; there are also masses of breccia, or conglomerate, composed of fragments of the undulated layers, cemented together into a firm rock.*

To the west of Durlstone Head, the Portland oolite appears; and at Tillyuthim (lign. 28) there are quarries for the extraction of the fine white limestone, here called Purbeck stone. These strata

* Mr. Webster has figured a mass of this kind in pl, xxxi. Sir II. Englefield's Isle of Wight. 
364 GEOLOGY OF THE ISLE OF PURBECK.

contain ammonites, trigoniae, and the usual Portland shells, and veins and nodular masses of chert. A bed of oyster shells, which an infiltration of calcareous matter has converted into a hard shelly conglomerate, like that of Bromley, in Kent, * occurs in the upper part of the series. The quarries at 'Tillywhim are generally visited by parties in the summer, on account of the romantic character of the scenery, and the delicious cool retreat afforded by the caverns or excavations; these are reached by a path that winds through a deep valley, strewn with masses of stonc, and the descent is by steps cut in the rock. ' ' 'o the eastward there are similar caves, formed by the extraction of the layers of limestone: fine specimens of the oyster-shell conglomerate may be obtained from near the summit of the cliffs.

Lofty perpendicular cliffs of oolite, capped with Purbeck strata, continue along the coast to the west; and at the distance of about three miles from Tillywlim, the Portland stone is worked in Windspit quarries, + which are excavations in the cliff, like those at the former place.

Ahout a mile to the west of Windspit quaries,

* See Medals of Creation, vol. i. p. 385.

$+A$ view of the eliff at Tillywhim is given by Mr. Webster, in Sir II. Englefield's Isle of Wight, pl. xxxiii.

I Represented in pl. xxxii, of the sistue work. 
the cliffs form a bold cape, called St. Adhelm's Head; and about midway between these places, the Portland sands emerge from beneath the oolitic limestones, and gradually rise towards the upper part of the cliff, as we proceed westward. The promontory of St. Adhelm's Head is a conspicuous feature of this part of the country, and is flanked by dangerous rocks, which have often proved fatal to mariners. It is a vertical section of the Portland limestone and sands, and of the underlying Kimmeridge strata; the former appearing at the top in immense square masses, and the latter below in a steep slope, covered by huge fallen blocks and fragments of stone. Deep fissures in the upper part of the cliff predict the impending ruin of other masses, and the agitation of the sea for above a mile from the shore indicates the nature of its rocky bottom; the remains, no doubt, of land which has been overwhelmed by the ocean. On the summit of this precipice are the remains of St. Adhelm's chapel, a small building of carly Saxon architecture, originally a chamtry, where masses were performed for the safety of the mariners that passed by this dangerous shore, who were expected to leave some gratuity at the first port they landed at, for the maintenance of the priest.*

- Mr. Webster. 
From this point to Gad Cliff, which, in direct distance, is about six miles, the coast is much indented, and is flanked by cliffs of Kimmeridge clay, which are capped along the middle district by Portland sand and limestone; the total thickness of the clays is about 300 feet.

Rounding St. Adhelm's Head, the coast tends northward, and a creek, called Chapman's Pool, appears on the right; beyond is Emmett's Hill, a ridge nearly 300 feet high, capped with Portland stone, resting on the Portland sands, of which a good section is here exposed.* 'To the west, the cliffs for between two and three miles are, in a great measure, composed of highly bituminous shales, and laminated clays, termed " Krimmeridge coal;" we then reach Kimmeridge Bay, an excavation formed by the sea, in the low tract of fissile argillaceous deposits which constitutes this part of the coast. The view of Gad Cliff from Kimmeridge Bay is very imposing, for in the foreground, the black bituminous clay cliffs run out into a low point, and, towering over them to the westward, the limestone summit of the distant hill is distinctly visible. The bay is partly encircled by an amphitheatre of high ground, the summits of which consist of 
Portland stone, the steep grassy slopes being composed of the Portland sands, resting on the Kimmeridge clays. Thus, then, the three divisions of the Portland oolite, as exhibited in the Isle of Purbeck, may be traced from Emmett's Hill, which is about 250 feet high, by the prominence called Encombe Point, through Kimmeridge farm to beyond Gad Cliff, where they sink beneath the sea at Worbarrow Knob, on the eastern side of the headland of Purbeck beds, that forms the southern point of Worbarrow Bay.* The Kimmeridge clay reappears in Ringstead Bay, between seren and eight miles beyond Gad Cliff, to the west of the chalk at Whitenore; thence to Weymouth, the lower beds of clay become charged with sand and calcareous earth, and pass insensibly into the limestone strata of the Oxford oolite.

Kinmertdge Conl. - The strata in the immediate ricinity of the place from which the name of the group is derived, are composed of bituminous fissile shales and laminated clays, alternating with thin courses of brown limestone. As some of the layers are so largely charged with carbonaceous and bituminous matter as to be used for fuel,

* Princiully from Dr. Fitton's Memoir and sections : my own observations along this part of the coast have been very limited. 


\section{GEOLOGY OF TUE ISLE OF PURBECK.}

the most combustible beds of these substances are commonly known as the Kimmeridge Coal.* "This coal," observes Mr. Webster, "is merely a slaty clay strongly impregnated with bitumen, and does not exhibit any signs of vegetable structure. It burns very readily with a brisk flame, affording a good heat, but emitting a very disagreeable smell." +

Beneath the bituminous beds, are clays, shales, and thin bands of limestone, containing the Ostrea deltoidea, Ammonites triplex, Gryphea virgula, and other shells characteristic of this division of the oolite formation.

South-west const of Punbeck. - TVe have now arrived at that part of the coast, where the range of vertical chalk, of which we exanined the eastem extremity at Handfast Point, appears in the inland recesses of several little bays or

* At Clilley in Sussex, sandstone strongly impregnated with bitumen (called "pitchstone" by the neighbouring peasantry,) and much resembling in appearance some of the Kimmeridge beds, is found beneath the silt in Pevensey levels. It is described in "the Fossils of the South Downs," p. 76 . I have not been able to examine this bed in sitis; it probably belongs to the Wealden formation.

† Sir 1I. Englefield's IsIe of Wight, p. I87. I may here notice that there are often found at Kimmeridge, Encombe, and the surrounding neighbourhood, circular piees of shale which have evidently been turned in a lathe. They are of the size of a half crown, and have a few circles drilled partly through on one side; they are termed by antiquaries, "coal-money," and are supposed to have passed as tokens in ancient times-perhaps they were current only in the peninsula. Several are occasionally found carefully buried beneatl two stones. 
coves, which the sea has excavated along this shore; nine sections of the beds between the chalk and the Portland oolite being exposed, within a distance of five miles. The Wealden, Purbeck, and Portland strata, which on the south-eastern coast form on the south of the chalk downs a tract of country of considerable breadth, are here diminished to one-tliird of a mile, or even less; so that in the space of a few hundred yards, the entire series may be examined; for the strata so rapidly converge to the westward, "that the total distance from the top of the greensand to the beginning of the Portland oolite, which is about two miles and a half between Ballard Downs, and Durlstone Head, is but 150 paces in Durdle Cure."**

The plan of the coast, ligm.31, from the western end of Worbarrow Bay to Whitenore, shows the situation of the bays we are about to examine. The "Sxine's Back" is part of the lofty range of chalk downs, which, interrupted here and there by deep valleys, in one of which the village of West Lulworth is situated, continues westward to Chaldon Downs, forming the inland barrier of the Coves, and the line of cliffs from Bats Corner to Whitenore Point. The scenery in this part of the * Dr. Fitton. 


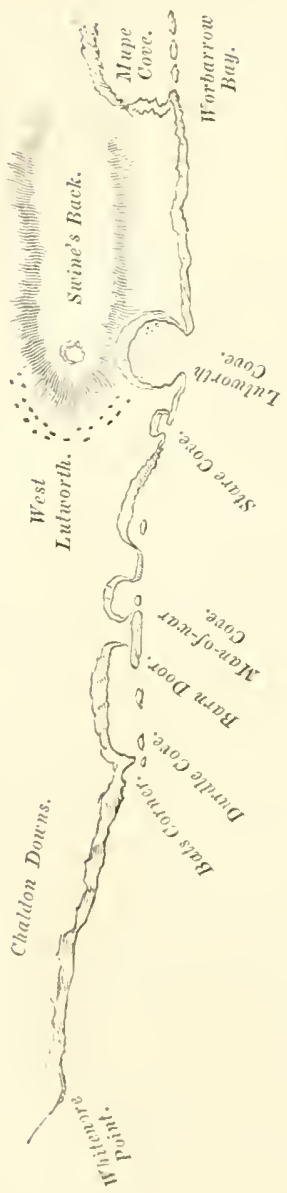

$\therefore$ peninsula is highly picturesque, whether viewed from the sea, or from the summits of the downs. A magnificent view of the Dorsetshire coast, is obtained from atumu$\cong$ lus on the brow of a . very lofty precipice of chalk, that overhangs Worbarrow Bay; it is admirably represented in plate 35, of Sir H. Englefield's work ; $P l$. XVI. is a slight sketch of the same. From this height we look across the bay to the westward; the path down to the shore, is seen beyond the projecting point of the chalk cliff. 'The detached rocks in the sea are 
$\vec{z}$

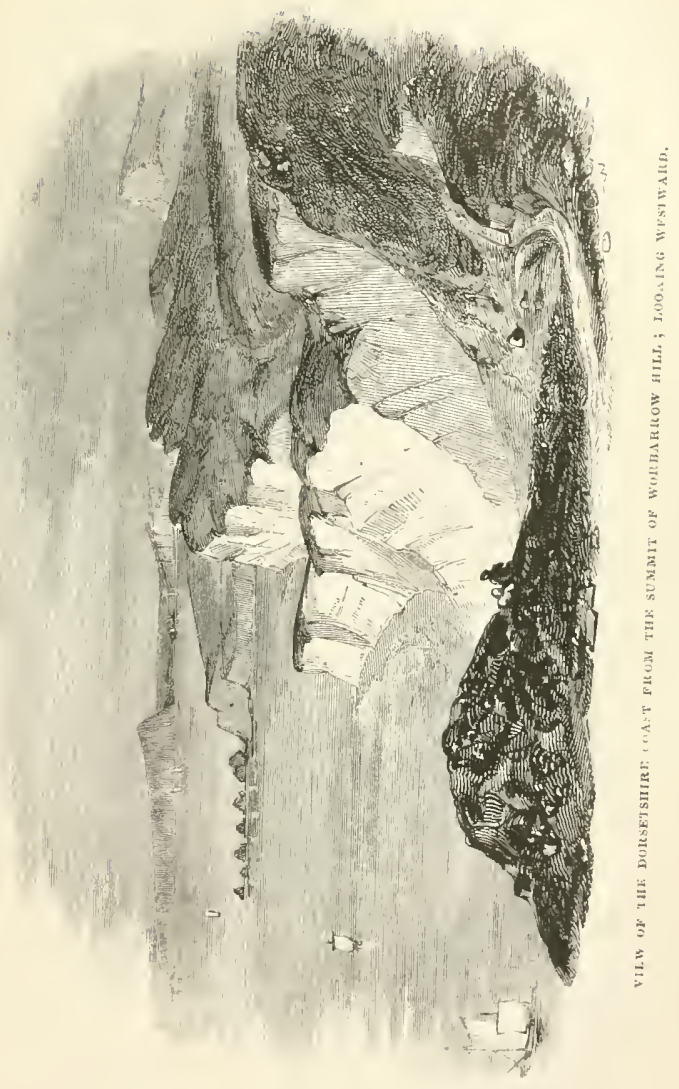



mark the western boundary of the bay; the low cliffs are Purbeck and Wealden strata. The hill in the middle of the landscape is the Swine's Back, beyond which is Lulworth Cove ; the Isle of Portland appears in the remote distance. The deep sinuosities made in the cliffs by the inroads of the sea are very conspicuous from this elevated position, and the physical characters of the district produced by its geological structure are well displayed. The height on which we are standing, is the sudden termination of the vertical chalk range which appears in the section at Handfast Point; and we can trace the clialk downs extending four miles further westward, in the line of seacliffs beyond the coves. Thus in the Isle of Wight, the chalk cliffs at Freshwater appear to the west of the Wealden strata of Brook and Compton Bays (p. 210); and should the sea continue to encroach on that part of the coast of the "beautiful Island," the chalk would at length be reached, and form the inland barrier of a semicircular bay, bounded on the sides by the lower cretaceous deposits, and on the sonth by Wealden strata; as in the Coves of Purbeck.

To the south, the chain of hills composed of Purbeck and Portland beds appears; and the intermediate tract is a fertile valley, formed by the 
374 GEOLOG OF THE ISLE OF PURBECK.

Wealden clays, and sands. 'Thus the northern barrier of the coves consists of precipitous chalk cliffs, the entrance is formed by rocks of the Portland and Purbeck limestone, and between these, is a low coast, composed of the less durable strata of the $\mathrm{W}$ ealden. These bays expose, in fact, transverse sections of the hills of Portland and Purbeck strata- of the clays and sands of the IVealdenand at their back, chalk precipices of great height, formed by the destruction of the southern face of the Downs.

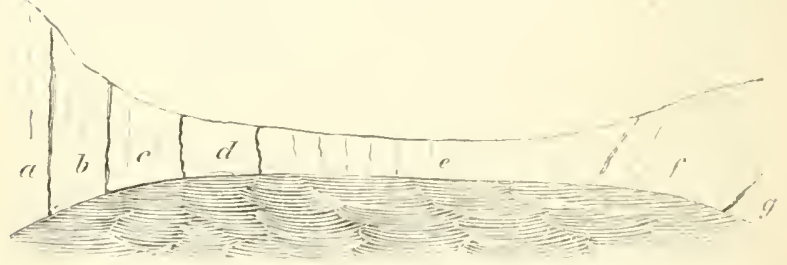

LIGN. 32.-PLAN OF THE STRATIFICATIUN OF THF COYES OX THE SOITH WESTERA COAST OF THE ISLE OF PUHBECK.

$a$, Chalk. b, Chalk-marl. e, lirestone. d, Galt. p, Wealden. $f$, Purbeck. g, Portland oolite.

'The plan of the stratification, lign. 32, given by Mr. Couybeare, affords a clear illustration of this structure. 'The Portland and Purbeck beds $(q, f$, dipping inland, in an angle of from $45^{\circ}$ to $60^{\circ}$, 
form the outer capes and reefs-the vertical cretaceous strata $(a, b, c, d$,$) the inland cliffs; and the$ wealden (e), the intervening portion. The latter in many of the sections, have the same contorted appearance as in the cliffs on the south of Durlstone Bay. The solid layers of sandstone and limestone, though broken, preserve regular planes of stratification, having from their compactness resisted the violence of the movements to which they have been subjected; but the superincumbent plastic argillaceous beds, have been bent into irregular curves, by lateral pressure. Hence too the peculiar form of the coves; for the firm barrier of Portland stone, being only partially broken through, scarcely more than onethird of the circumference of these bays is open to the sea.

Wonbarnow Bay.-On the sonth side of Worbarrow Bay, the junction of the Hastings sands of the Wealden, with the Purbeck strata, is risible, and Dr. Fitton has described the following section, which was observable at the time of his visit; from the crumbling nature of the cliffs, a clear view of the beds is not always attainable.

Grey and yellow sand, oceupying on the shore, 13 paces.

A space concealed at the top; where visible the beds consist of clay, with lignite; concretions of quartzose grit with ryclates. At the bottom, 9 paces. 
Beds containing stone with small paludinæe cemented together by green ealcareous earth; called "marble," and "marble-ray," by the quarry men; 16 paces.

About 25 paces more of the cliff" are made up of brown and grey clays, with bands of bluish grit, and thin beds of stone.

Contorted clays and limestones, which extend to the prominence called Worbarrow knob; between this point, and Gad Cliff on the east, a thickness of 50 feet eonsists of alternating layers of clays and limestones, which are also much undulated.

On the west side of Worbarrow Bay, low insulated masses of Purbeck rocks appear on the shore. In crossing this bay in a boat, a fine view of the lofty chalk cliff is obtained; and through the valley in the centre of the cove, Lulworth Castle forms a striking object in the distance. At a spot in this bay called $A$ rish-mel, vertical chalk and flint strata, as at Handfast Point, are well displayed.

Lulworti Cove.-The picturesque scenery of this part of the Dorsetshire coast was well known to tourists, and the little village of West Lulworth, which is charmingly situated in a deep chalk valley, was a frequent resort of water-parties from Weymouth, during the smmmer, ere its attractions were heightened by the discovery that the geology of the country is in the highest degree interesting. West Lulworth, of which a sketch is given in I\%. XVIII. (p. 381), is about two miles west of 


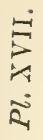

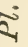
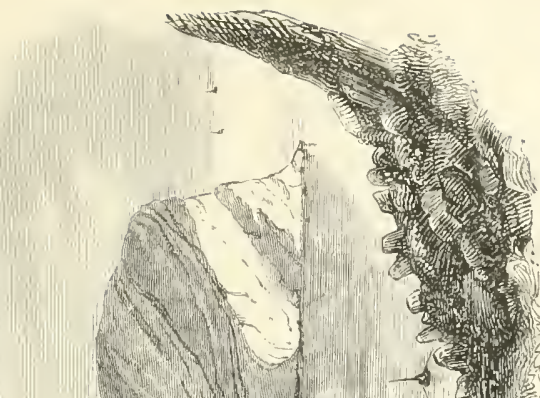

1.

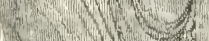
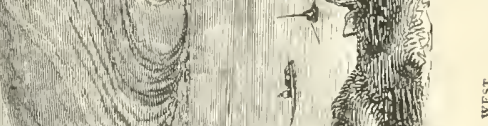

11.W
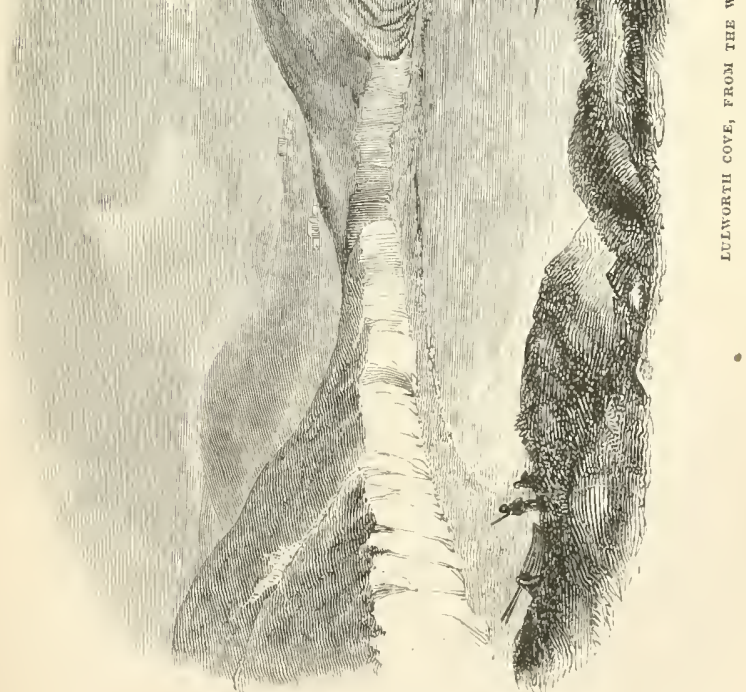

Lulworth Castle, and a quarter of a mile from the cove. The hill immediately above the village in this view, is the western termination of the chalk downs, called the Swine's Back (seelign. 31, p. 3\%0), which is cut into by the cove, and forms a precipitous chalk cliff in the middle of the bay. The nearest headland seen beyond the core is Gad Cliff; that in the remote distance is St. Adhelm's Head.*

Lnlworth Cove is about 1300 feet across, and is of sufficient depth for ressels of above a hundred tons burden, to remain at all times in perfect shelter and security. A copious and transparent spring bursts out from a cavern just below the village, and after turning a mill, flows into the

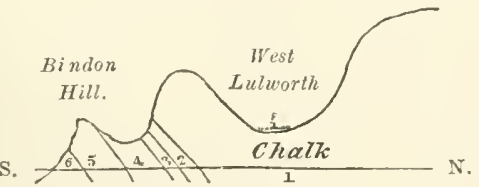

LIGN. 33. -PLAN OF THE STRATA ON THE WEST GIDE OF LULWORTH COVE.
1. Chalk.
2. Firestone.
3. Galt.
4. Wealden.
5. Purbeck.
6. Portland stone.

bay. The rock from which the rater issues, is composed of sharp fragments of flint imbedded in chalk rubble, cemented together by stalactitical deposition.

* Boats may be obtained at Lulworth and Worbarrow for excursions along the coast. 
The cliffs around this semicircular basin present the same section as those in Worbarrow; the

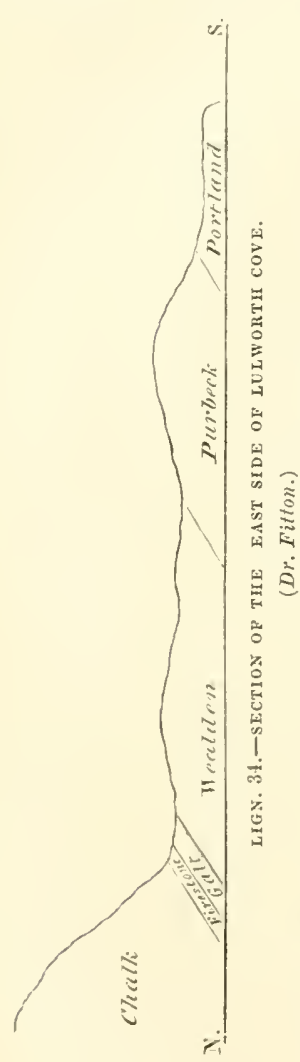
entire series of strata, from the chalk to the oolite, being clearly exposed. The plan, lign. 33, explains the relative position of the deposits, as seen on the west side of the bay. On the east side, a similar section occurs, as represented in lign. 34; and the chalk, firestone, galt, Wealden, Purbeck, and Portland beds, are seen in their natural order of superposition, in a distance of between five and six hundred yards, proceeding from north to south.

A ricw of this part of the bay, from the west, is given Pl. XVII. In this sketch a small portion of the base of the chalk downs is visible on the left; the low cliffs that sueceed, and wind round the middle of the bay, are the lower cretaceous strata, and the clays and sands 

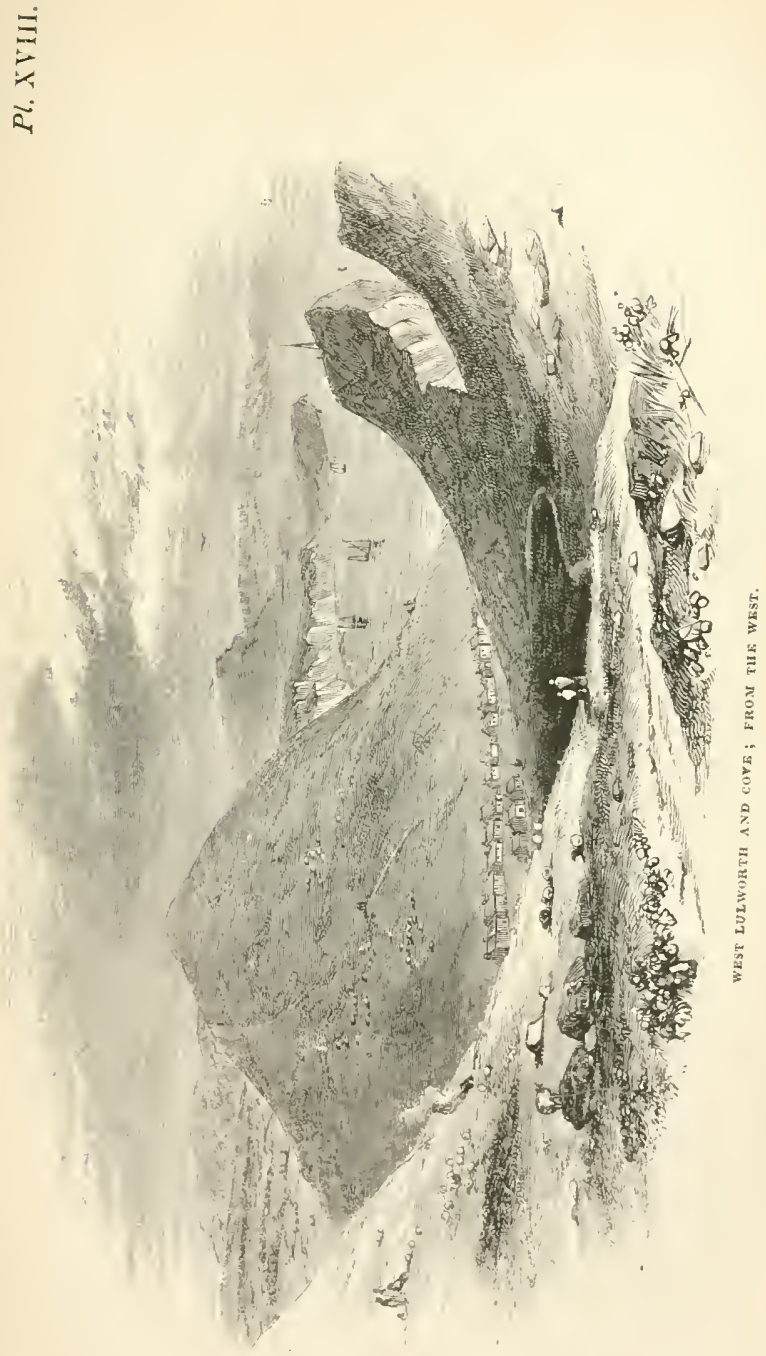

of the Wealden. The headland at the entrance of the cove, consists of contorted Purbeck beds, resting on the Portland oolite, of which large masses project on the shore. The appearance of the undulated layers of Purbeck limestone, is very striking in the weathered portions of the clift, from the intermediate clays having been worn away, and the bands of stone left prominent. The blocks on the right, in the foreground, are of Purbeck limestone, and extend towards those that form the opposite bar.

Dr. Fitton, with characteristic accuracy and minuteness of detail, has given measurements of the spaces occupied by the different groups of strata below the chalk in Lulworth Cove. The firestone and galt are about 150 feet; the Wealden beds, 600 feet; the Purbeck, 450 feet; and the Portland, 240 feet. 'The fossils here met with are lignite, and a few paludinæe and uniones, in the Wealden; and in the Purbeck, shells of the same genera oceur in layers, and mussel-shells abundantly in a coarse green sand-rock, as at Durlstone Head.

Fossil trees.-Seams of lignite are numerous in the Wealden sands and clays, as in Swanage Bay, and in Brook Bay, in the Isle of Wight. In the Portland strata, a little way to the eastward, are 
384 GEOLOGY OF THE ISLE OF PURBECK.

petrified trees, still attached to the soil in which they grew. 'These were first observed by the present Dean of Westminster, and Sir H. De la Beche.* The sketch in lign. 35, copied from the "Memoir on the Creology of Weymouth," by these distinguished geologists, illustrates the position of the strata and fossil trees.

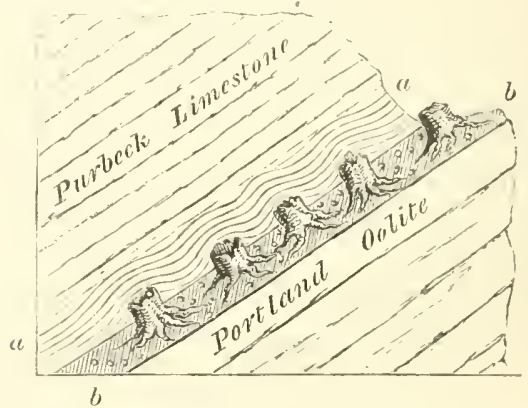

LIGN. 35. - SECTION EXPOSED IN THE CLIFF EAST OF LULWORTH COVE.

$a, a$. Stratum of calcareous laminated stone, termed "burr."

$b, b$. The "dirt-bed," with fossil trees.

(From the Geotogical Transaetions.)

On doubling the rocks on the east corner of the cove, the Purbeck beds are seen resting on the oolite, and forming "South Cliff," which is surrounded by the insulated masses of rock that appear on the west side of Worbarrow Bay (see Pl. XVI. p. 371$)$. It is about a furlong to the east of 
Lulworth Cove, in the highly inclined strata of the cliff, that a considerable number of petrified trunks of trees are exposed. Some are entirely laid bare by the washing of the sea, and others partly so; but several are almost wholly encased by concretions of soft burr-stone, and have their roots fixed in a layer of black earth (termed dirt-bed by the quarrymen); in precisely the same relative position, and interspersed with similar rounded fragments of limestone, as in the fossil forest of the Isle of Portland, hereafter noticed.

The lowermost strata are the Portland oolitic limestones, full of marine shells; on them is superimposed the layer termed the "dirt-bed," with the fossil trees. This is covered by creamcoloured calcareous stone disposed in very thin undulated laminæ, and locally termed "soft burr ;" and above are shales, and thin bands of limestone, belonging to the lowermost beds of the Purbeck.

There are also layers of chert containing chalcedonic casts of freshwater shells, in the cliff just above the sea level.**

Durdee, or Barn-door Cove. - There are sereral smaller bays, which are worth examining

* On the hills near Lulworth, there are detached blocks of the Hertfordshire siliceous pudding-stone, lying upon the chalk; and large masses of this conglomerate may be seen in the street of West Lulworth, and in the walls of some of the cottages. 
386 GEOLOGY OF TIE ISLE OF PURBECK.

if the visitor's leisure will permit: these are DIupe Core, which is situated in Worbarrow Bay (see lign. 31, p. 370); Stare Core, * near Lulworth; and Man-of-War Cove, half a mile further to the west, so called from a long rock at the entrance, named the Man-of-War. In each of these bays the same geological phenomena are observable. They may all be approached from the land, but are seen and studied to most advantage from the water.

Durdle, or Barn-door Cove, is remarkable for a natural perforation or archway, formed by the waves in a projecting erag of the nearly rertical Portland oolite, which bounds the eastern cape of the Bay. This arch, commonly called the Barndoor, is large enough to admit the passage of a boat with the sails up; and in very fine weather it is customary for the pleasure parties from Weymouth to sail through it. The western cape of the bay is composed of rertical strata of chalk and flint, and is called Bats Comer (see lign. 31, p. 3\%0). This bay, therefore, differs from those above described, in presenting but one section of the strata, which commencing with the chalk on the west, and

\footnotetext{
* Stare Cove,-so ealled from several eaverns through which the sea daslies with a loud roar. In this cove the eontortions of the Purbeck beds are very grotesque and remarkable. Pl. xliv, of Mr. Webster, is a fine view of this Jittle bay.
} 

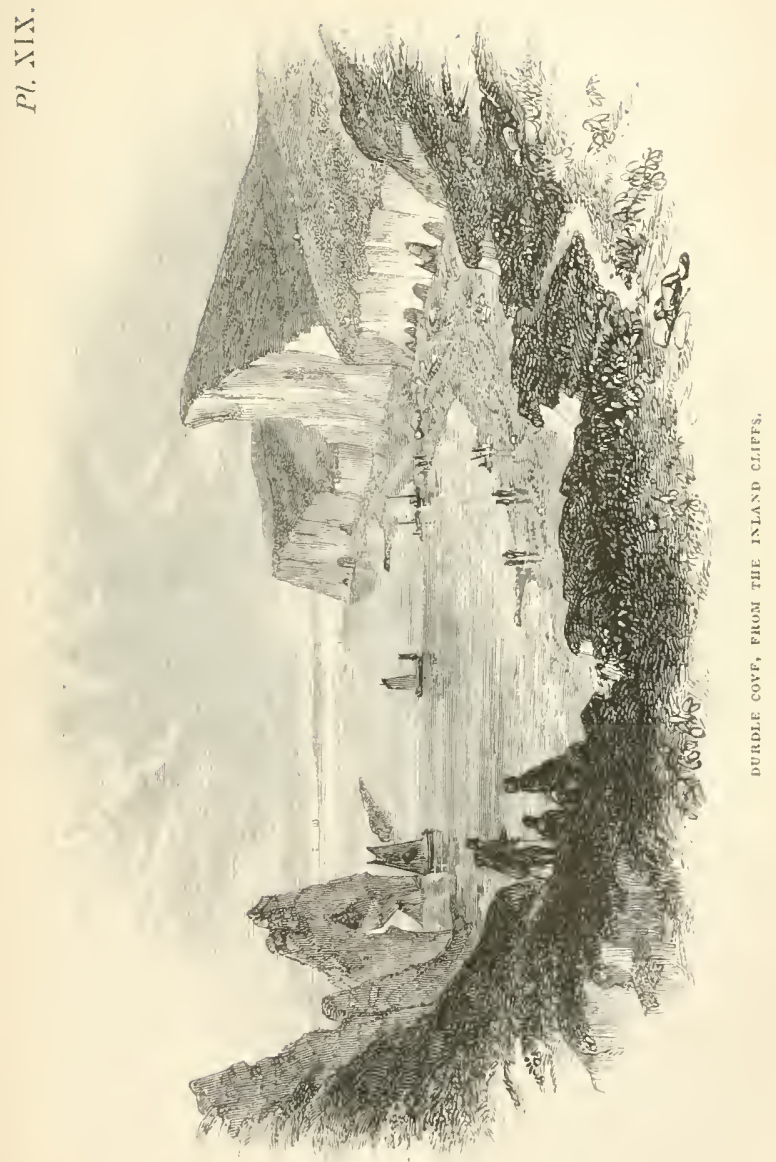

succeeded by the lower groups, terminates in the Portland oolite on the east. The view by Mr. Webster (see Pl. XIX.) admirably illustrates the geological structure of this beautiful bay. In this sketch the chalk appears on the right, forming the high cliff on the western cape, termed Bats Corner; in passing thence, the firestone, galt, Wealden, and Purbeck strata, successively appear, and lastly the Portland rocks, which terminate the point on the left of the view, as indicated by the archway called the "Barn-door:" A line of low oolitic rocks stretches across the mouth of the bay.

Chaldon Downs.-Proceeding to the westward, we lose all traces of the beds below the chalk; the chalk cliffs, which are between 200 and 300 feet high, form the western headland of Durdle Cove, and continue along the coast to Whitenore Point, the eastern cape of Weymouth Bay, a distance of about two miles (lign. 36, p. 390); these strata present some interesting features. In these cliffs, the gradual transition of the chalk beds from a vertical to a gently inclined position, is clearly shown. 'The vertical strata at Bats Corner, partake of the same characters as those at Handfast Point; the chalk being much indurated, and the flints shattered. A quarter of a mile to the west, the layers of flint are nearly horizontal, being 
united with the vertical by a gentle curve, as shown in lign. 36 ; and in these beds the chalk possesses its original friable texture, and the flints are entire.

Point.

Chaldon Downs.

Bats

Corner.

W.

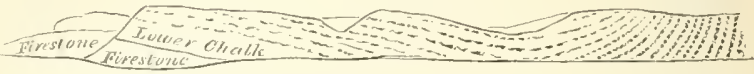

LIGN. 36. - CHALK CLIFFS, ON THE SOUTII-WEST COAST OF THE ISLE OF PURBECK; FROM BATS-CORNER TO WHITENORE-POINT.

(The Rev. W. D. Conybeare.)*

'I'owards Whitenore the firestone and galt appear at the base of the cliffs. At this spot the chalk trends inland, and thence to Weymouth the coast is flanked by cliffs and flat shores of the inferior strata. From the summit of the chalk cliff at Whitenore, which is about eight miles E.N.E. of Weymouth, the view to the west shows numerous little bays, hollowed out of the shore by the action of the sea along the coast, as far as Weymouth, and Portland Island is strongly defined on the horizon over the sea. To the eastward are seen the chalk cliffs extending to Bats Corner, and the projecting capes of Durdle and Lulworth Coves, and the summit of Worbarrow Down.

Ringstead Bay. - To the west of Whitenore, the Kimmeridge clay, which we lost sight of at 
Gad Cliff (see p. 366), reappears in Ringstead Bay, and a good section of the strata is exposed in the cliff. Proceeding towards Weymouth, the clays in the lower part of the series gradually become sandy and ealeareous, and pass insensibly into the Oxford oolite.

In Ringstead Bay, there is a striking example of that kind of displacement, which is geologically termed a fault; signifying a rertical or diagonal fissure through the strata, accompanied either by a subsidence, or an ripheaval, of one side of the dislocated masses. In this instance the beds, consisting of chalk, firestone, and oolite, on the south side of the fissure, are thrown down much lower than those from which they have been separated. This phenomenon is connected with the displacements which the districts we have passed orer have undergone. The line of disturbance we traced through the Isle of Wight, forming the antichinal axis from east to west, continues through the Isle of Purbeck from Swanage Bay to Lulworth Cove and the adjacent bays, and is prolonged westward through the vale of Weymouth, to the Chesil Bank; the strata dipping respectively north and south, on each side the principal axis of elevation. The transverse valleys which here and there intersect the chains of hills, have 110 doubt originated from fractures oceasioned by the 
tension to which the strata were subjected during their elevation, by the expansion of elastic vapours, or heated erupted rocks, far beneath the surface. For Mr. Hopkins has shown, on mathematical principles, that tabular masses of rock elevated by a force from below, must have been exposed to two sets of tension, which would produce longitudinal and transverse vertical fractures at right angles to each other; and the direction of the principal fissures, or lines of fracture, in the tracts of country we have surveyed, remarkably coincides with this theoretical deduction.

Pseudo-volcano.-A circumstance connected with the bituminous property of the Kimmeridge clay, which happened in Ringstead Bay some years since, may here be mentioned. In September 1826, at Holworth Cliff, and adjacent to the promontory of Whitenore, a spontaneous combustion of the bituminous shale occurred, and burst forth with considerable volumes of flame, and exhalations of sulphureous vapours. It continued smouldering for many years, and the surrounding clay and shale were burnt into cellular slag. This combustion probably originated in the heat produced by the decomposition of pyrites, with which the strata abound.*

* See the Memoir on the Geology of Weymouth, \&c. Geol. Trans. vol, iv. 
The cliff in Ringstead Bay is rich in the usual fossils of the Kimmeridge beds; and Osmington Cliff, west of Ringstead, abounds in Trigoniæ and other shells of the Oxford clay, many of which are in a beautiful state of perfection. Crystals of sulphate of lime, or selenites, are common in the clays.

The Isle of Portland.-Though beyond the limits originally prescribed to these excursions, the Isle of Portland, which we have seen looming in the western horizon during the greater part of our progress from the Isle of Wight, is so intimately related in its physical structure with the country over which our observations have extended, that some notice of that interesting spot is necessary, to afford a comprehensive view of the geological phenomena, which this volume is designed to illustrate.

The Isle of Portland is a bold headland on the south of Weymouth, about four and a-half miles in length, and two in breadth, united to the mainland by a bar of shingle termed the Chesil Bank. It presents a precipitous escarpment on the north about 300 feet in height, and declining towards the south, appears, when viewed from the east or west, like an insulated inclined plane rising abruptly from the sea. The substratum or foun- 
dation of the Island, consists of the Kimmeridge clay, which attains a considerable elevation on the north; this is surmounted by beds of Portland sands, and thick strata of the oolitic limestone so well known as the Portland stone, which is extensively worked in numerous quarries. The strata dip to the south at an angle which corresponds with the profile of the Island. The coasts are steep, the base of Kimmeridge clay forming a talus surmounted by perpendicular crags of oolite; in the north-east cliff, there are beds of bituminous shale like those in Ringstead Bay. The southern extremity consists of low limestone cliffs, which are worn into numerous caverns by the force of the waves.

The summit of the northern brow to a depth of upwards of twenty feet, is formed of a series of freshwater strata superimposed on the uppermost bed of oolite, which is locally termed "the Cap." These belong to the Purbeck, and present the same remarkable phenomena as were observed in the cliff to the east of Lulworth Core (see p.384). Mr. Webster first directed attention to the highly interesting facts here disclosed.

The Kimmeridge clays of Portland resemble those we have examined in Ringstead Bay, and in the Isle of P'urbeck. 'T'he lower beds of oolitic 
limestone immediately above the clay, contain nodules and veins of flint and chert, like those at Durlstone Head; the middle group is full of trigoniæ, terebræ, eythereæ, ammonites, and other characteristic marine shells of the oolite; and the upper series, to within twenty feet of the surface, consists of the fine arehitectural stone which is locally termed the white-bed. Upon this are three or four feet of limestone, full of cavities left by a layer of shells, of which the casts only remain; and above, is an irregular bed of flint nodules, covered by a thin stratum of earthy oolitic detritus. Beautiful yellow sulphate of barytes, called sugar-candy-spar, and stalactites of calcareous spar, occur in the fissures of the limestone.

The petrified forest.-U U Don the uppermost oolitic stratum, is a layer a foot thick, of very dark brown friable loam, which appears to have been a bed of vegetable mould. It contains a large proportion of earthy lignite, and like the modern soil on the surface of the Island, waterworn stones, and pebbles. This layer is called the "dirt-bed" by the quarrymen, and in and upon it are stems and branches of coniferous trees, and plants allied to the Cycas and Zamia. Many of the trees and plants are standing erect, as if petrified while growing 
undisturbed in their native forests. Their roots extend into the soil of the dirt-bed, and their trunks into the superineumbent strata of limestone.**

As the Portland building stone lies beneath these beds, and the Cap is only used for lime, the fossil trees are removed and thrown by as useless, and the dirt-bed cleared away, to arrive at the more valuable material. On one of my visits to the Island, the surface of a large area of the dirtbed was exposed, preparatory to its removal, and the appearance presented by the fossil trees was most striking. The floor of the quarry was literally strewn with fossil wood, and before me was a petrified forest, the trees and the plants, like the inhabitants of the eity in Arabian story, being converted into stone, yet still remaining in the places they occupied when alive! Some of the trunks were surrounded by a conical mound of calcareous carth, which had evidently, when in the state of mud, aceumulated around the stems and roots. The upright trunks were in general a few feet apart, and but three or four feet high; they were broken and splintered at the top, as if the

\footnotetext{
* The diagram of the fossil trees in Lulworth Cove, p. 384, if placed with the lines of stratification in a horizontal josition, will serve to illustrate this description.
} 
trees had been snapped, or wrenched off, at a short distance from the ground. Some were two feet in diameter, and the united fragments of one of the prostrate trunks, indicated a total length of between thirty and forty feet. In many examples portions of branches remained attached to the stems. The external surface of all the trees I examined was weatherworn, and resembled that of posts and timbers of groins and piers within the reach of the tides, and subjected to the alternate influence of the water and the atmosphere. There were no vestiges of the bark in a carbonized state, nor of the natural external surface of the stems, as in the prostrate trees at Brook Point in the Isle of Wight (see p. 281.)*

The cycadeous plants occur in the intervals between the trees, and the dirt-bed is so little consolidated, that I dug up with a spade several specimens that were standing erect, in the position in which they originally grew. These plants, though related to the Cycader (p. 290), are referred by M. Adolphe Brongniart to a new genus, which he

* In the Botanic Gardens in the Regent's Park, there are several magnificent specimens of the Portland trees, with the trunks remaining upright in the mounds of stone, and the silicified roots extending into the hituminous rubble of the dirt-bed. They are placed near the foot of the artificial mount in the pleasure grounds. A great part of the stone-work of the cascade in the Colosseum in the Regent's Park, is constructed of fragments of the fossil wood of Portland. 
has named Mantellia. There are two species; one is short, and of a spheroidal form (M. nidiformis); the other is longer, and sub-cylindrical (M. cylindrica): the specimens of the former species are called "Crous'-nests" by the workmen, who believe these plants to be bird's nests, originally built by crows in the fossil trees, which have become petrified. The largest specimens are about two feet high, and three feet in circumference.**

The Pine trees and the Mantellix are completely silicified, and their internal structure is beautifully preserved in many examples; the wood, when microscopally examined, displays the Araucarian structure (see p.283). A cone has been found in the dirt-bed, which Dr. Brown considers to be closely related to the fruit of the Norfolk Island Pine (Araucaria excelsa). $\downarrow$ The Portland and Isle of Wight fossil coniferæ appear to belong to one species.

Above the dirt-bed are layers of finely laminated cream-coloured limestone, the total thickness of which is about ten feet; in these beds I have not discovered any traces of organic remains,

* These fossil Cycadea are admirably illustrated by Dr. Buckland in Geol. Trans. vol. ii. new series; and also in his Bridgewater Essay. A fine suite of specimens, formerly in my collection, is exlibited in the British Museum.

+ Ur. Fitton. 
but Dr. Fitton mentions the occurrence of casts of Cyprides. These strata are covered by the modem vegetable soil, which but little exceeds in depth the ancient one above described, and instead of supporting cycadeous plants, and pineforests, barely maintains a scanty vegetation, there being scarcely a tree or shrub on the whole Island.

There is a seam of black earth at the distance of five feet, and another two feet lower, beneath the dirt-bed, indicating two short intervals during which regetable matter had begun to accumulate on the surfice of the uppermost beds of Portland stone, when they were first emerging above the level of the sea. In these layers Dr. Fitton observed remains of cycadeous plants.*

The dirt-bed extends through the north of Portland, and appears, as we have seen, on the coast of the peninsula of Purbeck. It has been discovered by Dr. Buckland near Thame, in Oxfordshire, and by Dr. Fitton, in the vale of Wardour. It also occurs at Swindon, Wilts, where fossil coniferous wood abounds, and some specimens of cycadex have been obtained; and

* See Wonders of Geology, vol.i. p.362. For a detailed account of the Portlaud quarries, and the phenomena concisely described in the text, consult Dr. Fitton's "Mcmoir;" and Dr. Buckland and sir H. De la Beche, "On the Geologry of Weymoutlı," Geol. Trans. vol. iv. second series. 
between Stone and Hartwell, where it is covered by cream-coloured freshwater limestone, resembling the Cap of Portland, in which wings of Insects, and leaflets of the Wealden ferns, have been discovered by the Rer. P. B. Brodie,* and my friend, the Rex.J. B. Recude, Vicar of Stone. In the tertiary freshwater beds at Binstead (sec p. 105), there is a stratum of bituminous earthy loam so like the dirt-bed, that it seems probable it may have had a similar origin, and be the remains of a layer of vegetable mould.

Organic remains. - The common species of marine shells, already mentioned as characteristic of the strata below the Purbeck, oceur more or less abundantly in the several localities previously mentioned. In the Portland stone, one species of ammonite, of a very large size, hence named Ammonites giganteus, is often met with, and good specimens may be procured of the quarrymen. The fossil wood is to be found in most of the stone quarries, and the cycadeous plants, called

* See the highly interesting work of Mr. Brodie, entitled, "A History of the Fossil Insects in the Secondary Rocks of England," I vol. 8vo, with 10 plates, pubiished by John Van Voorst, 1845. Mr. Brodie has discovered numerous remains of small insects, belonging to forty-eight families and genera, in the Wealden strata of Wilts and Bucks. I have not been so fortunate as to deteet any vestiges of lnsects in the Wealden of the lsle of Wight and Sussex; but I have two or three wings of small beetles, from Kent, and of neuropterous insects from near stone, in Buckinghamshire. 
Mantellic, may be purchased of the workmen, to whom they are known as "Crous' nests." *

I an indebted to $1 / r$. Damon, of Weymouth, $\uparrow$ for the following notice of localities, which may afford useful hints to visitors :-

Ringstead Cliff.-From the Kimmeridge clay, Mrr. Damon bas obtained specimens of Pholadomya, Terebratula, Trigonia, Modiolu, Ostrea deltoidea, Mya, Pleurotomaria, Phasianelle, Ammonitestriplex, A. Gowerionus, \&c.

Whitenore.-In the chalk marl, near the base of the eliff, after recent falls, may be collected specimens of Ammonites, Turrilites, Scaphites, Baculites, Terebratula, Pleurotomaria, Natica, Buccinum, and several kinds of Echinites. The white chalk is not rich in organic remains.

At Osmington, two miles west of Whitenore, the firestone rests on Kimmeridge clay, and contains Exogyra conica, Pecten quinquecostatus, Cucullea, Serpula, Sharks' teeth, \&c. The Kimmeridge clay yields beautiful Trigonia, Ostrea deltoidea, \&c.

On the shore opposite Weymouth, between Redcliff and Osmington, the Oxforl oolite abounds in shells belonging to npwards of twenty genera.

On the south side of Weymouth, a quarter of a mile east from

* At the little village of Chesilton, which is inhabited by some of the quarrymen, I have always been able to purchase specimens. Should the visitor wish to obtain a considerable length of the stem of a tree, with branches attached, it may be well to caution him to beware of imposition; a specimen, sent to me as an entire trunk, was made up of discounected portions of stems and branches, belonging to several trees, ingeniously fitted and cemented together.

† A fine collection of recent, as well as fossil shells, properly named, may be purchased at $M r$.Damon's establishment at Weymouth; also most of the rare species of fossils from the neighbourhood.

In London, fossils from the localities mentioned in the text, properly namel, as well as specimens of other British fossils, \&c., may be obtained, at moderate prices, of $\mathbf{M r}$. Henry Stutchbury, 61, Great Russell-street, opposite the British Museum; and of Mr. Tennant, 149, Strand. 
Sandfoot Castle, the Coral-ray is full of sliclls and corals. A fine spiral univalve, the Nerinea Goodhalli (Greol. Trans. vol. iv. pl. xxxiii. fig. 12) is found here.

Near Black-rock, lalf a mile from Weymouth, the Oxford clay abounds in fossils, which can, however, only be procured by digging through a bed of alluvial soil, two feet thick.

The upper bed of Portland oolite, called the "Roach," is a congeries of casts of Trigonia, Perma, Terebra, Ammonites, Lucine, \&c. Scalcs and tecth of a species of Lepidotus are sometimes found in the Portland stone.

Magnificent Septeria, vcined with calcareous spar, are found in the Oxford clay, and are eut and polished for tables, slabs, \&e.*

With this brief account of the Isle of Portlaud and its petrified forest, these Excursions must tcrminate. To the Geolorist, this umpretending volume will, I fear, present but little of novelty or interest, and probably be useful only as a guide to the most important localities; but to the Creneral Reader, who may be induced to visit and explore the "Beautiful Island," and the picturesque scenes described in the preceding pages, I would fain hope that it may prove a source of pleasure and instruction, by opening to his mind new and inexhaustible fields of inquiry, replete with objects of surpassing interest, and which the uninformed and incurious tourist would pass by umotieed or disiegarded.

* A fine collection may be seen at the establishment of Mr. Ragget, Statuary, on the South Parade, Weymouth. 


\section{R E T'ROS P E C T.}

Is attempting to interpret the natural records of the earth's physical history, the Geologist is often in the condition of the Antiquary who endeavours to decipher an ancient manuscript, in which the original characters are obscured and partially obliterated by later superscriptions. It is, indeed, frequently difficult, and sometimes impossible, to determine the syuchronism of those geological changes, of which the only indications are insulated and but obscurely related phenomena. Bearing in mind the caution of a distinguished philosopher," "that the language of theory can never fall from our lips with any grace or fitness, unless it appear as the simple enunciation of those general facts with which by observation alone we have become acquainted," we will take a retrospective view of what has been advanced, and endeavour to deduce therefiom some general results as to the nature of those physical mutations, 
404 GEOLOGY OF TIIE ISLE OF WIGHT.

of which we have obtained such unequivocal proofs. Fortunately, the evidence of the important changes which the organic and inorganic kingdoms of nature have undergone in this part of the globe, during the vast periods embraced by our researches, is so conclusive, that the attentive reader will perceive the following inferences, startling as they may appear, naturally result from the facts that have been submitted to his observation.

I. Tine Oontric Epocm. - The most ancient deposits comprehended in our Excursions, are the uppermost beds of an oceanic formation of great extent-the Oolite-which is characterised by numerous peculiar species and genera of marine reptiles, fishes, mollusks, radiaria, corals, zoophytes, \&c. With these strata are intercalated in some places, deposits of variable extent and thickness, containing carbonized vegetable remains, and the stems and foliage of palms, arborescent and herbaceous íerms, cycadeous plants, and conifer'x ; with bones and teetlu of terrestrial reptiles, and of marsupial and insectivorous mammalia, issociated with vestiges of insects. 'These beds are evidently attributable to the action of rivers and streams, by which the spoils of the land were transported into the abyss of the ocean. But om present survey only refers to the period when a 
portion of the bed of the Oolitic sea was elevated above the waters, and eonstituted an islancl clothed with pine-forests, and cycadeous plants. *

II. The Wealden Erocir.-The country with its pine-forests was gradually submerged, and formed the beds of estuaries and bays, into which land floods, loaded with sedimentary detritus, deposited mud, silt, and sand, abounding in the remains of freshwater mollusks and crustaceans; in which, from occasional irruptions of the sea, were intercalated layers of oysters, and estuarine shells. Bones and teeth of terrestrial reptiles, and of river fishes, with stems and fragments of coniferous wood, were also drifted into the estuaries and bays by the streams and rivers. $\downarrow$ The gradual subsidence of the sea-bottom covered by these freshwater beds continued, and the sediments acquired an exclusively fluviatile character, till at length the accimulated deposits of a vast river formed an extensive delta, many hundred feet in thickness, upon the inferior strata. The imbedded organic remains attest, that throughout this epoch the fauna and flora of the country through which the river flowed, corresponded with those of the islands and continents of the Oolitic period.+

* Evidence: the lossil Forest of l'ortland, \&c. p. 395.

+ Evidenep: the Purbeck strata, p. 3.54.

\pm Evidence: the Wealden strata and fossils, 1. 332. 
III. Tine Cretaceous Epoch.-The commencement of this era was marked by the subsidence of the entire area now occupied by the greensand formation, to a depth sufficient to admit of the accumulation of the deep sea deposits, of which the greater part of the cretaceous beds of England, and of the adjacent portion of the European Continent, consists. The Wealden sediments were submerged to a great depth, and upon them were deposited sands, and argillaceous mud, and calcareous detritus, teeming with marine exuviæ.* But the ocean of the chalk extended far beyond the limits of the Weakclen; it buried beneath its waters a considerable portion of modern Europe, and its waves reached the New World, and covered part of the continent of North America. This ocean swarmed with numerous forms of marine organisms, belonging in a great measure to species and genera unknown in the earlier, and in the later, geological epochs. The interspersions of freshwater deposits containing terrestrial exurix, though inconsiderable, prove that although the delta of the country of the Iguanodon was submerged in the abyss of the ocean, a group of islands, or a continent, inhabited by that colossal reptile and its contemporaries, and covered with pinc-forests,

* Eirdence: Greensand strata at Atherfield, sic. see p. 223. 
cycadex, and ferns, flourished up to a late period of the Cretaceous epoch.*

IV. The Tertiary Epoch.-The bed of the chalk ocean was broken up, and considerable areas were elevated above the sea, and covered with vegetation, and tenanted by pachydermata and other mammalia ; the dry land of Europe during this period was less extensive than at the present time.

In the basins and depressions formed by the subinerged portions of the cretaceous strata, new sediments began to take place; the sea which deposited them teeming with marine animals, distinct from those of the pre-existing ocean. Local intrusions of freshwater deposits, abounding in the spoils of the land and its inhabitarts, denote the existence of islands or continents, tenanted by mammalia allied to the tapir, elephant, rhinoceros, horse, deer, \&c.; $\uparrow$ and the vegetable remains, consisting of palms and dicotyledonous trees, indicate an approach to the flora of the warm regions of the south of Europe. A few reptiles, principally of the alligator and crocodilian types, and lizards of small size, appear as the representatives of the

* Evidence: The Iguanodon, and freshwater turtles, pine-trees and cycadex of the greensand of Maidstone; the ferns of the greensand of the lsle of Wight, p. 230; the Clathraria Lyellii of the chalk-marl at Bonchurch, p. 244.

+ Evidenee: see p. 117, and p. 169. 
swarms of colossal oviparous quadrupeds of the previous epochs.

V. The Pre-historic Eросн.-From the most recent tertiary deposits, to those in which occur the remains of animals which seem to have always been contemporary with the human race, the transition is imperceptible. But elevatory movements, and subsidences, more or less general, appear to have continually taken place, by which the relative position of the land and sea was subjected to repeated oscillation. During this peric 1, large pachyderms, as the Mammoth, Mastodon, Hippopotamus, Rhinoceros, \&c.-several species of Horse-gigantic Elks and Deer-and many Carnivora, as the Lion, 'Tiger, Bear', Hyena, Scc. - inhabited the European Continent and Islands. While this fauma prevailed, a succession of terrestrial disturbances occurred, by which the physical configuration of the land was materially changed. England and its Islands were separated from the Continent; and to this epoch is probably refcrable the formation of the lines of elevation, that traverse the districts over which our observations liave extended.

Lastuy-Man took possession of the land, and such of the large mammalia as had survived the preceding geological revolutions, were either 
exterminated by his agency, or reduced to a domesticated state. Subsequently to the occupation of these Islands by the aboriginal tribes, the country has undergone no important physical mutations. The usual effects of the atmosphere, the wasting of the shores by the encroachments of the sea, the erosion of the land by streams and rivers, the silting up of valleys, and the formation of deltas, are apparently the only terrestrial changes to which England and its Islands have been subjected during the historic ages.

Corollary. - From this examination of the geological phenomena of the south-east of England, we learn that at a period incalculably remote, there existed in the northern hemisphere an extensive island or continent, possessing a climate of such a temperature, that its surface was covered with arborescent ferns, palms, cycader, and other coniferæ; and the ocean that watered its shores, was inhabited by turtles, and marine lizards of extinct genera. This country suffered a partial subsidence, which was effected so tranquilly, that many of the trees retained their erect position, and the cycadeous plants, and a considerable layer of the vegetable mould in which they grew, remained undisturbed. In this state an inundation of freshwater covered 
the country and its forests, and deposited upon the soil and around the trees a calcareous mud, which was gradually consolidated into limestone; thermal streams, holding flint in solution, percolated the mass, and silicified the submerged trees and plants.

A further subsidence took place, floods of freshwater overwhelmed the petrified forest, and heaped upon it accumulations of detritus, which streams and rivers had transported from the land. The comntry traversed by the rivers, like that of the submerged forest, enjoyed a tropical climate, and was clothed with palms, arborescent ferns, and cycader; it was tenanted by gigantic herbivorous and carnivorous reptiles, and its waters abounded in turtles, and various kinds of fishes, and mollusca. The bones of the reptiles, the teeth and scales of the fishes, the shells of the mollusca, and the stems, leaves, and sced-vessels of the trees and plants, were brought down by the streams, and imbedded in the mud of the delta, beneath which the petrified forest was now buried.

This state continued for an indefinite periodanother change took place-the Country of Reptiles with its inhabitants was swept away, and the delta, and the fossil trees with the marine strata on 
which they once grew, subsided to a great depth, and formed part of the bottom of a profound ocean; the waters of which teemed with countless myriads of zoophytes, shells, and fishes, of species long since extinct. Periodical intrusions of thermal streams charged with silex, gave rise to layers and veins of nodular and tabular flint, and occasioned the silicification of the organic remains subjected to their influence.

This epoch, which was of long duration, was succeeded by elevatory movements, by which the bottom of the deep was broken up, and large areas were slowly upheaved; and as the elevation continued, the deposits which had accumulated in the depths of the ocean, approached the surface, and were exposed to the action of the waves. These masses of cretaceous strata now began to suffer destruction, and the delta of the Country of the Iguanodon gradually emerged above the waters; and finally the petrified forest of the Oolite rose in the midst of the sea, and became dry land. At length some portions of the elevated strata attained an altitude of several hundred feet, and a group of islands was formed; but in the basins or depressions beneath the waters, sediments derived from the disintegration of the sea-cliffs were deposited. Large herbirorous 
mammalia now inhabited such portions of the former ocean-bed as were covered with vegetation sufficient for their support; and as these animals died, their bones became enveloped in the accumulations of mud and gravel, which were forming in the bays and estuaries.

This era also passed away-the elevatory movements continued-other masses of the bed of the chalk ocean, and of the wealden strata beneath, became dry land-and at length those more recent deposits containing the remains of the herbivorous mammalia which were the last tenants of the country. The oak, elm, ash, and other trees of modern Europe, now sprang up where the groves of palms and tree-ferns once flourished-the stag, boar, and horse, ranged over the plains in which were entombed the bones of the colossal reptilesand finally, Man appeared, and took possession of the soil.

At the present time, the deposits containing the remains of the mammoth and other extinct mammalia, are the sites of towns and villages, and support busy communities of the human race; the Huntsman courses, and the Shepherd tends his flocks on the elevated masses of the bottom of the ancient chalk ocean-the Farmer reaps his harvests upon the cultivated soil of the delta of 
the Country of the Iguanodon-and the Architeet obtains from beneath the petrified forest, the materials with which to construct his temples and his palaces: while from these various strata, the Geologist gathers together the relies of the beings that lived and died in periods of unfathomable antiquity, and of which the very types have long since been obliterated from the face of the earth, and by these natural memorials is enabled to determine the nature and succession of those physical revolutions, which preceded all history and tradition.

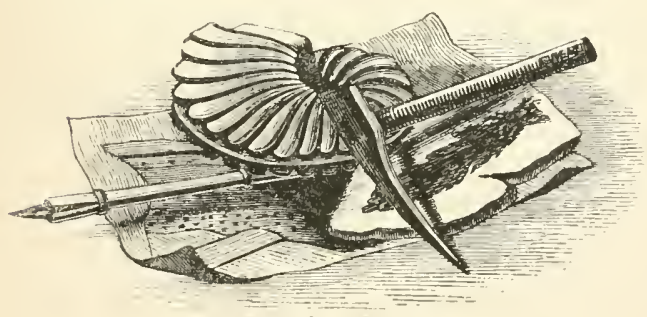




\section{ERRATA.}

Page 127 should be page 126.

"144, line 3 from the top, for west, read ast.

,220, tign. 18, N. and s. should be transposed : the left hand of the section is to the south. 


\section{A List af the most important Publications relating to the Geology of the Isle of Wight, and the Const of Dorsetshire.}

I. "A Description of the principal picturesque Beauties, Antiquities, and Geological Phenomena of the Isle of Wight; by Sir Henry C. Englefeld, Bart.: with additional observations on the Strata of the Island, and their continuation in the adjacent parts of Dorsetshire, by Thomas Webster, Esq. Illustrated by Maps, and numerous engravings from original drawings." 1 vol. folio. London, 1816. pp. 238, and 50 plates. Published at $\mathfrak{L} 4$ 4.s.*

The many references and extracts in the present work from this splendid volume, sufficiently attest its value. The Reader must bear in mind, that the fieshwater character of the "IroN SANDS" of Sussex, Kent, and Surrey, was unkuown to Mr. Webster at the period of Sir H. Englefield's publication; and that the series of deposits now denominated the Wealden, comprises the "Iron or ferruginous sands" below the clays and Sussex marbles, under the name of IIcstings sands: while the ferruginous sands between the Weald-clay and the Galt, belong to the Greensand group.

II. Dr. Fitrox's Memorr, to which reference has so often been made in the preceding pages, is published in Vol. IV. new series of the Transactions of the Geological Society of London; and

* Mr. Bohn has a copy for sale, price $£ 212 s .6 d$. 
may be purchased separately, as well as several of the following, at the Society's Apartments, Somerset House. It is entitled-

"Observations on some of the Strata between the Cifalk and the Oxford Oolite in the Sodth-east of England;" pp. 286, 5 eoloured Maps, 3 large plates of Sections, and 14 plates of Fossils. l'rice $\mathscr{L} 110 s$.

III. "ON the Geology of the Neighbourhood of Weysouth and the adjacent Parts of the Coast of Dorset." By the Rev. Dr. Buckland (now the Dean of Westminster), and Sir H. De la Beche. Geological Transactions, vol.iv. new series, pp. 46; with a large eoloured Map, and two plates of eoloured Sections. Price 78.

IV. "ON THE Discovery OF FOSSIl BONES OF THE IGUANOdON in the Wealden formation of the Isle of Wight aNd in the Iste of Purbeek. By the Rev. Dr. Buckland." Geol. Trans. vol. iii. pp. 8. One Plate. Priee $3 s .6 \ell$.

V. "Ineviries respecting the Geological Relations of the Beds between the Chalk and the Purbeck Lixestone in the South-east of Enguand. By Dr. Fitton." Annals of Philosophy for November, 1824.

VI. "ON the Purbeck and Portland Beds. By Thomas Webster, Esq. Secretary of the Geological Society." Geol. Trans. vol. ii. Seeond series, pp. 4. One plate of Fossils. Priee 2s. $6 d$.

VII. "On the Cycadeoidex, a Family of fossil Plan'ts found in the Quarries of the Isle of Portland. By the Rev. W. Buckland, D.D. \&c." Geol. Trans. vol. ii. Second series; pp. 8, with four plates. Price 5.

ViII. "Odthines of the Geology of England and Wales. By the Rev. W. D. Conybeare, and W. Phillips, Esq." I vol. Svo. London, 1822. This admirable work contains a compendium of the geological phenomena of the Isle of Wight and the adjacent coasts, so far as known at the period of its publication. 
IX. "Obserfations on Part of the Sections of the Luwler Greensand at Atherfield, on the Coast of the Isle of Wight. By W. H. Fitton, M.D. \&c." Proceedings of the Geological Society, vol. iv. p. 198.

$\mathrm{X}$. "On the Thichness of the Lower Greensand Beds of the South-east of the Isle of Wight. By F. W. Simms, Esq." Quarterly Journal of the Geological Society, vol. i. p. 76 .

XI. "Comparative Remaris on the Sections below the Chalk on the Coast near Hrthe in Kext, and Atherfield in the Isle of Wight. By Dr. Fitton." Quarterly Journal of the Geological Society, vol. i. p. 179.

XII. "On the Section between Blackgang Chine and Atherfield Point. By Capt. L. L. B. Ibbetson and Professor Edward Forbes." Quarterly Journal of the Geological Society, vol. i. p. 190.

Xili. "Catalogue of Lower Greensand Fossils in the Musedm of the Geological Society. By Professor Edward Forbes, F.R.S. \&c." Quarterly Jonrnal of the Geological Society, vol. i. p. 237 , and p. 345 .

The following Memoirs principally relate to the Strata above the Chalk.

I. "On the Freshwater Formations in the Isle of Wight, with some Observations on the Strata ovek the Cilalo in the South-east Part of England. By Thomas Webster, Esq." Geol. Trans. rol. ii. (published in 1814).

II. "On the Freshwater Formation in Hordwell Chiff, HaMPSHIRE, AND ON THE SURJACENT BeIs frod HoRdWELl to Muddiford. By Thomas Webster, Esq." Geological Transactions, vol. i, p. 90. Second series. 
III. IV. "On the Strata of the Plastic Clay Formatgon exhibited in the Cliffs between Christchurch Head iN Hampshire and Studiand Bay in Dorsetshire." And “ON the Freshifater Strata of Hordwell Chiff, Beacon Cliff, and Barton Cliff, Hampshire. By Charles Lyell, Esq. F.R.S. \&c." Geological Transactions, vol. ii. Second series. Pp. 14, with a coloured Map. Price $7 s$.

V. "On the London and Plastic Clat Fohmations of the IsLe of Wight. By J. S. Bowerbank, Esq. F.R.S.” Geological Transactions, vol. vi. pp. 4. Woodcuts. Price 1s. $6 d$.

VI. " Remaris on the Existence of Anoplotherium and Paleotherium in the Fresinwater Strata at Binstead, near Rrde, in the Isle of Wight. By Samuel Peace Pratt, Esq. F.R.S." Geological Transactions, vol. iii. pp. 3. Price $3 s$.

VII. "Description of some Fossil Remains of Charopotamus, Paleutherium, Anoplotilerium, and Diohobune, from the Eooene Formation, Isle of Wight. By Professor Owen." Geologieal Transactions, vol. vi. pp. 19 ; two plates. Price $7 s$.

VIII. "ON tile Tertiary or Supra-cretaceods Formations of the Isle of Wight, as extibited in the Sections at Alum and Whiteclifr Bays. By Joseph Prestwich, Jun. Esq." Quarterly Journal of the Geological Socicty, vol. ii. pp. 224-259.

IX. "On the Discovery of tile Fossil Remains of an Alli-

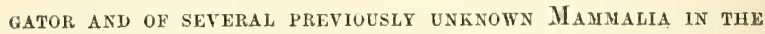
Iordwell Cliff; with Observations upon tire Geological Phenomena of that Locality. By Mr. Searles Wood, F.Cx.S." In "The London Geological Journal, and Record of Discoveries in British and Foreign Palwontology," p. 1. September, 1846. Published every second month, by Churchill, London.

* * Models of the Isle of Wight, coloured geologically (price from $5 s$. to $2 l .2 s$.), may le obtained of Mr. R. T. Wilde, 19, Cursitor-street, Chancery-lane. The purchaser should order the model to be coloured in accordance with the Gcological Map of this volume. 


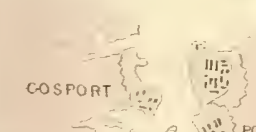

- 3 PORTSMOUTH
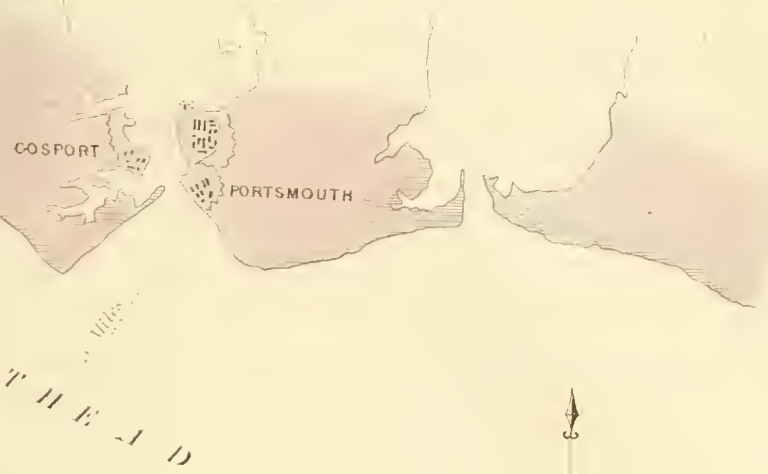

$d$

YDE

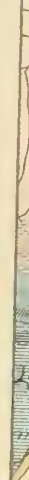

.

$\rightarrow$
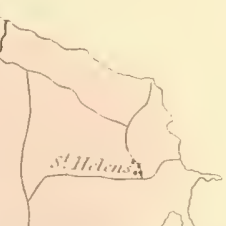

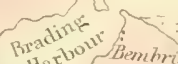

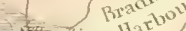

\section{Bं}

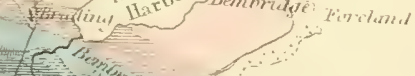

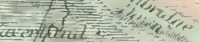

Thank $\angle 7 i t i$ is iuline itiir

rijis

S. $1-1 D$ H 11

B -1

hitin itrine

$n+3$,

'm: 7 rims

Hewnl
Liscese deposits

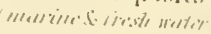

INDEX OF COLORS

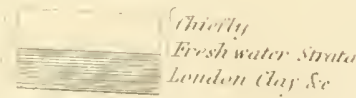

Firsh water inve beriederll ities ife

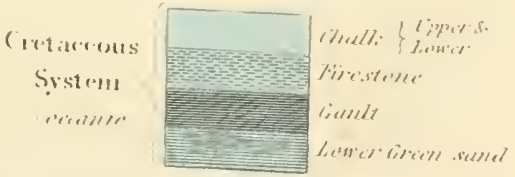

IIrallde.1s

'iles melile.

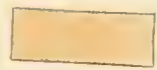

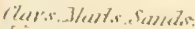
limeserenes. 


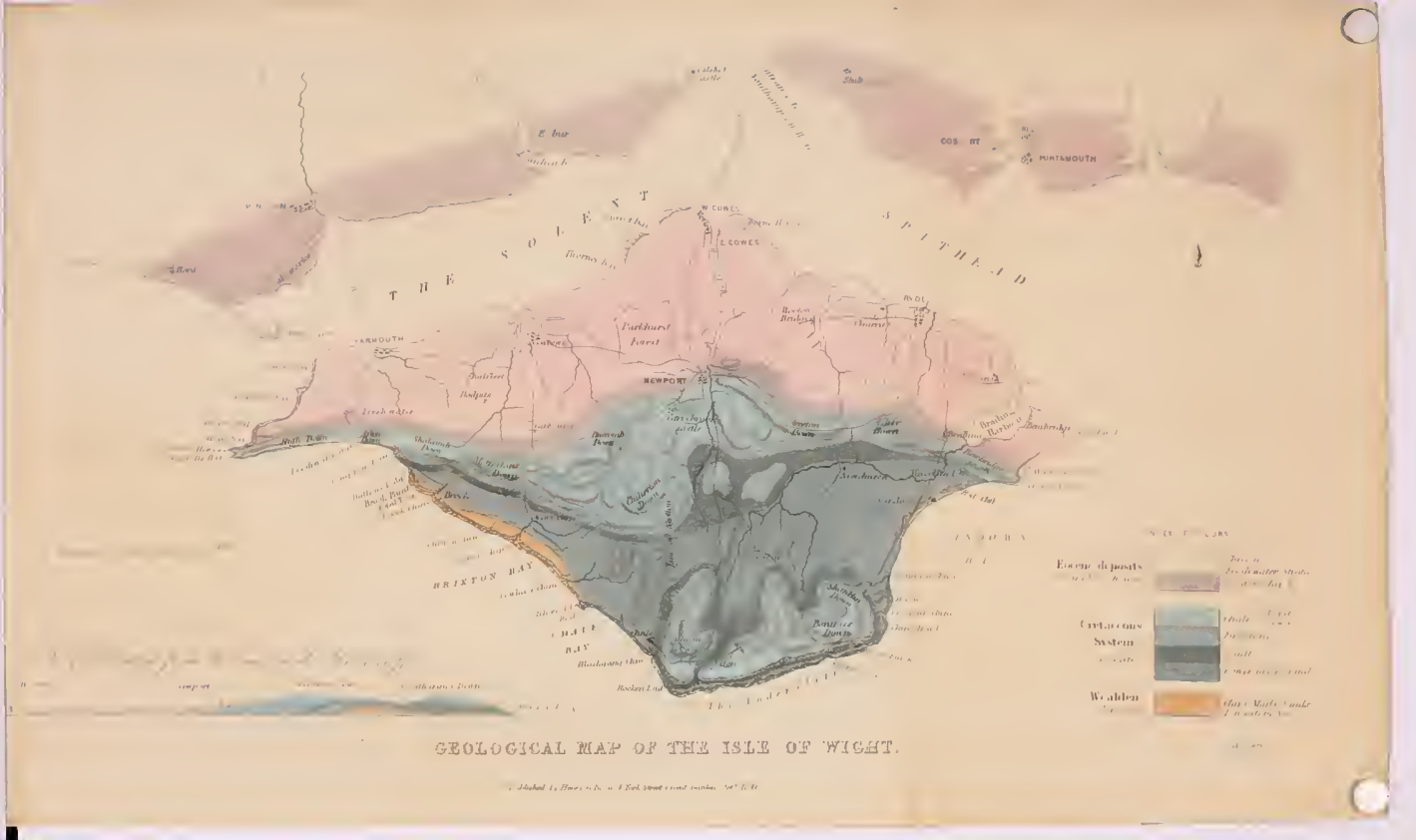




\section{INDEX OF PLACES.}

A.

Afton Dowss, 25, 204, 206.

Alum Bay, 24, 149, 155.

Arish-mel, 376.

Arreton Down, 205.

Ashey Down, 122, 205.

Atherfield Cliffs, 221, 230, 342 .

Station, $20,220$.

B.

Bagshot, 85 .

Ballard Downs, 369 .

Barn-door Cove, 386.

Barton Cliff, 166.

Basingstoke, 85.

Bats-corner, 369, 386, 389.

Beacon Cliff, 166.

Bembridge, 123. Foreland, 336.

Binstead, 18, 102.

Blackgang Chine, 26, 233, 249, 341 .

Bognor, 127.

Boncliurch, 247, 25], 257.

Bournemouth, 169 .

Bracklesham Bay, 129.

Brading, 122.

\section{Down, 26, 251.}

Haven, 96, 336 .

Brighton, 203.

Brixton Bay, 284, 328.

Brook, 2 i9.

Bay, 271.

Point, 25, 277.

Bullface Ledge, 277.

c.

Calbourne, 143.

Calshot Castle, 89.

Carisbrook, $1+2$.

Chaldon Downs, 369, 389.

Chapman's Pool, 366.

Cherton Bunny, 166.

Chesil Bank, 391, 393.

Chesilton, 401 .

Christchurch Bay, 164.
Colin's Pool, 256.

Colwell Bay, 149 .

Compton Bay, 25, 27, 210, 214, 280. Chine, 210, 373.

Cowes, 18, 97, 146 .

Cowlease Chine, 285.

Culver Cliffs, 27, 125, 339.

D.

Dodspit Farm, 143 .

Dorsetshire Coast, 28.

Dunnose Poiut 250, 257, 340 .

Durdle Cove, $29,385$.

Durlstone Bay, 352 .

Head, 363.

E.

Emmett's Hill, 366 .

Esher, 84

F.

Freshwater Gate, 19, 24, 194.

G.

Gad Cliff, 366.

Goldsworth Hill, 84.

Gosport, 88 .

Gurnet Bay, 146.

11.

Hampstead Cliff, 146 .

Handfast Point, 214, 349.

Headon Hill, 24, 14y, 158 .

Hengistbury Head, 164.

High Down, 177.

Holworth Cliff, 392.

Hordwell, 164, 171.

Horse-shoe Bay, 255.

Horsham, 327 .

Hurst Castle, 165.

1 sle of Portland, 393. Purbeck, 345

Wight, so. 
K.

Kimmerioge Bay, 366 .

L.

Ladder Chine, 231.

Littie-town Down, 256,

Longmead End, 165.

Juecomb Chine, 258.

Lulworth Cove, $28,376$.

_ Last and West, 376.

Lymington, 163.

\section{M.}

Main-bench, 198

Man-of-war Cove, 386.

Medina River, 95, 140.

Motteston Downs, 204.

Mountjoy Down, 140.

Ni upe Cove, 386.

\section{N.}

Needles, The, 24, 198, 343 . Down, 205.

Newchureh, Vale of, 261.

Newport, 139, 142.

Newtown Bay, 96, 146.

Niton, 241.

o.

Osborne, 145 .

Osmington Cliff, 393, 401.

P.

Parkhurst Barracks, 140.

Portland, Isle of, 393.

Purbeck, Isle of, 345 .

Q.

Quarr Abbey, 103.

\section{R.}

Redcliff, 135, 334.

Ringstead Bay, 390, 40I.

Rookley, 142.

Ryde, 18, 98 .

S.

Saint Adhelm's IIead, 365 .

Boniface Down, 250.

Catherine s Down, 240, 2J9.

- Clare, 23li.

I1elen's, 114, 124, 336.

Sandown T3ay, 132, 261, 339.

Sandrock, 237.

Schehallien, 251.
Seratchell's Bay, 198.

seafield, 117.

Shalcomb Down, 219, 343.

shalfleet, 142 .

shanklin, 258.

Chine, 258.

Down, 251, 257.

shepherd's Chine, 285.

Southamytor, 86 .

Spithead, 90 .

stare Cove, 386.

Stone, Bucks, 400.

Stubbington, $\$ 9$.

studland Bay, 349 .

s'wanage, 346.

- Bay, 348.

Swindon, 399.

Swine's Back, 369.

T.

Thame, 399.

Thorney Bay, 146.

Tiepit, 285.

Tillywhim Quarries, 363.

Tolland's Bay, 149.

Tongariro, 181.

U.

Undercliff, 93, 237, 251.

V.

Vauxhall Station, 17.

Ventnor, 248, 255.

Shute, 250.

พ.

Walpen Chine, 231.

Wandsworth Station, 83 .

Wardour, Vale of, 399 .

West Iulworth, 29, 376 .

Weybridge station, 84.

Wevmouth, 391, 101 .

Whale Chine, 231 .

Whitecliff Bay, 124, 339.

Whitenore Point, $390,40 \mathrm{l}$.

Winchester, 86 .

Windspit Quarries, 361 .

Winglield Station, 8.5 .

Woking Common, 84.

Woot on-bridge, 19, 139,

- river, 96.

Worbarrow Bay, 28, 370, 375. Knob, 367.

Y.

Yar, hiver, 96.

Yarmouth, 19, 162, 19.1, 345.

Yaverland, 123, 311. 


\section{GENERAL INDEX.}

A.

Afton Down, views from, 25, 206. Alligator, fossil remains of, 169 . - Hantoniensis, 169

Alum Bay, View of, 24,147 .

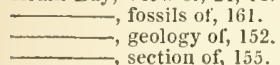

Ammonites giganteus, 400 Mantelli, 187. varians, Is7.

Animalcules, fossil in flint, 184 .

-

Anoplotherium commune, 117, 118 .

118.

Anticlinal axis of Sandown Bay, 135.

Araucaria excelsa, 398 .

Arca raulini, 191.

Artesian wells, 81, 87

well of Grenelle, 82.

Ashey Down, 122.

sea-mark, view from, 205.

Atherfield Cliffs, 221.

fossils, 225, 239.

225,227 . greensand series, 223, road to, 220 .

Station, 20, 22I.

342.

B.

Bagshot sands, 78.

Bar of shingle off Hurst Castle, 165.

Barber's Isle of Wight, 17.

Barn-1loor Cove, 386.

Basingstoke, 85 .

85.

Bats-corner, 390 .
Bembridge, 124.

Binstead, 18, 105 .

fossils, $103,107,110$.

, limestone, 107.

quarries, 102.

Blackgang Chine, view of, $26,233$.

-

Bognor rocks, 127 . from the sea, 311 .

Bog-wood, 273.

Bonchurch, 245. , fossils from, 245 .

Bones of reptiles, 137, 312, 355 . in firestone, 245.

Botanic Garden, fossi] trees in, 397.

Bowerbank, J. S. Esq., on Alum Bay, 13.

Bay, 132 .

Brackleshàm fossils, 129.

Brading Church, 122.

26,252 .

Down, vertical strata on, Haven, 96.

Brander's Hampshire fossils, 164.

Brannon's Map of the Isle of Wight, 17.

British Museum, fossils in, 356, 398 .

Brodie, Rev. P. B., on Fossil Insects, 400.

Brongniart, Ad. M., on Fossil Plants, $257,397$.

Brook Bay, Excursion to, 271.

Point, view of, $25,277,3\{2$. to Shaicumb, 220. from the sea, 342 .

Brown, Dr. Robt., on Fossil Plants. 290, 398.

Buckland, Rev. Dr. (Dean of Westminster) Bridgewater Essay, 323, 330.

Weymouth, 38I.

on Geology of

Wells, 82. 
Buck land, Rev.Dr. on fossil Cycadea, 398.

$137,311,323$.

Bulimus, fossil, 111 .

Bullface Ledge, 274, 277.

Butler, Mr., of Yarmoutlı, 19.

C.

Calbourne, 142 .

-_ to Alum Bay, 143.

Calshot Castle, 89.

fossil shells, $1+2$

Cardita planicosta, 128.

Carisbrook, 142.

Carr, Henry, Esq., fossil wood in chalk, 193.

Cave in chalk cliff, 197.

Cerithium turriculatum, 191.

Cetiosaurus, 324.

Chæropotamus, $117,119$.

Chalk cliffs at Freshwater-gate, 24, 195.

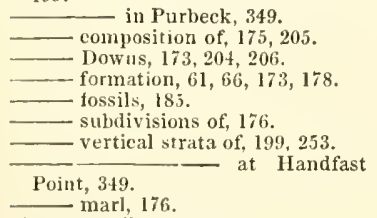

Charæ, fossil, 108, 130.

Chert of the Undereliff, 211.

Chesil-bank, 39l, 393.

Chesilton, 401.

Chilley pitch-stone, 368 .

Choanites, 216.

Christchureh Bay, 164.

Clark, sir James, on Climate, 238.

Clathraria Lyellii. 244, 292.

lbbe'son, 295.

Cliffs at Alum Bay, 155 .

— at Blackgang Chine, 233.

— in Compton Bay, 272, 274.

- Culver, 27, 125, 339.

Climate of the Undercliff, 238.

Coal, Kimmeridge, 367 .

Coast, eastern, Isle of Wight, 124.

, northern, Jsle of Wight, 89, 145.

, sorthern, Isle of Wight, 213, - western, lsle of Wirht, 155. of the Underclitr, 251. - Hanpshire, 163.
Coast of the Is!e of Purbeck, 318. 370.

Colby, Col, on the Plumb-line, 251.

Colwell Bay, 149.

Compton Bay, 25, 27, 214, 274, 343 .

Chine, 273.

Coniterous fossil wood, 252.

Contorted strata, 363.

Conybeare, Rev.W. D., on Handfast Point, 350.

in Purbeck, 374.

Corbis corrigata, 190.

Corollary, 409

Country of the Iguanodon, 332 .

Coves of Dorsetshire, 28, 29, 369, 376.

Cowes, 18, 97, 146.

Crackers rocks, 225.

Cretaceous system, 175, 192.

Crocodile, fossil, 163.

C of Swanage, 355.

"Crows' Nests," 398.

Culver Cliffs, 27, 125.

Cycadeous plants, 291

fcssil, $288,395$.

Cyprides, fossil, 111, 136, 305, 307

Cytherea incrassata, 149.

D.

Damon, Mr., fossils collected by, 401 .

Dotes by, 401 .

Dean of Westminster. See Dr. Buckland.

De la Heche, Sir Henry, on the Geology of Weymouth, 384.

Description of the plates, 23.

Dichobune cervinum, 117, 119.

Dinkel, Mr. Joseph, drawings by, 295.

Dirt-bed of the Isle of Portland, 395.

- in Lulworth Cliff, 384.

Ditrupa plana, 128.

Dodspit, fossils at, 143 .

Jorsetshire Coast, view of, 28.

Dowus, Afton, 204, 206. Coves o11, 28, 374

- St. Boniface, 250. Catherine, 240.

Chaldon, 369, 389.

- Needles, 205.

- southern range of, 219 .

Drift, or alluvium, 60 .

Dunnose Foint, 257.

Durrlle Cove, 29,385 
Durlstone Bay, 351.

Head, 352

oolite of, 363.

E.

Endogenites erosa, 288.

Euglefield, Sir Henry, work on the Isle of Wight, 98.

$165,199,202,258$. quoted, 149 ,

Esher, strata at, 84.

Excursion to Atherfield, 218. Brook Bay, 271.

Atherfield, 220. from Compton Bay to to Christchurch Bay, 164.

F.

Fault in Ringstead Bay, 39].

Femur of Iguanodon, 314.

unkuown reptile, 245.

Ferruginous sand-cliffs, 341 .

Firestone strata, 176, 185, 241, 242.

Fishes, fossil, 307.

Fissures, or joints, in chalk, 200.

Fition, Dr. on the Atherfield strata, 222,228 .

Portland strata, 390.

351 .

Wealden, 270, 289,

Worbarrow Bay, 375 .

380 .

Flint, formation of, 179 .

- layers and nodules, 180.

— veins, 200.

- shattered, 202, 350 .

Footsteps, supposed, 247.

Forbes, Prof. E. quoted, 131, 223, 227.

Forest, petrified, of Portland, 395 .

Fossil alligator, 172.

- animalcules, 183.

crocodile of Lymington, 163.

__ fishes, 2 ¿2, 307.

fuci, 249 .

lobsters, 232.

- mammalia, 115.

— reptiles, $245,309$.

- sponges, 183.

- turtles, 326, 358.

Fossils, cretaceous, 181.

- of Alum Bay, 161.

Barton, 172.

Hordwell, 171.
Fossils, vegetable, 108, 161, 244, 247 .

- - of the eocene strata, 110,161 .

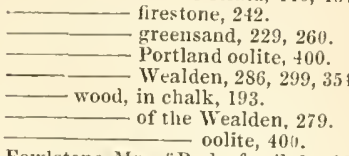

Fowlstone, Mr. of Ryde, fossils by, 18.

wood, 218.

Fox, Rev. W. D. fossils found by, 117.

Freshwater eocene strata, 100, 1f6.

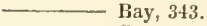

- Gate, cave at, 197.

Fuci, fossil, 247 cliffs at, 19, 24, 195 .

G.

Gad Cliff, 366 .

Galt, 176. of the Undercliff, 240.

Geology of Alum Bay, 153, 159.

Brook Bay, 272.

Compton Bay, 210.

Headon Hill, 158.

Hordwell Cliff, 166.

Isle of Wight, 90 .

Portland, 393.

Purbeck, 361 .

Sandown Bay, 132.

the S. E. of England, 69. Whitechff Bay, 124.

Geological mutations, 74. principles, 56 .

Gervillia anceps, 190.

Gladstone, Messrs. fossils collected by, 230 .

by, 20 . geological tour

Glauconite, 176.

Goldsworth Hill, 84.

Goniopholis, 357.

Gospert Railway, 88 .

Greens:Ind, 176, 189, 223.

Upper, or Firestone, 185. - fossils, 190,229 .

stitution, 229.

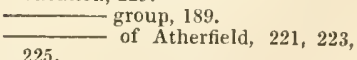

225. Neufchatel, 227.

Grenelle, Artesian well of, 82 . 
Grey Wethers, 80, Grove's Hotel, 144. Gryphea sinuata, 191, 231.

Gurnet Bay, 146.

Gyrogonites, 109.

H.

Hampstead Cliffs, 146.

Handfast Point, 349 . , vertical strata of, 350 .

Hastings, Geology of, by Dr. Fitton, 269. sands, 351 .

Headon Hill, 24, 161 .

\begin{tabular}{l}
$\square-$ fossils of, 161. \\
- strata of, 158 . \\
\hline
\end{tabular}

151.

Hengisbury Head, 164.

Ilopkins, -, Esq. on Geological Structure, 141, 392.

Hordwell, 164. Cliffs, 166.

—_ fossils of, 169,171 . strata of, 166.

II urst Castle, 165.

Hlybodus fossil, 232 .

Hylæosaurus, 322.

I.

Ibbetson, Capt. Clathraria discovered by, 295 .

$229,232 . \quad$ fossils collected by,
223.

Wight, by, vi.

Iguanodon, 312, 321 .

bones of, found in Sandown Bay, 137.

355.

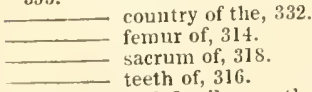

inpressions of fossils, method ot taking, 328.

Imprints on sandstone, 326,328 .

Insects, fossil, 140 . of the Wealden, 400 .

400.
I ron-sand of Mr. Webster, 189.

1sle of Portland, 393.

395. petrified forest of,

Purbeck, 345.

Vight, cretaceous fossils of,

185.

\begin{tabular}{l} 
eocene, 108.127. \\
\hline form of, 91. \\
geological structure
\end{tabular}

190.

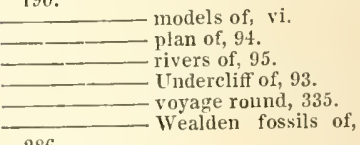

286.

Itchin, river, 86 .

J.

Jasper pebbles, 217

K.

K immeridge Bay, 366.

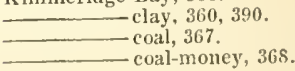

L.

Lepidotus, 307 .

Lignite in greensand, 323 .

Limneus, 111. wealden, 284.

Lobster, fossil, 232.

bed of, 225 . 230.

- Mantelli, 288.

London and Brighton railway, 72 .

London basin, 60, 78 .

clay, 80. eocene formation, 66 .

Long-mead End, 165.

Long-stone, 220.

Luecomb Cline, 256.

Lulworth Cove, 376. strata of, 379 view of, 28 . 
Lyell, Charles, Esq., on Compton Bay, 280.

$\frac{\text { shire coast, 167. }}{\text { sissippi, 269. }}$ the Hamp-
Bay, 280.
Bay, 126, 130, 146.
Lymington, fossils from, 163.

N1.

Mammalia, fossil, 24, 115, 117. 169.

Mantelliæ, 398.

Map, geological, of the lsle of Wight, $30,92,430$.

Meadow-rue, fossil, 140.

Medina river, 9.5, 140.

Megalosaurus, 323.

Mineral spring at Sandrock, 237.

Mississippi, delta of, 269.

Molluskite, 248.

Morris, John, Esq., fossils discovered by, $230,2 \pi 4$.

Mountjay Downs, 140.

Murchison, Sir R., on the deviation of the plumb-line, 251 .

strata, 241.

firestone

ampton well, 88 .

South-

Mussel-shells, fossil, of the Wealden, 302.

N,

Natica rotundata, 190.

Nautilus elegans, 186.

Needles, the, 198, 343.

Neocomian strata, 227.

Neritina concava, 149 .

Neufchatel, greensand of, 227 .

Newchurch Vale, 261.

Newport, 139.

- to Calbourne, 142.

Newtewn Bay, 96, 146.

Nodules of flint, 180

Northampton, the Marquess of, fos. sils discovered by, 183.

Nucula scapha, 191 .

Nummulites, 129. o.

Oolite, meaning of, 359 . Portland, 359 .

Order of superposition of the strata. 65.

Organic remains of the chalk, 1 \$.

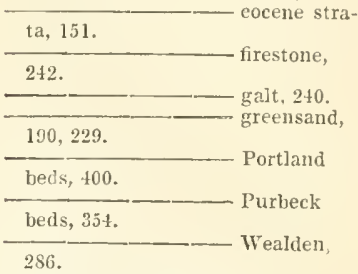

Osborne, strata on the coast of, 145 .

Osmington Cliff, 393.

Owen, Professor, British mammals by, 117 .

reptiles, 318.

Oxford clay, 393

- oolite, 367,391 .

Oyster-shells, fossil, in Purbeck strata, 224,354 .

strata, $1 \leq 9,149,158$. tertiary

\section{P.}

Palæontological Journal, 171, 418.

Palæotherium crassum, 117.

- magnum, 117. medium, 117,119 . minus, 117. - from Hordwell, 170.

Paludina, fossil, of the Wealden. 300.

Panopæa intermedia, 128.

Parkhurst barracks, well at, 140 .

Pebbles, 18, 216.

Pedestrian tour round the lsle of Wight, 20

Perna mulleti, 191.

Petrified forest, 395.

- trees, 279 . wood, 282.

Petworth marble, 299.

Phillips, John, Professor, plan of the Geology of the 1sle of Wight, 94.

Planorbis, fossil, 111.

Plesiosaurus, 325.

Polytechnic Institution, models and fossils in, 188, 229, 232, 245. 
Portland, Isle of, 394.

\begin{tabular}{|c|c|}
\hline & $\begin{array}{l}\text { limestone, } 360 \text {. } \\
\text { oolite, } 359 \text {. }\end{array}$ \\
\hline & $\begin{array}{l}\text { petrified forest of, } 395 \text {. } \\
\text { quarries, } 396 .\end{array}$ \\
\hline
\end{tabular}

Potamides of the Wealden, 224, 301 .

Pratt, S. P. Esq., fossils discovered by, 116.

Prestwich, J. Esq., on Alum Bay, $154,159$.

Bay, 126.

Pristis (saw-fish) fossil, 84 .

Pritchard, Rev. Charles, fossils by, 310.

Pseudo-rolcano, 394.

Pterocera retusa, 191.

Purbeck, Isle of, 345,361 .

- fussils of, 354 .

_- marhle, 353 .

$$
\text { views in, } 28 .
$$

Pyrites, 278.

\section{Q.}

Quarr abbey, ruins of, 103.

Quarries at Binstead, 102. Portland, 395.

Purbeck, 354.

- Tillywhim, 363.

Windspit, 364 .

R.

Raft, fossil, in Brook Bay, 279.

Railway sections, 83 .

Range of the 1sle of Wight chalk hills, 176 .

Red-cliff, 135.

Rein-deer, fossil, 103.

Reptiles, fossil remains of, $245,309$. femur of, 245.

__

Retrospect, 403.

Richmond, Rev. Legh, quoted, 122, 123, 205.

Ringstead Bay, 390.

River Medina, 140.

Rivers, nature of deposits, 264. of the Isle of Wight, 95 .

Wealden, 332.

"Roach," limestone so called, 402.

Rock, arched, in Durdle Cove, 386.

Rock-crystal pebbles, 217.

Rostellaria robaldina, 191 .
Rotaliæ, fossil, 184 .

Ryde, 18, 98 . soft parts of, 184.

quarries near, 102.

- seashore of, 98 .

to Alum Bay, 145.

Culver Cliff, 121.

Newport, 139.

\section{S.}

Sacrum of the Iguanodon, 318.

St. Adhelm's-Head, 365 .

St. Boniface's Down, 250. well, 250.

St. Catherine's Down, 240.

St. Cross, hospital of, 86 .

St. Lawrence's church, 252.

Sandown Bay, 132, 261, 339. section of, 134 .

Sandrock mineral spring, 237.

Sandstone, riplled, 326 .

326.

Saw-fish, fossil teeth of, 84 .

Saxby, J. M. Esq., fossils by, 188, 255.

Scaphites grandis, 19, 231.

Schehallien, mountain of, 251,

Scratchell's Bay, 198.

Sections, geological, from Alum Bay to Headon Hill, 155 .

Shalcomb, 220. Brook to
Brighton, 72.

the Isle of Wight, 71, 75 . of Chaldon

Downs, 390. Compton Bay,

213.

385.

Cove, 376. Lulworth

134.

126.

\begin{tabular}{l} 
Bay, 375. \\
coast, by Mr. Lyell, 168 . \\
coast of the Isle of Wight, 213. \\
\hline
\end{tabular}

256.

Sedgwick, Professor, quoted, 103.

Septaria, 402. 
Shakcontb Down, 220.

Shalleet, fossils from, 112.

Shanklin, 258.

Chine, 258.
- Down, 251.
Shark, fossil skull of, $\mathbf{2 3 2}$.

Shark, fossil skull of, 232 .

Shattered flints, 202, 251, 850 .

Shel!s, fossil, of the cretaceous strata, 185.

\begin{tabular}{l} 
strata, 24, 110. \\
ta, 24, 161. \\
\hline \\
\hline 400. \\
\hline 353.
\end{tabular}

Shingle, pebbles composing it, 216 .

Silicified chalk fossils, 186.

Siphonia, 230, 243.

Smart, W. Esq., fossils from Bournemouth, by, 169.

Smith, Rev. Gerard, fossils by, 311.

Soft parts of animalcules in chalk, 184.

Soulhampton Artesian wells, 87.

- station, 86.
- to Ryde, 89.
water, 89.

South-Fast of England, Geology of, $59,69$.

Southern coast of the Isle of Wight, seetions of, 213.

South-west coast of Dorsetshire, 368.

South-western railway, 77 .

Steamers to the Isle of Wight, 89. Lymington, 163. Swanage, 346.

steam-voyage round the 1 , of Wight, 335.

Stonesfield fossils, 359 .

Strata, arrangement of, 63 .

- chalk, vertical, 199.

Streptospondylus, 325.

Stutchbury, Mr. ITenry, deaier in fossils, 401 .

Subsidences of the Underclift, 252.

Sugar-candy spar, 395.

Summary of the geological phenomena of the Wealden, 331.

Superposition of tle strata, 6.5.

Surrey, geology of, 78,83 .

Sussex marble, $2+9$.

Swanage Bay, $348,352,363$. fossil crocodile, 355 .
T.

Tabular arrangement of the stratit, 63.

Teeth, fossil, of Goniopholis, 357.

Hybodus, 232.

Tennant, Mr., fossils of, 400 .

Terebratulæ, 226.

Terebratula selta, 191.

Terrain Néocomien, 228.

Tertiary strata, 60.

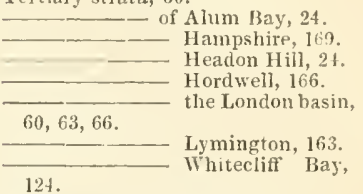

Thalietrum, fossil, 140.

Thetis minor, 19I.

Tilgate Forest, fossils of, 269 .

Tillywhin quarries, 363 .

Tolland's, or Totness Bay, 149.

Tongariro, mountain of, 181 .

Topping, Mr., microscopical artist, 184.

Tornatella albensis, 191.

Tour of the Isle of Wight, 20.

Trees, fossil, in Brook Bay, 279.

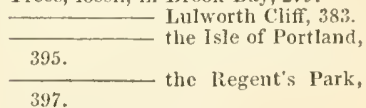

Trigonia caudata, 190.

Trionyx Bakewelli, 326.

$\longrightarrow$ fossil, 112,114 .

- of IIordwell, 169. the Wealden, 326.

Trotter, Robert, Esq., fossil reptile found by, 355 .

Turtle, fossil, of Binstead, 112.

Purbeck, 35s.

- St. Helen's, 11t.

the Vealden, 326.

U.

Undercliff, the, $237,340$.

- coast of, 251.

geology of, 240 .

Unio l'aldensis, 302.

V.

Valley of the Mredina, 141.

Variegated strata of Alum Bay, 157.

Vauxhall station, 77 . 
Ventnor, fossils from, 255.

- Shute, fossils from, 250.

stiata around, 255 ,

to Sandown Bay, 257.

Venus parva, 191. - striato-costata, 191.

Vertical elaalk strata, 199. at Ilandfast Point, 349. - - the Needles, 155.

on Brading Down, 251

Vine, J. Esq., fossils found by, 311.

Voyage from Yarmouth to Swanage, 345 .

round the Isle of Wight, 335 .

W.

Wealden clay of Atherficld, 224.

\begin{tabular}{l} 
- cyprides, 305. \\
- fishes, 307. \\
\hline formation, $62,68,262$.
\end{tabular}

cyprides, 305.
- fishes, 307.
formation, $62,68,262$.

- character of, 268.

Purbeck, 353. of the Isle of

Wight, 269.

Bay, 136.

\section{Sandown} Sussex, 267.

\section{fossils of, 286.288.}

reptiles of, 309 .

shells, 299.

unionidæ, 302.

Webber, Mrs. Jane, of Earton, dealer in Hordwell fossils, 172 .

Webster, Thos. Esq., on the Geology of the Isle of Wight, 127, 140, 145, $154,157$.

279.
shire coast, 346. the Dook Point,

\begin{tabular}{l} 
tered, 204. \\
strata, 368. \\
\hline land, 394. \\
Pobbles, 217. \\
strata, 354. Purbeck \\
\hline 243.
\end{tabular}

Wells, $83,87,90$.

at Southampton, 87.

West Lulworth, 29 .

Weyb:idge, 84 .

Weymouth, memoir on the geology of, 384 .

401.

Whitecliff Bay, 124.

Forbes, Prof. on, 131.

126. Prestwich, Mr., ol, section of, 126 .

Whitenore chalk cliffs, 390 .

Winchester station, 85 .

Windspit quarries, 304 .

Wingfield station, 86.

Woking Cummon, 84 .

Wood, Searles. Esq., on Hordwell Cliff, $115,167,169$.

Wood, coniferous fossil, 252.

__ in chalk, 193. of Portland, 395.

Woodward, Professor, drawings by, 30.

Wooton-bridge, 19. river, 96.

Worbarrow Bay, 28, 370, 375.

Y.

Yar, river, $1 ! 4$.

Yarmouth, 19, 163.

- to Freshwater Gate, 194.

- Hordwell, 164.

- Lymington, 162.

Yaverland, 123.

$Z$.

Zamia, fossil, 138, 291.

- crassa, 138.

Zoophytes of the chalk, $18 \%$. 
1. THE FOSSILS OF THE SOLTH DOWNS; or, Illustrations of the Geology of Sussex. 1 rol. royal 4to, with 42 Plates, containing several hundred figures of Fossils; Map, \&c. (London, 1822).-Mr. Bohn has a copy of this Work; $2 l .2 s$.

II. THE FOSSILS OF TILGATE FOREST; or, Illustrations of the Geology of the South-East of England. 1 rol. royal 4to, with a Map, Sections, and 20 Plates, comprising nearly 200 figures of Wealden fossils. (London, 1827). Out of print.

III. THE GEOLOGY OF THE SOLTH-EAST OF ENGLAND. 1 vol. 8vo, with Map, Plates, and numerous Figures. Price 17. 1s. (Ptiblished by Messi's. Longman, of whom a copy may be obtained.)

"The straitness of our limits prevents us from indulging in any quotations from this original and scientific work, which is distinguisbed by a correctness of arrangement, an accuracy of description, an acuteness of deduction, a comprehensiveness of theory, a perspicuity of style, and an excellence of graphic illustration, which reflect infinite credit upon the zeal and industry of the author, who, though most extensively engaged in the practice of his profession, has devoted his leisure to such noble purposes as the researches commemorated in this book. The successful handling of such subjects requires an exact and extensive knowledge of chemistry, and comparative and human anat $m y$, and botany, and a general arquaintance with all the natural sciences; this knowledge is possessed in a high degree by Dr. Mantell, whose numerous discoveries in fossil botany and anatomy not ouly evince the solidity of lis knowledge, but place in a strong light his industry, perseverance, and patience, in overcoming the difficulties and evading the obstacles which the pursuit of his arduous profession presents. Dr. Mantell affords an example worthy the imitation of all lis medical brethren, and furnishes a signal proof that active professional occupation, is not incompatible with a deep devotion to the most profound philosophical investigations which can engage the mind of man."-Lancet, March, 1834 .

IV. THE WONDERS OF GEOLOGY; or, A Familiar Exposition of Geological Phenomena. In 2 vols, foolseap 8vo, with coloured Plates and numerous Illustrations. Fifth Edition, with an Introduction by Professor Silliman. (London, 1844. H. G. Bohn). Pice 14s.

"Dr. Mantell's Wonders of Geotogy must continue to be a favourite work, equally in the geological schools, in the private study, and in the family circle. It may be read and understood by any intelligent and educated individual; its exact science, sound logic, and dignity of style, ensure its acceptance with the learned; its elegance and perspicuity, with the polite and refined; and its comprehensive brevity, with the student of the elements of Geology. It realizes, indeed, our beau-idcal of a familiar, yet dignified, philosophical style; being alike condensed and luminous, possessing a graceful and flowing eloquence, and rising, as the subject may require, into the sublime as well as the beautiful. We are not aware of the existence of any work, in any department of science, which has higher claims at once to a place in the library of a philosopher, and on the table of a refined fanilv." - American Journat of Scienre. Review of the Fourth London, and First American Edition of the Wonders of Gentogy.

"Dr. Mantell's eloquent and delightful work, the Wondcrs of Geology."Sir E. Bulwer Lytton's "Zaxosı." 
1. THE IIEDALS OF CREATION: ur, First Lessms in Geolony and in the stuly of Dromic Remenins. In 2 rols. foolsezp sro, in cloth. elegant : with coloured Plates. and sereral hundred Figures of Orranic Remains. (London: H. G. Bohn. 1:14). Price 11.1\%。

“Dt. Maxtelt's " Mads of Creation' are among the chef-doutres of the art of book-making in the best understanding of the term: we mean technically and mechanically, as well as inteilectually. The two rolumes are eleganlly bound, and. beung of a portable size. will and must take their place as the companion, not only of the geologist in his studs, but also in the teld: while they must also accompans the intelligent travellers of both s:xes, as most instructire and delightful IIentors in their journerings among rhe grand and beautitul scenes of our globe. The work is. indeed, a classic of high excellence, of great research. and formidable labour."- $t$ merican Journal of Sciencefur January. $184 \overline{5}$.

* * The "Wonders of Geology." and the "Medals of Creation." are translated into German. and copies may be obtained through the jorrign tooksthers.

VI. THOUGH'S OS A PEBBLE; or. A First Lesson in Grolom\% The seventh Edition, with elemen additional Illustrutions. In purple cloth, gilt. (Reeres Brothers, King Williamstreet, strand. $\left.1 s t b^{2}\right)$. Price 3 s.

VIl. THOEGHTS ON ANMYALCLES: or, A Glimpse of the Invisible World of Being revealed bn the Microscope. 1 rol. square Sro. with 1.2 coloured Plates, and Wood Engravings. (IIr. Murrar. London. 1stb). Price 10s. bel.

"Dr. Mantell, in the Thorghts on Amimaleules. has presented a rast deal of information on the most interesting species of Infusoria, and clothed it with that fascinating gurb. that persucsire elo wence, with which he has been ever wont to impart knowledge.-Dr. Mantell was one of the vers tirst plito sophers who shewed the fallacy of the plausible theory of the $J_{\text {pigti }}$ of Crention: "and in the work before us he has aysin adrerted to it, and. in our opinion. lias clearly exposed the error that pertades it." - Westminster Rerier. No. XC.

VIIT. A DAYS RAMBLE IS AYD ABOTT THE AXCIENT TOWX OF LEWES: illustrative of the objects of Creologieal and Antiquarian interest. 1 rol. with Plates. (H. (F. Bohn, Londun. $1 \div 10^{3}$ ). Price 5:

"A charming suide to a charminz spot, rich in picturesque scenery and historical associations of the hirhest interest._. A day ramble. which erery one who risits Brighton, and has leisure, will not fail to undertake. with so instructive and delightful a companion."-Brighton Gazette.

\section{prepariug for publiration.}

THE PHEXOMEIA OF THE IEPTOES SYSTEM : or. At Familiur Exposition of the Tature and Functions of the Berres: being the sub-tanee of a course of popular lectures. In one rolume, with numerous llustrations. 
1 
University of California

SOUTHERN REGIONAL LIBRARY FACILITY

405 Hilgard Avenue, Los Angeles, CA \$0024-1388

Return this materiat to the library

from which it was borrowed.

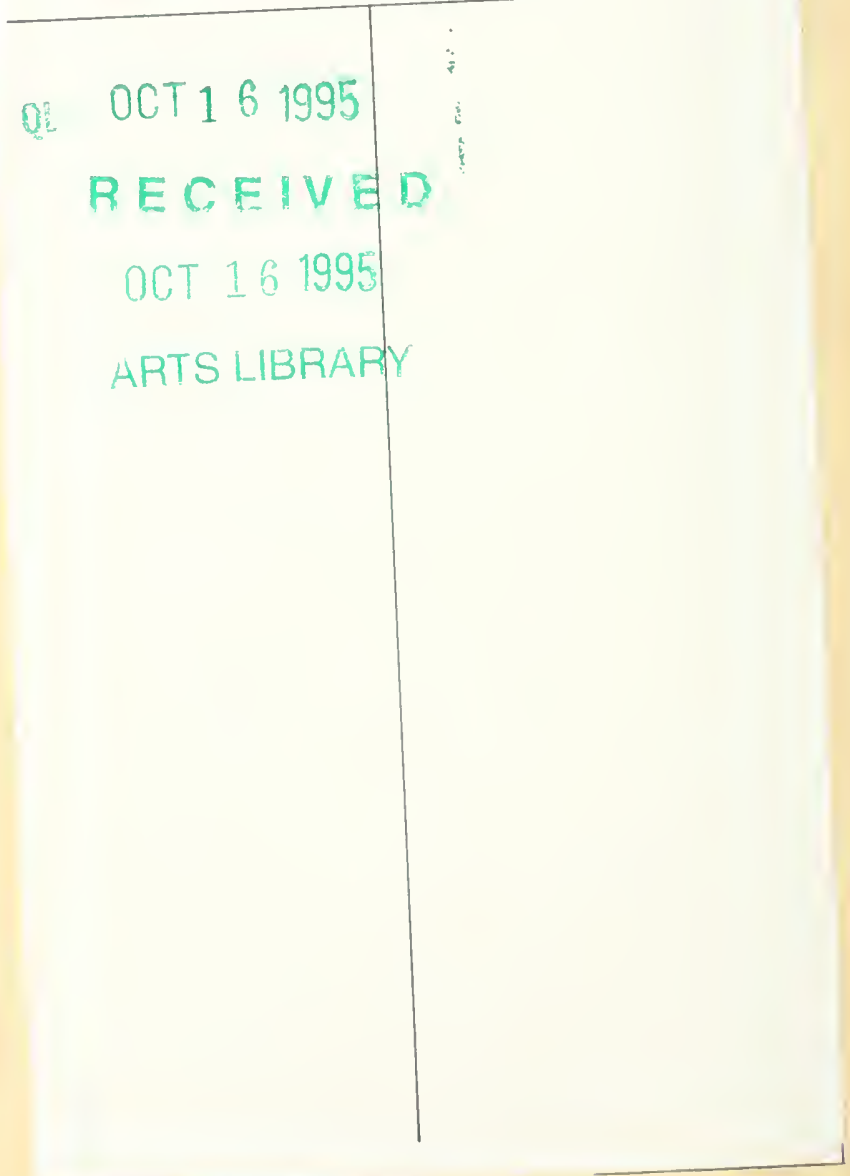


UC SOUTHERN REGIONAL LIBRARY FACILITY

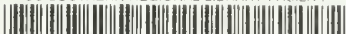




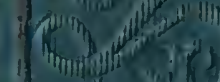

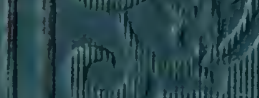

(1) ryil

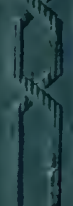

(1)
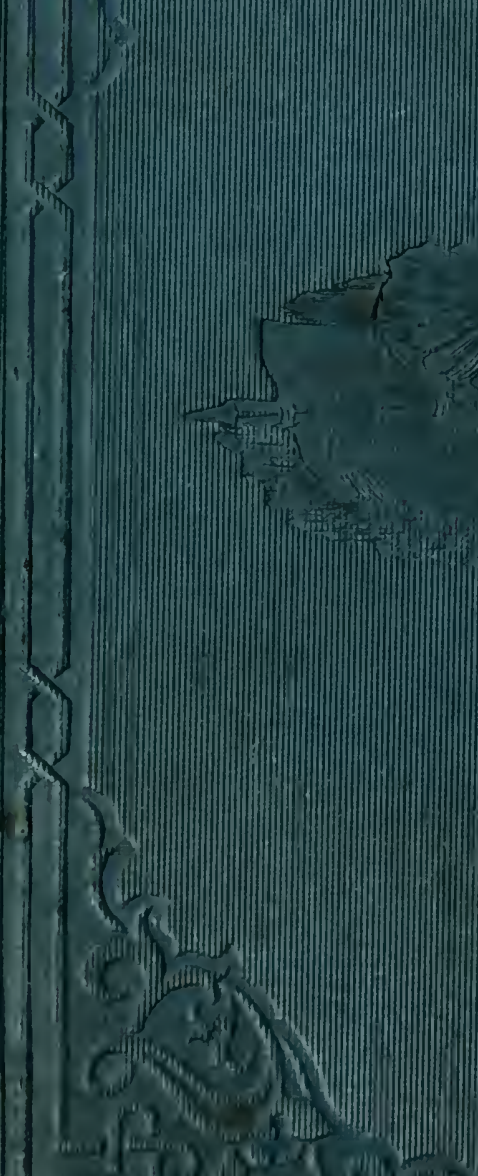

a

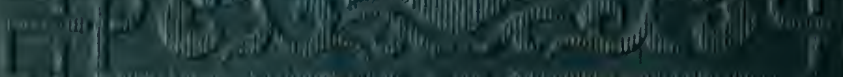

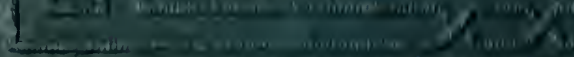

